\title{
Important Bird Areas in Macedonia: Sites of Global and European IMPORTANCE
}

\section{Mednarodno pomembna območja za ptice globalnega in evropskega pomena $\mathbf{v}$ Makedoniji}

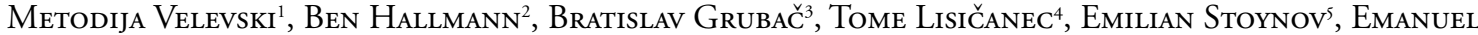 \\ LisiČAneC $^{4}$, Vasko Avukatov ${ }^{6}$, Luka Božı ${ }^{7}{ }^{7} \&$ Borut STumberger $^{8}$ \\ ${ }^{1}$ Macedonian Ecological Society, P.O. Box 162, MK-1000 Skopje, Macedonia, e-mail: velevski@mes.org.mk \\ ${ }^{2}$ GR-40008 Rapsani, Greece, e-mail: benhallmann@gmail.com \\ ${ }^{3}$ Institute for Nature Protection of Serbia, Voždova 14, RS-18000 Niš, Serbia, e-mail: grubacbratislav@gmail.com \\ ${ }^{4}$ Aquila Nature Conservation Association, Belasica 3, MK-1400 Kavadarci, Macedonia, e-mail: e.lisichanets@gmail.com \\ ${ }^{5}$ Fund for Wild Flora and Fauna, BG-2700 Blagoevgrad, P.O. Box 78, Bulgaria, e-mail: pirin@fwff.org \\ ${ }^{6}$ Macedonian Ecological Society, P.O. Box 162, MK-1000 Skopje, Macedonia, e-mail: avukatov@mes.org.mk \\ ${ }^{7}$ DOPPS - BirdLife Slovenia, Kamenškova 18, SI-2000 Maribor, Slovenia, e-mail: luka.bozic@dopps.si \\ ${ }^{8}$ EuroNatur, Konstanzer Str. 22, D-78315 Radolfzell, Germany, e-mail: stumberger@siol.net
}

Identification of the Important Bird Areas (IBAs) is an initiative implemented by BirdLife International at the global level, aiming to conserve a network of sites that are particularly important for the conservation of birds. With the changed conservation status of some species and increased information on the distribution and population sizes of birds in Macedonia in general, a revision of the IBA network was needed to update previous inventories for this country, published in 1989 and 2000. As the bird fauna of the Republic of Macedonia ranks among the least known in Europe, and as data on many species, notably passerines, are still largely missing, the inventory is mainly based on some threatened or rare birds of prey and a few other larger species, yet characteristic of the Macedonian landscape. Data used were collected in the course of different dedicated studies and projects carried out after 2000. Out of 314 species so far registered in Macedonia, 114 regularly occurring species have currently unfavourable conservation status in Europe, 84 of which breed or possibly breed in the country. Several criteria for the selection of IBAs of global (A criterion) and European importance (B criterion) developed by BirdLife International were used for sites selection, taking into consideration species of global conservation concern (A1), biome-restricted species (A3), important congregations (A4, B1) and species with an unfavourable conservation status (B2) or concentrated (B3) in Europe. Species of global conservation concern used for site identification include the Egyptian Vulture Neophron percnopterus, considered Endangered (EN) at the global level according to the latest IUCN Red List of Threatened Species, Dalmatian Pelican Pelecanus crispus and Imperial Eagle Aquila heliaca (both Vulnerable - VU), and Roller Coracias garrulus and Semicollared Flycatcher Ficedula semitorquata (both Near Threatened NT). Furthermore, species assemblages characteristic as occurring mostly or entirely within a Eurasian high-montane or Mediterranean biome are found in Macedonia. Important congregations of non-breeding waterbirds with at least $1 \%$ of global or biogeographic populations of individual species occur on all three large lakes in the country, some of them (e.g. Dalmatian Pelican, Red-crested Pochard Netta rufina) in very large numbers, surpassing the 1\% threshold by more than tenfold. In total, 25 species regularly occurring in 
the breeding season, for which the site protection approach is thought to be appropriate in Macedonia, were used for the selection of sites of European importance. Site boundaries were drawn following distinct natural features or isohypses to include breeding sites and foraging areas of triggering species, and, for Imperial Eagle and Egyptian Vulture also former breeding sites back to 1991, taking into consideration their habitat requirements, land-use and management needs. The resulting IBA list numbers 24 sites, covering $6,907 \mathrm{~km}^{2}$ or $26.9 \%$ of the entire territory of Macedonia: (1) Šar Planina Mountain, (2) River Radika Catchment, (3) Lake Ohrid, (4) Lake Prespa, (5) Demir Kapija Gorge, (6) Lake Dojran, (7) Zletovska River Valley, (8) Tikveš Region, (9) Pčinja - Petrošnica - Kriva Reka Rivers, (10) Preod - Gjugjance, (11) Osogovo Mountains, (12) Jakupica Mountain, (13) Taor Gorge, (14) Ovče Pole, (15) Topolka - Babuna - Bregalnica Rivers, (16) Gradsko - Rosoman - Negotino, (17) Lake Mantovo and Kriva Lakavica River, (18) Raec River Valley, (19) Pelagonia, (20) Mariovo, (21) Lake Tikveš, (22) Bošavija, (23) Kočani Rice Fields, and (24) Lower Vardar. With the exception of three sites occupying the highest parts of the large mountain massifs in NW and central parts of Macedonia, and the lakes Ohrid and Prespa, sites are concentrated mostly in central hilly and lowland parts of the country, comprising breeding areas of species of global conservation concern. The percentage of territory covered by the IBAs in Macedonia is relatively high compared to the total European average but comparable to several countries in SE parts of Europe. The size of separate IBAs ranges from $25 \mathrm{~km}^{2}$ (Taor Gorge) to $1,136 \mathrm{~km}^{2}$ (Pelagonia) and number of triggering species per site from one (Bošavija, Kočani Rice Fields) to 17 (Pčinja - Petrošnica - Kriva Reka Rivers). 22 sites trigger some of the criteria of global importance - three sites (Lakes Ohrid, Prespa and Dojran) meet A4 criterion, eight sites hold significant populations of species characteristic of the Mediterranean biome, while three other sites sustain significant populations characteristic of the European high-montane biome. Species of global conservation concern are included as follows: Egyptian Vulture on 13 sites, Imperial Eagle on 7, Dalmatian Pelican and Saker Falcon Falco cherrug on 2, Ferruginous Duck Aythya nyroca on 3, Roller Coracias garrulus on 10, Red-footed Falcon Falco vespertinus on 3 sites, and Semi-collared Flycatcher on 1 site. Individual triggering species for sites of European importance are represented on $2-15$ sites. The IBA network includes $80-100 \%$ of the national populations of the globally threatened species, while the coverage of other species vary between $5 \%$ and $100 \%$, being over $40 \%$ in great majority of species. Nonirrigated arable land and transitional woodland-shrub are dominant land-cover types, jointly covering $32 \%$ of the total IBA surface area. Abandonment of traditional pastoral system, resulting in decrease of the livestock numbers and overgrowing as well as trapping, poisoning and poaching, are considered the most serious threats for triggering species, particularly the Egyptian Vulture and Imperial Eagle, being classified as high on no less than 11 sites, respectively. The national legal protection of the sites is incomplete, being either only partial or with inadequate conservation measures adopted, or, many sites still lack any form of legal protection. With about $21 \%$ of the National protected area network overlapping with the IBAs, the existing protected area system is thus insufficient for conservation of most priority species. Notably underrepresented are the regions in the lower parts of the country with the highest number of species of global conservation concern.

Key words: Important Bird Areas, IBA identification, triggering species, population size, IBA criteria, species of global conservation concern, threats, Macedonia 
Ključne besede: Mednarodno pomembna območja za ptice, opredelitev IBA, kvalifikacijske vrste, velikost populacij, IBA kriteriji, vrste globalne varstvene pozornosti, dejavniki ogrožanja, Makedonija

Клучни зборови: значајни подрачја за птици, идентификација на ЗПП, видови кои ги исполнуваат критериумите за ЗПП, големина на популација, критериуми за избор на ЗПП, видови од глобален интерес за зачувување, закани, Македонија

\section{Introduction}

\subsection{IBA programme and its history in Macedonia}

Identification of the Important Bird Areas (hereinafter referred to as to "IBAs") is an initiative implemented by BirdLife International at the global level, aiming to conserve a network of sites that are particularly important for the conservation of birds, i.e. for globally threatened species, species of European conservation concern, for migratory species that congregate in high numbers, species unique for small regions (endemic species) and sites that support species assemblages highly representative of a distinct biome (НEATH \& EvANS 2000).

The first IBA inventory that covered Europe was published in 1989, and within, Macedonia was elaborated as a part of former Yugoslavia. At that time, B. Grubač compiled the data of the seven terrestrial sites, while the lakes were included on the basis of results from the mid-winter censuses in 1987 and 1988 (Grimmett \& Jones 1989). At that time, 10 IBAs were identified (Table 1, Figure 1), with a total coverage of $2,709 \mathrm{~km}^{2}$ (ca. $10 \%$ of the territory of Macedonia). This list was partially revised in 2003, when three new IBAs were proposed by E. Stoynov and accepted by BirdLife International. Two of them (Rice Plantations of Bregalnica and Zletovska Rivers, MK012 and Tikveš, MK013) were proposed on the basis of A1 criterion, supporting populations of Lesser Kestrels Falco naumanni and/or Imperial Eagles Aquila heliaca, while the third (Bistrenci Fishpond, MK011) was already within the boundaries of the previously identified IBA Demir Kapija Gorge (MK008), and was proposed under criterion Bliv (assumed bottleneck for passage of > 5000 White Storks Ciconia ciconia).

With the changed conservation status of some species (especially uplisting the Egyptian Vulture Neophron percnopterus and the Roller Coracias garrulus as Endangered and Near Threatened in 2007), and increased information on the distribution of these as well as other species (Lesser Kestrel, Imperial Eagle, etc.) in Macedonia, with a more accurate estimation of their populations, a revision of the IBA network was needed.

\subsection{Bird fauna of Macedonia}

Bird fauna of the Republic of Macedonia is among the least known in Europe, which is particularly true regarding the knowledge on distribution and quantitative population estimations, as can be witnessed by the gaps in the Atlas of European Breeding Birds (Hagemeijer \& Blair 1997) and some rather imprecise estimates (BIRDLife InTERNATIONAL 2004). Although the territory presently covered by the country has been of interest of foreign ornithologists in the period before the First and Second World Wars, and several milestone publications have been published with data from that period (GENGLER I920, Stresemann I92I, MaKaTsCH 1950), later studies (until 2000) have been mostly sporadic, short-term or localized in coverage. Notable exceptions are the works of Dimovski (1967), studying the fauna of birds in Skopje Valley in the 1955-1959 period and MicevsKi (1998 \& 2003) for Lakes Prespa (1987-1997) and Ohrid (1988-2000). Quantitative information on bird numbers and densities is also rare - in his papers, Dimovski (1967, I97IA \& I97IB) provides information on the frequencies of findings of the species he had registered and their relative abundance only. The first and so far the only quantitative study of the terrestrial bird communities has been performed on Mt Galičica in the 1985-1989 period (MicEvsKi 1990), while precise figures for the wintering populations at the three large lakes (Ohrid, Prespa and Dojran) have been gathered during several mid-winter counts (e.g. MiceVSKi I99I \& I996, FREMUTH et al. 2000).

Situation has been similar when censuses of particular species are concerned - the only complete countrywide census being the White Stork census in 1958 (Jovetić 1960). Later, somewhat less thorough in coverage, have been the works on the Golden Eagle Aquila chrysaetos in the 1980-1985 period, Lanner Falcon Falco biarmicus (1980-1994) and Long-legged Buzzard Buteo rufinus (1980-1995) (GRUBAČ 1986/87, 
M. Velevski, B. Hallmann, B. Grubač, T. Lisičanec, E. Stoynov, E. Lisičanec, V. Avukatov, L. Božič \& B. Stumberger: Important Bird Areas in Macedonia: Sites of Global and European Importance

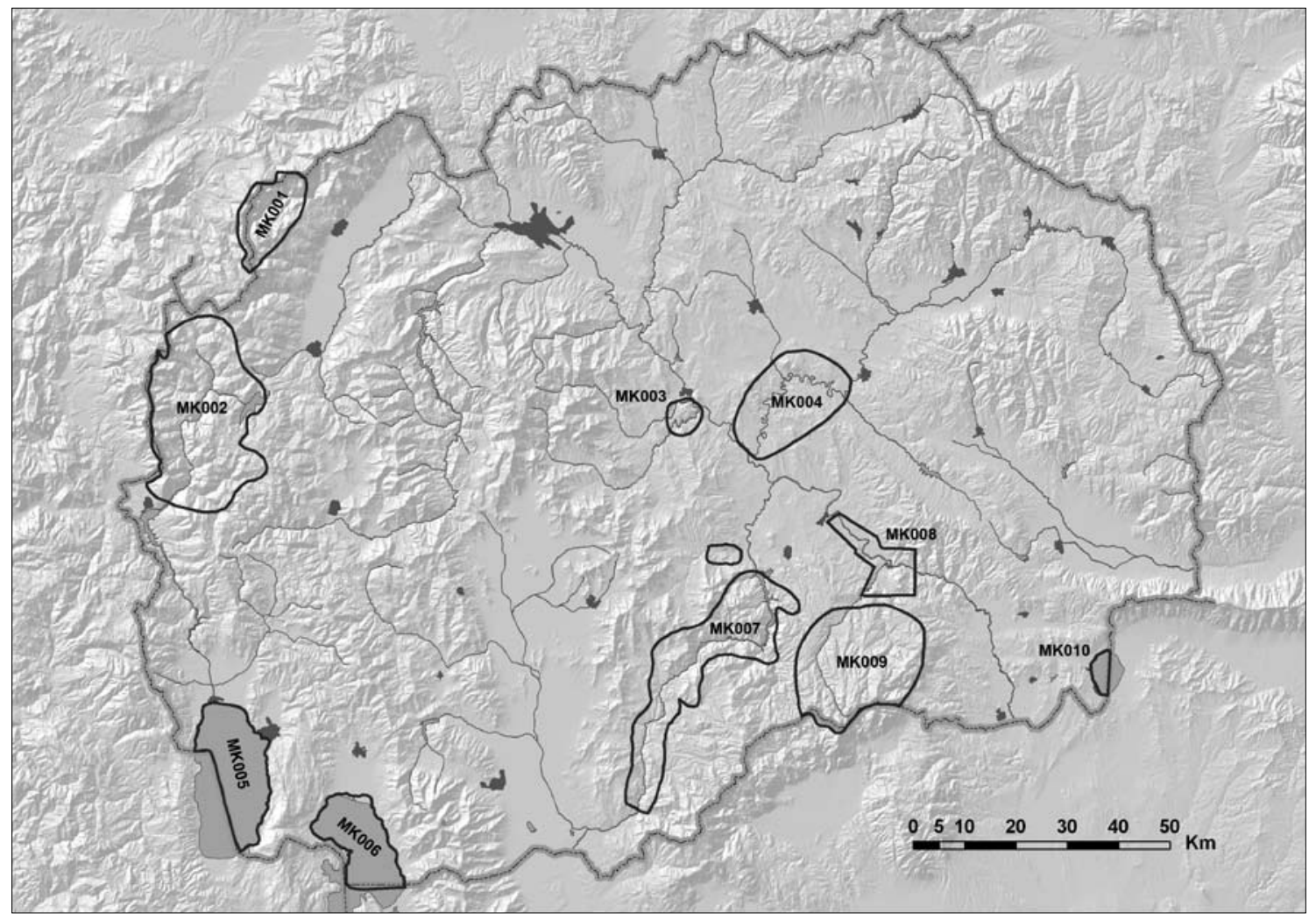

Figure 1: Map of Important Bird Areas (IBAs) in Macedonia identified in 1989 (Grimmett \& Jones 1989, HeatH \& Evans 2000)

Slika 1: Zemljevid mednarodno pomembnih območij za ptice (IBA-jev) v Makedoniji, opredeljenih leta 1989 (GRIMMETT \& JonES 1989, HeATH \& Evans 2000)

Table 1: List of IBAs in Macedonia identified during the 1989 (GriMmetT \& JonEs 1989) and 2000 inventories (HeATH \& Evans 2000). Surface areas were recalculated by the Macedonian Ecological Society since the GIS technology has become available.

Tabela 1: Seznam makedonskih IBA-jev, opredeljenih med popisi leta 1989 (Grimmett \& Jones 1989) in 2000 (Heath \& Evans 2000). Površine območij je na novo izračunalo Makedonsko ekološko društvo s pomočjo tehnologije GIS.

\begin{tabular}{|c|c|c|c|c|}
\hline $\begin{array}{l}\text { IBA code/ } \\
\text { IBA koda }\end{array}$ & Site name / Ime območja & $\begin{array}{l}\text { Centroid } \\
\text { coordinates/ } \\
\text { Koordinate } \\
\text { centroida }\end{array}$ & $\begin{array}{l}\text { Surface area/ } \\
\text { Površina }\left(\mathrm{km}^{2}\right)\end{array}$ & $\begin{array}{c}\text { Surface area } \\
\text { (recalculated)/ } \\
\text { Površina } \\
\text { (preračunana) }\left(\mathrm{km}^{2}\right)\end{array}$ \\
\hline MK001 & Shara Mountain [parts of] & $21^{\circ} \mathrm{O} 0^{\prime} \mathrm{E}, 42^{\circ} \mathrm{OO} \mathrm{O}^{\prime} \mathrm{N}$ & I2O.0 & 159.5 \\
\hline MK002 & Korab Mountain and Radika Gorge & $2 I^{\circ} 15^{\prime} \mathrm{E}, 4 \mathrm{I}^{\circ} 45^{\prime} \mathrm{N}$ & 500.0 & 651.4 \\
\hline MK003 & Babuna Gorge, Topolka Gorge, and Crn Kamen & $2 \mathrm{I}^{\circ} 45^{\prime} \mathrm{E}, 4 \mathrm{I}^{\circ} 4 \mathrm{O}^{\prime} \mathrm{N}$ & 25.0 & 38.5 \\
\hline MK004 & Bregalnica River & $22^{\circ} \mathrm{Oo} \mathrm{E}, 41^{\circ} 45^{\prime} \mathrm{N}$ & 100.0 & 306.9 \\
\hline MK005 & Lake Ohrid & $20^{\circ} 45^{\prime} \mathrm{E}, 4 \mathrm{I}^{\circ} \mathrm{O} 7^{\prime} \mathrm{N}$ & 251.0 & 246.1 \\
\hline MK006 & Lake Prespa & $2 \mathrm{I}^{\circ} \mathrm{OO} \mathrm{E}, 40^{\circ} 49^{\prime} \mathrm{N}$ & 189.2 & 196.3 \\
\hline MK007 & Crna River Gorge & $22^{\circ} \mathrm{OO} \mathrm{O}^{\prime} \mathrm{E}, 4 \mathrm{I}^{\circ} \mathrm{I} 9^{\prime} \mathrm{N}$ & 400.0 & 504.4 \\
\hline MK008 & Demir Kapija Gorge & $22^{\circ} \mathrm{I} 9^{\prime} \mathrm{E}, 41^{\circ} 19^{\prime} \mathrm{N}$ & 80.0 & I22.0 \\
\hline MK009 & Kozhuf Mountain and Boshava River & $22^{\circ} \mathrm{I} 5^{\prime} \mathrm{E}, 4 \mathrm{I}^{\circ} \mathrm{IO}{ }^{\prime} \mathrm{N}$ & 200.0 & 460.3 \\
\hline MK010 & Lake Dojran & $22^{\circ} 45^{\prime} \mathrm{E}, 4 \mathrm{I}^{\circ} \mathrm{I} 2^{\prime} \mathrm{N}$ & 42.0 & 23.8 \\
\hline \multicolumn{2}{|c|}{ Total / Skupaj } & & $1,907.2$ & $2,709.2$ \\
\hline
\end{tabular}




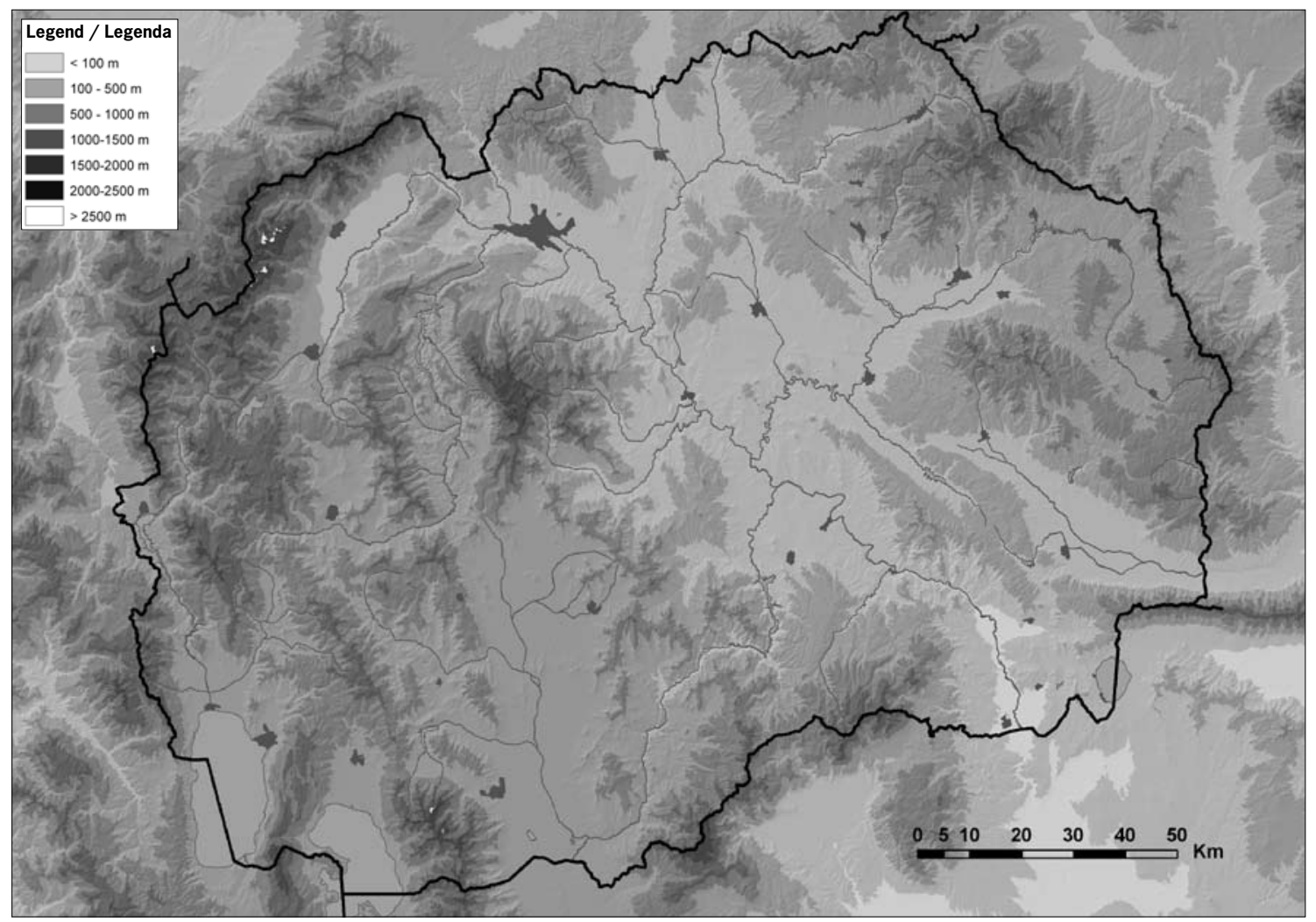

Figure 2: The relief, main waterbodies and settlements in Macedonia (from ESRI Data \& Maps for ArcView 9.1.)

Slika 2: Relief, glavna vodna telesa in naselja v Makedoniji (po ESRI Data \& Maps for ArcView 9.1.)

1994 \& 1999), Wallcreeper Tichodroma muraria (19802000) (GrubaČ 200I) and vultures (1980-1997) (e.g. GRUBAČ 1989 \& 1997).

The checklist of birds of Macedonia lists 314 species (MiceVsKi 2002/2003), but since then information on two more species (Pallid Swift Apus pallidus, VAsić et al. 2009, and Great Black-headed Gull Larus ichthyaethus, VelevsKi \& SAVEljić 20IO) has become available. Since 2009, updated checklists of birds of Macedonia and almost complete list of references for the country have been available online (VELEVSKI 2OII, VeleVSKi \& StUmberger 2OIIA \& 2OIIB).

Based on information compiled by E. Stoynov, B. Hallmann and M. Velevski, BirdLife internationaL (2004) provides quantitative estimation for all breeding bird species regularly found in the country. However, in most cases these estimations are of poor quality and with very wide margins. For the few species for which more precise information is available, the information has been largely collected in the 2000-2003 period, mostly through different conservation projects (see Chapter 2.2.). After this publication, new or updated population estimates become available for few more species - Short-toed Eagle Circaetus gallicus (Velevski \& GrubaČ 2007), Black Stork Ciconia nigra (VelevsKi et al. 2008), and the Lanner Falcon (GrubaČ \& VeleVsKi 2OIO).

114 regularly occurring species in Macedonia have currently unfavourable conservation status in Europe (SPEC 1 - nine species, SPEC 2 - 33 species, SPEC $3-72$ species), 84 of which breed or possibly breed in the country. Out of them, one species, the Egyptian Vulture, is considered Endangered (EN), three (Dalmatian Pelican Pelecanus crispus, Imperial Eagle and Saker Falcon Falco cherrug) Vulnerable (VU), and five more (Ferruginous Duck Aythya nyroca, Redfooted Falcon Falco vespertinus, Black-tailed Godwit Limosa limosa, Roller and Semicollared Flycatcher Ficedula semitorquata) Near Threatened (NT) at the global level (IUCN 20II). We have considered the Lesser Kestrel as Least Concern (LC) according to the latest assessment of its status (BirdLife InTERnational 2OII). 


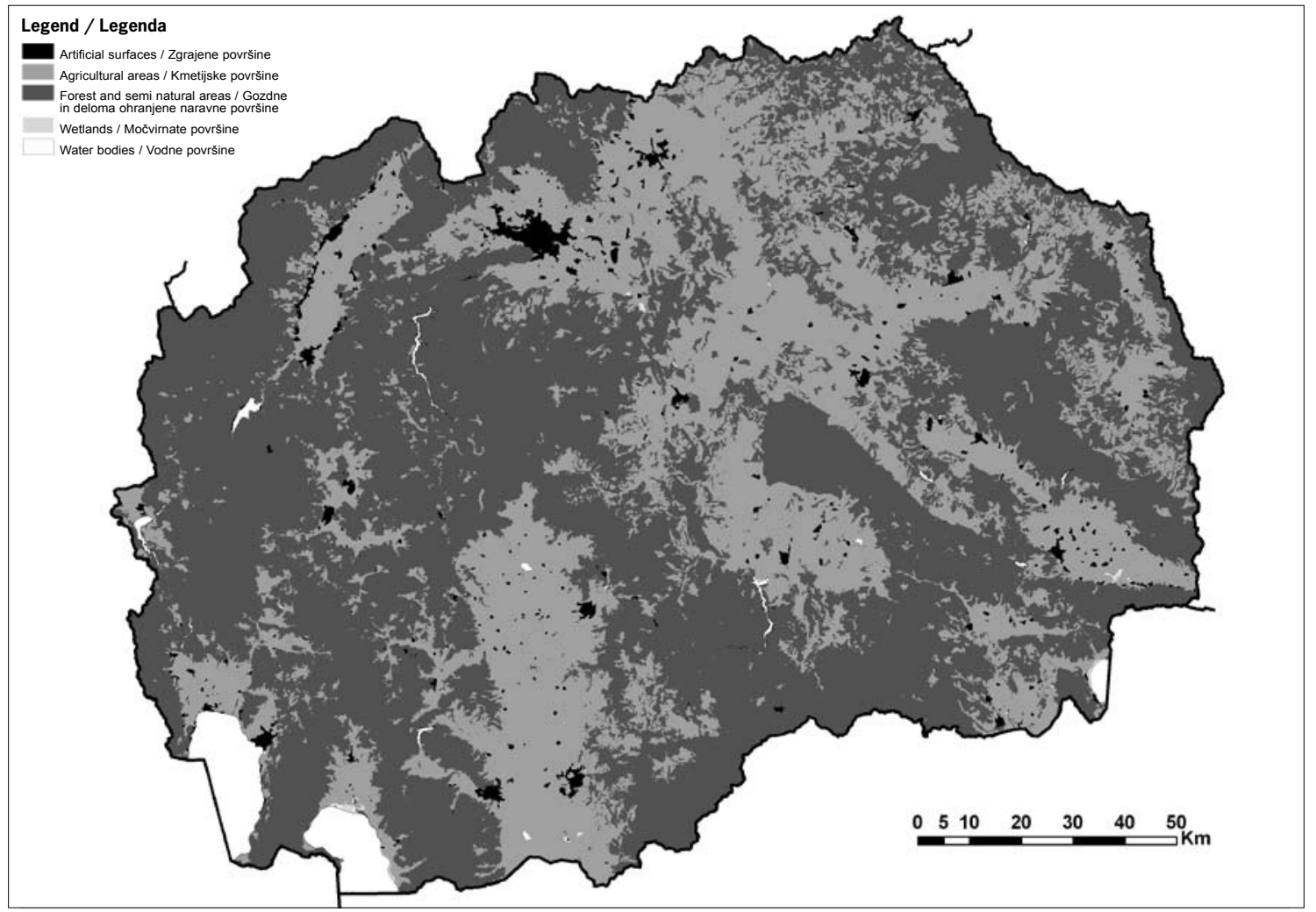

Figure 3: Main land use types, according to the CORINE Land Cover mapping, Level 1 (2006)

Slika 3: Glavni tipi rabe tal po CORINE Land Cover mapping, Level 1 (2006)

\section{Study area and methods}

\subsection{Study area}

Macedonia is small, land-locked country in the centre of the Balkan Peninsula, covering $25,713 \mathrm{~km}^{2}$ (ca. $0.25 \%$ of the European territory). The country can be roughly divided into the western mountainous region (Šar-Pindus Mountain Range, total of 141 peaks higher than 2,000 $\mathrm{m}$ a.s.l.), central lowland region (mostly the Vardar River Valley, 80-300 m a.s.l., Pelagonia Plain, $650 \mathrm{~m}$ a.s.l., Ovče Pole Plain, 350 $\mathrm{m}$ a.s.l.), and eastern mountain (Rhodopean) region (only three peaks above $2,000 \mathrm{~m}$ altitude). Large mountainous regions are also found in the central part of the country (20 peaks above $2,000 \mathrm{~m}$ altitude) and in the southern parts (12 peaks above 2,000 m altitude), with ridges forming part of the borderline with Greece. Most of the country surface $(44.1 \%)$ ranges at altitudes between 500-1,000 m a.s.l. (StATE Statistical Office of the Republic of Macedonia 2OII) (Figure 2).
Two large tectonic lakes, Ohrid (shared with Albania) and Prespa (shared with Albania and Greece), define the SW corner of the country, while the third natural lake (Lake Dojran) is located in the SE corner, on the borderline with Greece. The longest river is the Vardar $(301 \mathrm{~km})$, its longest left tributary the Bregalnica $(225 \mathrm{~km})$, and the longest right tributary the Crna Reka (207 km) (GAšEvsKI I978).

In 2010 , forests occupied $36.9 \%$ of the territory (broadleaved forests being dominant with $21.4 \%$, while mixed forests comprise $12.3 \%$ and conifer forests only 3.3\%), $19.8 \%$ were cultivated land and $23.8 \%$ pastures (State Statistical Office of the Republic of Macedonia 2OII) (Figure 3). Large portions in the central part of the country are of steppe-like character. The climate is sub-Mediterranean in the southern lowland parts (average annual temperatures $13.8-14.5^{\circ} \mathrm{C}$ ), continental throughout most of the country and mountainous above roughly $1,500 \mathrm{~m}$ a.s.l. altitude (with annual averages from -0.6 to $8.7^{\circ} \mathrm{C}$ ). The average annual precipitation is $742 \mathrm{~mm}$, ranging from $471 \mathrm{~mm}$ at Ovče Pole Plain (Central Macedonia) 
Table 2: Criteria for the selection of Important Bird Areas of global and European importance (after HEATH \& EVANS 2000). Criteria denoted in bold were used for sites selection in Macedonia.

Tabela 2: Kriteriji za izbor IBA-jev globalnega in evropskega pomena (po HEATH \& Evans 2000). Kriteriji v mastnem tisku so bili uporabljeni za izbor območij v Makedoniji.

Category / Kategorija Criteria / Kriterij

A criteria - Important Bird Areas of global importance

\section{A1. Species of global conservation concern}

A2. Restricted-range species

\section{A3. Biome-restricted species}

\section{A4. Congregations}

The site regularly holds significant numbers of a globally threatened species, or other species of global conservation concern.

The site is known or thought to hold a significant component of the restrictedrange species whose breeding distributions define an Endemic Bird Area (EBA) or Secondary Area (SA).

The site is known or thought to hold a significant assemblage of the species whose distributions are largely or wholly confined to one biome.

i) The site is known or thought to hold, on a regular basis, $\geq 1 \%$ of a biogeographic population of a congregatory waterbird species.

ii) The site is known or thought to hold, on a regular basis, $\geq 1 \%$ of the global population of a congregatory seabird or terrestrial species.

iii) The site is known or thought to hold, on a regular basis, $\geq 20,000$ waterbirds or $\geq 10,000$ pairs of seabirds of one or more species.

iv) The site is known or thought to be a bottleneck site where at least 20,000 storks (Ciconiidae), raptors (Accipitriformes \& Falconiformes) or cranes (Gruidae) regularly pass during spring or autumn migration.

B criteria - Important Bird Areas of European importance

\section{B1. Congregations}

\section{B2. Species with an unfavourable conservation status in Europe}

B3. Species with a favourable conservation status in Europe i) The site is known or thought to hold $\geq 1 \%$ of a flyway or other distinct population of a waterbird species.

ii) The site is known or thought to hold $\geq 1 \%$ of a distinct population of a seabird species.

iii) The site is known or thought to hold $\geq 1 \%$ of a flyway or other distinct population of other congregatory species.

iv) The site is a 'bottleneck' site where over 5,000 storks, or over 3,000 raptors or cranes regularly pass on spring or autumn migration.

The site is one of the ' $n$ ' most important in the country for a species with an unfavourable conservation status in Europe (SPEC $2 \& 3$ ) and for which the site-protection approach is thought to be appropriate.

The site is one of the ' $n$ ' most important in the country for a species with a favourable conservation status in Europe but concentrated in Europe (non-SPEC ${ }^{\mathrm{E} *}$ ) and for which the site-protection approach is thought to be appropriate.

* Formerly referred to as SPEC 4 species but renamed to non-SPECE in BirdLife InTERNATionaL (2004)

to $1,096 \mathrm{~mm}$ at $\mathrm{Mt}$ Šar Planina (NW Macedonia) (Lazarevski i993, State Statistical Office of the Republic of Macedonia 2OII). Human population was 2,022,547 in 2002, with average density of 78.7 people $/ \mathrm{km}^{2}$ mostly concentrated in the urban centres (25\% in the capital Skopje). Currently, the population is employed mainly in industry and trade (41.5\%), while agriculture, forestry and hunting jointly contribute to the employment rate with only 3\% (State Statistical Office of the Republic of MACEDONIA 2OII). However, agriculture as a secondary profession is common in rural centres.

\subsection{Data collection}

Several different surveys and conservation projects have resulted in numerous precise distribution data and quantitative estimations for many species, that were used at identification of the IBAs in Macedonia. The present proposal is based on data mostly gathered in the 2002-2011 period, but where necessary, older information was used in order to fill in some gaps in our knowledge.

Data on mountain IBAs were collected during the research camps organised by the Biology Students' 
M. Velevski, B. Hallmann, B. Grubač, T. Lisičanec, E. Stoynov, E. Lisičanec, V. Avukatov, L. Božič \& B. Stumberger: Important Bird Areas in Macedonia: Sites of Global and European Importance

Table 3: Species of global conservation concern, registered in Macedonia until 2011 with statuses and thresholds given. Denoted in bold are species for which identification of Important Bird Areas was considered possible under the Al criterion.

Tabela 3: Vrste globalne varstvene pozornosti, zabeležene v Makedoniji do leta 2011, z njihovim statusom in populacijskimi pragovi. Z mastnim tiskom so označene vrste, za katere je bila opredelitev IBA ocenjena kot mogoča v okviru kriterija A1.

\begin{tabular}{lcll}
\hline Species / Vrsta & $\begin{array}{c}\text { IUCN } 2011 \text { Red } \\
\text { List Category/ } \\
\text { Kategorija Rdečega } \\
\text { seznama }\end{array}$ & $\begin{array}{c}\text { Status in Macedonia/ } \\
\text { Status v Makedoniji }\end{array}$ & $\begin{array}{c}\text { Threshold/ } \\
\text { Populacijski prag }\end{array}$ \\
\hline $\begin{array}{l}\text { Pelecanus crispus } \\
\text { Anser erythropus* }\end{array}$ & VU & Resident, not breeding & $\mathbf{3 0 ~ i n d . ~}$ \\
Branta ruficollis & VU & Vagrant? & 15 ind. \\
Marmaronetta angustirostris & EN & Vagrant & Regular presence \\
Aythya nyroca & VU & Extinct & 15 ind. \\
Oxyura leucocephala & NT & Resident, breeding & $\mathbf{2 0}$ pairs \\
Milvus milvus & EN & Vagrant & Regular presence \\
Neophron percnopterus & NT & Vagrant & 30 ind. \\
Aegypius monachus & EN & Migratory, breeding & Regular presence \\
Circus macrourus & NT & Extinct & 5 pairs \\
Aquila clanga & NT & Vagrant & 30 ind. \\
Aquila heliaca & VU & Vagrant & 6 ind. \\
Falco vespertinus & VU & Resident, breeding & $\mathbf{2}$ pairs \\
Falco cherrug & NT & Migratory, possible breeding & 30 ind. \\
Tetrax tetrax & VU & Probable breeding & 2 pairs \\
Otis tarda & NT & Extinct? & 60 ind. \\
Gallinago media & VU & Vagrant? & 30 ind. \\
Limosa limosa & NT & Vagrant? & 60 ind. \\
Numenius tenuirostris* & NT & Migratory & 60 ind. \\
Numenius arquata & CR & Vagrant? & 1 ind. \\
Coracias garrulus & NT & Migratory & 60 ind. \\
Acrocephalus paludicola & NT & Migratory, breeding & $\mathbf{1 0}$ pairs \\
Ficedula semitorquata & VU & Vagrant? & 30 ind. \\
\hline Spes giva & NT & Migratory, breeding & 20 pairs \\
\hline
\end{tabular}

* Species given as "possibly to be found in Macedonia as it has been found in neighbouring regions" in MatVEJEV \& VASIĆ (I973) and as such transferred in the latest checklist (MICEVSKI 2002/2003)

"?" denotes uncertain status of the species

IUCN Red List categories (only the following categories were applied): CR - Critically Endangered, E - Endangered, VU - Vulnerable, NT - Near Threatened

Research Society, particularly for Šar Planina (19951998; Kajevska et al. 1996, Velevski et al. 2002A), Mt Bistra (Velevski et al. 2003B), Pelister (VelevsKi et al. 2003A), Jakupica (1997-1999; VeLEVSKI et al. 2002B, and in 2010 during the preparation of the Multipurpose Protected Area "Jasen" management plan by UNDP United Nations Development Program and Exploring Society "Ursus speleos" from Skopje). Results from the inventory for the needs of the National Park »Mavrovo" management plan prepared by Oxfam Italia (MicevsKI 20Io) have also been considered. Still unpublished data for other high-mountain regions gathered by $\mathrm{M}$. Velevski in the 2002-2009 period during the projects implemented by the Biology Students' Research Society and the Macedonian Ecological Society were also available for the mountains of Korab, Jablanica, Kožuf, Nidže and Osogovo.

Census of the Lesser Kestrel population in Pelagonia in 2002 (B. ŠTumberger \& M. VeleVski unpubl.) resulted with estimation of the population of not only this species, but also of the White Stork (ŠTUMBERGER \& Velevski 2002), Montagu's Harrier Circus pygargus, Jackdaw Corvus monedula and Roller. At the same time, a survey of the Lesser Kestrel colonies took place in other parts of Macedonia (Lisichanets et al. 2004). With the start of the Vulture Conservation Project in Macedonia in 2003, implemented by the Macedonian Ecological Society and Aquila Nature Conservation Association (formerly Fund for Wild Flora and Fauna - Macedonia), precise data were gathered on 
Table 4: Species in Macedonia occurring mostly or entirely within a particular biome (biome-restricted species), for which IBA identification was considered appropriate under A3 criterion

Tabela 4: Vrste v Makedoniji, ki se pojavljajo večinoma ali $\checkmark$ celoti znotraj določenega bioma (na določen biom vezane vrste) in za katere je bila opredelitev IBA ocenjena kot ustrezna v okviru kriterija $A 3$

\begin{tabular}{ll}
\hline Biome / Biom & \multicolumn{1}{c}{ Species / Vrsta } \\
\hline Eurasian high-montane & Prunella collaris \\
& Tichodroma muraria \\
& Pyrrhocorax graculus \\
& Montifringilla nivalis \\
& Alectoris graeca \\
Mediterranean & Hippolais olivetorum \\
& Sylvia cantillans \\
& Sylvia melanocephala \\
& Sitta neumayer \\
& Lanius nubicus \\
& Emberiza melanocephala \\
\hline
\end{tabular}

population sizes of the Egyptian and Griffon Vultures Gyps fulvus, but data of good quality were also gathered for the Black Stork (VelevsKi et al. 2008), Lanner Falcon Falco biarmicus (Grubač \& Velevski 2OIO), Short-toed Eagle (Velevski \& Grubač 2008), Golden Eagle, Long-legged Buzzard and Eagle Owl Bubo bubo. The Imperial Eagle has also been partially covered with these surveys, with the special survey and monitoring of this species carried out by B. Hallmann, T. Lisičanec and E. Lisičanec in the 2003-2008 period. In 2010 and 2011, the Macedonian Ecological Society implemented mid-winter censuses at the three large lakes, Ohrid, Prespa and Dojran, together with several smaller sites. Hitherto no detailed surveys have been carried out for passerines, therefore quantitative population estimates for separate sites have rarely been possible.

The surveys carried out by a group of Czech ornithologists (Š́оврі́́коví et al. 2006 \& 2007) and the detailed information made available by them to the authors were of significant value in improving the estimation of populations and delineation of the boundaries of some sites. Finally, a census of White Stork was carried out in parts of Central and Eastern Macedonia by H. Heckenroth and J.-U. Heins (The Stork Foundation) during 2010 and 2011.

As a result of the information available, compared to BirdLife International (2004), new national estimations were provided for several species (Appendix 1).

\subsection{Criteria for IBA identification}

Several criteria for the selection of IBAs have been developed by BirdLife International (HeATH \& Evans 2000). According to them, the international importance of sites can be categorized at different geographical levels: global (A criterion), European (B criterion) and European Union ( $\mathrm{C}$ criterion, used for the selection of sites under the EU Birds Directive not treated herein). Criteria for the selection of sites of global and European importance are summarized in Table 2.

The methodology for identification of the IBAs presented in Heath \& Evans (2000) was followed. The latest assessment of the Red List category (IUCN 20II) was used for the selection of species of global conservation concern. SPEC categories were after BirdLifE InTERNATIONAL (2004), together with estimation of the European populations, except for the Lesser Kestrel, Roller, Egyptian Vulture and Semicollared Flycatcher, where the data from the updated species action plans were used (IÑ IGO et al. 2008, Kovacs et al. 2008, GeORgIEv \& IANKov 20IO, IÑIgO $\&$ BAROV 20IO). The following criteria were used for selection of IBAs in Macedonia:

\section{(1) A criteria: Important Bird Areas of global importance}

For identification of the sites of global importance under the criteria $\mathrm{A} 1$ and $\mathrm{A} 3$, lists of species potentially fulfilling these criteria were developed (Tables $3 \&$ 4 ), and only the species regularly occurring in the country were taken into consideration.

Under the A1 criterion, sites holding sufficient numbers of globally threatened (IUCN Red List categories CR, EN and VU) and Near Threatened (NT) species are selected. For Critically Endangered (CR) and Endangered (EN) species, their regular presence alone merits the site identification, while others should meet corresponding thresholds (Table 3) and be regularly present at a site. Thresholds were used after Heath \& Evans (2000) updated with information from BirdLife International (I. BURFIELD pers. comm.).

Under the A3 criterion, representative sites, holding rich assemblages of biome-restricted species and reflecting the distribution of biome in the country are selected. Out of five biomes treated under this criterion in Europe, two occur in Macedonia - the Eurasian high-montane biome (with 10 characteristic bird species in Europe) and Mediterranean biome (21 characteristic species). The list of biome-restricted species occurring in Macedonia is given in Table 4. 
M. Velevski, B. Hallmann, B. Grubač, T. Lisičanec, E. Stoynov, E. Lisičanec, V. Avukatov, L. Božič \& B. Stumberger: Important Bird Areas in Macedonia: Sites of Global and European Importance

Table 5: Population estimates of non-breeding congregatory waterbirds in Macedonia in the 1988-2011 period. Species denoted in bold meet $1 \%$ threshold for criteria A4i and Bli on at least one site.

Tabela 5: Ocene populacij negnezdečih vodnih ptic, ki se združujejo v jate, v Makedoniji v obdobju 1988-2011. Vrste, prikazane v mastnem tisku, zadovoljujejo enoodstotni populacijski prag za kriterija A4i in B1i v vsaj enem območju.

\begin{tabular}{|c|c|c|c|c|c|c|}
\hline \multirow[t]{2}{*}{$\begin{array}{l}\text { Species/ } \\
\text { Vrsta }\end{array}$} & \multicolumn{2}{|c|}{$\begin{array}{c}\text { Non-breeding } \\
\text { population MK } \\
\text { (ind.)/ } \\
\text { Negnezdeča } \\
\text { popul. MK (os.) }\end{array}$} & \multirow[t]{2}{*}{$\begin{array}{l}\text { Waterbird population/ } \\
\text { Populacija vodnih ptic }\end{array}$} & \multicolumn{2}{|c|}{$\begin{array}{l}\text { Percentage of } \\
\text { population in } \\
\text { MK / Odstotek } \\
\text { populacije v } \\
\text { MK (\%) }\end{array}$} & \multirow[t]{2}{*}{$\begin{array}{c}1 \% \\
\text { treshold/ } \\
\text { popul. } \\
\text { prag }\end{array}$} \\
\hline & $\min$ & $\max$ & & $\min$ & $\max$ & \\
\hline Gavia arctica & 5 & 50 & arctica & $<$ O.I & $<$ O.I & 3,750 \\
\hline Tachybaptus ruficollis & IOO & 900 & ruficollis & $<$ O.I & 0.2 & 4,000 \\
\hline Podiceps cristatus & 400 & 5,700 & Black Sea, Mediterranean & O.I & 0.8 & 7,250 \\
\hline Podiceps nigricollis & 100 & 5,700 & Europe, N Africa & $<0$. I & 2.7 & 2,200 \\
\hline Phalacrocorax carbo sinensis & IOO & $\mathrm{I}, 200$ & Black Sea, Mediterranean & $<$ O.I & 0.3 & 4,000 \\
\hline Phalacrocorax pygmeus & 20 & 3,500 & SE Europe, Turkey & $<$ O.I & 5.0 & 700 \\
\hline Pelecanus onocrotalus* & 200 & 550 & Europe, W Asia & I.o & 1.7 & 270 \\
\hline Pelecanus crispus* & 300 & I,000 & Black Sea, Mediterranean & 6.0 & 20.8 & 45 \\
\hline Cygnus olor & IO & 160 & Black Sea & $<$ O.I & 0.4 & 450 \\
\hline Anas penelope & 65 & 940 & Black Sea, Mediterranean & $<$ O.I & 0.3 & 3,000 \\
\hline Anas strepera & IO & IOO & Central Europe, Black Sea, Mediterranean & $<$ O.I & O.I & $\mathrm{I}, \mathrm{IOO}$ \\
\hline Anas crecca & 650 & 6,500 & Black Sea, Mediterranean & O.I & 0.6 & 10,600 \\
\hline Anas platyrhynchos & 200 & 5,100 & Black Sea, E Mediterranean & $<$ O.I & 0.3 & 20,000 \\
\hline Anas acuta & 25 & IOO & Black Sea, Mediterranean, W Africa & $<$ O.I & $<$ O.I & 7,500 \\
\hline Anas clypeata & 15 & IOO & Black Sea, Mediterranean, W Africa & $<$ O.I & $<$ O.I & 4,500 \\
\hline Netta rufina & 550 & 7,000 & Black Sea, E Mediterranean & $\mathbf{I . 9}$ & $23 \cdot 7$ & 320 \\
\hline Aythya ferina & 300 & 10,500 & Central Europe, Black Sea, Mediterranean & $<$ O.I & I.I & IO,००० \\
\hline Aythya nyroca & 5 & IO & E Europe, E Mediterranean, Black Sea & $<$ O.I & $<$ O.I & 450 \\
\hline Aythya fuligula & 300 & 18,500 & Central Europe, Black Sea, Mediterranean & $<$ O.I & 2.6 & 7,000 \\
\hline Bucephala clangula & 20 & 500 & SE Europe, Adriatic & $<$ O.I & 0.3 & 2,000 \\
\hline Mergellus albellus & 2 & 35 & Black Sea, E Mediterranean & $<$ O.I & O.I & 350 \\
\hline Mergus merganser & 2 & 22 & Balkans & 2.8 & 3I.I & \\
\hline Fulica atra & 20,000 & 8I,000 & Black Sea, Mediterranean & 0.8 & 3.2 & 20,000 \\
\hline Larus ridibundus & IOO & $\mathrm{I}, 600$ & E Europe & $<$ O.I & O.I & I3,OOO \\
\hline Larus michahellis / cachinnans & 20 & $\mathrm{I}, 400$ & michahellis / cachinnans & $<$ O.I & 0.2 & 20,000 \\
\hline
\end{tabular}

Wintering populations, except ${ }^{*}$ non-breeding population occurring in the reproductive period of the species. Waterbird population after WETLANDS INTERNATIONAL (2006).

For category A4, the site must meet at least one of the criteria given in Table 2. However, Birdlife International now treats $\mathrm{A} 4 \mathrm{i}$ as $1 \%$ of the total global population (I. BuRFIELD pers. comm.). We have used data from the winter waterbird censuses (Micevski I99i, Micevski 1996, Micevski \& Schneider 1997, Micevski 1998, Fremuth et al. 2004, Wetlands International in litt.), unpublished results of the Macedonian Ecological Society from 2010 and 2011, and estimates of their respective global populations (WeTLANDS INTERNATIONAL 2006) for site identification under the A4i criterion.
We have considered species qualifying under A4i only if it has met $1 \%$ of its total global population in at least one third of the mid-winter counts. Total numbers of waterbirds registered during the winter counts were used to test sites against A4iii criterion ( $\geq 20,000$ waterbirds on regular basis).

\section{(2) B criteria: Important Bird Areas of European importance}

Several criteria for the identification of sites of European importance were considered suitable for Macedonia.

We have considered species qualifying under 


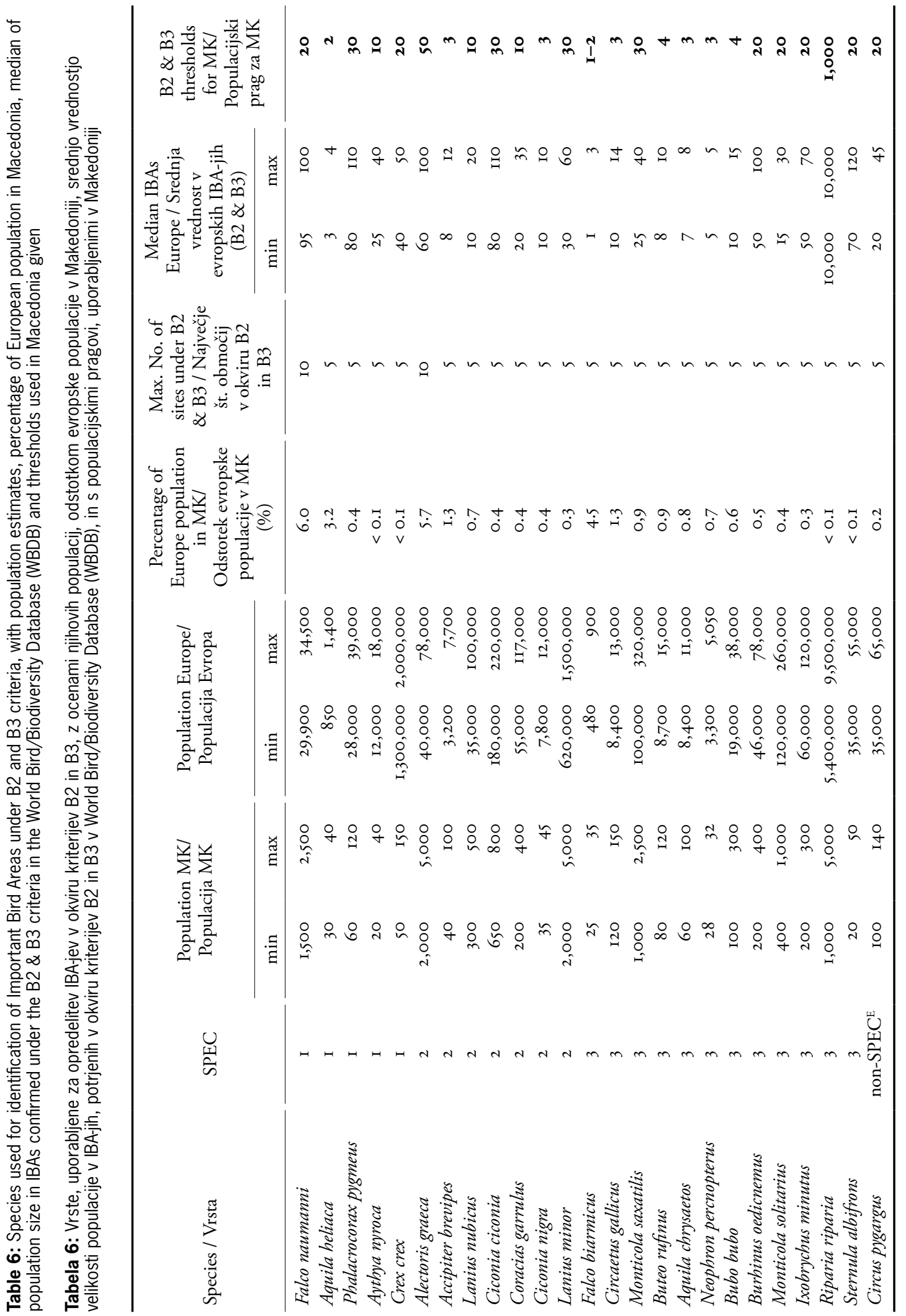


M. Velevski, B. Hallmann, B. Grubač, T. Lisičanec, E. Stoynov, E. Lisičanec, V. Avukatov, L. Božič \& B. Stumberger: Important Bird Areas in Macedonia: Sites of Global and European Importance

\section{Nadaljevanje tabele $6 /$ continuation of Table 6}

Population estimates refer to breeding pairs after BirdLife InTERnATIONAL (2004), except Falco naumanni, Coracias garrulus, Neophron percnopterus and Ficedula semitorquata, where data from the action plans were used (Iñigo et al. 2008, Kovacs et al. 2008, GeOrgiev \& IANKov 20IO, Iñigo \& Barov 20io) SPEC - species of European conservation concern (SPEC 1 - European species of global conservation concern in Europe, i.e. classified as Critically Endangered, Endangered, Vulnerable, Near Threatened or Data Deficient under the IUCN Red List Criteria at a global level; SPEC 2 - species whose global populations are concentrated in Europe, and which have an Unfavourable conservation status in Europe; SPEC 3 - species whose global populations are not concentrated in Europe, but which have an Unfavourable conservation status in Europe; non-SPEC ${ }^{\mathrm{E}}$ - species whose global populations are concentrated in Europe but which have a Favourable conservation status in Europe) (BIrDLife INTERNATIONAL 2004)

B1i only if it has met $1 \%$ threshold for the individual waterbird flyway population (WETLANDS INTERNATIONAL 2006) in at least one third of the mid-winter counts (Table 5).

For identification of the sites that meet B2 and B3 criteria, the following steps were followed for selection of the triggering species:

- to have unfavourable conservation status in

Europe (SPEC 1, $2 \& 3$ ) - B2, or favourable conservation status, but with more than $50 \%$ of their global range lying in Europe (non-SPEC ${ }^{\mathrm{E}}$ B3 (BirdLife InTERNATIONAL 2004);

- a site protection approach is thought to be appropriate in Macedonia;

- to have national population of at least $0.5 \%$ of the European population or it was possible to identify IBAs according to Heath \& Evans (2000) who state, "Also, for countries which hold less than $1 \%$ of the European population of a given species, or for countries which comprise less than $1 \%$ of the total land area of Europe (i.e. less than ca. $100,000 \mathrm{~km}^{2}$ ), sites may still be selected under this criterion if they support similar numbers of the species as sites in other countries, which meet this criterion in a standard fashion". Instead of minimal populations, we applied geometric means of the estimations due to low quality of the estimation data provided in BirdLife International (2004). A threshold of $1 \%$ of the national population size was used to identify the most important sites for these species, but for species the minimal population size of which has been estimated at under or close to 100 pairs, like Levant Sparrowhawk Accipiter brevipes, Black Stork, Lanner Falcon, Short-toed Eagle, Long-legged Buzzard and Eagle Owl, direct recommendations from BirdLife International, based on the data from already confirmed IBAs in the World Bird/Biodiversity Database (WBDB), were followed (I. BuRfieLD pers. comm.). For species where national population was up to $5 \%$ of European population, maximum of five IBAs were proposed, while for species where national population was $5-10 \%$ of European population, 10 IBAs at the most were proposed. Species used for identification of IBAs under these criteria are given in Table 6. Full list of species considered under $\mathrm{B} 2$ and $\mathrm{B} 3$ criteria is given in Appendix 1.

\subsection{Other important bird species}

Species of global conservation concern found with populations not sufficient to meet A1 criterion, SPEC 2 and SPEC 3 species that have populations that would otherwise meet B2 criterion, but for which maximal number of sites (5 or 10) has already been proposed, or do not meet the threshold set, but are still considered to be of national importance for conservation due to their small populations or negative population trends have been identified as 'other important species' and are also presented in the site overviews. Also, species with significant percentages of their national populations (roughly $>50 \%$ ) found at only a few sites were included in this group.

\subsection{Boundaries, land cover and threats}

For delineation of the boundaries, ArcView 9.1 (ESRI 2005) was used. All known nesting locations of solitary pairs and colonies of the triggering species, with number of pairs in colonies were overlaid on $1: 25,000$ scale topographic maps used as background layer. Boundaries were drawn to include breeding sites, foraging areas, and, for Imperial Eagle and Egyptian Vulture only, former breeding sites (back to 1991) as much as possible and reasonable. Also, habitat requirements of the triggering species, land-use and management needs were considered. All boundaries were drawn following natural distinct features (ridges, valleys, roads), or, where this was impossible, isohypses were followed. The chapters "Site description" (see 3.2. Overview of sites) include descriptions of the borders in a manner that they can be easily identified on topographic $1: 25,000$ scale maps. Geographical and geological characteristics are presented, after KOLČAKOVSKI (2004 \& 2008). 


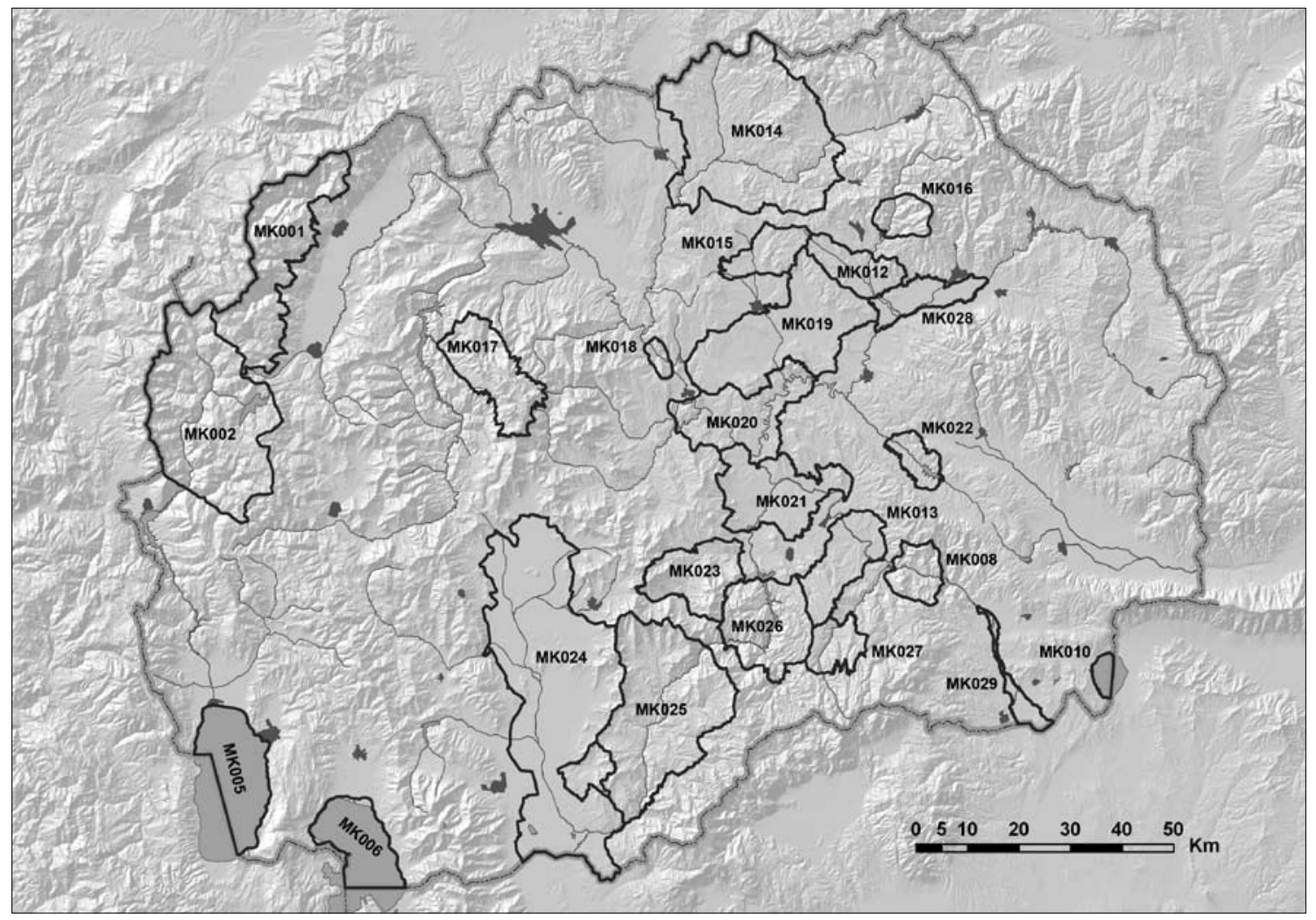

Figure 4: Map of the IBAs identified in Macedonia

Slika 4: Zemljevid IBA-jev, opredeljenih v Makedoniji

Using data from CORINE Land Cover (EEA 2006), the percentage of land cover types according to the CORINE Land Cover, Level 3 was calculated for each site. However, only land cover types exceeding 5\% of the total surface area of the site are presented in the tables, others being merged under the label "Others". The exceptions are small-scale land cover types of particular importance for the triggering species. The overall classification of the major CORINE land cover types found within IBA boundaries is given in Appendix 2.

Threats were identified on the basis of threat list provided in the national Emerald Database (see Appendix 3). To quantify the importance of threats with regard to their actual or potential impact, the scoring method after Heath \& Evans (2000) was used:

(1) Effect of threat on the habitat (for habitatrelated threats)

- destruction

- rapid deterioration

- slow deterioration (scores)
(1) Expected/measured effect on threatened species (for bird-related threats)

- majority of critical species are affected 3

- some critical species are affected

- only non-critical species are affected

(2) Spatial scale of the threat in relation to the IBA

- affects the IBA as a whole

- affects a large part of the IBA but not critical sites for threatened species or a relatively small part of the IBA, which is important for threatened species

- affects a relatively small part of the IBA with no crucial site for threatened species

(3) Realization of the threat

- threat already exists

- threat is planned with realization

expected in short term

- threat is planned with realization

expected in longer term

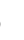

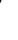


M. Velevski, B. Hallmann, B. Grubač, T. Lisičanec, E. Stoynov, E. Lisičanec, V. Avukatov, L. Božič \& B. Stumberger: Important Bird Areas in Macedonia: Sites of Global and European Importance

Table 7: List of IBAs identified in Macedonia with criteria used.

Tabela 7: Seznam IBA-jev, opredeljenih v Makedoniji z uporabljenimi kriteriji

\begin{tabular}{|c|c|c|c|}
\hline $\begin{array}{l}\text { IBA code/ } \\
\text { IBA koda }\end{array}$ & $\begin{array}{l}\text { Site name (Macedonian)/ } \\
\text { Ime območja (makedonsko) }\end{array}$ & $\begin{array}{l}\text { Site name (English)/ } \\
\text { Ime območja (angleško) }\end{array}$ & $\begin{array}{l}\text { IBA Criteria/ } \\
\text { IBA kriteriji }\end{array}$ \\
\hline MK001 & Šar Planina & Šar Planina Mountain & A3, B2 \\
\hline MK002 & Sliv na reka Radika & Radika River Catchment & A3, B2 \\
\hline MK005 & Ohridsko Ezero & Lake Ohrid & A4iii, B1i, B2 \\
\hline MK006 & Prespansko Ezero & Lake Prespa & A1, A4i, B1i, B2 \\
\hline MK008 & Demirkapiska Klisura & Demir Kapija Gorge & $\mathrm{A} 1, \mathrm{~A} 3, \mathrm{~B} 2$ \\
\hline MK010 & Dojransko Ezero & Lake Dojran & A1, A4i, B1i, B2 \\
\hline MK012 & Dolina na Zletovska Reka & Zletovska River Valley & $\mathrm{A} 1, \mathrm{~B} 2$ \\
\hline MK013 & Tikveški region & Tikveš Region & A1, B2 \\
\hline MK014 & Reka Pčinja - reka Petrošnica - Kriva Reka & Pčinja - Petrošnica - Kriva Reka Rivers & $\mathrm{A} 1, \mathrm{~A} 3, \mathrm{~B} 2$ \\
\hline MK015 & Preod - Gjugjance & Preod - Gjugjance & $\mathrm{A} 1, \mathrm{~B} 2$ \\
\hline MK016 & Osogovski Planini & Osogovo Mountains & $\mathrm{A} 1, \mathrm{~B} 2$ \\
\hline MK017 & Jakupica & Jakupica Mountain & $\mathrm{A} 3, \mathrm{~B} 2$ \\
\hline MK018 & Taorska Klisura & Taor Gorge & $\mathrm{A} 1, \mathrm{~A} 3$ \\
\hline MK019 & Ovče Pole & Ovče Pole & $\mathrm{A} 1, \mathrm{~B} 2$ \\
\hline MK020 & Reka Topolka - reka Babuna - reka Bregalnica & Topolka - Babuna - Bregalnica Rivers & $\mathrm{A} 1, \mathrm{~A} 3, \mathrm{~B} 2$ \\
\hline MK021 & Gradsko - Rosoman - Negotino & Gradsko - Rosoman - Negotino & $\mathrm{A} 1, \mathrm{~A} 3, \mathrm{~B} 2$ \\
\hline MK022 & Mantovsko Ezero i reka Kriva Lakavica & Lake Mantovo and Kriva Lakavica River & $\mathrm{A} 1, \mathrm{~B} 2$ \\
\hline MK023 & Dolina na reka Raec & Raec River Valley & $\mathrm{A} 1, \mathrm{~A} 3, \mathrm{~B} 2$ \\
\hline MK024 & Pelagonija & Pelagonia & A1, A4ii, B1iii, B2, B3 \\
\hline MK025 & Mariovo & Mariovo & $\mathrm{A} 1, \mathrm{~A} 3, \mathrm{~B} 2$ \\
\hline MK026 & Tikveško Ezero & Lake Tikveš & $\mathrm{A} 1, \mathrm{~A} 3, \mathrm{~B} 2$ \\
\hline MK027 & Bošavija & Bošavija & A1 \\
\hline MK028 & Kočanski orizovi polinja & Kočani Rice Fields & B2 \\
\hline MK029 & Dolen tek na reka Vardar & Lower Vardar & B2 \\
\hline
\end{tabular}

The combined level of the threat is calculated by summing up the values (1), (2) and (3). Threats can be classified into three groups according to the magnitude of the impact: high impact (scores 8 and 9), medium impact (scores 6 and 7) and low impact (scores 3, 4 and 5). Detailed calculation of threat scores is given in Appendix 4.

\subsection{Data presentation}

Species data are presented in tables. The first column delineates the species' Latin name, while the second column presents the information on the status of species and season in which species meets IBA criteria after Heath \& Evans (2000) ( $\mathrm{R}=$ breeding resident, $\mathrm{B}=$ breeding visitor, $\mathrm{W}=$ wintering visitor, $\mathrm{P}=$ passage visitor, $\mathrm{N}=$ non-breeding visitor, and $\mathrm{U}=$ unknown). In the column "Year", the year of population estimation is given. When period is given, it is related to species population size change or fluctuation in the given period. Under "Population", estimation of the population size in pairs (unless stated in individuals) is given. In some cases, where no sufficient data existed to estimate the population size, qualitative abundance estimates according to Heath \& Evans (2000) have been presented ("abundant" = encountered in large numbers in preferred habitat, "common" = encountered singly or in small numbers in preferred habitat, "frequent" = often, but not always, met in the preferred habitat, "uncommon" = encountered sporadically in preferred habitat, "rare" = rarely seen, usually less than 10 records, and "unknown" = not possible to assess abundance). Quality of the estimation is presented in the column "Acc." (Accuracy), where A = reliable, $\mathrm{B}=$ incomplete, $\mathrm{C}=$ poor (after Heath \& Evans 2000). No data quality is given if population figures are not available. In the last column "Criteria", one or more criteria that the species meet at a particular site are given, with "?" indicating that the species probably meets the given criterion, but further research is needed to justify it. In the same column, "N" is used when a population is considered to be of 
national importance. Species meeting at least one IBA criterion on given site are denoted in bold.

\section{Results}

\subsection{Sites}

The new IBA proposal lists 24 sites (Table 7, Figure 4), covering $6,907.35 \mathrm{~km}^{2}$ or $26.9 \%$ of the territory of Macedonia (Table 7). With the exception of the mountain ranges in the NE and central parts of Macedonia, and Lakes Ohrid and Prespa, sites are distributed mostly in the central lowland parts of the country (Pčinja-Vardar Valleys and Pelagonia Plain). The size of separate IBAs ranges from $25 \mathrm{~km}^{2}$ (Taor Gorge) to $1,136 \mathrm{~km}^{2}$ (Pelagonia), with relative coverage of the country between 0.1 and $4.4 \%$. The number of triggering species per site ranges from one (Bošavija, Kočani Rice Fields) to 17 (Pčinja - Petrošnica - Kriva Reka Rivers). Some of these localities are partially or entirely under protection of the national legislation (Ohrid Lake, Prespa Lake, Dojran Lake, Tikveš Lake, Demir Kapija and Radika River Catchment), while others are partially or entirely included in the national Emerald Network (Osogovo Mt, Topolka - Babuna - Bregalnica Rivers, Taor Gorge, Jakupica Mt, Šar Planina Mt, Ovče Pole, Pelagonia and Mariovo). Nonirrigated arable land and transitional woodland-shrub are dominant land-cover types, covering 1,171.5 $\mathrm{km}^{2}$ (17 sites), and $1,017 \mathrm{~km}^{2}$ (23 sites) in total, respectively. The total coverage of agricultural areas is $3,282 \mathrm{~km}^{2}(47.5 \%)$ of IBAs.

\subsection{Overview of the sites}

\subsection{1. Šar Planina Mountain}

\section{General information}

Name in English: Šar Planina Mountain

Name in Macedonian: Šar Planina (Шар Планина)

IBA code: $\mathrm{MK} 001$

Criteria: A3, B2

Area: 43,418 ha

Central coordinates: $20^{\circ} 49^{\prime} 18.96^{\prime \prime} \mathrm{E}, 41^{\circ} 57^{\prime} 11.34{ }^{\prime \prime} \mathrm{N}$

Altitude: $640-2,748 \mathrm{~m}$ a.s.l.

Administrative region(s): Tearce, Tetovo, Bogovinje, Vrapčište, Gostivar, Rostuše-Mavrovo

\section{Site description}

The site occupies southern and central parts of Šar Planina Mt, which is one of the largest mountains in Macedonia, situated in its NW corner, and whose

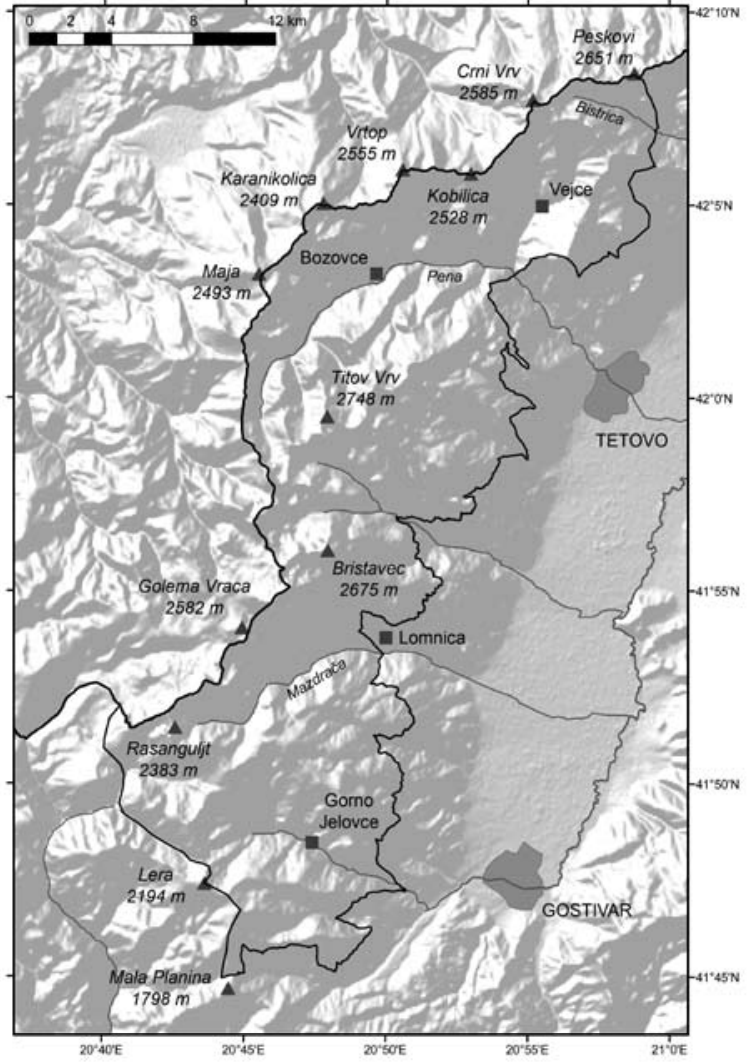

Figure 5: Map of the IBA Šar Planina Mountain with its main features depicted

Slika 5: Zemljevid IBA Šar Planina z glavnimi značilnostmi območja

ridge forms the borderline with Kosovo. The lower boundary of the site runs at ca. 1,200 $\mathrm{m}$ a.s.l, but at places descends to as low as $640 \mathrm{~m}$ a.s.l. To the south, the boundary follows the Ćafa e Kadis and Ađina Reka Rivers and the ridge between the peaks of Lera (2,194 $\mathrm{m}$ a.s.l.), Morava (2,147 $\mathrm{m}$ a.s.l.) and Mala Planina (1,798 $\mathrm{m}$ a.s.l.). To the NW, it reaches the peak of Peskovi (2,651 m a.s.l.) and the Bistrica River Valley, leaving ca. $12 \mathrm{~km}$ of the mountain ridge (not of high importance for the conservation of triggering species) outside the site. Compared to the boundaries from 1989 (site YU048, Grimmett \& Jones 1989) and 2000 (site MK001, Heath \& Evans 2000), the site coverage has expanded almost three times. The site adjoins the IBA "Šar-planina" (RS035) in Kosovo, Puzović et al. (2009).

Mountainous relief dominates, with the highest parts of the mountain (Titov Vrv 2,748 m a.s.l., Mal Turčin 2,702 m a.s.l., Kobilica 2,528 m a.s.l. etc.) well above 2,500 m altitude. Quite characteristic is the Pena River 
M. Velevski, B. Hallmann, B. Grubač, T. Lisičanec, E. Stoynov, E. Lisičanec, V. Avukatov, L. Božič \& B. Stumberger: Important Bird Areas in Macedonia: Sites of Global and European Importance

Table 8: List of triggering and other important bird species in the IBA Šar Planina Mountain

Tabela 8: Seznam kvalifikacijskih in drugih pomembnih vrst ptic v IBA Šar planina

\begin{tabular}{|c|c|c|c|c|c|}
\hline $\begin{array}{l}\text { Species/ } \\
\text { Vrsta }\end{array}$ & $\begin{array}{l}\text { Season/ } \\
\text { Sezona }\end{array}$ & $\begin{array}{l}\text { Year/ } \\
\text { Leto }\end{array}$ & $\begin{array}{l}\text { Population/ } \\
\text { Populacija }\end{array}$ & $\begin{array}{l}\text { Acc./ } \\
\text { Zan. }\end{array}$ & $\begin{array}{l}\text { Criteria/ } \\
\text { Kriteriji }\end{array}$ \\
\hline Prunella collaris & B & 2004 & $20-40$ & C & A3 \\
\hline Tichodroma muraria & B & 2004 & 5-10 & $\mathrm{C}$ & A3 \\
\hline Pyrrbocorax graculus & B & 2005 & $100-200$ & C & A3 \\
\hline Montifringilla nivalis & B & 2004 & $10-30$ & C & A3 \\
\hline Aquila chrysaetos & $\mathbf{R}$ & 2003 & $3-4$ & B & $\mathrm{B} 2$ \\
\hline Alectoris graeca & $\mathbf{R}$ & 2009 & $50-150$ & C & $\mathrm{B} 2$ \\
\hline Crex crex & B & 2010 & $20-50$ & C & $\mathrm{B} 2$ \\
\hline Bubo bubo & $\mathbf{R}$ & 2007 & $5-10$ & C & $\mathrm{B} 2$ \\
\hline Pyrrhocorax pyrrhocorax & $\mathrm{B}$ & & Common & & $\mathrm{B} 2 ?$ \\
\hline Gyps fulvus & $\mathrm{N}$ & 2009 & I-IO ind. & $\mathrm{C}$ & $\mathrm{N}$ \\
\hline Falco peregrinus & $\mathrm{R}$ & 2009 & $2-5$ & $\mathrm{C}$ & $\mathrm{N}$ \\
\hline Eremophila alpestris balcanica & B & & Common & & $\mathrm{N}$ \\
\hline
\end{tabular}

Table 9: The main CORINE land cover types (Level 3) in the IBA Šar Planina Mountain

Tabela 9: Glavni tipi pokrovnosti in rabe tal (po CORINE land cover, 3. nivo) v IBA Sar planina

\begin{tabular}{llc}
\hline $\begin{array}{l}\text { Code/ } \\
\text { Koda }\end{array}$ & $\begin{array}{c}\text { CORINE land cover type/ } \\
\text { tip pokrovnosti in rabe tal }\end{array}$ & $\begin{array}{c}\text { Coverage/ } \\
\text { Pokrovnost (\%) }\end{array}$ \\
\hline 3 II & Broad-leaved forest & 24.2 \\
32 I & Natural grasslands & 56.1 \\
322 & Moors and heathland & 4.3 \\
324 & Transitional woodland-shrub & 7.9 \\
& Other & 7.5 \\
\hline
\end{tabular}

Valley with the cliffs at the locality called Lešnica. Other larger river valleys are Jelovjanska Reka, Mazdrača and (Tearska) Bistrica. Geologically dominant are Paleozoic metamorphic cliffs with carbonates. Pleistocene glacial relief is present in the highest parts. Most of the glacial lakes on Sar Planina Mt are within the boundaries of the site, among which is also Lake Bogovinsko, the largest glacial lake in Macedonia (Figure 5).

\section{Species}

The list for the entire mountain totals ca. 130 species (Melovski et al. 20IO), which indicates that the area has not been studied thoroughly. The site is one of the five most important sites for the Golden Eagle (3-4

Table 10: The main threats to birds and their importance in the IBA Šar Planina Mountain

Tabela 10: Najpomembnejši dejavniki ogrožanja ptic in njihov vpliv v IBA Šar planina

\begin{tabular}{|c|c|c|c|}
\hline $\begin{array}{l}\text { Code/ } \\
\text { Koda }\end{array}$ & $\begin{array}{c}\text { Threat/ } \\
\text { Dejavnik ogrožanja }\end{array}$ & $\begin{array}{c}\text { Threat impact/ } \\
\text { Vpliv }\end{array}$ & $\begin{array}{l}\text { Most affected species/ } \\
\text { Najbolj prizadete vrste }\end{array}$ \\
\hline I4I & Abandonment of pastoral systems & high & G. fulvus, P. graculus \\
\hline 160 & General forestry management & high & forest species \\
\hline 960 & Interspecific faunal relations & high & A. chrysaetos, B. bubo, G. fulvus \\
\hline 230 & Hunting & medium & A. graeca \\
\hline 243 & Trapping, poisoning, poaching & medium & A. chrysaetos, $G$. fulvus \\
\hline 501 & Paths, tracks, cycling tracks & medium & A. chrysaetos, $G$. fulvus \\
\hline 530 & Improved access to site & medium & A. chrysaetos, $G$. fulvus \\
\hline 167 & Forest exploitation without replanting & medium & B. bubo \\
\hline 624 & Mountaineering, rock climbing, speleology & medium & A. chrysaetos, G. fulvus \\
\hline 600 & Sport and leisure structures & low & A. chrysaetos, B. bubo \\
\hline
\end{tabular}




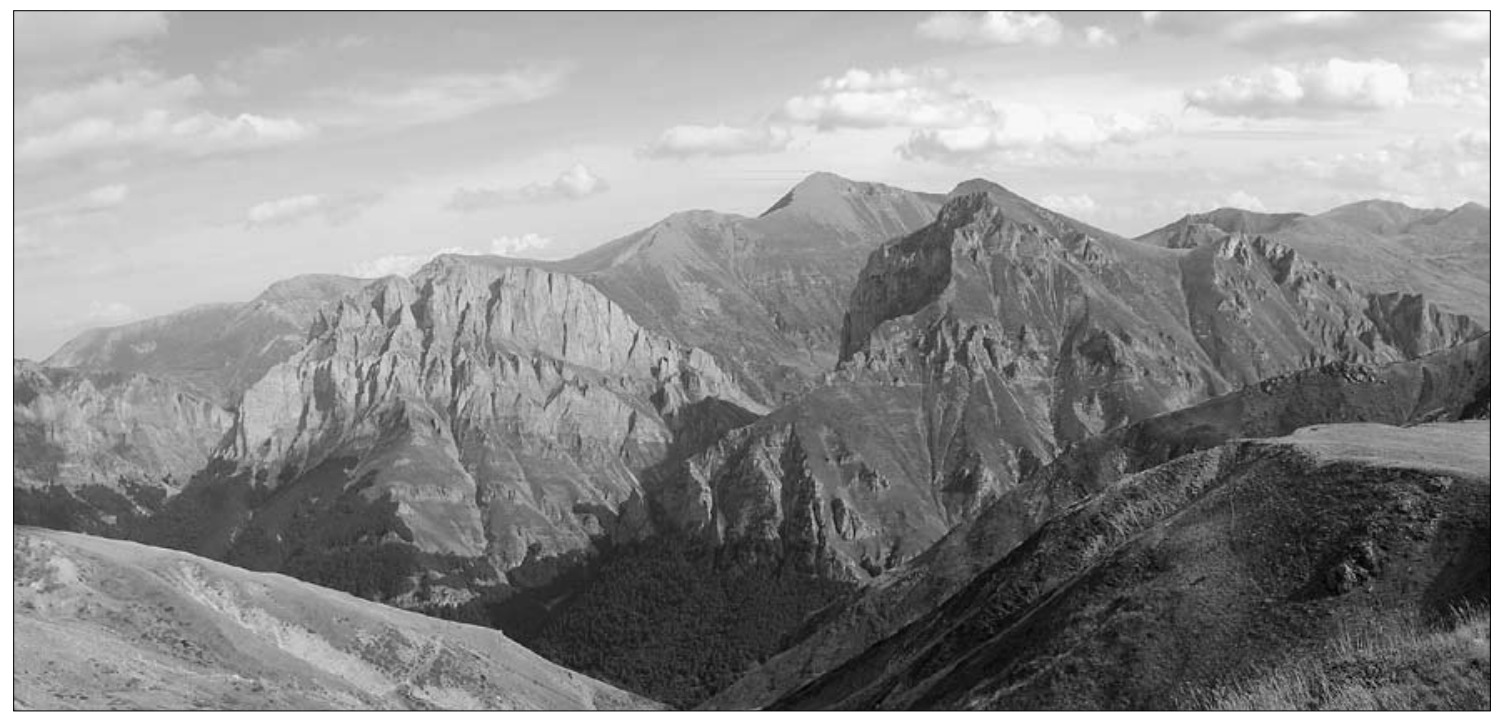

Figure 6: Characteristic landscape of the IBA Šar Planina Mountain (photo: Lj. Melovski)

Slika 6: Značilna krajina IBA Šar planina (foto: Lj. Melovski)

pairs) and Eagle Owl (5-10 pairs) in the country, but the main reason for its designation is the presence of the country's largest populations of four species characteristic of the Eurasian high-montane biome. One pair of Lammergeier Gypaetus barbatus had also bred there until 1981 (GRUBAČ 1990). Historical breeding records of Capercaillie Tetrao urogallus also exist (MATVEJEV 1957), but it has not been confirmed since that period, although good habitats offer possibilities for its survival and, furthermore, the species was registered on the northern slopes of the mountain (Puzović et al. 2009). Until 1990s, non-breeding Griffon Vultures had also been frequent (GRUBAČ 1997), but their number have significantly decreased in the last several years. Other species that are limited to the alpine biome in the Balkan Peninsula and have important national populations on Šar Planina Mt are the Red-billed Chough (50-100 pairs in 1980s, B. Grubač unpubl., but have probably declined since then) and Shore Lark (Table 8).

\section{Habitats and land use}

Large parts of the site are situated above 1,600 m altitude, dominated by pastures on silicate and calcareous bedrocks, as well as heathland with bilberry Vaccinium spp. and Common Juniper Juniperus communis. Both silicate and calcareous cliffs are present, especially in the central part of the mountain (the complex Lešnica in the Pena River Valley). Moorlands are also found around the spring areas of almost all larger rivers (Table
9). Broad-lived forests are dominated by Beech Fagus sylvatica, on some places mixed with Bulgarian Fir Abies borisii-regis. Conifer forests are dominated by the latter, although Spruce Picea abies and Molika Pine Pinus peuce are also present. Around the villages, the natural vegetation is strongly modified. Principal activities are livestock breeding and forestry (Figure 6).

\section{Threats}

Poaching of all game species, possibly including birds of prey, regularly takes place. The area has been in the centre of the armed conflict from 2001, and it is estimated that large numbers of illegally held weapons are present in the region, resulting in widespread poaching, most likely including important bird species and their prey base. Both commercial and illegal logging takes place. Reduction of livestock numbers, especially sheep, has likely influenced the population of the Choughs and vultures. The mountain is a popular mountaineering destination. Construction of new roads and hotels is also planned (Table 10).

\section{Conservation}

The westernmost part of the site falls within the boundaries of Mavrovo National Park. A small protected area (Popova Šapka) lies in the central part of the mountain. Establishment of a new national park, "Šar Planina Mt", is planned, which will entirely cover the rest of the site. The region is also an Emerald Site (MK0000008). 
M. Velevski, B. Hallmann, B. Grubač, T. Lisičanec, E. Stoynov, E. Lisičanec, V. Avukatov, L. Božič \& B. Stumberger: Important Bird Areas in Macedonia: Sites of Global and European Importance

\subsubsection{Radika River Catchment}

\section{General information}

Name in English: Radika River Catchment

Name in Macedonian: Sliv na reka Radika

(Слив на река Радика)

IBA code: $\mathrm{MK} 002$

Criteria: A3, B2

Area: 70,392 ha

Central coordinates: $20^{\circ} 39^{\prime} 53.95^{\prime \prime} \mathrm{E}, 41^{\circ} 40^{\prime} 47.09^{\prime \prime} \mathrm{N}$

Altitude: 610-2,764 $\mathrm{m}$ a.s.l.

Administrative region(s): Gostivar, Rostuše-Mavrovo, Debar, Drugovo, Zajas

\section{Site description}

The site adjoins Šar Planina Mt (MK001) to the SW, while its western boundary follows the national border with Albania in NW Macedonia. The boundary to the south passes under the village of Skudrinje, follows the Mala Reka and Garska Reka Rivers to the locality known as Jama, where it turns north, following the ridges of Dumovica (2,023 m a.s.l.), Pašinica $(1,890$ m a.s.l.), Ahmetovica (1,901 m a.s.l.), Mali Šar (1,993 m a.s.l.), Aramiski Kamen (1,700 m a.s.l.), Dejanovec (1,622 $\mathrm{m}$ a.s.l.) and Vlainica (1,304 $\mathrm{m}$ a.s.l.), from where it turns west and, after passing Bunec, reaches Mala Planina. It occupies small parts of Šar Planina Mt, almost entire Mt Korab and a significant part of Mt Bistra, including Mavrovo Reservoir. The site

Table 11: List of triggering and other important bird species in the IBA Radika River Catchment

Tabela 11: Seznam kvalifikacijskih in drugih pomembnih vrst ptic v IBA Povodje reke Radike

\begin{tabular}{|c|c|c|c|c|c|}
\hline $\begin{array}{l}\text { Species/ } \\
\text { Vrsta }\end{array}$ & $\begin{array}{l}\text { Season/ } \\
\text { Sezona }\end{array}$ & $\begin{array}{l}\text { Year/ } \\
\text { Leto }\end{array}$ & $\begin{array}{c}\text { Population/ } \\
\text { Populacija }\end{array}$ & $\begin{array}{l}\text { Acc./ } \\
\text { Zan. }\end{array}$ & $\begin{array}{l}\text { Criteria/ } \\
\text { Kriteriji }\end{array}$ \\
\hline Prunella collaris & B & 2002 & $10-50$ & C & A3 \\
\hline Tichodroma muraria & B & 2002 & $10-20$ & C & A3 \\
\hline Pyrrhocorax graculus & B & 2005 & $100-200$ & C & A3 \\
\hline Montifringilla nivalis & B & 1998 & $10-30$ & C & A3 \\
\hline Aquila chrysaetos & $\mathbf{R}$ & 2008 & $4-6$ & B & B2 \\
\hline Crex crex & B & 2010 & $30-100$ & C & B2 \\
\hline Bubo bubo & $\mathbf{R}$ & 2008 & $8-15$ & C & B2 \\
\hline Monticola saxatilis & B & 2002-2010 & $30-100$ & C & B2 \\
\hline Falco tinnunculus & $\mathrm{R}$ & & Common & & B2? \\
\hline Gyps fulvus & $\mathrm{N}$ & 2006 & $5-10$ ind. & $\mathrm{C}$ & $\mathrm{N}$ \\
\hline Eremophila alpestris balcanica & B & & Common & & $\mathrm{N}$ \\
\hline Pyrrhocorax pyrrhocorax & B & & Frequent & & $\mathrm{N}$ \\
\hline
\end{tabular}

Table 12: The main CORINE land cover types (Level 3) in the IBA Radika River Catchment

Tabela 12: Glavni tipi pokrovnosti in rabe tal (po CORINE land cover, 3. nivo) v IBA Povodje reke Radike

\begin{tabular}{llc}
\hline $\begin{array}{l}\text { Codel } \\
\text { Koda }\end{array}$ & $\begin{array}{c}\text { CORINE land cover type/ } \\
\text { tip pokrovnosti in rabe tal }\end{array}$ & $\begin{array}{c}\text { Coverage/ } \\
\text { Pokrovnost (\%) }\end{array}$ \\
\hline 3 II & Broad-leaved forest & 42.0 \\
$32 \mathrm{I}$ & Natural grasslands & 34.5 \\
322 & Moors and heathland & $5 . \mathrm{I}$ \\
324 & Transitional woodland-shrub & 8.7 \\
& Other & 9.7 \\
\hline
\end{tabular}

was formerly named "Korab Mt and Radika Gorge" (Heath \& Evans 2000). Only minor corrections to the former site's boundaries have been made, in order to follow the natural features and/or boundaries of Mavrovo National Park.

The site characterizes a complex relief structure, with high mountains, deep river valleys and gorges. The highest mountain in Macedonia - Korab is located here (summit Golem Korab 2,764 m a.s.l.). The geological composition is diverse, with formations from different periods. Also characteristic is the limestone on Mt Bistra. The site's main water bodies are the Radika River and Mavrovo reservoir (Figure 7). 


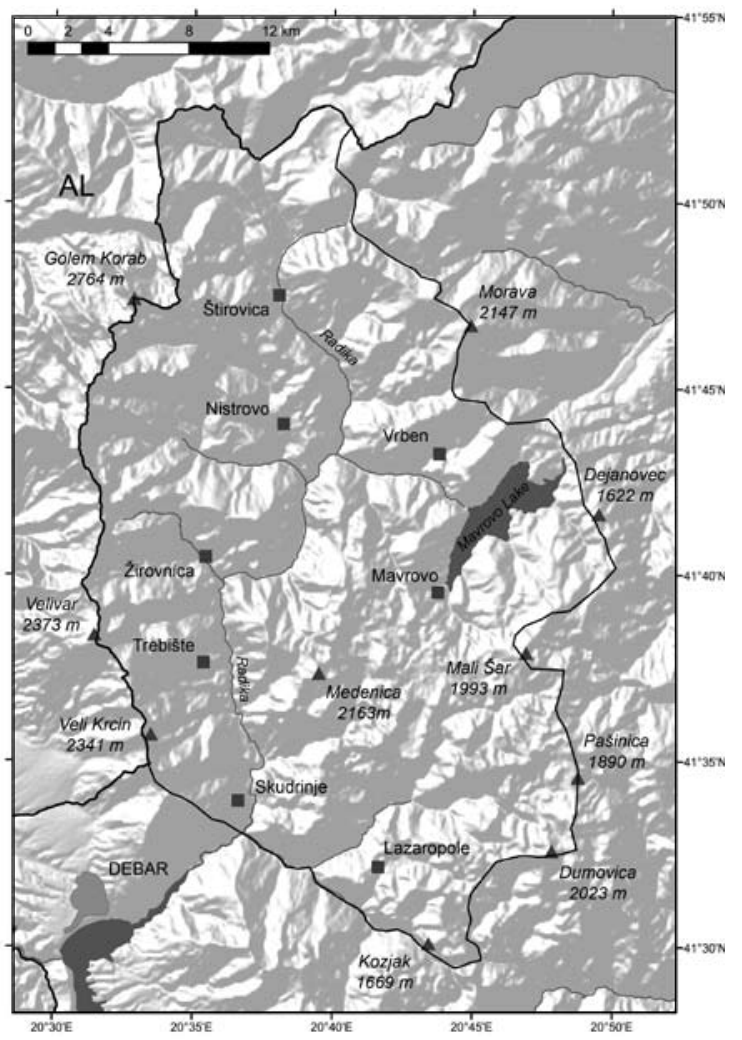

Figure 7: Map of the IBA Radika River Catchment with its main features depicted

Slika 7: Zemljevid IBA Povodje reke Radike z glavnimi značilnostmi območja

\section{Species}

Biogeographically and ecologically, the site is almost identical to Šar Planina Mt, thus boasting almost identical bird community composition and ornithological importance. The list of registered bird species amounts to over 140 species (VELEVSKI et al. 2003A, Micevski 20IO). Triggering species are the Golden Eagle (4-6 pairs) and Eagle Owl (8-15 pairs), but populations of the four species characteristic of the Eurasian high-montane biome, occurring mostly in the highest parts of Mt Korab above 2,200 m a.s.l. are also relatively large. The site holds internationally important populations of Rock Partridge and Rock Thrush, while Common Kestrel, Red-billed Chough and Shore Lark are probably also present with important populations. Non-breeding Griffon Vultures used to have important roosting site here, numbering up to 60 individuals in the 1990s (GRUBAČ 1997), but are now seen only sporadically (Table 11). The Black Vulture Aegypius monachus and Lammergeier Gypaetus barbatus have also been known to occur here (GRUBAČ 1998 \& 2002).

\section{Habitats and land use}

Broad-leaved forests are dominated by oaks (several species and communities) and Beech Fagus sylvatica. Very often, mixed Beech and Bulgarian Fir Abies borisii-regis forests are found, as well as mixed oak and fir forests in some places. Fir forests form pure stands. A smaller pure stand of Spruce Picea abies is also present. High-montane grasslands used as summer pastures for livestock and heathlands are the second dominant habitat type here (Table 12), but general landscape is formed by steep limestone cliffs (Figure 8).

\section{Threats}

Although protected as a national park, poaching is common in the border regions, and probably had direct and indirect impacts on raptors (direct persecution,

Table 13: The main threats to birds and their importance in the IBA Radika River Catchment

Tabela 13: Najpomembnejši dejavniki ogrožanja ptic in njihov vpliv v IBA Povodje reke Radike

\begin{tabular}{|c|c|c|c|}
\hline $\begin{array}{l}\text { Code/ } \\
\text { Koda }\end{array}$ & $\begin{array}{c}\text { Threat/ } \\
\text { Dejavnik ogrožanja }\end{array}$ & $\begin{array}{l}\text { Threat impact/ } \\
\text { Vpliv }\end{array}$ & $\begin{array}{l}\text { Most affected species/ } \\
\text { Najbolj prizadete vrste }\end{array}$ \\
\hline 960 & Interspecific faunal relations & high & A. chrysaetos, B. bubo, G. fulvus \\
\hline I4I & Abandonment of pastoral systems & medium & P. graculus, G. fulvus \\
\hline 160 & General forestry management & medium & forest species \\
\hline 243 & Trapping, poisoning, poaching & medium & G. fulvus, A. chrysaetos \\
\hline $4 \mathrm{IO}$ & Industrial or commercial areas & medium & A. chrysaetos, $P$ graculus, $P$. collaris, $M$. nivalis \\
\hline 501 & Paths, tracks, cycling tracks & low & A. chrysaetos \\
\hline 624 & Mountaineering, rock climbing, speleology & low & A. chrysaetos, G. fulvus \\
\hline 530 & Improved access to site & low & A. chrysaetos, G. fulvus \\
\hline
\end{tabular}


M. Velevski, B. Hallmann, B. Grubač, T. Lisičanec, E. Stoynov, E. Lisičanec, V. Avukatov, L. Božıč \& B. Stumberger: Important Bird Areas in Macedonia: Sites of Global and European Importance

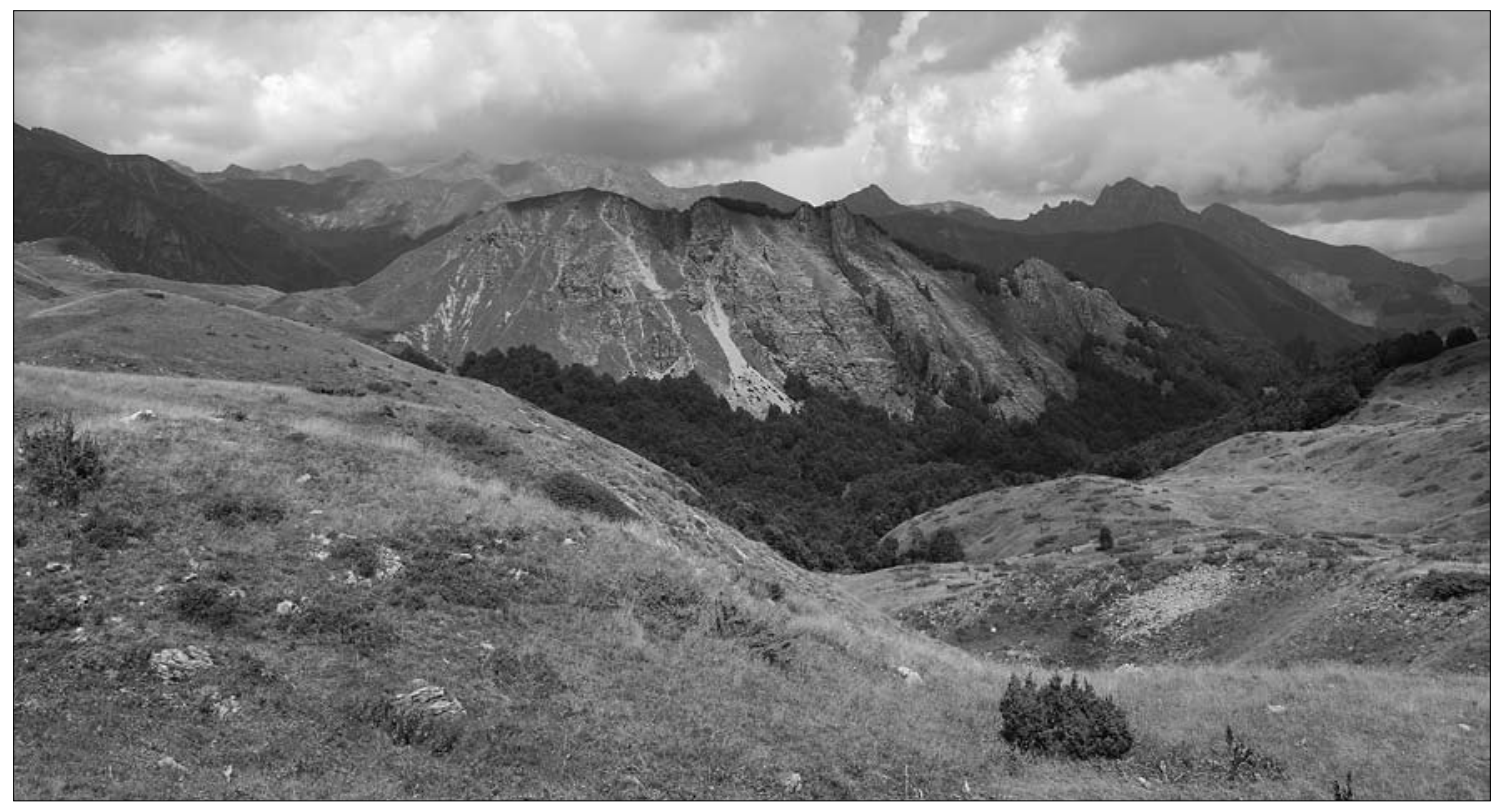

Figure 8: Characteristic landscape of the IBA Radika River Catchment (photo: Lj. Melovski)

Slika 8: Značilna krajina IBA Povodje reke Radike (foto: Lj. Melovski)

prey base reduction, disturbance). Some 9,000 inhabitants live in the region, partially depending on its natural resources, especially pastures and forests. Decrease in the number of livestock, especially sheep, has been significant, probably having a negative impact on vulture populations and Choughs. The National Park management implements forest management practices that should be improved to maintain higher biodiversity. Construction of two hydro-power plants with reservoirs and connected water-supply channels meant to provide water from streams as much as $18 \mathrm{~km}$ far is planned for near future. One of them, "Boškov Most", is located on the site's southern boundary, while the other, "Lukovo Pole", is in the core area, which no doubt means that significant deterioration can be expected. In addition, at least six small hydro-power plants are planned, some of them in highly sensitive regions (Table 13).

\section{Conservation}

The entire site lies within the boundaries of Mavrovo National Park, which has been also identified as an Emerald Site (MK0000007). The first management plan of the Park is presently under development by the Park's management and Oxfam Italia (2009-2010). Two very small protected areas (Dlabok Dol and Garska Reka) are also located within this site.

\subsubsection{Lake Ohrid}

\section{General information}

Name in English: Lake Ohrid

Name in Macedonian: Ohridsko Ezero (Охридско Езеро)

IBA code: $\mathrm{MK} 005$

Criteria: A4iii, B1i, B2

Area: 24,736 ha

Central coordinates: $20^{\circ} 43^{\prime} 52.65^{\prime \prime} \mathrm{E}, 41^{\circ} 03^{\prime} 36.88^{\prime \prime} \mathrm{N}$

Altitude: 695-900 m a.s.l.

Administrative region(s): Struga, Debarca, Ohrid

\section{Site description}

Situated in the SW of the country, this site includes part of Lake Ohrid, following its shore line and the national border with Albania, which runs across the lake surface. The site is adjacent to the Albanian IBA site "Lake Ohrid" (AL002, Heath \& Evans 2000).

The shore line of the lake is polygenetic, with limnogene shore (from lake sediments) situated in the north. At Ljubaništa and St. Naum there is the potamogene coast, while the western slopes of $\mathrm{Mt}$ Galičica are of tectogene and abrasive origin, with characteristic cliffs. The coastline is dominated by Triassic limestones. The lake is tectonic, some 3 million years old, with max. depth of $286 \mathrm{~m}$ (Figure 9). 


\section{Species}

The site's bird fauna has been studied relatively well (MiceVsKi 2003), although precise quantitative data and estimates for the breeding species are missing. In total, 89 waterbird species have been recorded, including the arable land and swamps surrounding the lake (presently largely dried and of little importance). Winter census data are available for the periods 1987-1991, 1997-2000, 2002, 2010 and 2011 (MiceVski 1996, MiceVski 1998, Fremuth et al. 2000, Wetlands International in litt., MES unpubl.). The total number of wintering waterbirds on the lake surface (Macedonian part only) was between 79,000 individuals in 1989 (WetLands International in litt.) and 24,000 individuals in 1997 (FREMUTH et al. 2000), but only about 10,000 and 17,000 were counted in 2010 and 2011, respectively (MES unpubl.). The most numerous species is the Coot (as many as 60,000 ind. in 1989, but only 7,500 in 2010), followed by the Pochard (500-7,000 ind., but only 150 and 300 in 2010 and 2011, respectively), Red-crested Pochard (350-7,000 ind.), Tufted Duck (240-6,500 ind., but only 20 in 2010) and Black-necked Grebe (130-3,600 ind.). There was a substantial decrease in numbers of the latter in the period after 1991, and the threshold of 2,200 individuals has not been met again after then. Triggering species for the breeding period are the Pygmy Cormorant with some 50-100 pairs breeding in 2000 (MiCEVSKI 2003), which has met also the B1i criteria only in 1989 and 2002 (MicevsKI I996, Wetlands International in litt.), and the Goosander, which most probably bred there in 2006 (Š́коврі́коví et al. 2006). The Great Crested Grebe is

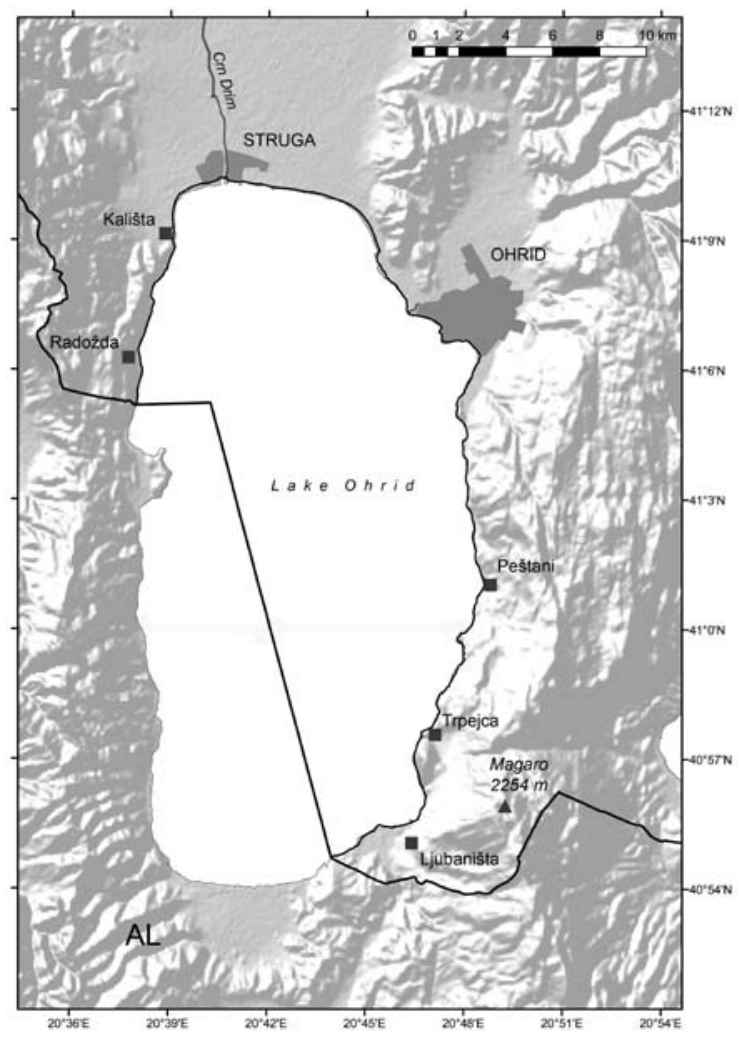

Figure 9: Map of the IBA Lake Ohrid with its main features depicted

Slika 9: Zemljevid IBA Ohridsko jezero z glavnimi značilnostmi območja

Table 14: List of triggering and other important bird species in the IBA Lake Ohrid

Tabela 14: Seznam kvalifikacijskih in drugih pomembnih vrst ptic v IBA Ohridsko jezero

\begin{tabular}{|c|c|c|c|c|c|}
\hline $\begin{array}{l}\text { Species/ } \\
\text { Vrsta }\end{array}$ & $\begin{array}{l}\text { Season/ } \\
\text { Sezona }\end{array}$ & $\begin{array}{l}\text { Year/ } \\
\text { Leto }\end{array}$ & $\begin{array}{c}\text { Population/ } \\
\text { Populacija }\end{array}$ & $\begin{array}{l}\text { Acc./ } \\
\text { Zan. }\end{array}$ & $\begin{array}{l}\text { Criteria/ } \\
\text { Kriteriji }\end{array}$ \\
\hline all waterbirds & W & $1987-2002$ & $20,000-79,000$ ind. & $\mathbf{A}$ & A4iii \\
\hline Podiceps nigricollis & $\mathbf{W}$ & I988-I991 & $2,600-3,600$ ind. & $\mathbf{A}$ & B1i \\
\hline Netta rufina & W & I987-20II & $350-7,000$ ind. & A & B1i \\
\hline Fulica atra & W & $1987-2011$ & $13,000-60,000$ ind. & A & B1i \\
\hline Mergus merganser & B & 2006 & $\mathbf{I}-3$ & A & B1i \\
\hline Phalacrocorax pygmeus & B & 2000 & $50-100$ & $\mathrm{C}$ & B2 \\
\hline Podiceps cristatus & W & I99I-2000 & $800-\mathrm{I}, 400$ ind. & A & $\mathrm{N}$ \\
\hline Podiceps cristatus & B & -2003 & 20-IOO & $\mathrm{C}$ & $\mathrm{N}$ \\
\hline Phalacrocorax pygmeus & W & $1989-2002$ & I,IOO-3,250 ind. & A & $\mathrm{N}$ \\
\hline Aythya ferina & W & $1987-2000$ & $500-7,000$ ind. & A & $\mathrm{N}$ \\
\hline Aythya fuligula & W & I989-I999 & $240-6,500$ ind. & A & $\mathrm{N}$ \\
\hline
\end{tabular}




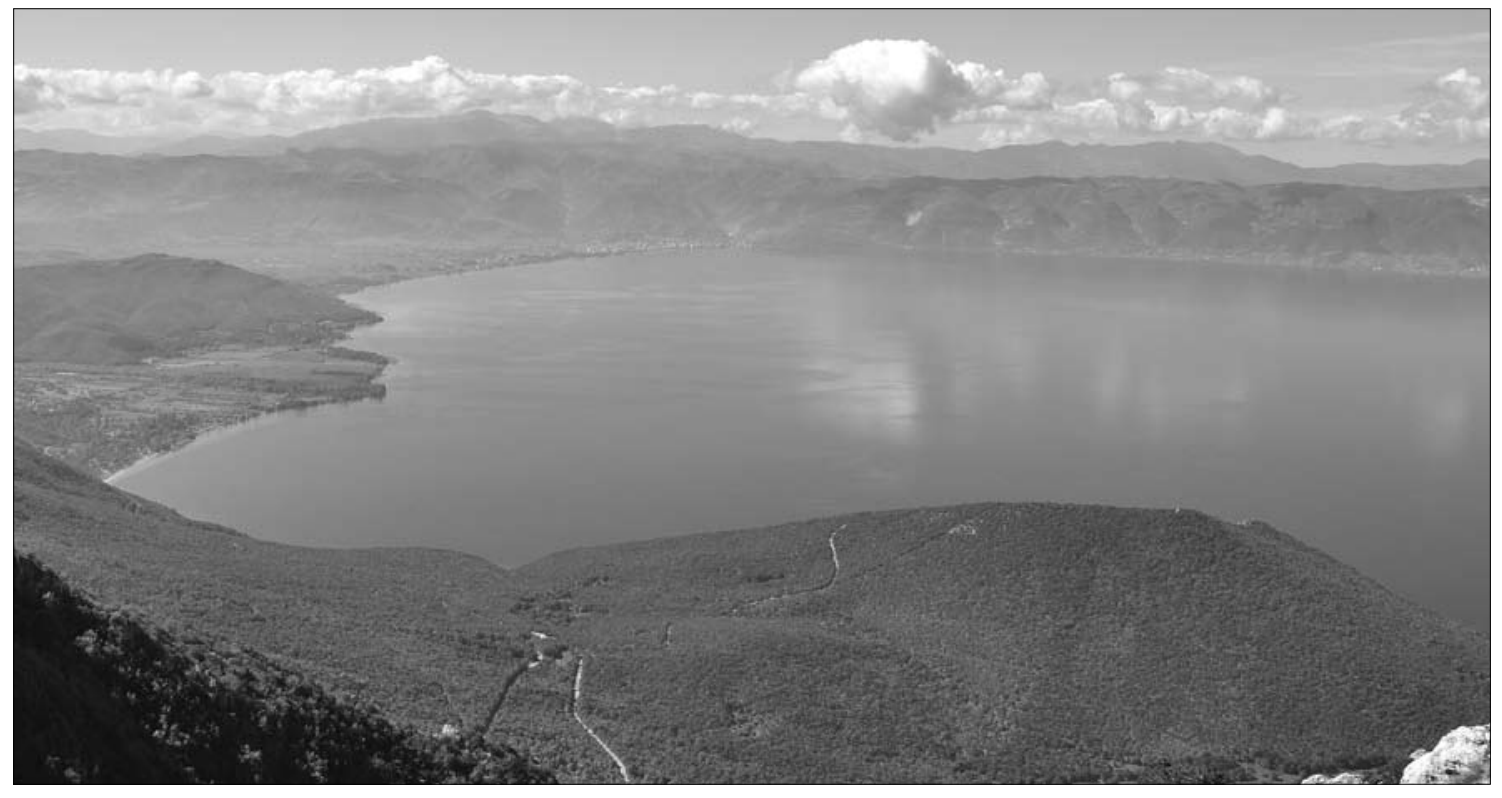

Figure 10: Characteristic landscape of the IBA Lake Ohrid (photo: S. Hristovski)

Slika 10: Značilna pokrajina IBA Ohridsko jezero (foto: S. Hristovski)

Table 15: The main CORINE land cover types (Level 3) in the IBA Lake Ohrid

Tabela 15: Glavni tipi pokrovnosti in rabe tal (po CORINE land cover, 3. nivo) v IBA Ohridsko jezero

\begin{tabular}{llc}
\hline $\begin{array}{l}\text { Code/ } \\
\text { Koda }\end{array}$ & $\begin{array}{l}\text { CORINE land cover type/ } \\
\text { tip pokrovnosti in rabe tal }\end{array}$ & $\begin{array}{c}\text { Coverage/ } \\
\text { Pokrovnost (\%) }\end{array}$ \\
\hline \multirow{2}{5}{ I2 } & Water bodies & 99.6 \\
& Other & 0.4 \\
\hline
\end{tabular}

considered one of the most frequent breeding birds on the Lake (Micevski 2003) (Table 14).

The northern shallow part of the lake is of the highest importance for wintering waterbirds (MICEVSKI 1996), with the Coot and Red-crested Pochard being the most abundant, which is explained by the presence of extensive reedbeds, underwater Chara vegetation and influx of nutrients by the Satoka River.

\section{Habitats and land use}

The lake constitutes the greater part of the site (Table 15). Cliffs along the western and especially eastern shoreline are also part of the site. The most extensive reedbeds are found on the northern shore of the Lake, although small reed patches can be found along the entire shoreline. The lake is oligotrophic. Smaller xerophylous oak forests are found within the site boundaries (Figure 10).

\section{Threats}

Lake Ohrid is an attractive tourist destination, and practically the entire shoreline is strewn with tourist

Table 16: The main threats to birds and their importance in the IBA Lake Ohrid

Tabela 16: Najpomembnejši dejavniki ogrožanja ptic in njihov vpliv v IBA Ohridsko jezero

\begin{tabular}{llcc}
\hline $\begin{array}{l}\text { Code/ } \\
\text { Koda }\end{array}$ & \multicolumn{1}{c}{$\begin{array}{c}\text { Threat/ } \\
\text { Dejavnik ogrožanja }\end{array}$} & Threat impact/Vpliv & $\begin{array}{c}\text { Most affected species/ } \\
\text { Najbolj prizadete vrste }\end{array}$ \\
\hline 600 & Sport and leisure structures & high & $\begin{array}{l}\text { M. merganser } \\
803\end{array}$ \\
Infilling of ditches, dykes, ponds, marshes or pits & high & P. pygmeus \\
\hline
\end{tabular}


resorts. For the needs of tourism, beeches are expanded and reedbeds removed or dried out. Eutrophication probably takes place (Table 16). No zoning concept has been implemented.

\section{Conservation}

The Lake is protected as a Nature Monument, and is also proposed as an Emerald Site (MK0000024). Together with the town of Ohrid and its wider surrounding, it is listed on UNESCO's list of World Natural and Cultural Heritage Sites. The site also includes a small portion of Galičica National Park.

\subsubsection{Lake Prespa}

\section{General information}

Name in English: Lake Prespa

Name in Macedonian: Prespansko Ezero

(Преспанско Езеро)

IBA code: $\mathrm{MK} 006$

Criteria: A1, A4i, B1i, B2

Area: 19,842 ha

Central coordinates: $21^{\circ} 00^{\prime} 43.56^{\prime \prime} \mathrm{E}, 40^{\circ} 55^{\prime} 58.94^{\prime \prime} \mathrm{N}$

Altitude: $850-970 \mathrm{~m}$ a.s.l.

Administrative region(s): Resen

\section{Site description}

The site includes the Macedonian part of Lake Prespa (Macro Prespa) in SW Macedonia, cliffs on its shoreline and swamps near the villages of Stenje and Nakolec, as well as wet meadows, reedbeds and fishponds between the villages of Sir Han and Asamati. It is adjacent to the sites "Lake Megali Prespa" (AL003) in Albania and "Lake Mikri Prespa and Lake Megali Prespa" (GR047) in Greece (Heath and Evans 2000).

Lake Prespa's coast is polygenetic; the east coast (slopes of Mt Pelister) is of potamogene character as a result of several river inflows from the mountain (Brajčinska Reka, Kranska Reka etc.). The northern coast is basically of limnogene character, and along the northern shoreline it is of phytogene origin (owing to its wetland vegetation). On the western coast, the shoreline is of abrasive character, with notable cliffs, as a result of the geological composition represented by Triassic limestone. The most important river is the Golema Reka in the north. The max. depth of the lake reaches $54 \mathrm{~m}$ (Figure 11).

\section{Species}

Bird fauna of Lake Prespa is among the best studied in the country (Micevski 1998). In total, 103 waterbird species have been recorded. Winter censuses data are

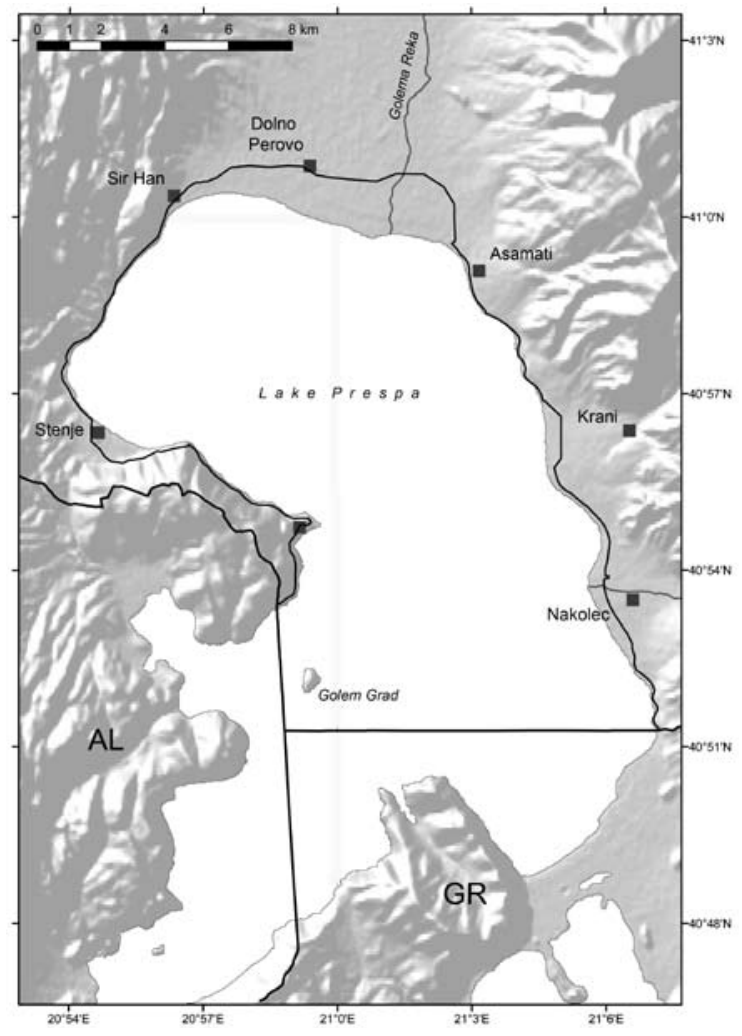

Figure 11: Map of the IBA Lake Prespa with its main features depicted

Slika 11: Zemljevid IBA Prespansko jezero z glavnimi značilnostmi območja

available for the periods/years 1987-1990, 19972002, 2004-2006 and 2009-2011 (MiCEVSKI \& SChNeIDer 1997, Fremuth et al. 2000, VAsić 2009A, Wetlands International in litt., MES unpubl.). The most numerous has been the Coot $(1,000-20,700$ ind.), followed by Tufted Duck (between as few as 12 ind. in 2002 and 9,000-12500 ind. in 19881989), Black-necked Grebe (up to 5,800 in 2004, with decline in numbers thereupon, the exception being 2009 with 3900 ind.), Pochard (12,500 ind. in 1988, 9,000 ind. in 1989, but only 15 ind. in 2004), and Teal Anas crecca (up to 2,500 ind.). The total number of wintering waterbirds exceeded 20,000 individuals only in 2009, when 31,500 waterbirds were counted (VAsić 2009A). The island Golem Grad holds the largest Cormorant colony in the country (2,500-3,000 pairs, VAsIć 20IO) and the only colony (ca. 50 pairs) of the Yellow-legged Gull in Macedonia (VAsić 2009A). 30-50 pairs of Goosander breed along the lake shores (VAsić 2OIO), with some of them also wintering on the lake. Up to 
M. Velevski, B. Hallmann, B. Grubač, T. Lisičanec, E. Stoynov, E. Lisičanec, V. Avukatov, L. Božič \& B. Stumberger: Important Bird Areas in Macedonia: Sites of Global and European Importance

Table 17: List of triggering and other important bird species in the IBA Lake Prespa

Tabela 17: Seznam kvalifikacijskih in drugih pomembnih vrst ptic v IBA Prespansko jezero

\begin{tabular}{|c|c|c|c|c|c|}
\hline $\begin{array}{l}\text { Species/ } \\
\text { Vrsta }\end{array}$ & $\begin{array}{l}\text { Season/ } \\
\text { Sezona }\end{array}$ & $\begin{array}{l}\text { Year/ } \\
\text { Leto }\end{array}$ & $\begin{array}{c}\text { Population/ } \\
\text { Populacija }\end{array}$ & $\begin{array}{l}\text { Acc.l } \\
\text { Zan. }\end{array}$ & $\begin{array}{l}\text { Criteria/ } \\
\text { Kriteriji }\end{array}$ \\
\hline Pelecanus crispus & $\mathbf{N}$ & 2008-2010 & $300-1,000$ ind. & $\mathrm{C}$ & A1, A4i, B1i \\
\hline Pelecanus onocrotalus & $\mathbf{N}$ & 2008-2010 & $150-500$ ind. & $\mathrm{C}$ & A4i, B1i \\
\hline Mergus merganser & B & 2008-2010 & $30-50$ & B & B1i \\
\hline Mergus merganser & W & I987-201I & $2-22$ ind. & $\mathbf{A}$ & B1i \\
\hline Ixobrychus minutus & B & 2009 & $50-200$ & C & B2 \\
\hline Podiceps cristatus & W & 2OIO-2OII & $2,000-3,400$ ind. & A & $\mathrm{N}$ \\
\hline Podiceps cristatus & $\mathrm{B}$ & I987-2010 & $100-600$ & $\mathrm{C}$ & $\mathrm{N}$ \\
\hline Podiceps nigricollis & W & $1989-2004$ & $\mathrm{I}, 400-5,800$ ind. & A & $\mathrm{N}$ \\
\hline Phalacrocorax pygmeus & $\mathrm{B}$ & 1993 & $\mathrm{IO}-2 \mathrm{O}$ & $\mathrm{C}$ & $\mathrm{N}$ \\
\hline Phalacrocorax carbo sinensis & $\mathrm{B}$ & 2008-2010 & $2,500-3,000$ & $\mathrm{~B}$ & $\mathrm{~N}$ \\
\hline Casmerodius albus & $\mathrm{N}$ & 2010 & $60-150$ ind. & $\mathrm{B}$ & $\mathrm{N}$ \\
\hline Anas strepera & $\mathrm{B}$ & $-\mathrm{I} 998$ & O-IO & $\mathrm{C}$ & $\mathrm{N}$ \\
\hline Aythya nyroca & $\mathrm{B}$ & $1998-2008$ & $3-\mathrm{IO}$ & $\mathrm{B}$ & $\mathrm{N}$ \\
\hline Aythya ferina & W & 1989-1999 & $\mathrm{I}, 850-3,200$ ind. & A & $\mathrm{N}$ \\
\hline Aythya fuligula & W & 1988-1997 & I0o-9,000 ind. & A & $\mathrm{N}$ \\
\hline Fulica atra & W & 1997-1998 & $9,000-9,750$ ind. & A & $\mathrm{N}$ \\
\hline
\end{tabular}

300 individuals of Dalmatian Pelican and up to 100 individuals of White Pelican can be seen concurrently on the lake surface. Both pelican species breed at Lake Mikri Prespa in Greece with estimated 1,169 pairs of Dalmatian and 332 pairs of White Pelican in 2010 (Society for Protection of Prespa 20i i). They visit Lake Macro Prespa for feeding (when they can be readily seen accompanying fishermen's boats) and roosting, especially along the shoreline between the villages of Konjsko and Stenje. On the basis of these numbers, we have estimated the number of non-breeding birds present in the Macedonian part of Lake Prespa at 300-1,000 individuals of the Dalmatian Pelican and 150-500 individuals of the White Pelican. The population of the Ferruginous

Table 18: The main CORINE land cover types (Level 3) in the IBA Lake Prespa

Tabela 18: Glavni tipi pokrovnosti in rabe tal (po CORINE land cover, 3. nivo) v IBA Prespansko jezero

\begin{tabular}{llc}
\hline $\begin{array}{l}\text { Code/ } \\
\text { Koda }\end{array}$ & $\begin{array}{c}\text { CORINE land cover type/ } \\
\text { tip pokrovnosti in rabe tal }\end{array}$ & $\begin{array}{c}\text { Coverage/ } \\
\text { Pokrovnost (\%) }\end{array}$ \\
\hline \multirow{5}{5}{ I2 } & Water bodies & 9 I.O \\
\multirow{2}{*}{4 II } & Inland marshes & 4.9 \\
& Other & $4 . \mathrm{I}$ \\
\hline
\end{tabular}

Duck has been estimated at only 3-4 pairs breeding in the presently dry fishpond at Asamati village in 1995 (MiceVsKi I998), and at 3-10 pairs by Vasić (2010). The probable breeding population of the Gadwall has also been estimated to 10 pairs at the most (VAsIć 20IO), supposedly on the grounds of observations by Micevski (1998) in the breeding period. Some 20-50 breeding pairs of the Great Egret have been estimated to breed at Lake Prespa (VAsić 20I0), although the breeding colony may possibly resides in its entirety in Greece. Still, the species uses the Macedonian part of the lake for foraging as well. MiceVsKi (I998) reports on minimum 30 breeding pairs of the Great Crested Grebe along the northern shore, while Vasić (2OIO) gives an estimate at 500750 pairs for Galičica National Park (both Ohrid and Prespa shorelines included), which gives a rather imprecise, but still high estimate of the breeding population at $100-600$ pairs (Table 17).

\section{Habitats and land use}

The lake surface constitutes the greater part of the site, but extensive reedbeds are found along the northern shore (between the villages of Sir Han and Asamati), and along the eastern shoreline (near Stenje and at Nakolec) (Table 18). Remains of riparian forests can also be seen. There are two drained fishponds with recent plans for reactivation. Large sand beach in process of succession is found around the village 


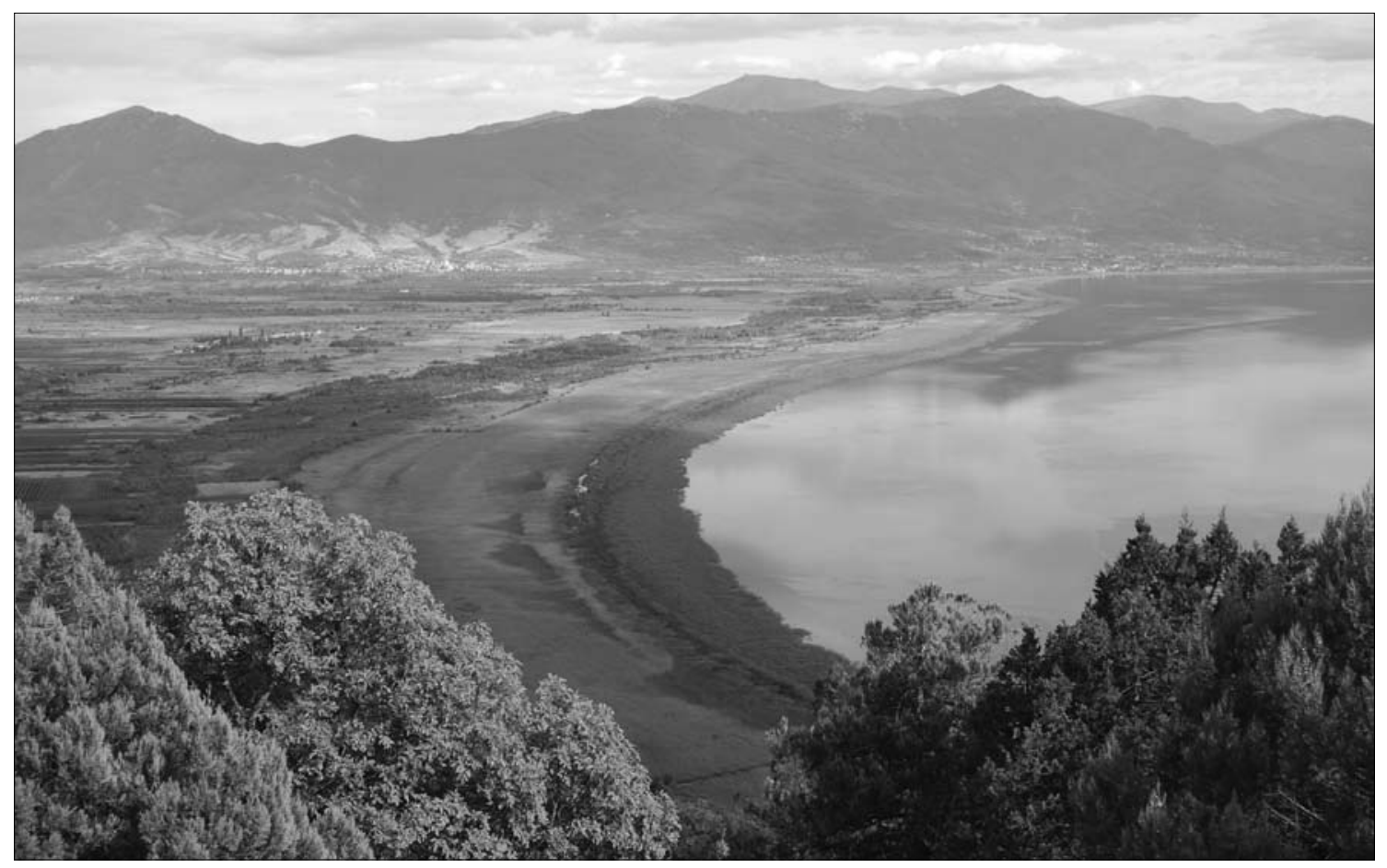

Figure 12: Characteristic landscape of the IBA Lake Prespa (photo: Lj. Melovski)

Slika 12: Značilna krajina IBA Prespansko jezero (foto: Lj. Melovski)

of Stenje on the northern shore. Wet meadows and Carex fields spread around the village of Perovo. Cliffs are present on the island Golem Grad and between Stenje and Konjsko villages, overgrown by old Greek Juniper Juniperus excelsa forests (Figure 12).

\section{Threats}

Sand extraction and conversion of meadows into intensively managed orchards are widely practiced by the local population. Poaching is also common.
Tourism activities have decreased in the last two decades, although plans for the construction of new hotels exist. Water quality decreased, and the lake is presently treated as eutrophic (Levkov et al. 2007) (Table 19).

\section{Conservation}

The entire lake is protected as a Nature Monument; since 1996, its northern shallow parts and shores have been protected as Strict Nature Reserve Ezerani

Table 19: The main threats to birds and their importance in the IBA Lake Prespa

Tabela 19: Najpomembnejši dejavniki ogrožanja ptic in njihov vpliv v IBA Prespansko jezero

\begin{tabular}{llll}
\hline $\begin{array}{c}\text { Code/ } \\
\text { Koda }\end{array}$ & \multicolumn{1}{c}{$\begin{array}{c}\text { Threat/ } \\
\text { Dejavnik ogrožanja }\end{array}$} & $\begin{array}{c}\text { Threat impact/ } \\
\text { Vpliv }\end{array}$ & $\begin{array}{c}\text { Most affected species/ } \\
\text { Najbolj prizadete vrste }\end{array}$ \\
\hline IOO & Cultivation & high & $\begin{array}{c}\text { I. minutus } \\
\text { wintering waterbirds }\end{array}$ \\
$70 \mathrm{I}$ & Water pollution & high & wintering waterbirds \\
952 & Eutrophication & high & Anatidae \\
243 & Trapping, poisoning, poaching & medium & P. crispus, P. onocrotalus \\
600 & Sport and leisure structures & medium & A. nyroca, I. minutus \\
\hline
\end{tabular}


M. Velevski, B. Hallmann, B. Grubač, T. Lisičanec, E. Stoynov, E. Lisičanec, V. Avukatov, L. Božič \& B. Stumberger: Important Bird Areas in Macedonia: Sites of Global and European Importance

$(2,080 \mathrm{ha})$. This reserve is presently in the process of re-proclamation (in the category Nature Park), and new boundaries covering 1,917 ha are propose. Temporal and spatial zoning of the lake surface in order to preserve waterbirds is missing. The coast from Sir Han to the border with Albania and the island Golem Grad are integrated into Galičica National Park. All three protected areas are proposed as Emerald Sites (MK0000001, MK0000002 and MK0000025, respectively). It is also a Ramsar Site of international importance, among other criteria due to its importance for waterbirds. Management plans are under development for Galičica and Ezerani.

\subsubsection{Demir Kapija Gorge}

\section{General information}

Name in English: Demir Kapija Gorge

Name in Macedonian: Demirkapiska Klisura (Демиркаписка Клисура)

IBA code: $\mathrm{MK} 008$

Criteria: A1, A3, B2

Area: 9,665 ha

Central coordinates: $22^{\circ} 18^{\prime} 20.44^{\prime \prime} \mathrm{E}, 41^{\circ} 23^{\prime} 46.84^{\prime \prime N}$

Altitude: $110-928 \mathrm{~m}$ a.s.l.

Administrative region(s):

Demir Kapija, Gevgelija, Konče, Valandovo

\section{Site description}

Situated E-SE of the town of Demir Kapija in southern Macedonia, the site includes about a half (upper part) of the longest gorge of the Vardar River (in total ca. $20 \mathrm{~km}$ long). The border runs along the last houses of Demir Kapija, turns south towards Čiflik and Dren villages, then follows the Drenska Reka (a tributary of the Vardar) to the east to the Stefan ridge, where it turns north. Then it continues towards the hills of Študer (609 $\mathrm{m}$ a.s.1.) and Veternikot, crosses the Vardar and, by following the ridges of Ilovski Cukar (524 m a.s.1.), Golem (928 $\mathrm{m}$ a.s.l.) and Mal Karadag (707 m a.s.l.), reaches Vaganar (880 $\mathrm{m}$ a.s.l.). From there it turns west and follows the intermittent rivulets Linan Dere and Dobroište, runs through Iberlija village and follows the Lesovo rivulet to Kurtlu Čuka. Then it continues south, and via Sreden Rid (556 m a.s.l.) descends to the Vardar River, crossing it at Demir Kapija. In this way, the border is strongly modified as for the one in Heath \& Evans (2000).

Main morphological characteristic is the gorge, which is in certain parts a typical canyon with walls of over $200 \mathrm{~m}$ high. Jurassic limestones are dominant in the beginning of the gorge, while in the SE the geological composition is of Jurassic magmatic rocks. Main tributaries of the Vardar are the Iberliska (Čelevečka) Reka (forming a typical canyon) and the Golema Javorica (Figure 13).

Table 20: List of triggering and other important bird species in the IBA Demir Kapija Gorge

Tabela 20: Seznam kvalifikacijskih in drugih pomembnih vrst v IBA Soteska Demir Kapija

\begin{tabular}{|c|c|c|c|c|c|}
\hline $\begin{array}{l}\text { Species/ } \\
\text { Vrsta }\end{array}$ & $\begin{array}{l}\text { Season/ } \\
\text { Sezona }\end{array}$ & $\begin{array}{l}\text { Year/ } \\
\text { Leto }\end{array}$ & $\begin{array}{c}\text { Population/ } \\
\text { Populacija }\end{array}$ & $\begin{array}{l}\text { Acc.l } \\
\text { Zan. }\end{array}$ & $\begin{array}{l}\text { Criteria/ } \\
\text { Kriteriji }\end{array}$ \\
\hline Neophron percnopterus & B & $2006-2010$ & $2-3$ & $\mathbf{A}$ & A1 \\
\hline Alectoris graeca & $\mathbf{R}$ & & Common & & A3 \\
\hline Oenanthe hispanica & B & & Common & & A3 \\
\hline Sylvia cantillans & B & & Abundant & & A3 \\
\hline Sitta neumayer & $\mathbf{R}$ & & Common & & A3 \\
\hline Emberiza melanocephala & B & & Frequent & & A3 \\
\hline Circaetus gallicus & B & 2007 & $5-8$ & B & B2 \\
\hline Accipiter brevipes & B & 2005 & $4^{-6}$ & B & B2 \\
\hline Ciconia nigra & B & 2010 & I & A & $\mathrm{N}$ \\
\hline Gyps fulvus & $\mathrm{R}$ & $2009-2010$ & $6-7$ & A & $\mathrm{N}$ \\
\hline Buteo rufinus & $\mathrm{R}$ & 2010 & $\mathrm{I}-2$ & $\mathrm{~B}$ & $\mathrm{~N}$ \\
\hline Milvus migrans & B & 2010 & I & $\mathrm{A}$ & $\mathrm{N}$ \\
\hline Aquila pennata & B & 2010 & I & A & $\mathrm{N}$ \\
\hline Aquila chrysaetos & $\mathrm{R}$ & 2010 & $\mathrm{I}-2$ & A & $\mathrm{N}$ \\
\hline Falco biarmicus & B & 2007 & O-I & B & \\
\hline Falco peregrinus & $\mathrm{R}$ & 2009 & 2 & B & $\mathrm{N}$ \\
\hline Bubo bubo & $\mathrm{R}$ & 2005 & $3-5$ & B & $\mathrm{N}$ \\
\hline
\end{tabular}




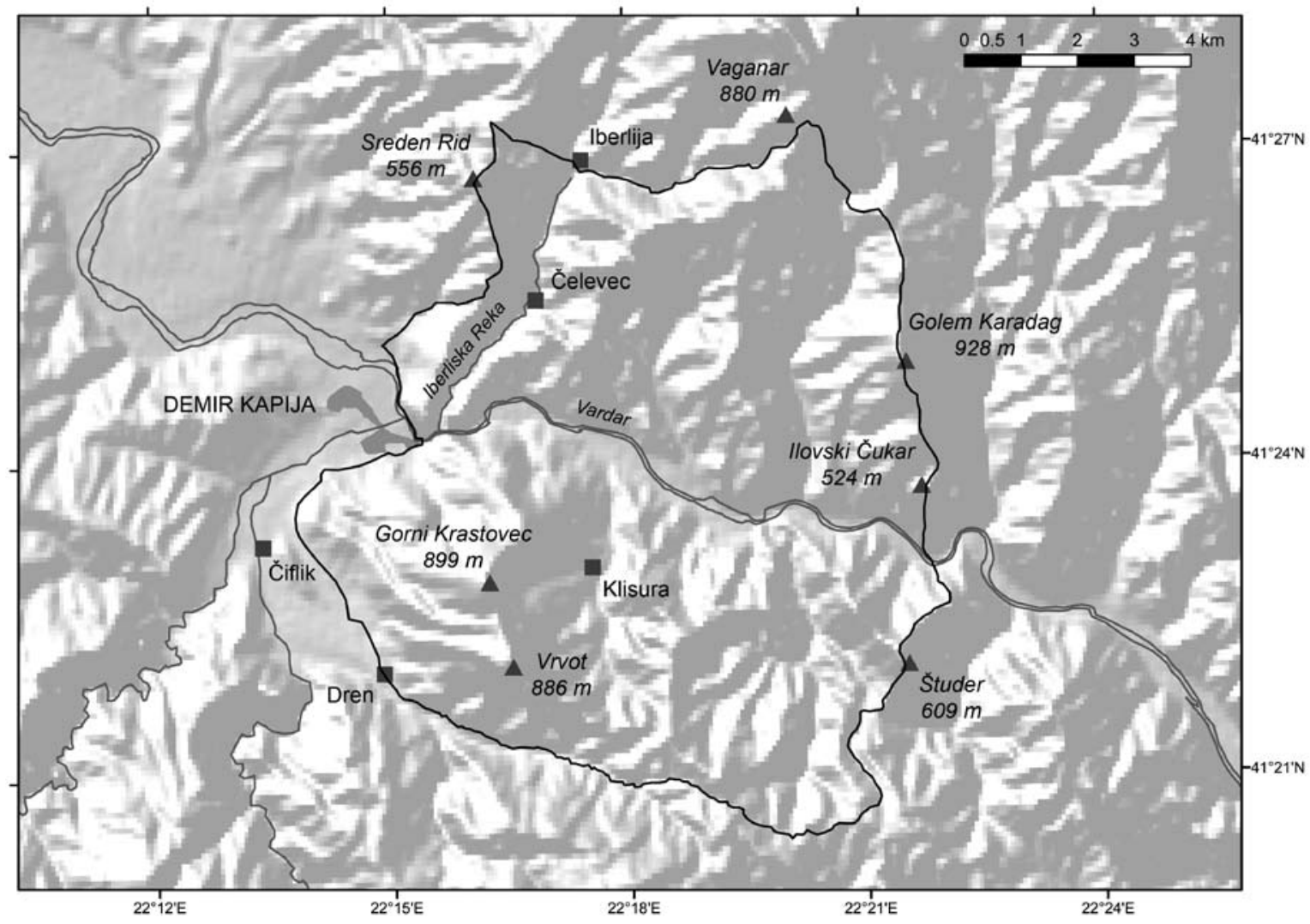

Figure 13: Map of the IBA Demir Kapija Gorge with its main features depicted

Slika 13: Zemljevid IBA Soteska Demir Kapija z glavnimi značilnostmi območja

\section{Species}

This location is best known by the birds of prey breeding on limestone cliffs, especially Griffon and Egyptian Vultures. Both had undergone strong decline; in 1996, their breeding populations were estimated at 16 and 10 pairs (GRUBAČ $1997 \&$ unpubl.), but numbered only six and two pairs in 2010, respectively. The Griffon Vulture colony there is one of the only three remaining breeding colonies in Macedonia. The total number of all registered bird species reached 149 (Rolevski et al. 2003). Today, the site is one of the five most important localities in the country for the Short-toed Eagle (5-8 pairs), whose breeding density with 0.5 pairs $/ 10 \mathrm{~km}^{2}$ is the highest in the country (VelevsKi \& GrubaČ 2008). Riparian Oriental Plane forests are very favourable for the breeding of the Levant Sparrowhawk (4-6 pairs). Among other species rarely found in Macedonia are the Booted Eagle, Black Kite, Black Stork, Longlegged Buzzard, etc. Most abundant among the
Table 21: The main CORINE land cover types (Level 3) in the IBA Demir Kapija Gorge

Tabela 21: Glavni tipi pokrovnosti in rabe tal (po CORINE land cover, 3. nivo) v IBA Soteska Demir Kapija

\begin{tabular}{llc}
\hline $\begin{array}{l}\text { Code/ } \\
\text { Koda }\end{array}$ & $\begin{array}{r}\text { CORINE land cover type/ } \\
\text { tip pokrovnosti in rabe tal }\end{array}$ & $\begin{array}{c}\text { Coverage/ } \\
\text { Pokrovnost (\%) }\end{array}$ \\
\hline 242 & Complex cultivation patterns & 5.7 \\
$3 \mathrm{II}$ & Broad-leaved forest & $2 \mathrm{I.6}$ \\
332 & Bare rocks & 0.3 \\
323 & Sclerophyllous vegetation & 34.8 \\
324 & Transitional woodland-shrub & 33.2 \\
& Other & 4.4 \\
\hline
\end{tabular}

species characteristic of the Mediterranean biome is the Subalpine Warbler (presumably one of the highest densities in the country) in the pseudomaquis, and the Rock Nuthatch on the limestone cliffs (Table 20). 
M. Velevski, B. Hallmann, B. Grubač, T. Lisičanec, E. Stoynov, E. Lisičanec, V. Avukatov, L. Božıč \& B. Stumberger: Important Bird Areas in Macedonia: Sites of Global and European Importance

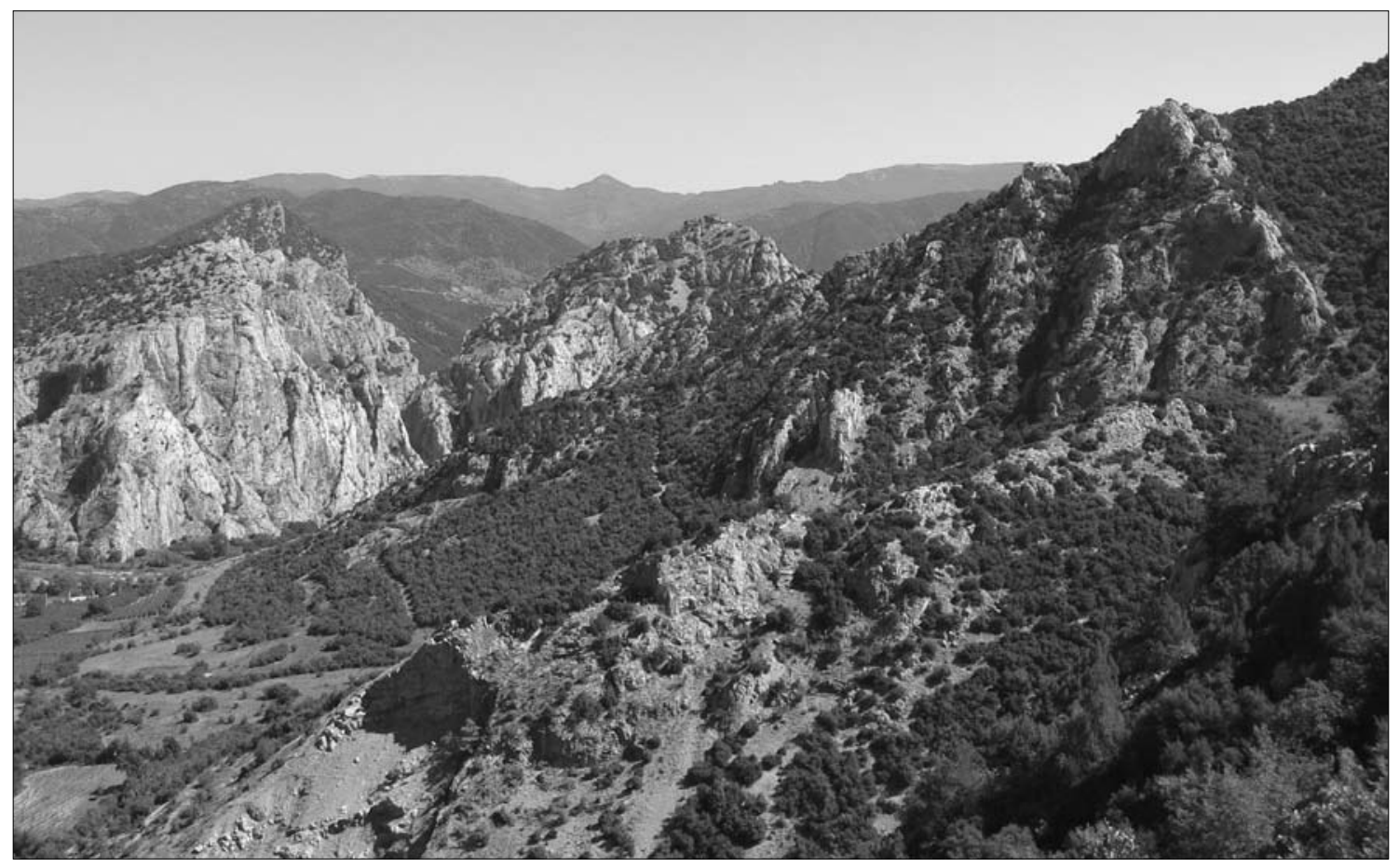

Figure 14: Characteristic landscape of the IBA Demir Kapija Gorge (photo: M. Velevski)

Slika 14: Značilna krajina IBA Soteska Demir Kapija (foto: M. Velevski)

Table 22: The main threats to birds and their importance in the IBA Demir Kapija Gorge

Tabela 22: Najpomembnejši dejavniki ogrožanja ptic in njihov vpliv v IBA Soteska Demir Kapija

\begin{tabular}{|c|c|c|c|}
\hline $\begin{array}{l}\text { Code/ } \\
\text { Koda }\end{array}$ & $\begin{array}{c}\text { Threat/ } \\
\text { Dejavnik ogrožanja }\end{array}$ & $\begin{array}{l}\text { Threat impact/ } \\
\text { Vpliv }\end{array}$ & $\begin{array}{l}\text { Most affected species/ } \\
\text { Najbolj prizadete vrste }\end{array}$ \\
\hline 243 & Trapping, poisoning, poaching & high & G. fulvus, N. percnopterus, A. chrysaetos, A. graeca \\
\hline I4I & Abandonment of pastoral systems & high & G. fulvus, N. percnopterus \\
\hline 230 & Hunting & high & G. fulvus, A. graeca \\
\hline 160 & General forestry management & medium & C. nigra, A. pennata, M. migrans, C. gallicus \\
\hline 502 & Motorways, roads & medium & G. fulvus, N. percnopterus, C. gallicus, A. brevipes \\
\hline 624 & Mountaineering, rock climbing, speleology & medium & G. fulvus \\
\hline 301 & Quarries & medium & C. gallicus, Mediterranean bird assemblage \\
\hline $4 \mathrm{IO}$ & Industrial or commercial areas & medium & $\begin{array}{l}\text { G. fulvus, } N \text {. percnopterus, A. chrysaetos, } \\
\text { C. gallicus, A. pennata }\end{array}$ \\
\hline 730 & Military manoeuvres & medium & G. fulvus \\
\hline 400 & Urbanised areas, human habitation & low & G. fulvus, A. chrysaetos, A. graeca \\
\hline
\end{tabular}

\section{Habitats and land use}

Limestone cliffs dominate the landscape, but degraded pseudomaquis with dominance of Kermes Oak Quercus coccifera is the prevailing forest community. At some locations, mature oak forests with significant presence of Silver Lime Tilia argentea are found, while along the Vardar and all smaller rivers, Oriental Plane Platanus orientalis belts are present (Table 21, Figure 14).

\section{Threats}

Hunting and poaching regularly take place, and use 
of poisonous baits was common until recently. Cliffs attract cliff-climbers, but are also used for military training. Depopulation of the villages resulted in a drastic decrease in livestock numbers, reducing food source for vultures. Illegal wood extraction for heating and construction purposes takes place along with official forest management practices. The reconstruction of E-75 highway from Skopje to Thessaloniki (Greece) is another serious threat the site will face in the near future. High disturbance is expected during the reconstruction phase, and somewhat less during the operation phase. Also, a plan for wind farm construction in the area has been prepared (Table 22).

\section{Conservation}

Part of the site is protected as a Nature Monument, but the protected site does not include some of the key localities. Also, parts of the valley of the Iberliska Reka River are under protection. It is proposed as an Emerald Site (MK0000005), but boundaries of this site have not been suitably defined as yet.

\subsubsection{Lake Dojran}

\section{General information}

Name in English: Lake Dojran

Name in Macedonian: Dojransko Ezero (Дојранско Езеро)

IBA code: $\mathrm{MK} 010$

Criteria: A1, A4i, B1i, B2

Area: 2,691 ha

Central coordinates: $22^{\circ} 44^{\prime} 3.00^{\prime \prime} \mathrm{E}, 41^{\circ} 12^{\prime} 51.81^{\prime \prime} \mathrm{N}$

Altitude: $150 \mathrm{~m}$ a.s.l.

Administrative region(s): Nov Dojran

\section{Site description}

The site is located in the SE part of the country, and includes the Macedonian part of Lake Dojran, together with the surrounding wetland vegetation. It adjoins the site "Lake Doirani" (GR023) in Greece (Heath \& Evans 2000).

The coast is limnogene, consisting of the lake sediments. It is a shallow tectonic lake with maximum depth of $10 \mathrm{~m}$ (Figure 15).

\section{Species}

The avifauna has been insufficiently studied; the complete list numbers only 84 waterbird species (MiceVsKi 2000, MiceVsKi 2002/2003, VeleVsKi \& Saveljić 2oio, Hanžel 20IO). However, for 12 species only single records are at hand. Data from winter censuses are available for the periods/years: 1982-1983, 1985, 1987-1990, 2002, and 20102011 (Micevski 199i, Wetlands International in litt., MES unpubl.). The total number of wintering waterbirds ranges from only 700 individuals in 2002, 3,200 in 2010, and up to 19,000 individuals in 1989. Most abundant are the Coot (between only 81 ind. in 2002 and 10,000 ind. in 1989), Pochard (up to 5,600 in 1990) and Tufted Duck (up to 3,000 in 1989). Of highest importance is the winter presence of Dalmatian Pelicans (330 ind. in 2002 and 450 in 2010) and Pygmy Cormorants (230 ind. in 1990). Other important species include $2-5$ breeding pairs of Ferruginous Duck (Micevski 2000), Bittern (at least two pairs, ŠKorpíkoví et al. 2006) and Little Bittern, whose breeding population has been estimated at a minimum of 30 pairs (MicevsKi 2000). A flock of min. 70 White Pelicans has been observed in spring 2010 (J. Hanžel pers. comm.). A single record of Redbreasted Goose Branta ruficollis exists (12 ind. on 14

Table 23: List of triggering and other important bird species in the IBA Lake Dojran

Tabela 23: Seznam kvalifikacijskih in drugih pomembnih ptic v IBA Dojransko jezero

\begin{tabular}{|c|c|c|c|c|c|}
\hline $\begin{array}{l}\text { Species/ } \\
\text { Vrsta }\end{array}$ & $\begin{array}{l}\text { Season/ } \\
\text { Sezona }\end{array}$ & $\begin{array}{l}\text { Year/ } \\
\text { Leto }\end{array}$ & $\begin{array}{l}\text { Population/ } \\
\text { Populacija }\end{array}$ & $\begin{array}{l}\text { Acc./ } \\
\text { Zan. }\end{array}$ & $\begin{array}{l}\text { Criteria/ } \\
\text { Kriteriji }\end{array}$ \\
\hline Pelecanus crispus & $\mathbf{W}$ & 2002-2010 & $300-450$ ind. & $\mathbf{A}$ & A1, A4i, B1i, B2 \\
\hline Ixobrychus minutus & $\mathbf{B}$ & 2000 & $30-60$ & B & B2 \\
\hline Botaurus stellaris & $\mathrm{B}$ & 2006 & $2-6$ & $\mathrm{~B}$ & B2? \\
\hline Pelecanus onocrotalus & $\mathrm{N}$ & 2010 & 70 ind. & A & $\mathrm{N}$ \\
\hline Phalacrocorax pygmeus & W & I988-2OII & $20-230$ ind. & A & $\mathrm{N}$ \\
\hline Aythya nyroca & $\mathrm{B}$ & 2000 & $2-5$ & $\mathrm{C}$ & $\mathrm{N}$ \\
\hline Aythya fuligula & W & 1987-1990 & $200-3,000$ ind. & A & $\mathrm{N}$ \\
\hline Fulica atra & W & I989-20II & $800-10,000$ ind. & A & $\mathrm{N}$ \\
\hline Aythya ferina & W & $1988-2002$ & $220-5600$ ind. & A & $\mathrm{N}$ \\
\hline
\end{tabular}


M. Velevski, B. Hallmann, B. Grubač, T. Lisičanec, E. Stoynov, E. Lisičanec, V. Avukatov, L. Božič \& B. Stumberger: Important Bird Areas in Macedonia: Sites of Global and European Importance

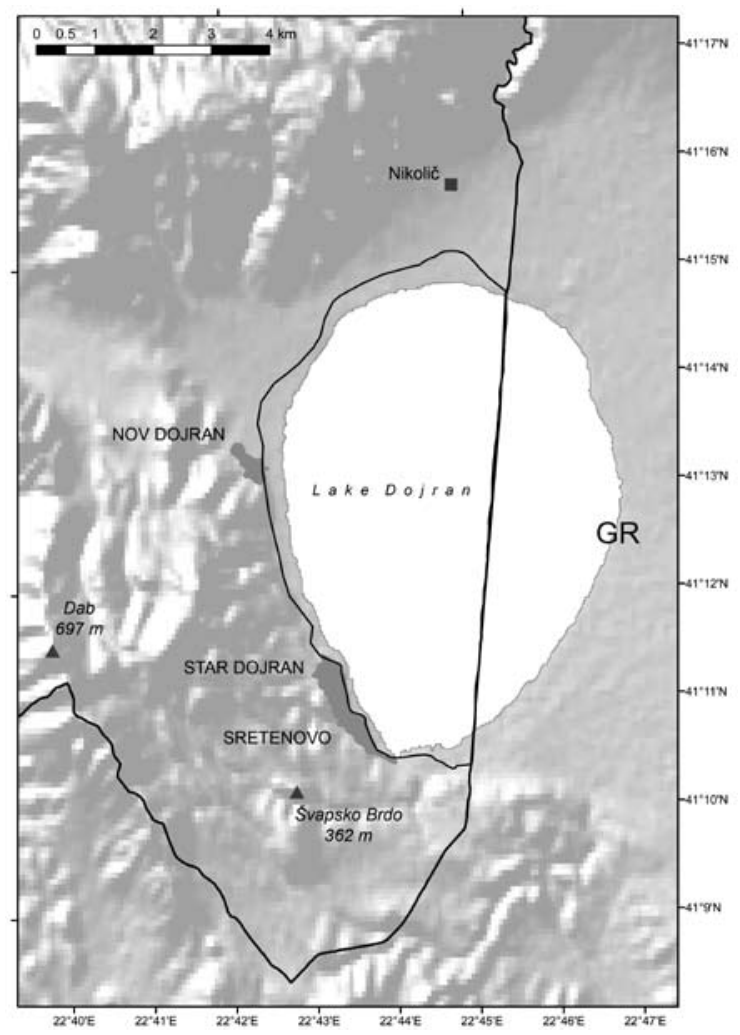

Figure 15: Map of the IBA Lake Dojran with the main features depicted

Slika 15: Zemljevid IBA Dojransko jezero z glavnimi značilnostmi območja

Feb 2003, E. Stoynov \& Y. ILIEv unpubl.), being only the second for the whole country (Table 23).

\section{Habitats and land use}

The lake surface constitutes the greater part of the IBA, with reedbeds along most of its shore included (Table 24). After withdrawal of the water during drying-up
Table 24: The main CORINE land cover types (Level 3) in the IBA Lake Dojran

Tabela 24: Glavni tipi pokrovnosti in rabe tal (po CORINE land cover, 3. nivo) v IBA Dojransko jezero

\begin{tabular}{llc}
\hline $\begin{array}{l}\text { Code/ } \\
\text { Koda }\end{array}$ & $\begin{array}{c}\text { CORINE land cover type/ } \\
\text { tip pokrovnosti in rabe tal }\end{array}$ & $\begin{array}{c}\text { Coverage/ } \\
\text { Pokrovnost }(\%)\end{array}$ \\
\hline 5I2 & Water bodies & 86.0 \\
4 II & Inland marshes & 9.7 \\
& Other & 4.4 \\
\hline
\end{tabular}

of the lake in the past, muddy shores were used for agriculture. The lake is eutrophic (Figure 16).

\section{Threats}

The lake was seriously threatened by drying out in the 1995-2002 period due to droughts and excessive water exploitation. Hydrological conditions have improved since, and supplementary water inflow has been secured, resulting in return of the water to the previous level. Intensive fishing, in which birds were formerly used, continues almost permanently (APOSTOLSKI \& Matvejev 1955). In the summer period, the lake is a popular tourist destination. A wind farm has been constructed on the Greek side of the Lake basin, probably impacting Dalmatian Pelicans and other waterbirds (Table 25).

\section{Conservation}

The lake is protected as a Nature Monument. It is a Ramsar Site of international importance owing to its significance for waterbird populations, and an Emerald Site (MK0000003). Apart from ensuring additional water inflow into the Lake, no other conservation activities are taking place here.

Table 25: The main threats to birds and their importance in the IBA Lake Dojran

Tabela 25: Najpomembnejši dejavniki ogrožanja ptic in njihov vpliv v IBA Dojransko jezero

\begin{tabular}{llcl}
\hline $\begin{array}{l}\text { Code/ } \\
\text { Koda }\end{array}$ & \multicolumn{1}{c}{$\begin{array}{c}\text { Threat/ } \\
\text { Dejavnik ogrožanja }\end{array}$} & $\begin{array}{c}\text { Threat impact/ } \\
\text { Vpliv }\end{array}$ & $\begin{array}{c}\text { Most affected species/ } \\
\text { Najbolj prizadete vrste }\end{array}$ \\
\hline 410 & Industrial or commercial areas & high & P. crispus \\
210 & Professional fishing & high & P. crispus, A. nyroca \\
600 & Sport and leisure structures & high & B. stellaris \\
\hline
\end{tabular}




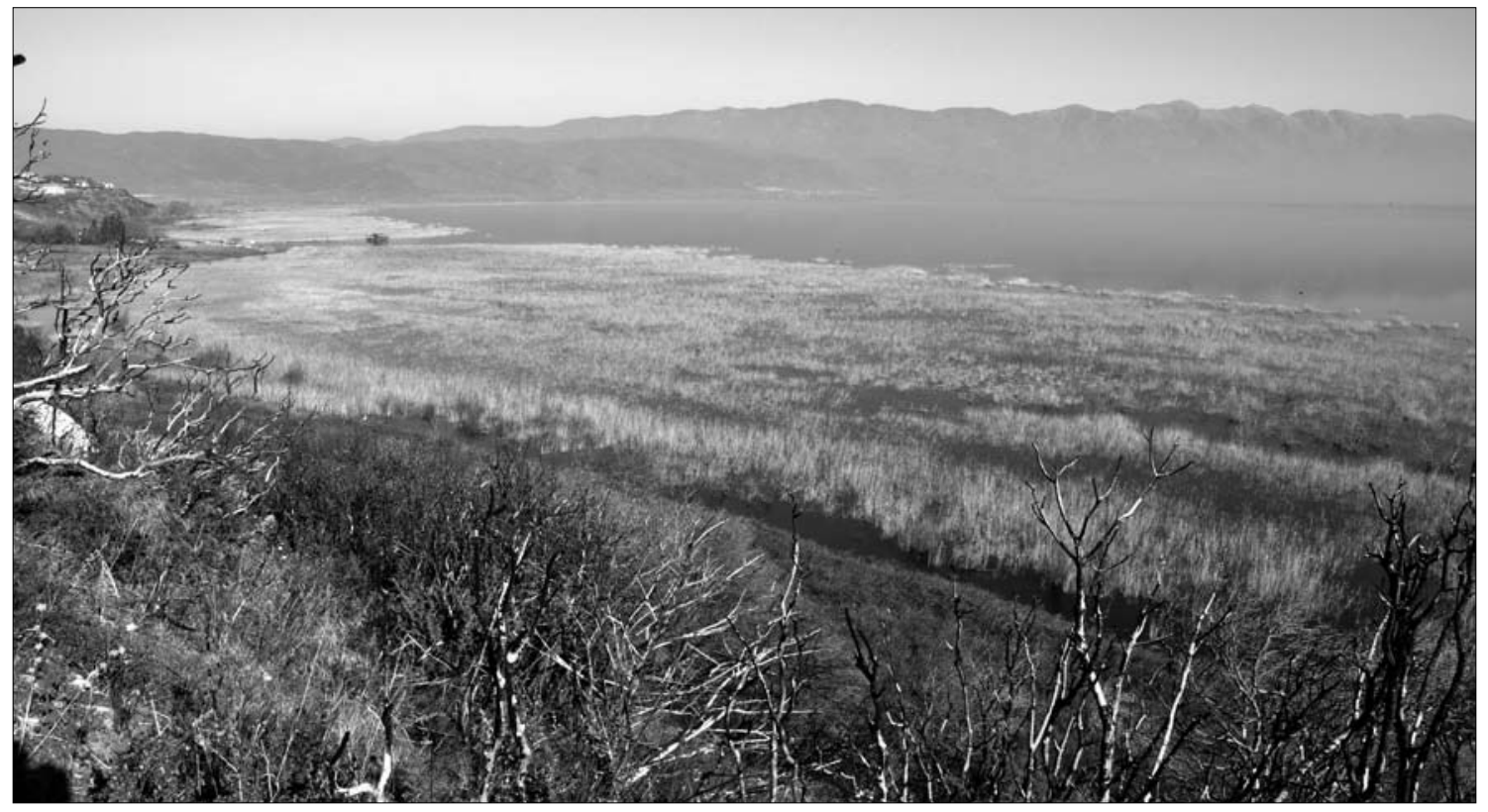

Figure 16: Characteristic landscape of the IBA Lake Dojran (photo: Ž. Brajanoski)

Slika 16: Značilna krajina IBA Dojransko jezero (foto: Ž. Brajanoski)

\subsubsection{Zletovska River Valley}

\section{General information}

Name in English: Zletovska River Valley

Name in Macedonian: Dolina na Zletovska Reka (Долина на Злетовска Река)

IBA code: $\mathrm{MK} 012$

Criteria: A1, B2

Area: 12,687 ha

Central coordinates: $22^{\circ} 10^{\prime} 25.28^{\prime \prime} \mathrm{E}, 41^{\circ} 55^{\prime} 52.66^{\prime \prime} \mathrm{N}$

Altitude: $310-867 \mathrm{~m}$ a.s.l.

Administrative region(s): Probištip, Češinovo - Obleševo, Kočani, Sveti Nikole

\section{Site description}

The site occupies the valley of the Zletovska Reka River south of the villages of Pišica and Novoselani, the SW slopes of Mt Osogovo and the eastern slopes of Mt Mangovica in NE Macedonia. Its SW boundary follows the ridge of Mangovica north of the village of Gorno Barbarevo, then continues SE to Petrišino village, passes the river valley at Globica village and proceeds east below the villages of Buneš and Rajčani, following the ridge formed by the peaks of Blatec (825 $\mathrm{m}$ a.s.l.), Božurnjak (767 $\mathrm{m}$ a.s.l.) and Uši (628 $\mathrm{m}$ a.s.1.), and descending SW to the village of Sokolarci. From there, it follows the irrigation channel

Table 26: List of triggering and other important bird species in the IBA Zletovska River Valley

Tabela 26: Seznam kvalifikacijskih in drugih pomembnih vrst v IBA Dolina Zletovske reke

\begin{tabular}{lccccc}
\hline $\begin{array}{l}\text { Species/ } \\
\text { Vrsta }\end{array}$ & $\begin{array}{c}\text { Season/ } \\
\text { Sezona }\end{array}$ & $\begin{array}{c}\text { Year/ } \\
\text { Leto }\end{array}$ & $\begin{array}{c}\text { Population/ } \\
\text { Populacija }\end{array}$ & $\begin{array}{c}\text { Acc./ } \\
\text { Zan. }\end{array}$ & $\begin{array}{c}\text { Criteria/ } \\
\text { Kriteriji }\end{array}$ \\
\hline $\begin{array}{l}\text { Aquila heliaca } \\
\text { Burhinus oedicnemus }\end{array}$ & $\mathbf{R}$ & $\mathbf{2 0 0 9}$ & $\mathbf{3 - 4}$ & $\mathbf{A}$ & $\mathbf{A 1 , ~ B 2}$ \\
Circus pygargus & $\mathrm{B}$ & 2008 & $5-20$ & $\mathrm{C}$ & $\mathrm{N}$ \\
Falco cherrug & $\mathrm{B}$ & 2008 & $3-\mathrm{IO}$ & $\mathrm{C}$ & $\mathrm{N}$ \\
Coracias garrulus & $\mathrm{B}$ & 2003 & $\mathrm{O}-\mathrm{I}$ & $\mathrm{A}$ & $\mathrm{N}$ \\
\hline
\end{tabular}


M. Velevski, B. Hallmann, B. Grubač, T. Lisičanec, E. Stoynov, E. Lisičanec, V. Avukatov, L. Božič \& B. Stumberger: Important Bird Areas in Macedonia: Sites of Global and European Importance

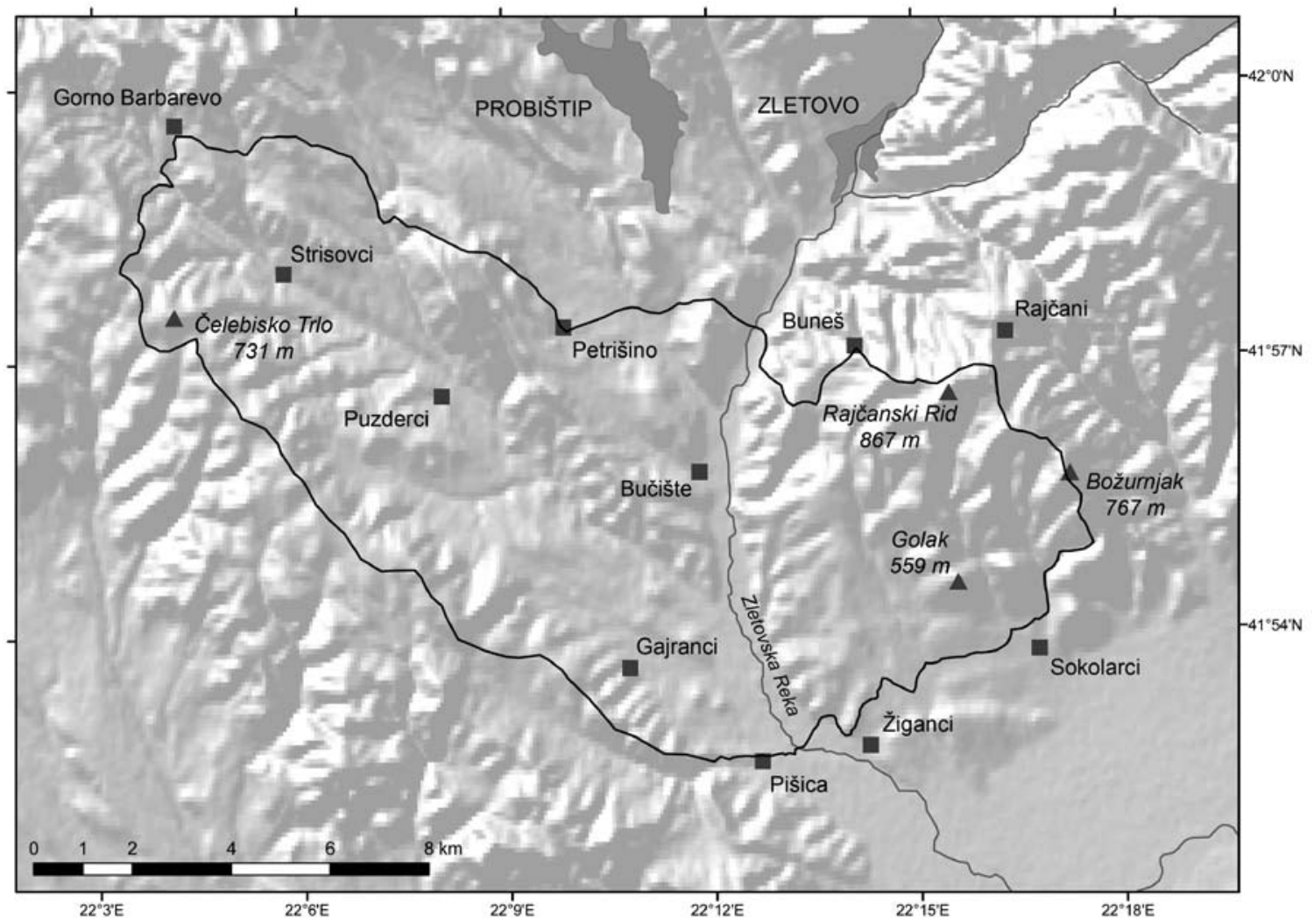

Figure 17: Map of the IBA River Zletovska valley with its main features depicted

Slika 17: Zemljevid IBA Dolina Zletovske reke z glavnimi značilnostmi območja

westwards to the village of Novoselani. The boundary has been largely modified from the original proposal by E. Stoynov from 2003 and excludes the rice fields along the Bregalnica River.

The site is characterized by low, undulating hilly and mountainous relief with dominant valley of the Zletovska Reka River and several intermittent streams in the western parts of the site. The geological composition is diverse, with magmatic rocks of Kratovo - Zletovo volcanic region and different metamorphic and alluvial sediments along the river (Figure 17).

\section{Species}

No detailed species list for the site is available, although ca. 80 species have been registered so far. Most important are the Imperial Eagle (3-4 pairs) and Stone Curlew (5-20 pairs), breeding on the hilly slopes with dry pastures and in remains of oak forests (Imperial Eagle), although the Roller (up to five breeding pairs) and a possible breeding of the Saker Falcon (one pair) have also been recorded.
Up to 10 pairs of Montagu's Harrier also breed here (Table 26).

Table 27: The main CORINE land cover types (Level 3) in the IBA Zletovska River Valley

Tabela 27: Glavni tipi pokrovnosti in rabe tal (po CORINE land cover, 3. nivo) v IBA Dolina reke Zletovske

\begin{tabular}{llc}
\hline $\begin{array}{l}\text { Code/ } \\
\text { Koda }\end{array}$ & $\begin{array}{c}\text { CORINE land cover type/ } \\
\text { tip pokrovnosti in rabe tal }\end{array}$ & $\begin{array}{c}\text { Coverage/ } \\
\text { Pokrovnost (\%) }\end{array}$ \\
\hline 2 II & Non-irrigated arable land & 34.0 \\
242 & Complex cultivation patterns & I8.0 \\
243 & Land principally occupied by & I0.9 \\
& agriculture, with significant & \\
& areas of natural vegetation & \\
231 & Pastures & I5.3 \\
324 & Transitional woodland-shrub & 17.8 \\
& Other & 3.9 \\
\hline
\end{tabular}




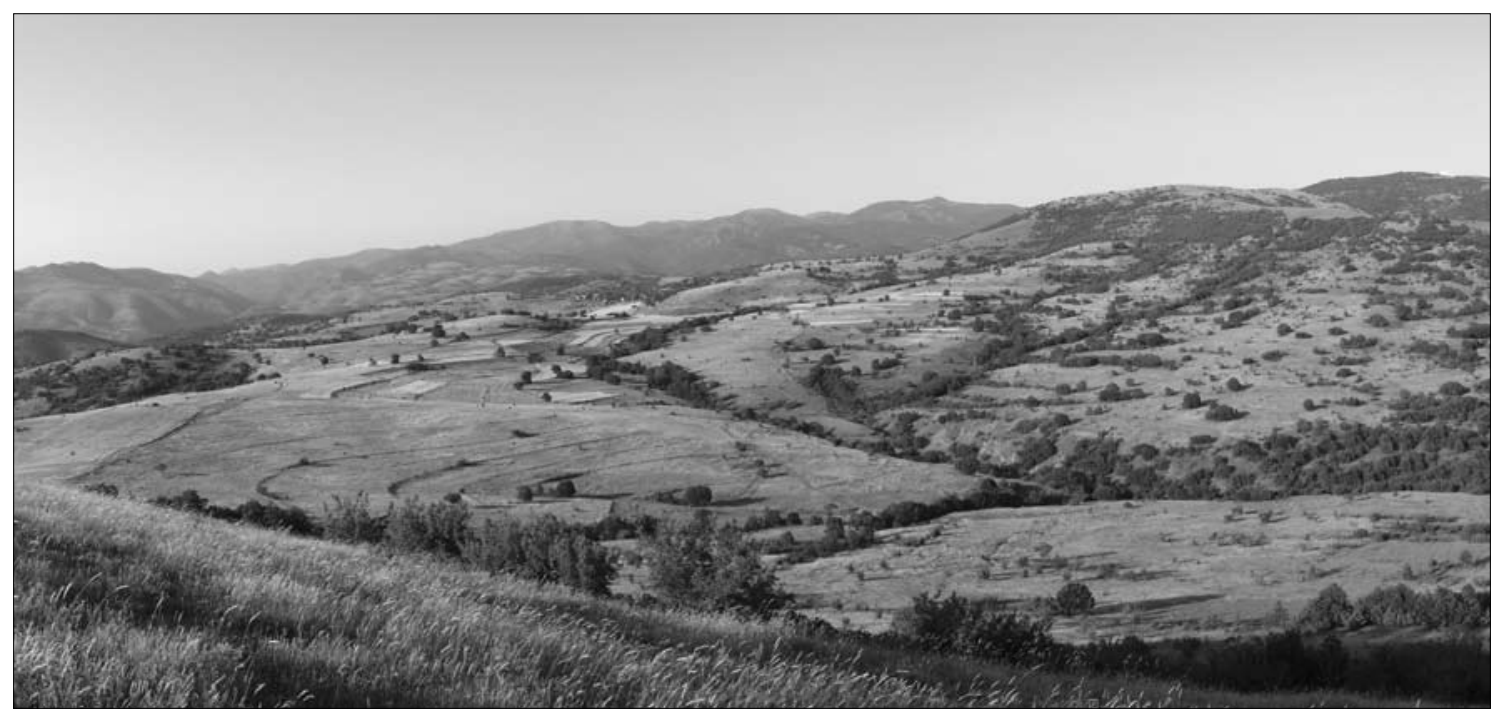

Figure 18: Characteristic landscape of the IBA Zletovska River Valley (photo: M. Velevski)

Slika 18: Značilna krajina v IBA Dolina Zletovske reke (foto: M. Velevski)

Table 28: The main threats to birds and their importance in the IBA Zletovska River Valley

Tabela 28: Najpomembnejši dejavniki ogrožanja ptic in njihov vpliv v IBA Dolina Zletovske reke

\begin{tabular}{llll}
\hline $\begin{array}{l}\text { Code/ } \\
\text { Koda }\end{array}$ & \multicolumn{1}{c}{$\begin{array}{c}\text { Threat/ } \\
\text { Dejavnik ogrožanja }\end{array}$} & $\begin{array}{c}\text { Threat impact/ } \\
\text { Vpliv }\end{array}$ & $\begin{array}{c}\text { Most affected species/ } \\
\text { Najbolj prizadete vrste }\end{array}$ \\
\hline I4I & Abandonment of pastoral systems & high & B. oedicnemus \\
243 & Trapping, poisoning, poaching & high & A. heliaca \\
IOI & Modification of cultivation practices & medium & C. ciconia \\
4IO & Industrial or commercial areas & medium & A. heliaca \\
\hline
\end{tabular}

\section{Habitats and land use}

The greater part of the lowland is used for agriculture, while the surrounding hills are typical dry pastures with remains of xerophylous oak forests, somewhat better preserved in the ravines. Poplar and willow belts have developed along the river (Table 27, Figure 18).

\section{Threats}

Threats are not well documented, but very likely include reduction of livestock numbers and poaching. Wind farm planned north of Sveti Nikole is also likely to affect Imperial Eagles breeding at this site.

\section{Conservation}

The site is not protected.

\subsubsection{Tikveš Region}

\section{General information}

Name in English: Tikveš Region

Name in Macedonian: Tikveški region

(Тиквешки регион)

IBA code: $\mathrm{MK} 013$

Criteria: A1, B2

Area: 18,696 ha

Central coordinates: $22^{\circ} 08^{\prime} 1.46^{\prime \prime} \mathrm{E}, 41^{\circ} 25^{\prime} 6.82^{\prime \prime N}$

Altitude: $160-855 \mathrm{~m}$ a.s.l.

Administrative region(s):

Negotino, Demir Kapija, Kavadarci

\section{Site description}

Site is situated in the southern-central parts of Macedonia, south of the town Negotino. The boundary 
M. Velevski, B. Hallmann, B. Grubač, T. Lisičanec, E. Stoynov, E. Lisičanec, V. Avukatov, L. Božič \& B. Stumberger: Important Bird Areas in Macedonia: Sites of Global and European Importance

starts at Pepelište village, crosses the Vardar, continues south to the village of Dolni Disan, then SW to the village of Moklište, continues along the road on the Vitačevo plateau to the crossroad towards the village of Stragovo, descends to this village, continues NE above the villages of Vešje and Besvica to the E-75 Skopje-Gevgelija highway, follows it east almost to Demir Kapija, crosses the Vardar and turns north to Korešnica village, then north to Široki Kuk, NW to the village of Brusnik and west back to the village of Pepelište (Figure 19).

The site is dominated by hills formed as a result of erosion that has shaped the bottom sediments of the Pliocene lake. The Vitačevo Plateau in the SW is composed of volcanogenic tuffs.

\section{Species}

The site classifies on the basis of two Egyptian Vulture pairs in its southern part and some 230-250 breeding pairs of Lesser Kestrel in the northern part, breeding exclusively in the villages. Northern part also includes the Vardar River Valley, where 1-2 pairs of Imperial Eagles breed. At least one pair of Lanner Falcon has been found, although there are indications that a second pair inhabits the area as well. Within this site, the dump site Dubrovo is situated, which formerly (I980-I99I period) attracted up to 120 individuals of Egyptian Vultures prior to their migration (B. GRUBAČ unpubl.), as well as a fishpond at the village of Bistrenci that presumably used to attract large numbers of migratory waterbirds. This fishpond has been dried out and converted into arable land; unfortunately, no systematic surveys of the bird fauna have ever

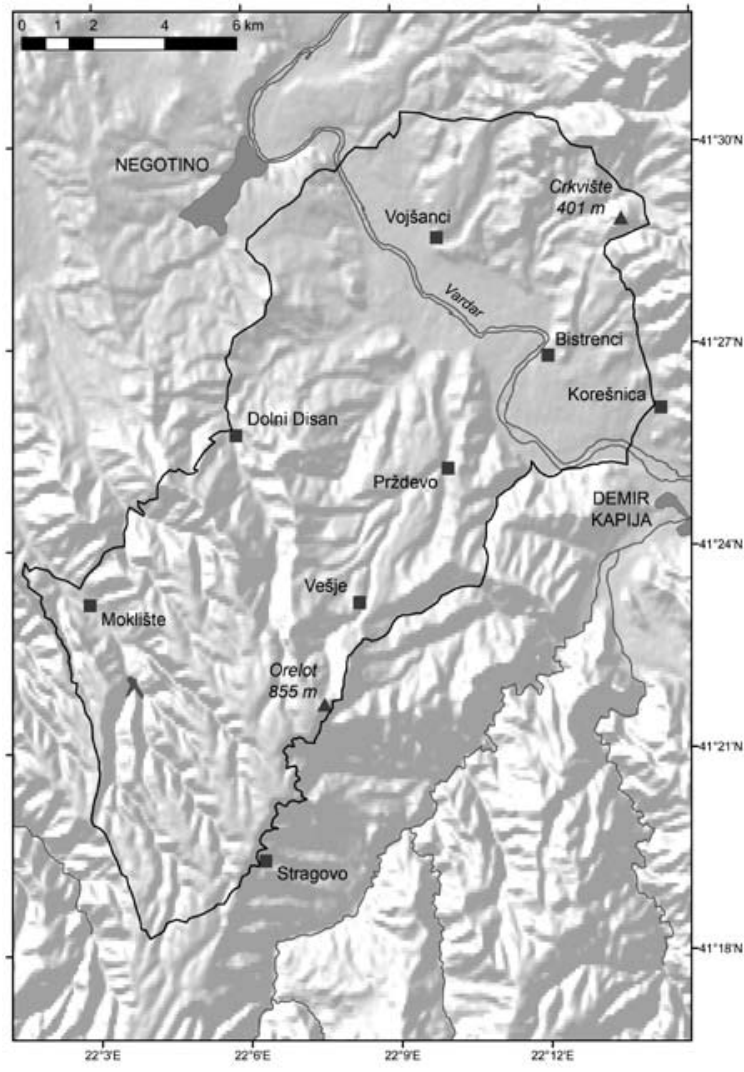

Figure 19: Map of the IBA Tikveš Region with its main features depicted

Slika 19: Zemljevid IBA Tikveško okrožje z glavnimi značilnostmi območja been carried out there. The site also holds the largest

Table 29: List of triggering and other important bird species in the IBA Tikveš Region

Tabela 29: Seznam kvalifikacijskih in drugih pomembnih vrst ptic v IBA Tikveško okrožje

\begin{tabular}{lccccc}
\hline Species/ & Season/ & Year/ & Population/ & Acc./ & Criteria/ \\
Vrsta & Sezona & Leto & Populacija & Zan. & Kriteriji \\
\hline Neophron percnopterus & $\mathbf{B}$ & $\mathbf{2 0 0 9}$ & $\mathbf{2}$ & $\mathbf{A}$ & $\mathbf{A 1}$ \\
Coracias garrulus & $\mathbf{B}$ & $\mathbf{2 0 0 9}$ & $\mathbf{5 - 1 5}$ & $\mathrm{C}$ & $\mathbf{A 1}$ \\
Falco naumanni & $\mathbf{B}$ & $\mathbf{2 0 0 3}$ & $\mathbf{2 3 0 - 2 5 0}$ & $\mathbf{B}$ & $\mathbf{B 2}$ \\
Accipiter brevipes & $\mathrm{B}$ & 2009 & $2-3$ & $\mathrm{C}$ & $\mathrm{B} 2$ ? \\
Buteo rufinus & $\mathrm{R}$ & 2010 & $2-4$ & $\mathrm{C}$ & $\mathrm{B} 2$ ? \\
Ardea cinerea & $\mathrm{B}$ & $200 \mathrm{I}-20 \mathrm{IO}$ & $60-90$ & $\mathrm{~A}$ & $\mathrm{~N}$ \\
Falco biarmicus & $\mathrm{B}$ & 2007 & $\mathrm{I}-2$ & $\mathrm{~B}$ & $\mathrm{~N}$ \\
Circaetus gallicus & $\mathrm{B}$ & 2008 & $3-5$ & $\mathrm{~B}$ & $\mathrm{~N}$ \\
Aquila heliaca & $\mathrm{R}$ & 2010 & $\mathrm{I}-2$ & $\mathrm{~B}$ & $\mathrm{~N}$ \\
Aquila chrysaetos & $\mathrm{R}$ & 2009 & $\mathrm{I}-2$ & $\mathrm{~A}$ & $\mathrm{~N}$ \\
Bubo bubo & $\mathrm{R}$ & 2009 & $2-4$ & $\mathrm{~B}$ & $\mathrm{~N}$ \\
\hline
\end{tabular}




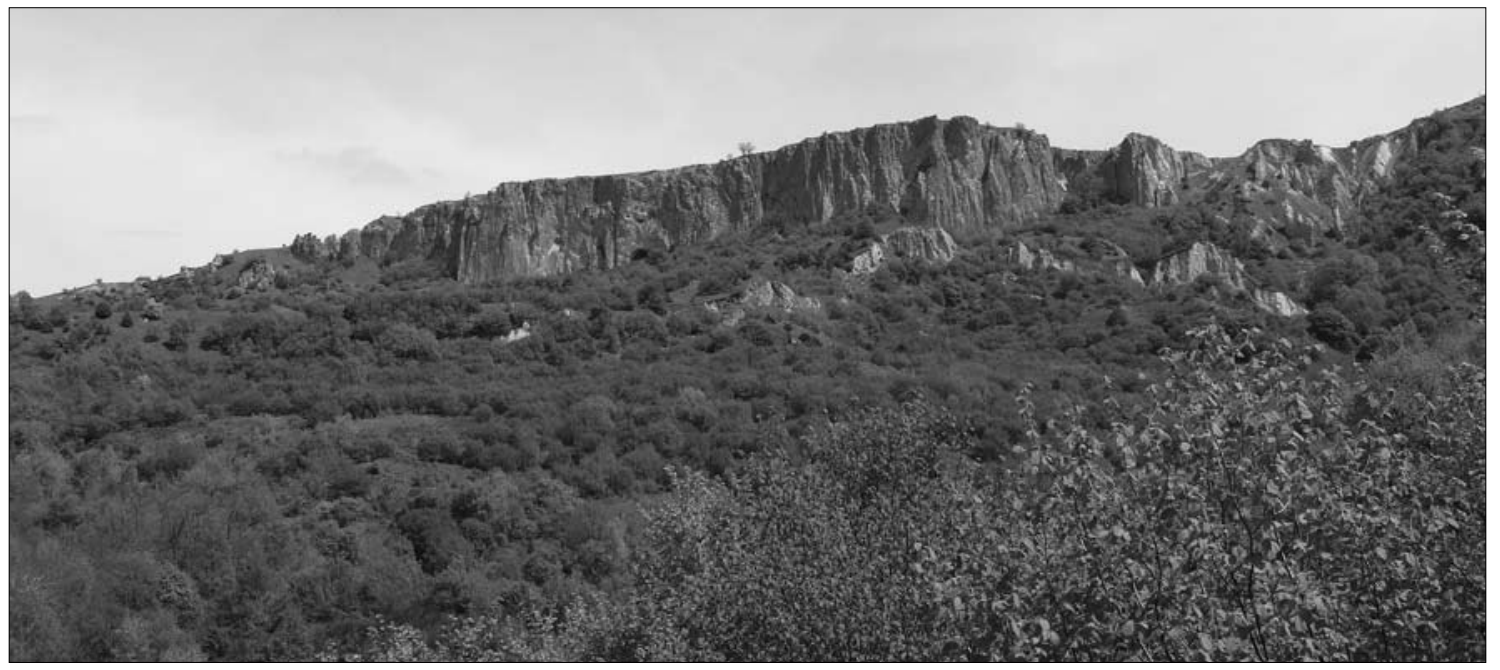

Figure 20: Characteristic landscape of the IBA Tikveš Region (photo: M. Velevski)

Slika 20: Značilna krajina IBA Tikveško okrožje (foto: M. Velevski)

national colony of Grey Heron Ardea cinerea (60-90 pairs) (Table 29).

\section{Habitats and land use}

The greater part of the site is used for agriculture - vineyards and orchards dominate, although dry pastures (steppe-like grasslands) and remains of oak scrubs are well-represented (Table 30, Figure 20).

\section{Threats}

Documented cases of Griffon Vultures Gyps fulvus being poisoned exist from the past, with the most prominent single event of poisoning taking place in 1993 at the Dubrovo dump site, when ca. 60-70 individuals of Egyptian Vultures were poisoned during deratization of the dump site just prior to their migration (GRUBAČ I997). Pesticide use is likely, as well as hunting; poaching is also present. Livestock
Table 30: The main CORINE land cover types (Level 3) in the IBA Tikveš Region

Tabela 30: Glavni tipi pokrovnosti in rabe tal (po CORINE land cover, 3. nivo) v IBA Tikveško okrožje

\begin{tabular}{llc}
\hline $\begin{array}{l}\text { Code/ } \\
\text { Koda }\end{array}$ & $\begin{array}{l}\text { CORINE land cover type/ } \\
\text { tip pokrovnosti in rabe tal }\end{array}$ & $\begin{array}{c}\text { Coverage/ } \\
\text { Pokrovnost (\%) }\end{array}$ \\
\hline $2 \mathrm{II}$ & Non-irrigated arable land & I4.0 \\
242 & Complex cultivation patterns & 29.0 \\
243 & Land principally occupied by & 9.2 \\
& agriculture, with significant & \\
& areas of natural vegetation & \\
$23 \mathrm{I}$ & Pastures & I3.0 \\
$22 \mathrm{I}$ & Vineyards & 7.8 \\
$32 \mathrm{I}$ & Natural grasslands & I4.0 \\
324 & Transitional woodland-shrub & $9 . \mathrm{I}$ \\
& Other & 4.0 \\
\hline
\end{tabular}

Table 31: The main threats to birds and their importance in the IBA Tikveš Region

Tabela 31: Najpomembnejši dejavniki ogrožanja ptic in njihov vpliv v IBA Tikveško okrožje

\begin{tabular}{llll}
\hline $\begin{array}{l}\text { Code/ } \\
\text { Koda }\end{array}$ & \multicolumn{1}{c}{$\begin{array}{c}\text { Threat/ } \\
\text { Dejavnik ogrožanja }\end{array}$} & $\begin{array}{c}\text { Threat impact/ } \\
\text { Vpliv }\end{array}$ & \multicolumn{1}{c}{$\begin{array}{c}\text { Most affected species/ } \\
\text { Najbolj prizadete vrste }\end{array}$} \\
\hline IIO & Use of pesticides & high & F. naumanni, C. garrulus \\
243 & Trapping, poisoning, poaching & high & A. heliaca, G. fulvus, $N$. percnopterus \\
I4I & Abandonment of pastoral systems & medium & F. naumanni, $N$. percnopterus, G. fulvus \\
5II & Electricity lines & medium & F. naumanni, A. heliaca, . garrulus \\
502 & Motorways, roads & medium & A. heliaca, C. garrulus, F. naumanni \\
\hline
\end{tabular}


M. Velevski, B. Hallmann, B. Grubač, T. Lisičanec, E. Stoynov, E. Lisičanec, V. Avukatov, L. Božič \& B. Stumberger: Important Bird Areas in Macedonia: Sites of Global and European Importance

breeding has decreased, very likely impacting vulture populations in the area (Table 31).

\section{Conservation}

Site is not protected, and no conservation measures are ongoing.

\subsubsection{Pčinja - Petrošnica - Kriva Reka Rivers}

\section{General information}

Name in English: Pčinja - Petrošnica - Kriva Reka Rivers

Name in Macedonian: Reka Pčinja - reka Petrošnica -

Kriva Reka (река Пчиња - река Петрошница - Крива Река)

IBA code: $\mathrm{MK} 014$

Criteria: A1, A3, B2

Area: 84,938 ha

Central coordinates: $21^{\circ} 55^{\prime} 48.62^{\prime \prime} \mathrm{E}, 42^{\circ} 10^{\prime} 2.20^{\prime \prime} \mathrm{N}$

Altitude: $280-1,355 \mathrm{~m}$ a.s.l.

Administrative region(s): Kumanovo, Staro Nagoričane, Kratovo, Probištip, Rankovce

\section{Site description}

Situated in the northern part of the country, this large IBA includes three geographically and ecologically different areas of significant ornithological value. Starting from the border with Serbia north of Kumanovo (near Sopot village), the boundary runs south avoiding the town of Kumanovo and its nearest villages, crosses the Pčinja River south this town (at the village of Pčinja), continues eastwards following the motorway from Kumanovo to Sveti Nikole and through villages of K'šanje and Tatomir, turns north below the peak of Gradište $(1,009$ $\mathrm{m}$ a.s.l.) and continues through Filipovci and Železnica villages near Kratovo. It continues north through the villages of Opila and Rankovce, and then turns NW, until passing through Arbanaško village and reaching the national border again. The site adjoins the site "Pcinja" in Serbia (SER025 in Heath \& Evans 2000, but RS036 in Puzović et al. 2009), forming a transboundary IBA.

The site embraces medium-size mountains, most dominant being Mt Kozjak in the north (summit

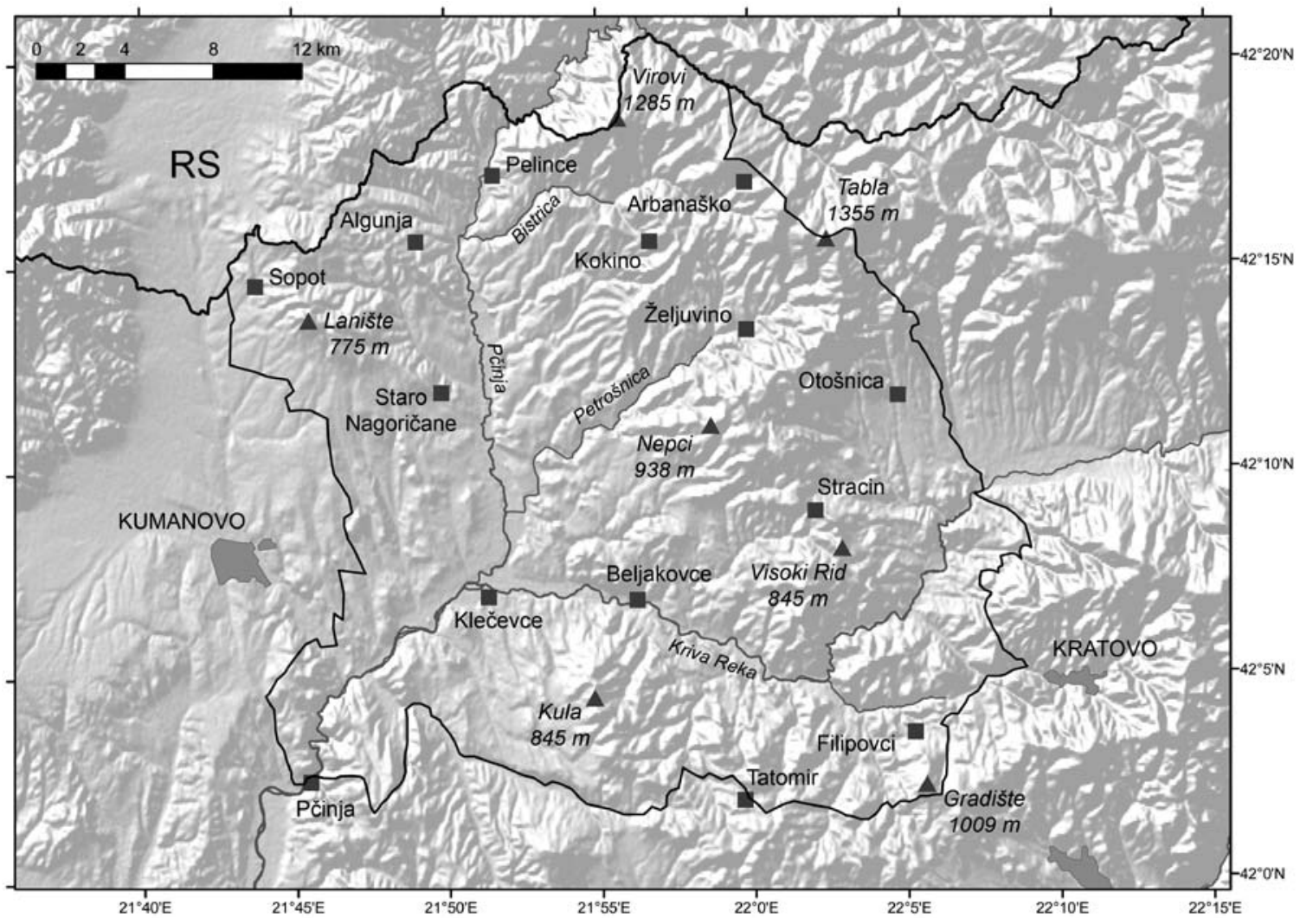

Figure 21: Map of the IBA Pčinja - Petrošnica - Kriva Reka Rivers with its main features depicted

Slika 21: Zemljevid IBA Reke Pčinja - Petrošnica - Kriva reka z glavnimi značinostmi območja 
Table 32: List of triggering and other important bird species in the IBA Pčinja - Petrošnica - Kriva Reka Rivers

Tabela 32: Seznam kvalifikacijskih in drugih pomembnih vrst v IBA Reke Pčinja - Petrošnica - Kriva reka

\begin{tabular}{|c|c|c|c|c|c|}
\hline $\begin{array}{l}\text { Species/ } \\
\text { Vrsta }\end{array}$ & $\begin{array}{l}\text { Season/ } \\
\text { Sezona }\end{array}$ & $\begin{array}{l}\text { Year/ } \\
\text { Leto }\end{array}$ & $\begin{array}{l}\text { Population/ } \\
\text { Populacija }\end{array}$ & $\begin{array}{l}\text { Acc./ } \\
\text { Zan. }\end{array}$ & $\begin{array}{l}\text { Criteria/ } \\
\text { Kriteriji }\end{array}$ \\
\hline Neophron percnopterus & B & 2008-2010 & $2-4$ & $\mathbf{A}$ & A1, B2 \\
\hline Aquila beliaca & $\mathbf{R}$ & 2010 & $4-6$ & $\mathbf{A}$ & A1, B2 \\
\hline Coracias garrulus & B & 2007 & $5-20$ & C & A1 \\
\hline Ficedula semitorquata & B & 2009 & $20-50$ & $\mathrm{C}$ & A1 \\
\hline Alectoris graeca & $\mathbf{R}$ & 2009 & $30-100$ & $\mathrm{C}$ & A3, B2 \\
\hline Lanius nubicus & B & 2008 & 10-30 & $\mathrm{C}$ & A3, B2 \\
\hline Oenanthe hispanica & B & & Frequent & & A3 \\
\hline Hippolais olivetorum & B & & Frequent & & A3 \\
\hline Sylvia cantillans & B & & Common & & A3 \\
\hline Sitta neumayer & $\mathbf{R}$ & & Common & & A3 \\
\hline Emberiza melanocephala & B & & Common & & A3 \\
\hline Ciconia nigra & B & 2008 & $3-4$ & A & B2 \\
\hline Circaetus gallicus & B & 2008 & $10-15$ & $\mathrm{C}$ & B2 \\
\hline Buteo rufinus & $\mathbf{R}$ & 2010 & $12-15$ & B & B2 \\
\hline Falco naumanni & B & 2010 & $10-50$ & $\mathrm{C}$ & B2 \\
\hline Falco biarmicus & B & 2009 & $3-4$ & B & B2 \\
\hline Bubo bubo & $\mathbf{R}$ & 2007 & 5-10 & $\mathrm{C}$ & $\mathbf{B 2}$ \\
\hline Falco vespertinus & $\mathrm{P}$ & 2008 & $5-50$ ind. & $\mathrm{C}$ & A1? \\
\hline Falco tinnunculus & $\mathrm{R}$ & & Common & & $\mathrm{B} 2$ ? \\
\hline Gyps fulvus & $\mathrm{N}$ & 2008 & $2-5$ ind. & $\mathrm{C}$ & $\mathrm{N}$ \\
\hline Aquila chrysaetos & $\mathrm{R}$ & 2010 & $\mathrm{I}-2$ & $\mathrm{C}$ & $\mathrm{N}$ \\
\hline Falco peregrinus & $\mathrm{R}$ & 2010 & $3-5$ & $\mathrm{C}$ & $\mathrm{N}$ \\
\hline Burhinus oedicnemus & B & $2 \mathrm{OII}$ & IO-2O & & $\mathrm{N}$ \\
\hline
\end{tabular}

Virovi 1,285 $\mathrm{m}$ a.s.l.), and the highest peaks towards $\mathrm{Mt}$ German in the east (Tabla summit $1,355 \mathrm{~m}$ a.s.l.). The geological composition is diverse, with predominating metamorphic rocks of different ages. Main rivers are the Kriva Reka with its tributary Kratovska Reka, and the Pčinja with the Bistrica and Petrošnica being its main tributaries (Figure 21).

\section{Species}

The mosaic landscape of steppe-like pastures and woods intersected with river valleys and small gorges attracts very large number of species, including raptors and seven species characteristic of the Mediterranean biome, some of which (Masked Shrike, Rock Nuthatch) reach here the northernmost part of their distribution areas in the Central Balkans. Large portions of the site have been insufficiently studied, making the estimate of population sizes difficult, and thus in most cases the figures given should be considered conservative. Some of the species (e.g. Egyptian Vulture, Imperial Eagle) have undergone a notable decline in the last decade (Grubač \& Velevski in prep.), but other important species seem to have increased in numbers, especially the Lesser Kestrel (10-50 pairs), for the first time recorded breeding in small colonies in the villages in 2010 (M. Ružıć pers. comm.). Notable is the breeding density of the Semicollared Flycatcher (20-50 pairs) in the northernmost parts of the site, reaching 6 pairs $/ 5$ ha in the remaining patches of mature Beech forests (ŠKORPíKOVÁ et al. 2009B), and further studies on distribution and population size of this species here are urgently needed. Other species that is likely to meet the thresholds set for populations of European importance is Common Kestrel. Small migrating flocks of Red-footed Falcons have also been observed (Table 32). Historically, breeding of Griffon Vultures has been recorded (B. Grubač unpubl.)

\section{Habitats and land use}

Very complex mosaic of habitat types is found at this site, from bare limestone cliffs in the gorges and bare silicate cliffs both in gorges and mountains, to old Beech and oak forests. Poplar and willow belts are found along all major rivers. Extensive arable fields 
M. Velevski, B. Hallmann, B. Grubač, T. Lisičanec, E. Stoynov, E. Lisičanec, V. Avukatov, L. Božıč \& B. Stumberger: Important Bird Areas in Macedonia: Sites of Global and European Importance

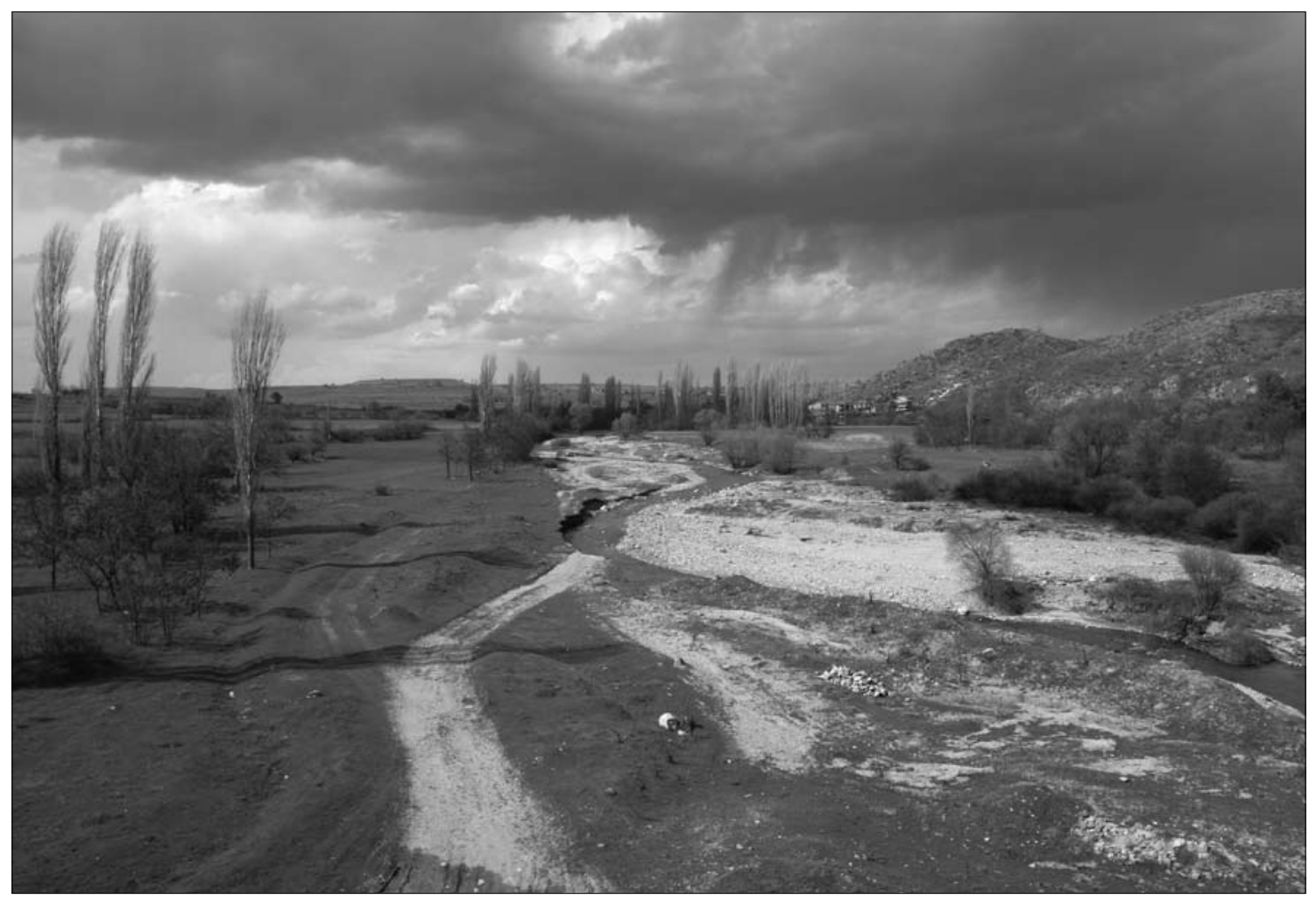

Figure 22: Characteristic landscape of the IBA Pčinja - Petrošnica - Kriva Reka Rivers (photo: B. Rubinić)

Slika 22: Značilna krajina IBA Reke Pčinja - Petrošnica - Kriva reka (foto: B. Rubinić)

and dry pastures are present, especially in the southern part of the site, while the northern part is dominated by oak forest remains on silicate, often exposed bedrock (Table 33, Figure 22).

Table 33: The main CORINE land cover types (Level 3) in the IBA Pčinja - Petrošnica - Kriva Reka Rivers

Tabela 33: Glavni tipi pokrovnosti in rabe tal (po CORINE land cover, 3. nivo) v IBA Reke Pčinja - Petrošnica - Kriva reka

\begin{tabular}{llc}
\hline $\begin{array}{l}\text { Code/ } \\
\text { Koda }\end{array}$ & $\begin{array}{l}\text { CORINE land cover type/ } \\
\text { tip pokrovnosti in rabe tal }\end{array}$ & $\begin{array}{c}\text { Coverage/ } \\
\text { Pokrovnost (\%) }\end{array}$ \\
\hline 2 II & Non-irrigated arable land & I5.0 \\
242 & Complex cultivation patterns & I7.5 \\
243 & Land principally occupied by & IO.4 \\
& agriculture, with significant & \\
& areas of natural vegetation & \\
23 I & Pastures & 28.5 \\
3 II & Broad-leaved forest & 8.2 \\
324 & Transitional woodland-shrub & I8.0 \\
& Other & 2.4 \\
\hline
\end{tabular}

\section{Threats}

Serious threat to the large raptors is the planned wind farm along the borderline with Serbia. Construction of railway and highway from Kumanovo to the Bulgarian border will possibly impact the breeding pairs of Imperial Eagles, Long-legged Buzzards, Black Stork, Lanner Falcon, and others. Forestry practices unfavourable to the Semicollared Flycatcher are likely. Hunting is widespread, poaching probably takes place, and occasional use of poisonous baits has been noted. Interest by falconers, especially in Lanner Falcon nests, exist, although no nest robbery has been documented so far. As in other regions of the country, livestock reduction has probably impacted vultures and Imperial Eagles (Table 34).

\section{Conservation}

Only an insignificant portion (less than 1\%) of the site has been protected within three separate sites (Orašac, Kuklica and Ploče - Litotelmi), on locations without significant importance for birds. Large part of the IBA overlaps the proposed Emerald Site "German - Pčinja" (MK0000029). 
Table 34: The main threats to birds and their importance in the IBA Pčinja - Petrošnica - Kriva Reka Rivers

Tabela 34: Najpomembnejši dejavniki ogrožanja ptic in njihov vpliv v IBA Reke Pčinja - Petrošnica - Kriva reka

\begin{tabular}{|c|c|c|c|}
\hline $\begin{array}{l}\text { Code/ } \\
\text { Koda }\end{array}$ & $\begin{array}{c}\text { Threat/ } \\
\text { Dejavnik ogrožanja }\end{array}$ & $\begin{array}{l}\text { Threat impact/ } \\
\text { Vpliv }\end{array}$ & $\begin{array}{l}\text { Most affected species/ } \\
\text { Najbolj prizadete vrste }\end{array}$ \\
\hline I4I & Abandonment of pastoral systems & high & N. percnopterus, F. naumanni, G. fulvus \\
\hline 243 & Trapping, poisoning, poaching & high & A. heliaca, N. percnopterus \\
\hline 230 & Hunting & medium & A. graeca \\
\hline 160 & General forestry management & medium & F. semitorquata \\
\hline 242 & Taking from nest (falcons) & medium & F. biarmicus \\
\hline $4 \mathrm{IO}$ & Industrial or commercial areas & medium & $N$. percnopterus, B. rufinus, $A$. chrysaetos, $F$. vespertinus \\
\hline 502 & Motorways, roads & medium & C. nigra, A. heliaca, F. biarmicus, B. rufinus \\
\hline 503 & Railway lines, TGV & medium & A. heliaca, B. rufinus, C. garrulus \\
\hline $70 I$ & Water pollution & medium & C. nigra \\
\hline
\end{tabular}

\subsubsection{Preod - Gjugjance}

\section{General information}

Name in English: Preod - Gjugjance

Name in Macedonian: Preod - Gjugjance (Преод Ѓуѓанце)

IBA code: $\mathrm{MK} 015$

Criteria: A1, B2

Area: 10,893 ha

Central coordinates: $21^{\circ} 58^{\prime} 9.22$ ”E, 41 ${ }^{\circ} 57^{\prime} 32.02^{\prime \prime} \mathrm{N}$

Altitude: $320-776 \mathrm{~m}$ a.s.l.

Administrative region(s): Sveti Nikole, Probištip,

Kumanovo

\section{Site description}

The site is situated in central Macedonia, north of the town Sveti Nikole. Starting from Nemanjica village, the boundary runs $\mathrm{NE}$ following the slopes of $\mathrm{Mt}$ Mangovica to the village Gorno Barbarevo. Part of this boundary is shared with the Zletovska River Valley site (MK012). From Gorno Barbarevo, the boundary turns west to Kokošinje village, and then continues S-SW to the villages of Stanjevci and Alakince, following the road Kumanovo-Sveti Nikole for a few kilometres. From Alakince, it roughly follows the $400 \mathrm{~m}$ isohypse to the village of Preod, from where it turns east to the village of Nemanjica again.

The site is characterized by low mountainous relief as part of Mt Mangovica, with geological composition dominated by metamorphite and magmatites, while lake sediments are found in the lower parts. The largest river is the Karataš (Figure 23).

\section{Species}

The site has been insufficiently studied, but 2-3 pairs of Imperial Eagle are found, breeding on the slopes of the hills and in the fields, together with 30-50 pairs of Lesser Kestrel breeding in the villages of the region. Rollers are also present, but their population was not censused. Other important species include Golden Eagle and possibly single pairs of Black Stork Ciconia nigra and Egyptian Vulture Neophron percnopterus (Table 35).

Table 35: List of triggering and other important bird species in the IBA Preod - Gjugjance

Tabela 35: Seznam kvalifikacijskih in drugih pomembnih vrst v IBA Preod - Gjugjance

\begin{tabular}{lccccc}
\hline $\begin{array}{l}\text { Species/ } \\
\text { Vrsta }\end{array}$ & Season/ & Year/ & Population/ & Acc./ & Criteria/ \\
Sezona & Leto & Populacija & Zan. & Kriteriji \\
\hline Aquila beliaca & $\mathbf{R}$ & $\mathbf{2 0 0 7}$ & $\mathbf{2 - 3}$ & $\mathbf{B}$ & $\mathbf{A 1}$ \\
Falco naumanni & $\mathbf{B}$ & $\mathbf{2 0 0 3}$ & $\mathbf{3 0 - 5 0}$ & $\mathbf{B}$ & $\mathbf{B 2}$ \\
Coracias garrulus & $\mathrm{B}$ & & Frequent & & $\mathrm{N}$ \\
Circus pygargus & $\mathrm{B}$ & 2010 & $3-\mathrm{O}$ & $\mathrm{B}$ & $\mathrm{N}$ \\
Aquila chrysaetos & $\mathrm{R}$ & 2010 & $\mathrm{I}$ & $\mathrm{A}$ & $\mathrm{N}$ \\
\hline
\end{tabular}




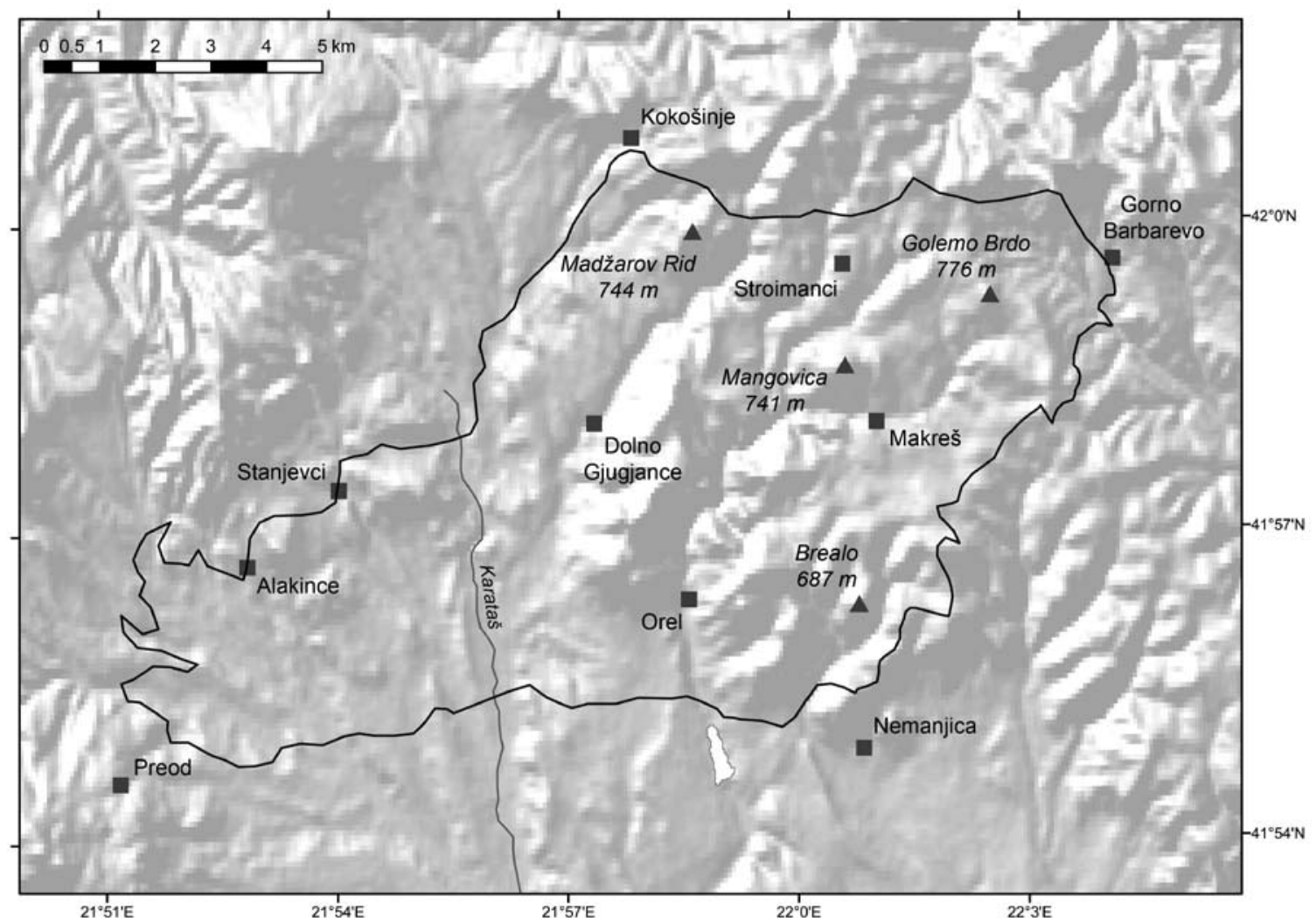

Figure 23: Map of the IBA Preod - Gjugjance with its main features depicted

Slika 23: Zemljevid IBA Preod - Gjugjance z glavnimi značinostmi območja

Table 36: The main CORINE land cover types (Level 3) in the IBA Preod - Gjugjance

Tabela 36: Glavni tipi pokrovnosti in rabe tal (po CORINE land cover, 3. nivo) v IBA Preod - Gjugjance

\begin{tabular}{llc}
\hline $\begin{array}{l}\text { Code/ } \\
\text { Koda }\end{array}$ & $\begin{array}{c}\text { CORINE land cover type/ } \\
\text { tip pokrovnosti in rabe tal }\end{array}$ & $\begin{array}{c}\text { Coverage/ } \\
\text { Pokrovnost }(\%)\end{array}$ \\
\hline $2 \mathrm{II}$ & Non-irrigated arable land & 25.4 \\
242 & Complex cultivation patterns & $\mathrm{I} 2.8$ \\
243 & $\begin{array}{l}\text { Land principally occupied by } \\
\text { agriculture, with significant }\end{array}$ & $\mathrm{I} 6.6$ \\
& areas of natural vegetation & \\
$23 \mathrm{I}$ & Pastures & $\mathrm{I} 8.9$ \\
$3 \mathrm{II}$ & Broad-leaved forest & 4.5 \\
324 & Transitional woodland-shrub & $2 \mathrm{I} .8$ \\
\hline
\end{tabular}

\section{Habitats and land use}

Agricultural arable land predominates, although wet meadows and pastures are also present in fairly high percentages. Remains of oak forests and windprotection tree-rows are found, on some places forming real forest stands (Table 36, Figure 24).

\section{Threats}

Wind farm development is planned in the near future within this region, which will also affect the sites of Zletovska River Valley (MK012) and Ovče Pole (MK019). Planned highway connecting Skopje with Štip will cross the site. Also, construction of a new cargo airport is foreseen in more distant future. Other threats are poorly documented. Electricity lines at the site have proved to be the cause of Lesser Kestrel mortalities due to electrocution, although other important species are likely to be affected as well. Livestock numbers have been greatly reduced in numbers, resulting in lower food availability for Imperial Eagles and foraging vultures, but also in overgrown pastures (i.e. breeding sites of Stone Curlew being lost) (Table 37).

\section{Conservation}

The site is not protected. 


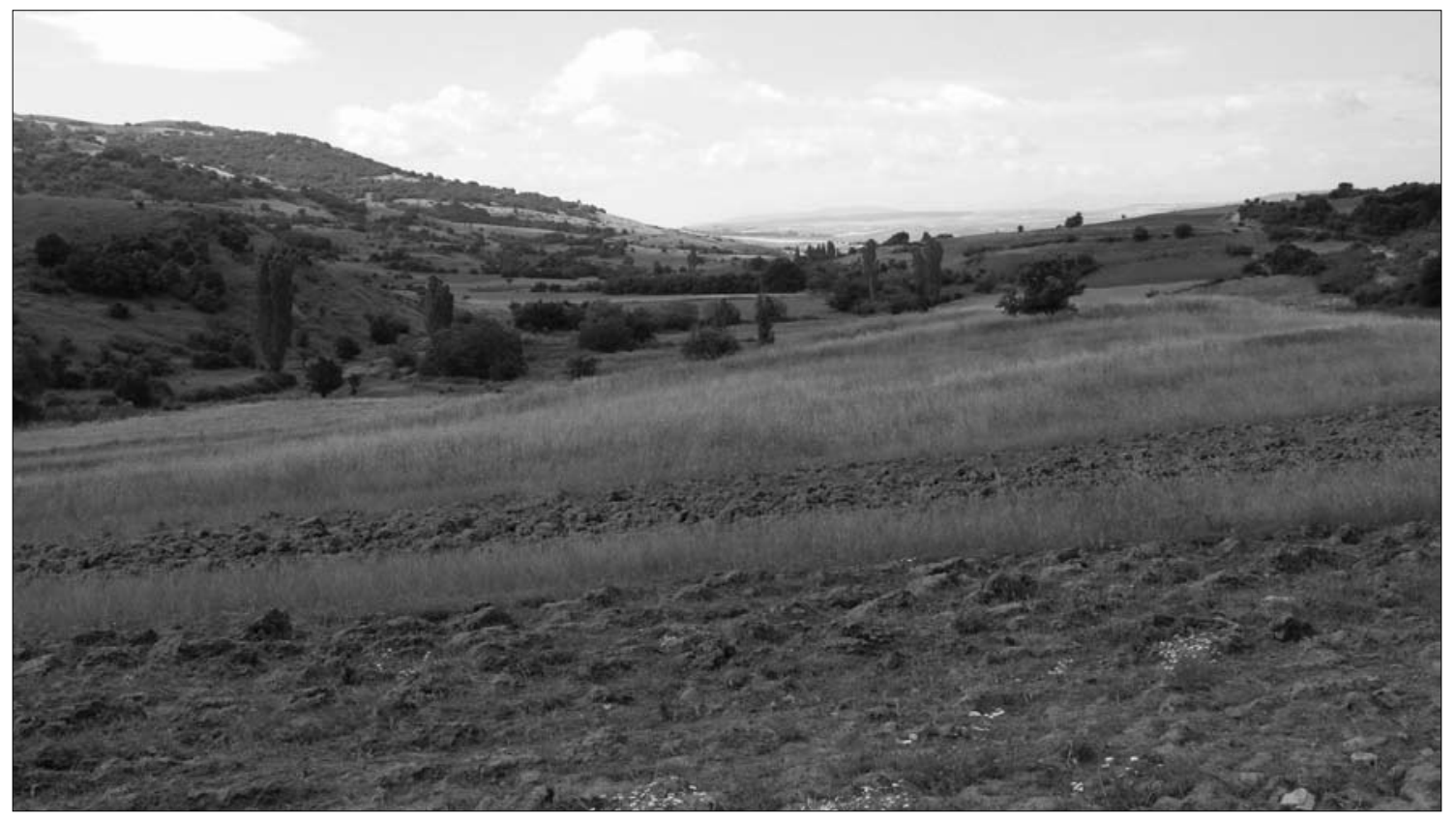

Figure 24: Characteristic landscape of the IBA Preod - Gjugjance (photo: M. Velevski)

Slika 24: Značilna krajina v IBA Preod - Gjugjance (foto: M. Velevski)

Table 37: The main threats to birds and their importance in the IBA Preod - Gjugjance

Tabela 37: Najpomembnejši dejavniki ogrožanja ptic in njihov vpliv v IBA Preod - Gjugjance

\begin{tabular}{llll}
\hline $\begin{array}{c}\text { Code/ } \\
\text { Koda }\end{array}$ & \multicolumn{1}{c}{$\begin{array}{c}\text { Threat/ } \\
\text { Dejavnik ogrožanja }\end{array}$} & $\begin{array}{c}\text { Threat impact/ } \\
\text { Vpliv }\end{array}$ & \multicolumn{1}{c}{$\begin{array}{c}\text { Most affected species/ } \\
\text { Najbolj prizadete vrste }\end{array}$} \\
\hline I4I & Abandonment of pastoral systems & high & F. naumanni \\
$5 \mathrm{II}$ & Electricity lines & high & A. heliaca, F. naumanni, C. garrulus \\
$4 \mathrm{IO}$ & Industrial or commercial areas & medium & A. heliaca, F. naumanni \\
$5 \mathrm{O} 2$ & Motorways, roads & medium & A. heliaca, F. naumanni, C. garrulus \\
505 & Airport & medium & A. heliaca, F. naumanni, C. garrulus \\
\hline
\end{tabular}

\subsubsection{Osogovo Mountains}

General information

Name in English: Osogovo Mountains

Name in Macedonian: Osogovski Planini

(Осоговски Планини)

IBA code: $\mathrm{MK} 016$

Criteria: A1, B2

Area: 7,530 ha

Central coordinates: $22^{\circ} 17^{\prime} 12.8^{\prime \prime} \mathrm{E}, 42^{\circ} 01^{\prime} 6.86^{\prime \prime} \mathrm{N}$

Altitude: 400-1,669 m a.s.l.

Administrative region(s): Probištip, Kočani, Kratovo

\section{Site description}

Situated east of the town Probištip in NE Macedonia, the site includes the lower western slopes of $\mathrm{Mt}$ Osogovo. Starting at the town Zletovo, the boundary runs east to the village of Tursko Rudare, to the locality Preslop, surrounds the Pasadžikova Čuka peak $(1,544$ $\mathrm{m}$ a.s.l.), continues north to the Ponikva ridges, west to Panagjur (1,669 $\mathrm{m}$ a.s.1.) and Kula (1,391 $\mathrm{m}$ a.s.l.), passes through the village Jamište, crosses the Zletovska Reka River and reaches Lukovo village, from where it continues south passing between the villages of Dobrevo and Lesnovo, reaching Zletovo again.

The relief is intersected by several river valleys, i.e. 
M. Velevski, B. Hallmann, B. Grubač, T. Lisičanec, E. Stoynov, E. Lisičanec, V. Avukatov, L. Božič \& B. Stumberger: Important Bird Areas in Macedonia: Sites of Global and European Importance

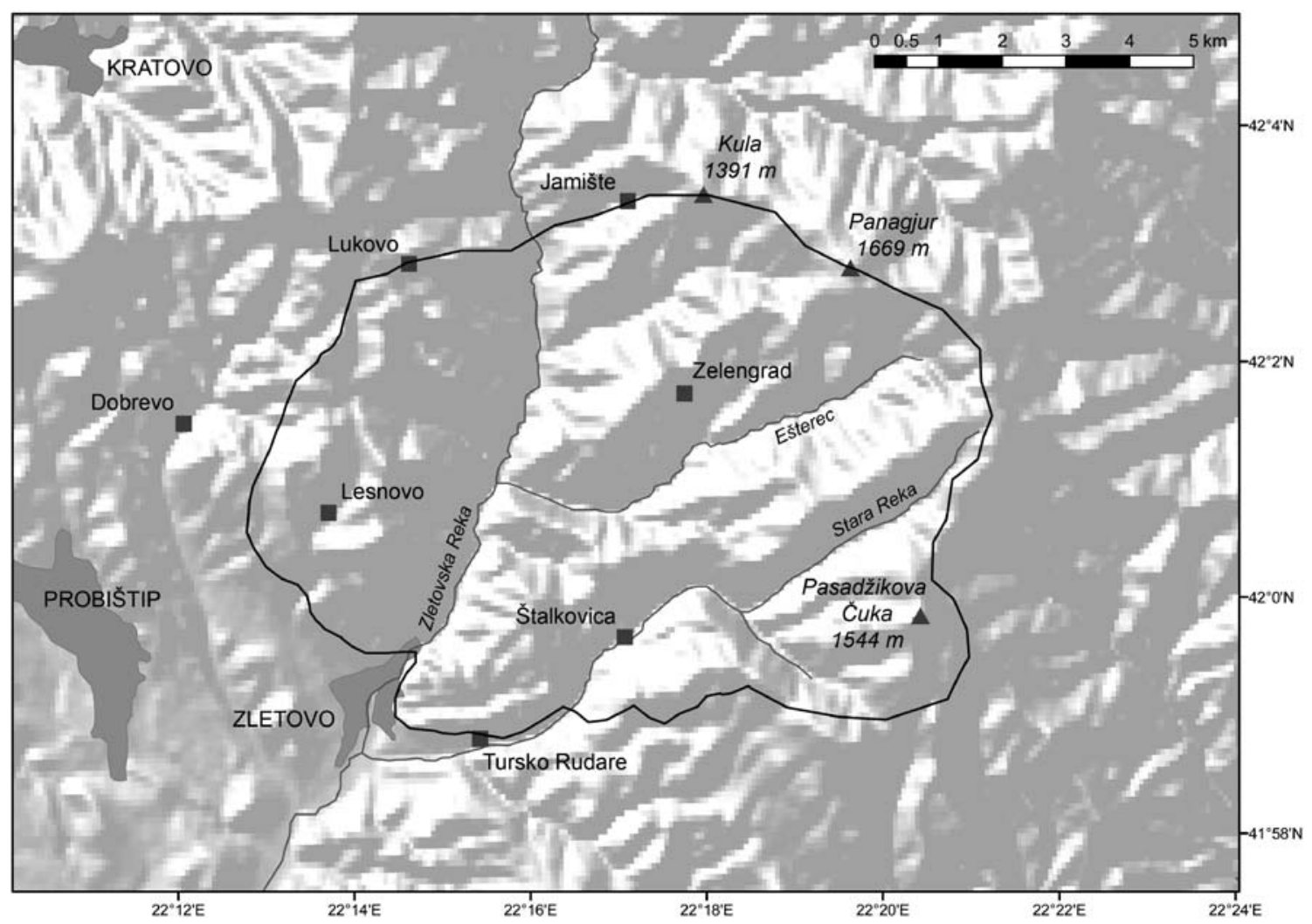

Figure 25: Map of the IBA Osogovo Mountains with its main features depicted

Slika 25: Zemljevid IBA Osogovsko gorovje z glavnimi značilnostmi območja

Zletovska Reka, Štalkovačka (Stara) Reka, Zelengradska Species

Reka, Jamiška Reka. The largest cliffs are those of Triggering species for the site are the Lanner Falcon Ratkova Skala (Stara Reka Gorge). Geologically, (two pairs) and Egyptian Vulture (one pair; in 1990s, magmatic rocks prevail in the region (Figure 25). four territories were known, B. GRuBAČ unpubl.). Two

Table 38: List of triggering and other important bird species in the IBA Osogovo Mountains

Tabela 38: Seznam kvalifikacijskih in drugih pomembnih ptic v IBA Osogovsko gorovje

\begin{tabular}{lccccc}
\hline $\begin{array}{l}\text { Species/ } \\
\text { Vrsta }\end{array}$ & $\begin{array}{c}\text { Season/ } \\
\text { Sezona }\end{array}$ & $\begin{array}{c}\text { Year/ } \\
\text { Leto }\end{array}$ & $\begin{array}{c}\text { Population/ } \\
\text { Populacija }\end{array}$ & $\begin{array}{c}\text { Acc./ } \\
\text { Zan. }\end{array}$ & $\begin{array}{c}\text { Criteria/ } \\
\text { Kriteriji }\end{array}$ \\
\hline Neophron percnopterus & $\mathbf{B}$ & $\mathbf{2 0 1 0}$ & $\mathbf{I}$ & $\mathbf{A}$ & $\mathbf{A 1}$ \\
Falco biarmicus & $\mathbf{B}$ & $\mathbf{2 0 0 7}$ & $\mathbf{2}$ & $\mathbf{A}$ & $\mathbf{B 2}$ \\
Ciconia nigra & $\mathrm{B}$ & 2008 & $\mathrm{I}$ & $\mathrm{A}$ & $\mathrm{N}$ \\
Circaetus gallicus & $\mathrm{B}$ & 2008 & 2 & $\mathrm{~A}$ & $\mathrm{~N}$ \\
Buteo rufinus & $\mathrm{B}$ & 2009 & $\mathrm{I}$ & $\mathrm{A}$ & $\mathrm{N}$ \\
Aquila chrysatos & $\mathrm{R}$ & 2008 & $\mathrm{I}$ & $\mathrm{A}$ & $\mathrm{N}$ \\
Falco peregrinus & $\mathrm{R}$ & 2008 & 3 & $\mathrm{~A}$ & $\mathrm{~N}$ \\
Alectoris graeca & $\mathrm{R}$ & & Frequent & $\mathrm{C}$ & $\mathrm{N}$ \\
Bubo bubo & $\mathrm{R}$ & 2008 & $\mathrm{I}-2$ & $\mathrm{C}$ & $\mathrm{C}$ \\
Ficedula semitorquata & $\mathrm{B}$ & 2009 & $\mathrm{O}-20$ & $\mathrm{C}$ & \\
\hline
\end{tabular}




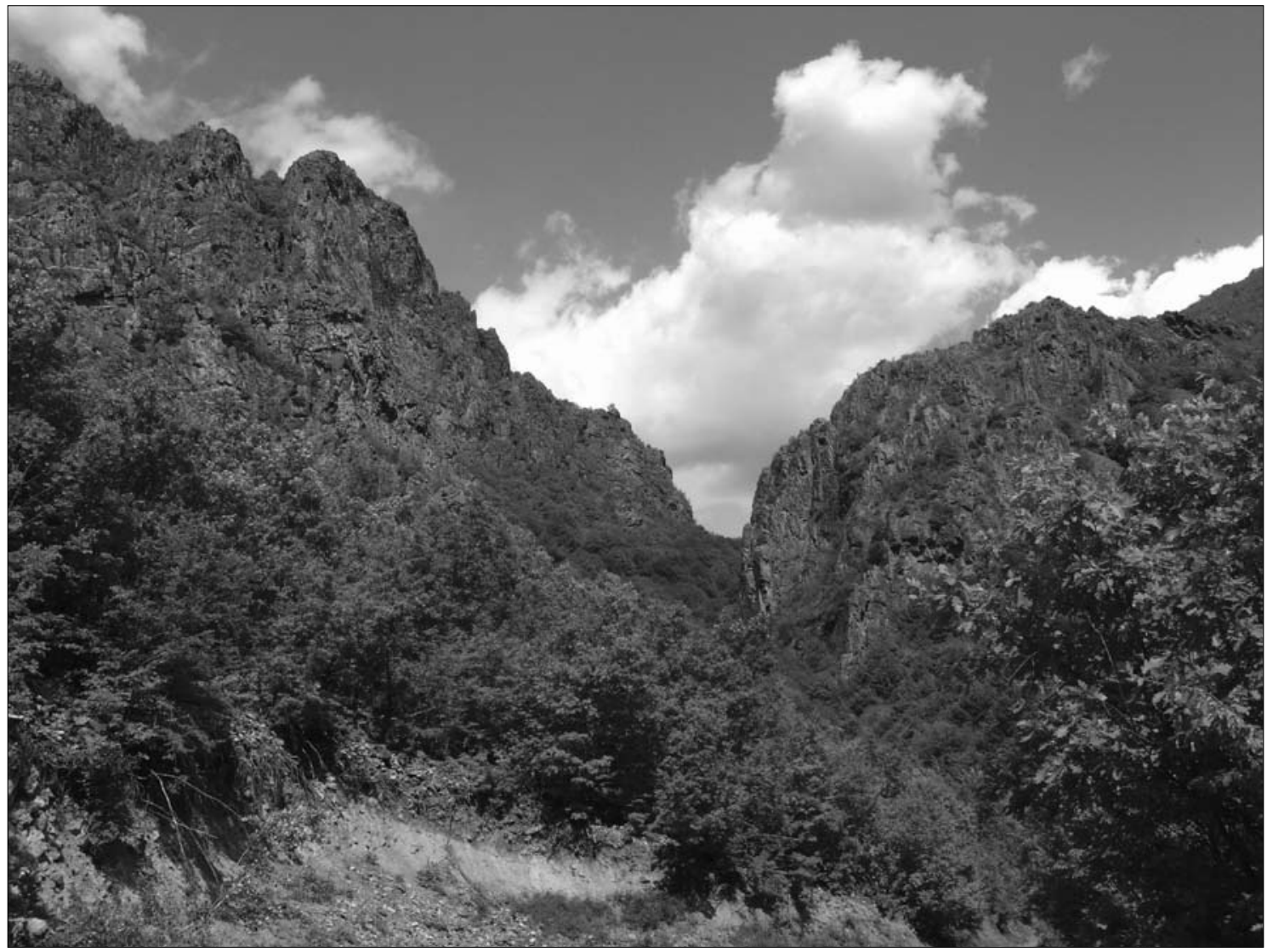

Figure 26: Characteristic landscape of the IBA Osogovo Mountains (photo: M. Velevski)

Slika 26: Značilna krajina IBA Osogovsko gorovje (foto: M. Velevski)

Table 39: The main CORINE land cover types (Level 3) in the IBA Osogovo Mountains

Tabela 39: Glavni tipi pokrovnosti in rabe tal (po CORINE land cover, 3. nivo) v IBA Osogovsko gorovje

\begin{tabular}{llc}
\hline $\begin{array}{l}\text { Code/ } \\
\text { Koda }\end{array}$ & $\begin{array}{l}\text { CORINE land cover type/ } \\
\text { tip pokrovnosti in rabe tal }\end{array}$ & $\begin{array}{c}\text { Coverage/ } \\
\text { Pokrovnost (\%) }\end{array}$ \\
\hline $23 \mathrm{I}$ & Pastures & 9.2 \\
$3 \mathrm{II}$ & Broad-leaved forest & 53.2 \\
324 & Transitional woodland-shrub & 26.8 \\
& Other & I0.8 \\
\hline
\end{tabular}

breeding pairs of Short-toed Eagle, 1-2 pairs of Eagle Owl, single pairs of Black Stork, Long-legged Buzzard and Golden Eagle, and three pairs of Peregrine Falcons have also been found. Semicollared Flycatcher has been recorded breeding at scattered localities on $\mathrm{Mt}$ Osogovo, although in numbers probably insufficient to include large territories of the mountain within the IBA's boundaries. The species has not yet been recorded within the site's boundaries, but is very likely present (Table 38). Until 2003, a small colony of Griffon Vultures used to breed here (E. STOYNov \& E. LisiČANEC, unpubl.).

\section{Habitats and land use}

The area is forested; oak and Beech forests alternate depending on the exposition. On some locations, forests are well preserved, with stands of mature trees present. The cliff complex, composed of several smaller and one dominant cliff, defines the landscape. The valley of Zletovska Reka River has a good deal of eroded surfaces and scrubs in different stages of succession (Table 39, Figure 26).

\section{Threats}

The local population is highly dependent on natural resources (pastures, forests) for survival, resulting in 
M. Velevski, B. Hallmann, B. Grubač, T. Lisičanec, E. Stoynov, E. Lisičanec, V. Avukatov, L. Božič \& B. Stumberger: Important Bird Areas in Macedonia: Sites of Global and European Importance

Table 40: The main threats to birds and their importance in the IBA Osogovo Mountains

Tabela 40: Najpomembnejši dejavniki ogrožanja ptic in njihov vpliv v IBA Osogovsko gorovje

\begin{tabular}{llll}
\hline $\begin{array}{c}\text { Code/ } \\
\text { Koda }\end{array}$ & \multicolumn{1}{c}{$\begin{array}{c}\text { Threat/ } \\
\text { Dejavnik ogrožanja }\end{array}$} & $\begin{array}{c}\text { Threat impact/ } \\
\text { Vpliv }\end{array}$ & \multicolumn{1}{c}{$\begin{array}{c}\text { Most affected species/ } \\
\text { Najbolj prizadete vrste }\end{array}$} \\
\hline I60 & General forestry management & high & F. semitorquata \\
242 & Taking from nest (falcons) & high & F. biarmicus, F. peregrinus \\
403 & Dispersed habitation & medium & C. nigra \\
502 & Motorways, roads & medium & C. nigra, N. percnopterus \\
301 & Quarries & medium & C. nigra, N. percnopterus, F. biarmicus, F. peregrinus \\
\hline
\end{tabular}

high timber extraction and collection of secondary forest products. Forestry is intensive, and clearcutting is frequently practiced. Mineral extraction took place in the past. A road connecting Zletovo with the "Ponikva" tourist locality is planned to pass through this site. Nest robbery (Lanner) has been noted (Table 40).

\section{Conservation}

Part of the site is managed as a hunting ground for big game, with limited access and thus under somewhat lesser pressure than the surrounding. The site completely falls within the borders of the Emerald Site (MK0000026) and the proposed protected area "Osogovo Mountains".

\subsubsection{Jakupica Mountain}

\section{General information \\ Name in English: Jakupica Mountain \\ Name in Macedonian: Jakupica (Јакупица) \\ IBA code: $\mathrm{MK} 017$ \\ Criteria: A3, B2 \\ Area: 23,081 ha \\ Central coordinates: $21^{\circ} 19^{\prime} 31.49^{\prime \prime} \mathrm{E}, 41^{\circ} 45^{\prime} 10.59^{\prime \prime} \mathrm{N}$ \\ Altitude: 470-2,539 $\mathrm{m}$ a.s.l. \\ Administrative region(s): Sopište, Studeničani, Čaška, Makedonski Brod, Želino}

\section{Site description}

This IBA occupies the highest parts of Mt Jakupica (most of the site lies above $1,600 \mathrm{~m}$ a.s.l.) in central Macedonia. Its boundary starts at Kula locality south of Skopje, descends into the Oča River Valley by following the road through the abandoned village of Kapina, then follows the Oča upstream and SE to the Jaloarnik locality, then follows the $1,200 \mathrm{~m}$ isohypse south to just above the village of Belica, then ascends to the isohypse of $1,600 \mathrm{~m}$. This isohypse forms almost

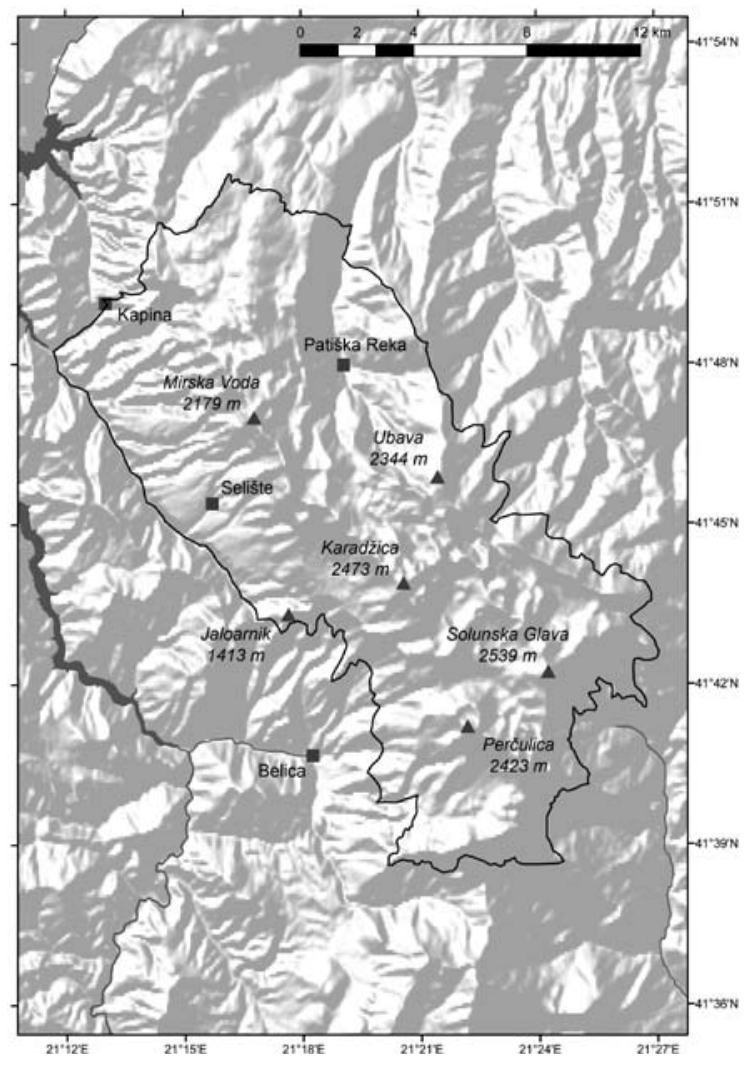

Figure 27: Map of the IBA Jakupica Mountain with its main features depicted

Slika 27: Zemljevid IBA Gora Jakupica z glavnimi značilnostmi območja

the entire southern boundary (except the Odbivarnik locality) and a large part of the eastern boundary to Kurtovica, where it ascends to $1,800 \mathrm{~m}$ a.s.l. Following this isohypse, the boundary continues north, to the saddle between Gorni and Dolni Pepeljak, follows the ridge Dolni Pepeljak and descends into the valley of 
Table 41: List of triggering and other important bird species in the IBA Jakupica Mountain

Tabela 41: Seznam kvalifikacijskih in drugih pomembnih vrst v IBA Gora Jakupica

\begin{tabular}{|c|c|c|c|c|c|}
\hline $\begin{array}{l}\text { Species/ } \\
\text { Vrsta }\end{array}$ & $\begin{array}{l}\text { Season/ } \\
\text { Sezona }\end{array}$ & $\begin{array}{l}\text { Year/ } \\
\text { Leto }\end{array}$ & $\begin{array}{c}\text { Population/ } \\
\text { Populacija }\end{array}$ & $\begin{array}{l}\text { Acc./ } \\
\text { Zan. }\end{array}$ & $\begin{array}{l}\text { Criteria/ } \\
\text { Kriteriji }\end{array}$ \\
\hline Prunella collaris & B & 2002 & $20-40$ & C & A3 \\
\hline Tichodroma muraria & B & 1999 & 5-10 & C & A3 \\
\hline Pyrrhocorax graculus & B & 2010 & $100-150$ & B & A3 \\
\hline Montifringilla nivalis & B & & Rare & & A3 \\
\hline Aquila chrysaetos & $\mathbf{R}$ & 1999 & $3-4$ & B & B2 \\
\hline Alectoris graeca & $\mathbf{R}$ & 2010 & 50-100 & $\mathrm{C}$ & B2 \\
\hline Falco tinnunculus & $\mathrm{R}$ & & Common & & B2? \\
\hline Falco peregrinus & $\mathrm{R}$ & 2010 & $2-3$ & C & $\mathrm{N}$ \\
\hline Bubo bubo & $\mathrm{R}$ & 2010 & $4-8$ & $\mathrm{C}$ & $\mathrm{N}$ \\
\hline Eremophila alpestris balcanica & B & & Frequent & & $\mathrm{N}$ \\
\hline Pyrrhocorax pyrrhocorax & B & & Frequent & & $\mathrm{N}$ \\
\hline
\end{tabular}

the Patiška Reka River. From here it turns west and near Kopanje reaches Kula again.

High mountain karst fields (Begovo Pole, Solunsko Pole, Silegarnik) are the area's main geomorphologic feature. The highest peaks are Karadžica $(2,473 \mathrm{~m}$ a.s.l.), Ubava $(2,344 \mathrm{~m}$ a.s.l.) and Solunska Glava Mts (2,539 $\mathrm{m}$ a.s.l.). Most prominent in the NW part are the cliffs of Mt Karadžica, while in the south the distinctive cliffs Nežilovski Steni are dominant. Geological composition is of Precambrian dolomites and dolomite marbles (Figure 27).

\section{Species}

Parts of the site have been well studied (within wider boundaries, except the western slopes), and about 120 species have been recorded so far (Dimovski 1967, VelevsKi et al. 2002B). The main reason for its designation are species characteristic of the Eurasian high-montane biome, found here in significant numbers, usually inhabiting the cliffs above 1,800 $\mathrm{m}$ a.s.l. This is the third most important site in the
Table 42: The main CORINE land cover types (Level 3) in the IBA Jakupica Mountain

Tabela 42: Glavni tipi pokrovnosti in rabe tal (po CORINE land cover, 3. nivo) v IBA Gora Jakupica

\begin{tabular}{llc}
\hline $\begin{array}{l}\text { Code/ } \\
\text { Koda }\end{array}$ & $\begin{array}{l}\text { CORINE land cover type/ } \\
\text { tip pokrovnosti in rabe tal }\end{array}$ & $\begin{array}{c}\text { Coverage/ } \\
\text { Pokrovnost (\%) }\end{array}$ \\
\hline 3 II & Broad-leaved forest & IO.7 \\
3 I2 & Coniferous forest & II.3 \\
313 & Mixed forest & I0.7 \\
332 & Bare rocks & 0.7 \\
$32 \mathrm{I}$ & Natural grasslands & 49.9 \\
322 & Moors and heathland & 2.6 \\
324 & Transitional woodland-shrub & I2.7 \\
& Other & I.4 \\
\hline
\end{tabular}

country after Šar Planina Mountain (MK001) and the Radika River Catchment (MK002). From this group of birds, presence of the Snowfinch, a very rare

Table 43: The main threats to birds and their importance in the IBA Jakupica Mountain

Tabela 43: Najpomembnejši dejavniki ogrožanja ptic in njihov vpliv v IBA Gora Jakupica

\begin{tabular}{llll}
\hline $\begin{array}{l}\text { Code/ } \\
\text { Koda }\end{array}$ & \multicolumn{1}{c}{$\begin{array}{c}\text { Threat/ } \\
\text { Dejavnik ogrožanja }\end{array}$} & $\begin{array}{c}\text { Threat impact/ } \\
\text { Vpliv }\end{array}$ & $\begin{array}{c}\text { Most affected species/ } \\
\text { Najbolj prizadete vrste }\end{array}$ \\
\hline I4I & Abandonment of pastoral systems & high & P. graculus \\
243 & Trapping, poisoning, poaching & high & A. chrysaetos \\
960 & Interspecific faunal relations & high & A. chrysaetos, B. bubo \\
230 & Hunting & medium & A. graeca \\
\hline
\end{tabular}


M. Velevski, B. Hallmann, B. Grubač, T. Lisičanec, E. Stoynov, E. Lisičanec, V. Avukatov, L. Božič \& B. Stumberger: Important Bird Areas in Macedonia: Sites of Global and European Importance

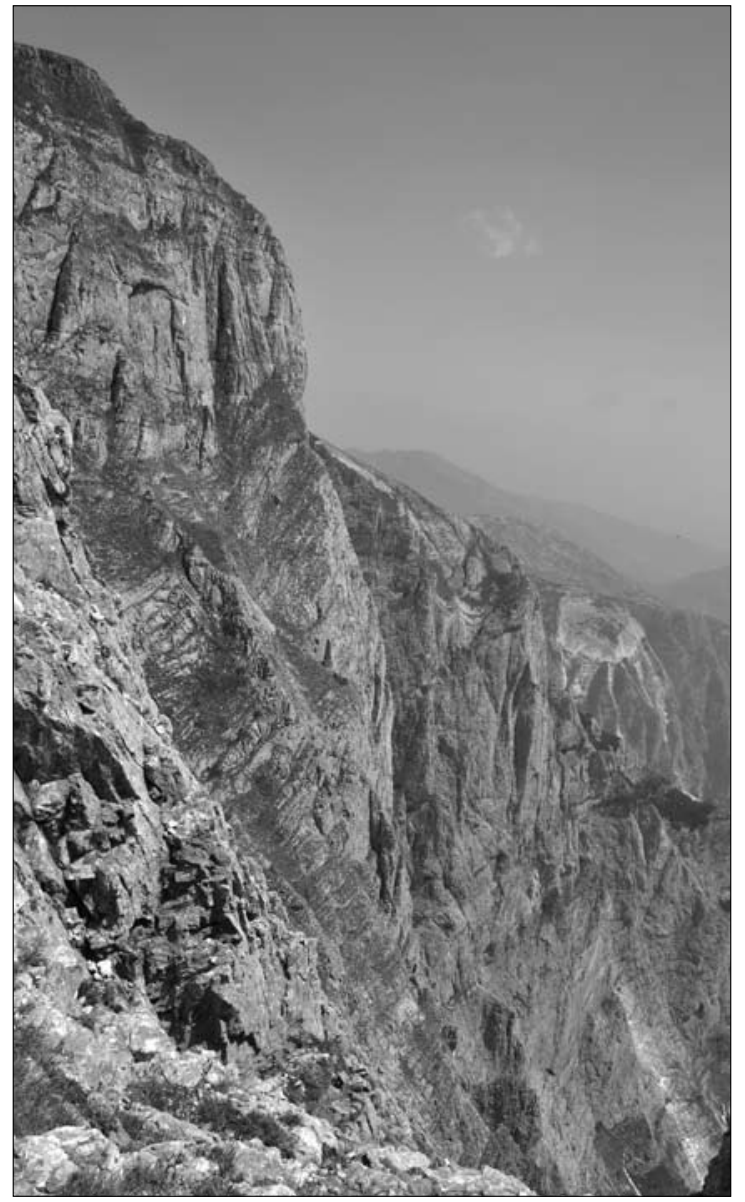

Figure 28: Characteristic landscape of the IBA Jakupica Mountain (photo: S. Hristovski)

Slika 28: Značilna krajina v IBA Gora Jakupica (foto: S. Hristovski)

species here, has also been recorded (Dimovski 1967 , MatvejeV 1976). Although it has not been recorded since then, we have included it in the list. The site also holds important populations of Red-billed Chough and Shore Lark. Golden Eagle population (3-4 pairs) meets the threshold of European importance. The site holds internationally important population of Rock Partridge (50-100 pairs), and probably Common Kestrel, but their relative importance against other sites in Macedonia is unknown (Table 41).

\section{Habitats and land use}

Alpine pastures, moors, some heathland and large rocky karst fields dominate above the tree zone, with limestone cliff-faces descending steep into the forests (Beech Fagus sylvatica in the south, European Black
Pine Pinus nigra in the west). Large complexes of Mountain Pine Pinus mugo are found in the northern part of the site. Beech forest is the dominant broadleaved forest, often mixed with Bulgarian Fir Abies borisii-regis or Black Pine (Table 42, Figure 28).

\section{Threats}

Apart from hunting and poaching, further resulting in the reduction of raptor prey base, no other direct threats have been recorded. Livestock breeding has significantly decreased, probably impacting populations of Choughs and large raptors (Table 43).

\section{Conservation}

The site is partially included in the Multipurpose protected area "Jasen", which due to its intensive management and significant conservation efforts reduces the threats from hunting and poaching (even though controlled hunting activities are implemented by the "Jasen" management). Small parts of the site are included in the "Belešnička Reka" Nature Monument. A small protected area for the conservation of Mountain Pine (Juričica) was also designated within the site. Designation of a new national park, "Jakupica", is planned, which is to include the remaining territory. The site is entirely included in the "Jakupica" Emerald Site (MK0000017).

\subsubsection{Taor Gorge}

\author{
General information \\ Name in English: Taor Gorge \\ Name in Macedonian: Taorska Klisura (Таорска \\ Клисура) \\ IBA code: $\mathrm{MK} 018$ \\ Criteria: A1, A3 \\ Area: 2,538 ha \\ Central coordinates: $21^{\circ} 42^{\prime} 46.55^{\prime \prime} \mathrm{E}, 41^{\circ} 46^{\prime} 37.19^{\prime \prime} \mathrm{N}$ \\ Altitude: $170-675 \mathrm{~m}$ a.s.l. \\ Administrative region(s): Veles
}

\section{Site description}

The site occupies a short section of the Vardar River Valley (southernmost parts of the entire Taor Gorge) north of Veles in central Macedonia and within its borders includes the hills that are close to the Valley, as well as the locality Kalište to the north and the locality Sredno Brdo to the south (Figure 29).

The geological composition is very diverse, belonging to the complex Vardar tectonic zone, with carbonates, metamorphic and magmatic rocks from different periods. 
Table 44: List of triggering and other important bird species in the IBA Taor Gorge

Tabela 44: Seznam kvalifikacijskih in drugih pomembnih vrst v IBA Soteska Taor

\begin{tabular}{|c|c|c|c|c|c|}
\hline $\begin{array}{l}\text { Species/ } \\
\text { Vrsta }\end{array}$ & $\begin{array}{l}\text { Season/ } \\
\text { Sezona }\end{array}$ & $\begin{array}{l}\text { Year/ } \\
\text { Leto }\end{array}$ & $\begin{array}{c}\text { Population/ } \\
\text { Populacija }\end{array}$ & $\begin{array}{l}\text { Acc./ } \\
\text { Zan. }\end{array}$ & $\begin{array}{l}\text { Criteria/ } \\
\text { Kriteriji }\end{array}$ \\
\hline Neophron percnopterus & B & 2007-2010 & I-2 & A & A1 \\
\hline Alectoris graeca & $\mathbf{R}$ & 2009 & $10-20$ & C & A3 \\
\hline Oenanthe hispanica & B & & Common & & A3 \\
\hline Sylvia cantillans & B & & Common & & A3 \\
\hline Sitta neumayer & $\mathbf{R}$ & & Common & & A3 \\
\hline Lanius nubicus & B & & Frequent & & A3 \\
\hline Emberiza melanocephala & B & & Common & & A3 \\
\hline Ciconia nigra & B & 2008 & $\mathrm{O}-\mathrm{I}$ & B & \\
\hline Circaetus gallicus & B & 2008 & $\mathrm{I}-2$ & B & $\mathrm{N}$ \\
\hline Buteo rufinus & $\mathrm{R}$ & 2009 & 2 & A & $\mathrm{N}$ \\
\hline Aquila heliaca & $\mathrm{R}$ & 2009 & O-I & B & \\
\hline Aquila chrysaetos & $\mathrm{R}$ & 2010 & O-I & B & \\
\hline Falco peregrinus & $\mathrm{R}$ & 2009 & $\mathrm{I}-2$ & B & $\mathrm{N}$ \\
\hline Bubo bubo & $\mathrm{R}$ & 2008 & $2-3$ & B & $\mathrm{N}$ \\
\hline Coracias garrulus & B & 2009 & $2-5$ & $\mathrm{C}$ & $\mathrm{N}$ \\
\hline
\end{tabular}

Table 45: The main CORINE land cover types (Level 3) in the IBA Taor Gorge

Tabela 45: Glavni tipi pokrovnosti in rabe tal (po CORINE land cover, 3. nivo) v IBA Soteska Taor

\begin{tabular}{llc}
\hline $\begin{array}{l}\text { Code/ } \\
\text { Koda }\end{array}$ & $\begin{array}{l}\text { CORINE land cover type/ } \\
\text { tip pokrovnosti in rabe tal }\end{array}$ & $\begin{array}{c}\text { Coverage/ } \\
\text { Pokrovnost (\%) }\end{array}$ \\
\hline 242 & $\begin{array}{l}\text { Complex cultivation patterns } \\
243\end{array}$ & 4.6 \\
& $\begin{array}{l}\text { Land principally occupied by } \\
\text { agriculture, with significant }\end{array}$ & 7.1 \\
& areas of natural vegetation & \\
$23 \mathrm{I}$ & Pastures & $2 \mathrm{I} \cdot 7$ \\
$3 \mathrm{II}$ & Broad-leaved forest & I8.0 \\
333 & Sparsely vegetated areas & 2.8 \\
324 & Transitional woodland-shrub & 43.5 \\
& Other & 2.4 \\
\hline
\end{tabular}

\section{Species}

The Egyptian Vulture (1-2 pairs) and a group of six species characteristic of the Mediterranean biome with significant populations meet the criteria for designation of the site as an IBA. One of the two pairs of Egyptian Vultures has not been observed since 2008 and might have been lost recently. Other important species include Eagle Owl (2-3 pairs), Long-legged Buzzard (2 pairs), Peregrine Falcon (1-2 pairs), Golden Eagle (1 pair), Black Stork (possibly one pair), and possible breeding of Imperial Eagle. A few pairs of Rollers have also been recorded (Table 44).

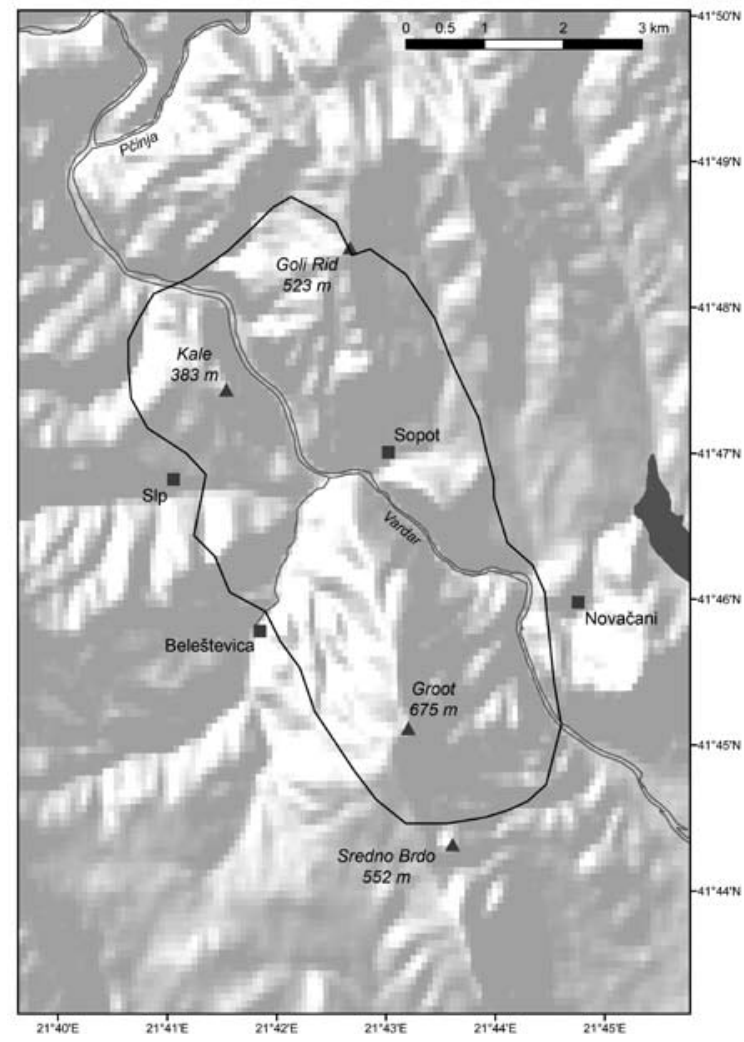

Figure 29: Map of the IBA Taor Gorge with its main features depicted

Slika 29: Zemljevid IBA Soteska Taor z glavnimi značilnostmi območja 
M. Velevski, B. Hallmann, B. Grubač, T. Lisičanec, E. Stoynov, E. Lisičanec, V. Avukatov, L. Božič \& B. Stumberger: Important Bird Areas in Macedonia: Sites of Global and European Importance

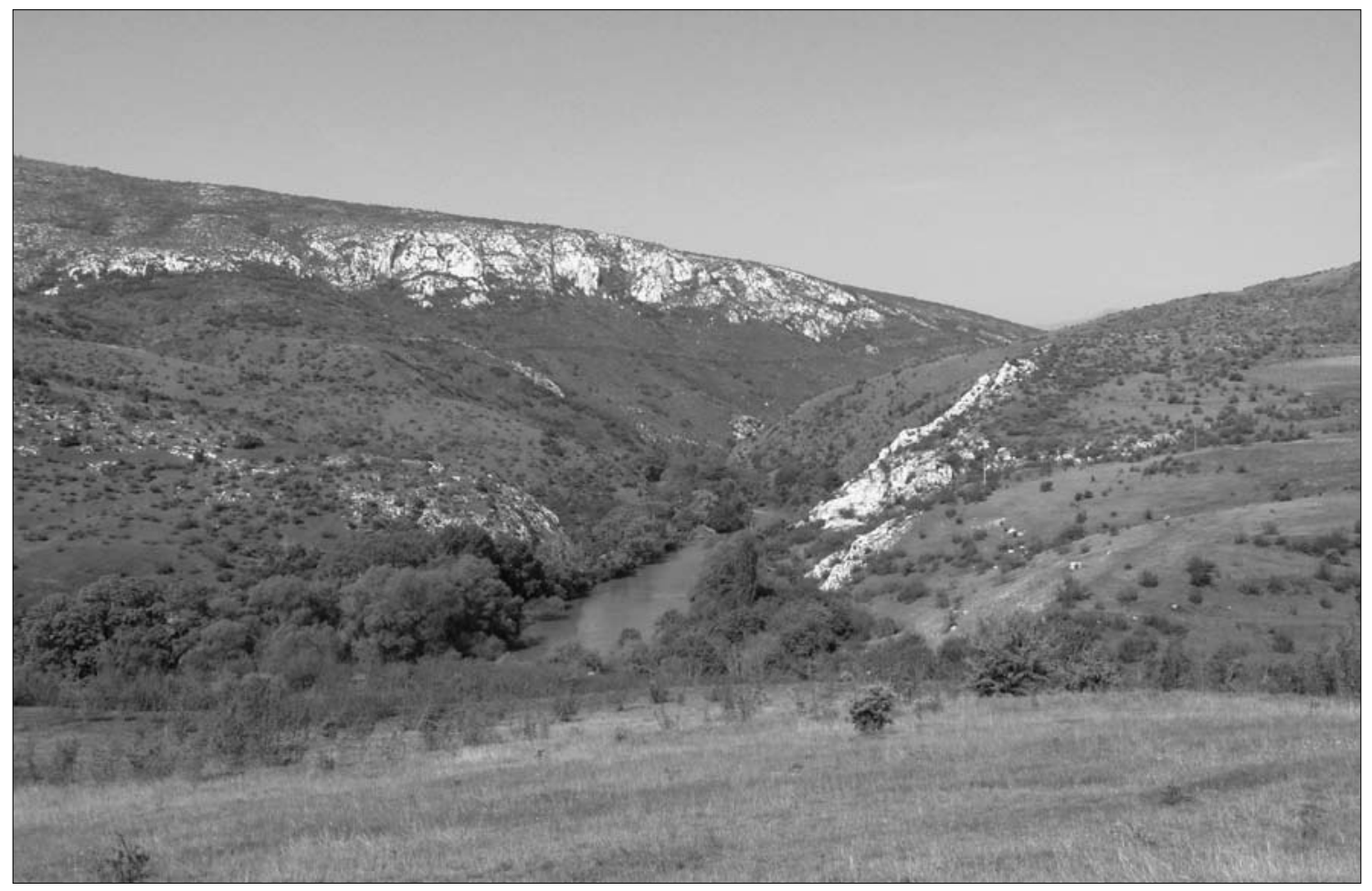

Figure 30: Characteristic landscape of the IBA Taor Gorge (photo: M. Velevski)

Slika 30: Značilna krajina IBA Soteska Taor (foto: M. Velevski)

Table 46: The main threats to birds and their importance in the IBA Taor Gorge

Tabela 46: Najpomembnejši dejavniki ogrožanja ptic in njihov vpliv v IBA Soteska Taor

\begin{tabular}{|c|c|c|c|}
\hline $\begin{array}{l}\text { Code/ } \\
\text { Koda }\end{array}$ & $\begin{array}{c}\text { Threat/ } \\
\text { Dejavnik ogrožanja }\end{array}$ & $\begin{array}{l}\text { Threat impact/ } \\
\text { Vpliv }\end{array}$ & $\begin{array}{l}\text { Most affected species/ } \\
\text { Najbolj prizadete vrste }\end{array}$ \\
\hline 960 & Interspecific faunal relations & high & A. chrysaetos, B. bubo, A. heliaca \\
\hline $4 \mathrm{IO}$ & Industrial or commercial areas & high & N. percnopterus, C. nigra, B. rufinus, C. garrulus \\
\hline 502 & Motorways, roads & high & N. percnopterus \\
\hline 162 & Artificial planting & medium & B. rufinus \\
\hline 230 & Hunting & medium & A. graeca \\
\hline 301 & Quarries & medium & B. rufinus, F. peregrinus \\
\hline 501 & Paths, tracks, cycling tracks & medium & C. nigra \\
\hline 503 & Railway lines, TGV & medium & N. percnopterus, C. nigra, B. rufinus \\
\hline 530 & Improved access to site & medium & N. percnopterus, C. nigra, B. rufinus \\
\hline 701 & Water pollution & medium & C. nigra \\
\hline 220 & Leisure fishing & medium & C. nigra \\
\hline
\end{tabular}

\section{Habitats and land use}

The most important habitats for birds are the two limestone cliffs, surrounded by pastures, remains of oak forests and scrubland, and divided by the Vardar River and its riparian willow belt (Table 45, Figure 30).

\section{Threats}

Stone mining activities are taking place in the site's close surrounding, and expansion of these activities into the site is possible. Construction of a hydro-power plant is planned, with reservoir that will submerge parts of the habitats. Construction will require translocation 
of the existing railway closer to the cliffs. The existing highway and its maintenance cause much disturbance. Afforestation with allochthonous tree species is taking place (Table 46).

\section{Conservation}

Establishment of a protected area is planned. The site partially overlaps the "Katlanovo -Taor" Emerald Site (MK0000030).

\subsubsection{Ovče Pole}

\section{General information}

Name in English: Ovče Pole

Name in Macedonian: Ovče Pole (Овче Поле)

IBA code: $\mathrm{MK} 019$

Criteria: A1, B2

Area: 48,183 ha

Central coordinates: $22^{\circ} 00^{\prime} 1.33^{\prime \prime} \mathrm{E}, 41^{\circ} 49^{\prime} 1.47^{\prime \prime} \mathrm{N}$

Altitude: $230-707 \mathrm{~m}$ a.s.l.

Administrative region(s): Veles, Lozovo, Sveti Nikole, Probištip, Karbinci, Štip, Gradsko

\section{Site description}

This large plain is situated in central Macedonia, with the site boundary starting near the town of Veles, going more or less eastwards towards the village of Kišino, then NE by following the ridges of small hills and ravines, till it reaches the village Bogoslovec. Then it continues SE to the village of Dobrošani, where it continues east to Suševo, north to Sarčievo, NE to Gorni Balvan, and again north to Pišica. From here it shares its boundary with the Zletovska River Valley site (MK012), going NW along the ridge of Mangovica Mt to the dirt road under the peak of Struga (758 $\mathrm{m}$ a.s.l.) at the village of Dolno Barbarevo. From here it shares its boundary with the Preod - Gjugjance site (MK015) SW of Nemanjica village. Then it continues south to the irrigation channel, follows it westwards to the town of Sveti Nikole, avoiding it from the south and proceeding SW to the villages of Gjuzemelci, Sojaklari and Otovica. From here it continues southwards, following the E-75 highway (Veles-Skopje), until reaching its starting point east of Veles (Figure 31).

The site is a tectonic valley, limited by Mt Mangovica, Bogoslovec Hill and the Vardar River. Geologically, it consists mostly of Pliocene lake sediments.

\section{Species}

No complete checklist of the birds of this area exists. Historically, the site was an important breeding place for the Black Vulture Aegypius monachus (Karaman 1929) and Little Bustard Tetrax tetrax (Stresemann I920). The former has not been recorded in the wider region since 1960s (Dimovski I97IA), while the last record of four Little Bustard individuals originates from the place Domus Bunar near the village of Crnilište in 1972 (TRPKOv et al. 1978).

The most important breeding species are the Imperial Eagle (10-12 pairs), Lesser Kestrel (200250 pairs), and Roller (10-30 pairs). The Imperial Eagles breed in trees and on electricity pylons often close to human settlements. Lesser Kestrels are found breeding exclusively in the villages, aggregating in large numbers (flocks of 300 ind. were seen on 13 Sep 2006, M. Velevski unpubl.) prior to their migration. The region is frequently used by foraging Griffon and Egyptian Vultures, the former arriving from the colonies at Mariovo, Tikveš Lake and Demir Kapija,

Table 47: List of triggering and other important bird species in the IBA Ovče Pole

Tabela 47: Seznam kvalifikacijskih in drugih pomembnih vrst ptic v IBA Ovče Pole

\begin{tabular}{|c|c|c|c|c|c|}
\hline $\begin{array}{l}\text { Species/ } \\
\text { Vrsta }\end{array}$ & $\begin{array}{l}\text { Season/ } \\
\text { Sezona }\end{array}$ & $\begin{array}{l}\text { Year/ } \\
\text { Leto }\end{array}$ & $\begin{array}{l}\text { Population/ } \\
\text { Populacija }\end{array}$ & $\begin{array}{l}\text { Acc./ } \\
\text { Zan. }\end{array}$ & $\begin{array}{l}\text { Criteria/ } \\
\text { Kriteriji }\end{array}$ \\
\hline Aquila beliaca & $\mathbf{R}$ & 2010 & IO-I2 & A & A1, B2 \\
\hline Coracias garrulus & B & 2006 & IO-30 & $\mathrm{C}$ & A1, B2 \\
\hline Neophron percnopterus & $\mathbf{N}$ & 2009 & $6-10$ ind. & $\mathbf{A}$ & A1 \\
\hline Falco naumanni & B & 2003 & $200-250$ & $\mathbf{A}$ & B2 \\
\hline Burbinus oedicnemus & B & 2010 & $20-50$ & C & B2 \\
\hline Lanius minor & B & 2009 & $30-100$ & C & B2 \\
\hline Gyps fulvus & $\mathrm{N}$ & 2008 & $5-20$ ind. & A & $\mathrm{N}$ \\
\hline Circaetus gallicus & $\mathrm{B}$ & 2009 & $2-4$ & $\mathrm{C}$ & $\mathrm{N}$ \\
\hline Buteo rufinus & $\mathrm{R}$ & 2010 & $2-3$ & $\mathrm{~B}$ & $\mathrm{~N}$ \\
\hline Falco cherrug & $\mathrm{B}$ & 2010 & O-I & $\mathrm{C}$ & \\
\hline
\end{tabular}


M. Velevski, B. Hallmann, B. Grubač, T. Lisičanec, E. Stoynov, E. Lisičanec, V. Avukatov, L. Božič \& B. Stumberger: Important Bird Areas in Macedonia: Sites of Global and European Importance

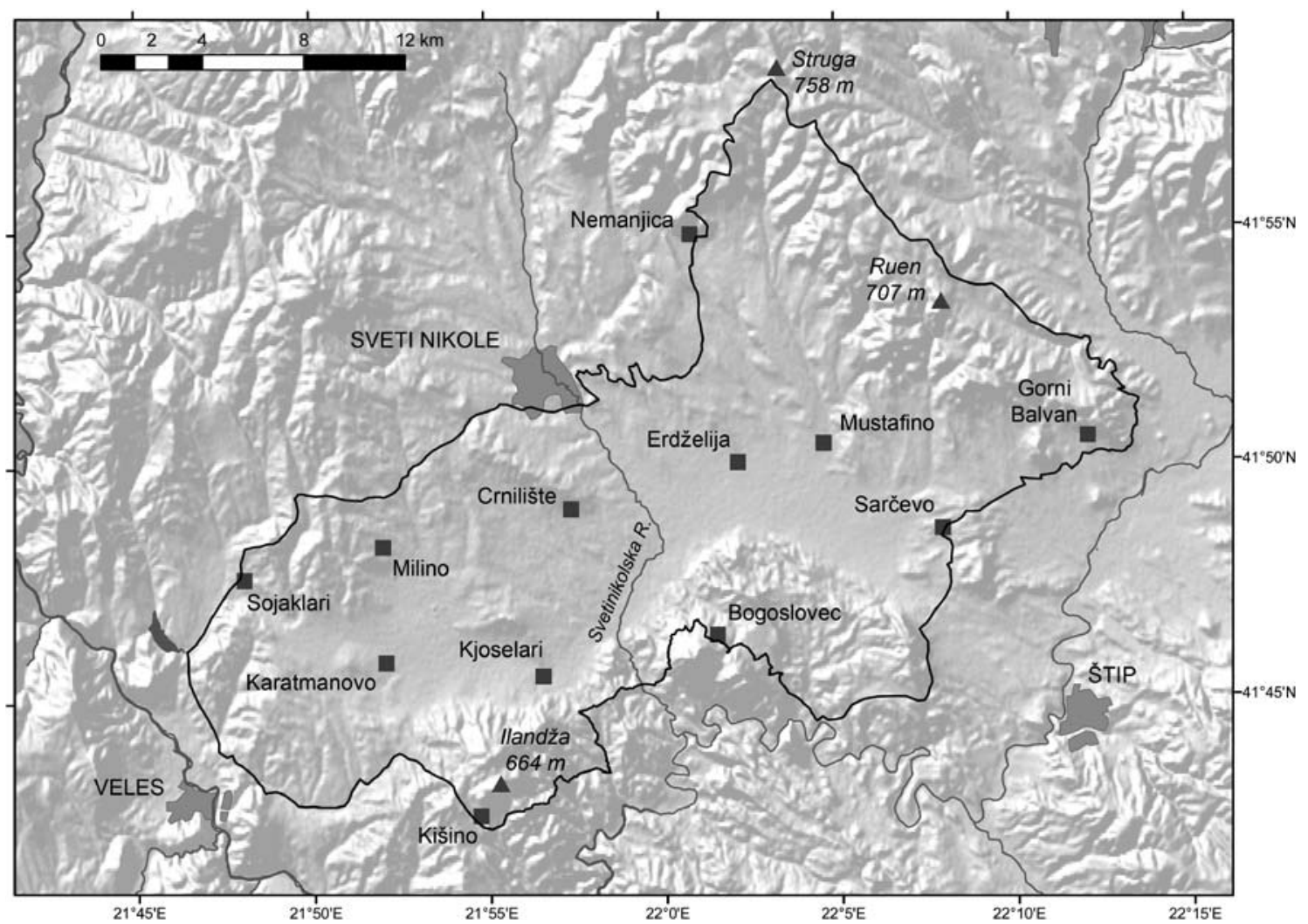

Figure 31: Map of the IBA Ovče Pole with its main features depicted

Slika 31: Zemljevod IBA Ovče Pole z glavnimi značinostmi območja

Table 48: The main CORINE land cover types (Level 3) in the IBA Ovče Pole

Tabela 48: Glavni tipi pokrovnosti in rabe tal (po CORINE land cover, 3. nivo) v IBA Ovče Pole

\begin{tabular}{llc}
\hline $\begin{array}{l}\text { Code/ } \\
\text { Koda }\end{array}$ & $\begin{array}{l}\text { CORINE land cover type/ } \\
\text { tip pokrovnosti in rabe tal }\end{array}$ & $\begin{array}{c}\text { Coverage/ } \\
\text { Pokrovnost (\%) }\end{array}$ \\
\hline 2 II & Non-irrigated arable land & 44.9 \\
242 & Complex cultivation patterns & $\mathrm{I} 5.2$ \\
243 & Land principally occupied by & 3.6 \\
& agriculture, with significant & \\
& areas of natural vegetation & \\
$23 \mathrm{I}$ & Pastures & $\mathrm{I} 5.4$ \\
$\mathrm{II2}$ & Discontinuous urban fabric & 0.4 \\
$3 \mathrm{II}$ & Broad-leaved forest & $\mathrm{I} .4$ \\
333 & Sparsely vegetated areas & 0.2 \\
324 & Transitional woodland-shrub & $\mathrm{I} 4.7$ \\
& Other & 3.9 \\
\hline
\end{tabular}

and the latter from the breeding sites at Bregalnica. Subadult individuals, however, have also been observed. Juvenile and immature Imperial Eagles are present in the wintering period as well (Table 47).

\section{Habitats and land use}

Ovče Pole is a large plain, almost entirely used for agriculture, with exception of small unsuitable salty patches and some remains of wetlands. In the peripheral parts dry pastures dominate. Tree stands with large poplar or oak trees are scattered throughout the site. Several villages are embedded in the landscape (Table 48, Figure 32).

\section{Threats}

Poisonous baits are occasionally used, resulting in poisonings of Griffon Vultures and Imperial Eagles, with the last major incident occurring in 2003 (14 Griffon Vultures and at least one Imperial Eagle found dead, T. Lisičanec, E. Lisičanec \& B. Hallman unpubl.). The plains were the most important wintering grounds for sheep in Macedonia, but their numbers have significantly decreased. Pesticide use is probably widespread due to intensive agriculture. Hunting is 


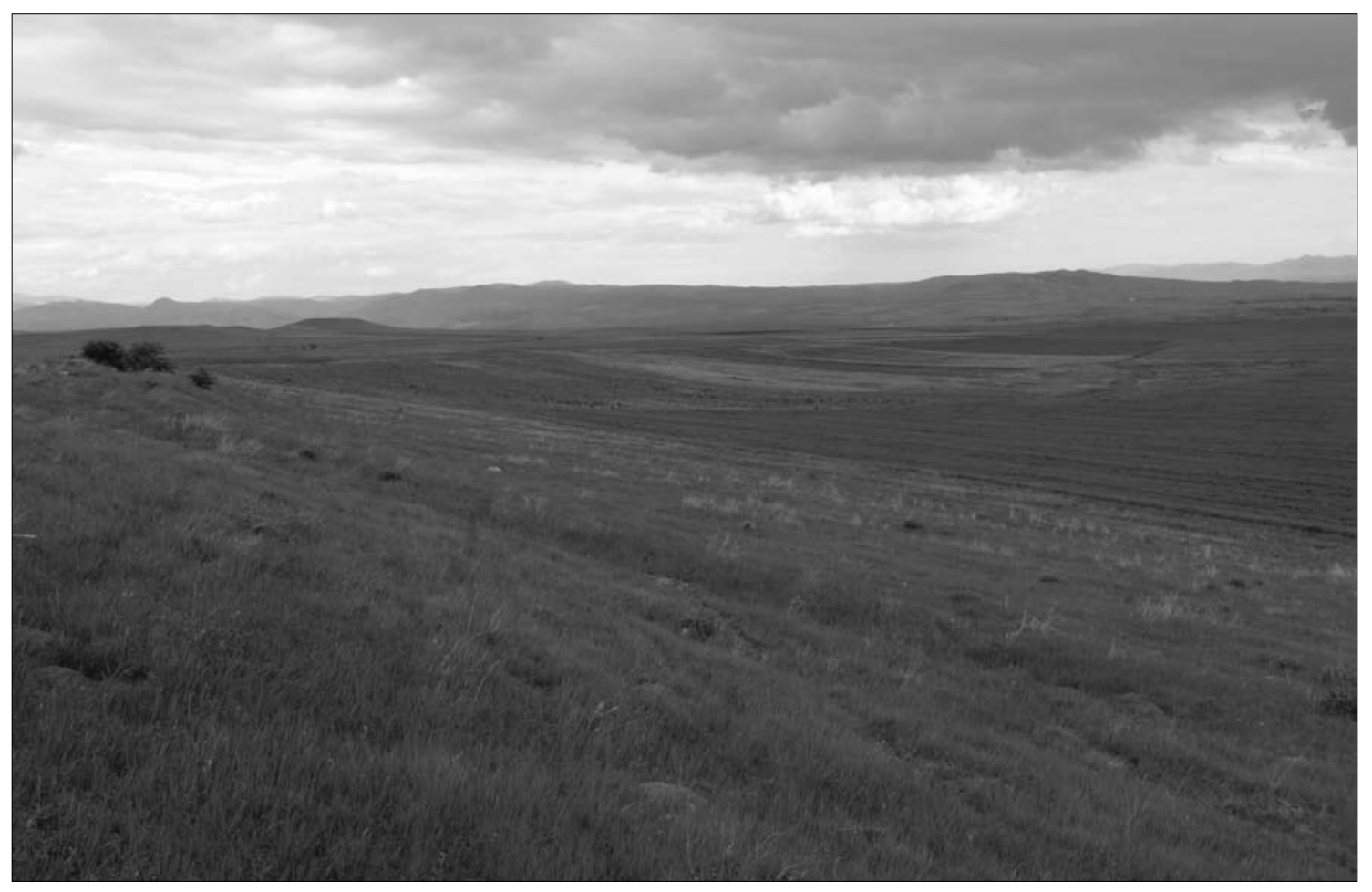

Figure 32: Characteristic landscape of the IBA Ovče Pole (photo: M. Velevski)

Slika 32: Značilna krajina v IBA Ovče Pole (foto: M. Velevski)

Table 49: The main threats to birds and their importance in the IBA Ovče Pole

Tabela 49: Najpomembnejši dejavniki ogrožanja ptic in njihov vpliv v IBA Ovče Pole

\begin{tabular}{llll}
\hline $\begin{array}{c}\text { Code/ } \\
\text { Koda }\end{array}$ & \multicolumn{1}{c}{$\begin{array}{c}\text { Threat/ } \\
\text { Dejavnik ogrožanja }\end{array}$} & $\begin{array}{c}\text { Threat impact/ } \\
\text { Vpliv }\end{array}$ & \multicolumn{1}{c}{$\begin{array}{c}\text { Most affected species/ } \\
\text { Najbolj prizadete vrste }\end{array}$} \\
\hline IIO & Use of pesticides & high & C. garrulus, F. naumanni \\
I4I & Abandonment of pastoral systems & high & G. fulvus, N. percnopterus \\
5II & Electricity lines & high & A. heliaca, F. naumanni, C. garrulus \\
243 & Trapping, poisoning, poaching & high & A. heliaca, G. fulvus \\
I6I & Forest planting & medium & B. oedicnemus \\
230 & Hunting & medium & A. heliaca \\
290 & Hunting, fishing or collecting activities & medium & A. heliaca \\
& not referred to above & & G. fulvus, N. percnopterus, A. heliaca \\
\hline 4IO & Industrial or commercial areas & medium & G.
\end{tabular}

intensive, especially of Grey Partridge Perdix perdix and Quail Coturnix coturnix, and possible risks from disturbance and secondary lead poisoning exist for the Imperial Eagles. Poaching also takes place. The threat from low and medium tension electricity poles is still unknown, but is very likely. Destruction of Imperial Eagle nests on electricity pylons, where they breed, used to take place by the State electro-distribution company. Wind farms to be erected in the future south of Štip and north of Sveti Nikole will likely impact the Imperial Eagle population and foraging vultures (Table 49).

\section{Conservation}

The site is not protected, but has been proposed as an Emerald Site (MK0000035). 
M. Velevski, B. Hallmann, B. Grubač, T. Lisičanec, E. Stoynov, E. Lisičanec, V. Avukatov, L. Božič \& B. Stumberger: Important Bird Areas in Macedonia: Sites of Global and European Importance

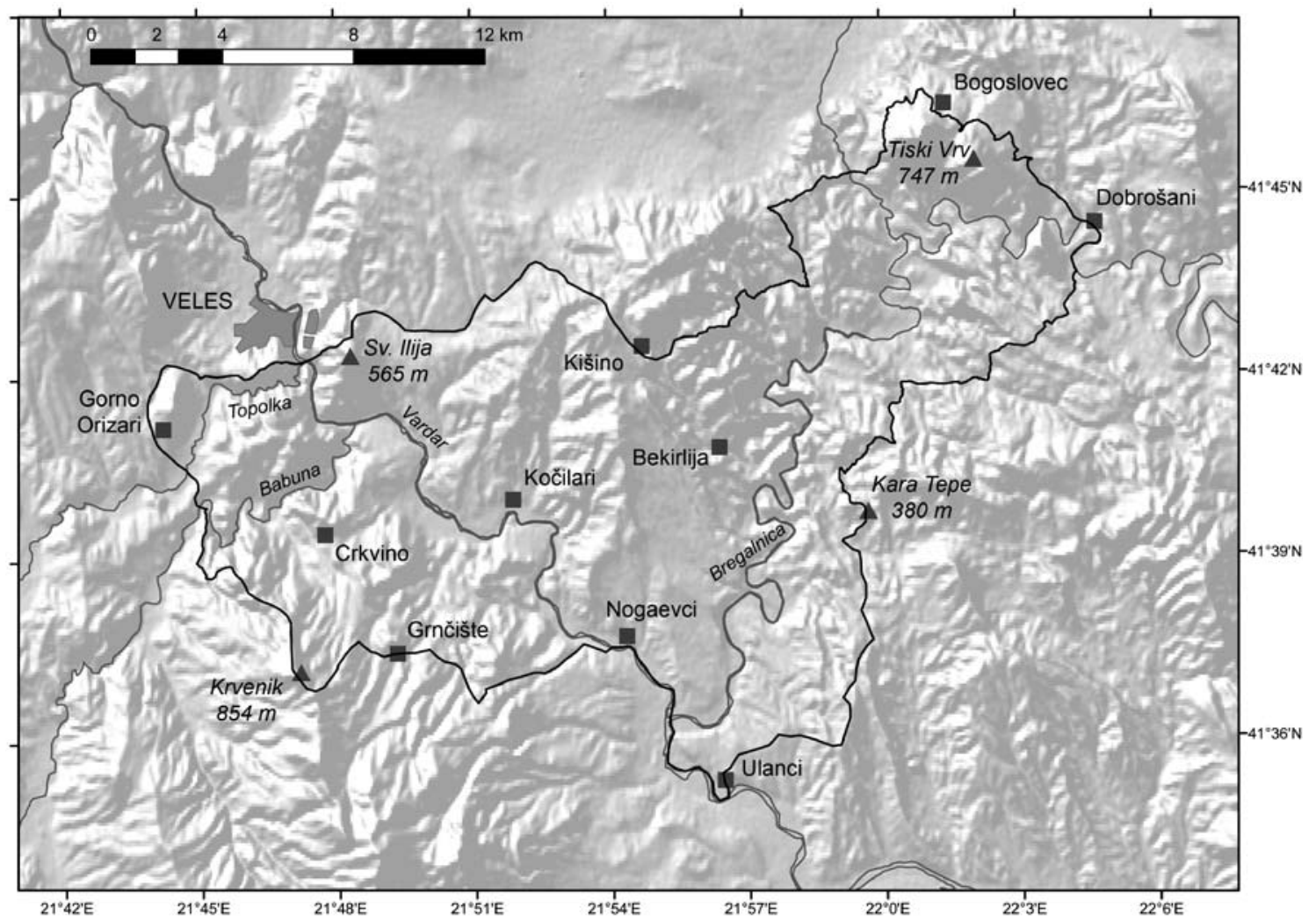

Figure 33: Map of the IBA Topolka - Babuna - Bregalnica Rivers with its main features depicted

Slika 33: Zemljevid IBA Reke Topolka - Babuna - Bregalnica z glavnimi značilnostmi območja

\subsubsection{Topolka - Babuna - Bregalnica Rivers}

\section{General information}

Name in English: Topolka - Babuna - Bregalnica Rivers Name in Macedonian: Reka Topolka - reka Babuna - reka Bregalnica (Река Тополка - река Бабуна - река Брегалница)

IBA code: $M K 020$

Criteria: A1, A3, B2

Area: 27,648 ha

Central coordinates: $21^{\circ} 54^{\prime} 27.65^{\prime \prime} \mathrm{E}, 41^{\circ} 40^{\prime} 43.23^{\prime \prime} \mathrm{N}$

Altitude: $150-755 \mathrm{~m}$ a.s.l.

Administrative region(s): Veles, Gradsko, Lozovo, Negotino, Štip, Sveti Nikole

\section{Site description}

This site unites two former IBAs in central Macedonia: the "Babuna Gorge, Topolka Gorge, and Crn Kamen" (MK003) and "Bregalnica River" (MK004) (НEATH \& Evans 2000), connecting them with the ecologically similar valley of the Vardar River in its middle section.
The boundary starts south of Veles, continues west through Prevalec settlement and turns south of the Topolka River Gorge and Bair Hill. When passing the village of Gorno Orizari, it crosses the Topolka and Babuna Rivers and continues south across the peaks of Dabović (619 m a.s.l.), Seir (677 m a.s.l.) and Krvenik (854 m. a.s.l.). From here it continues east, passing the village of Grnčište and crossing the pass under peak Cucula (469 m a.s.l.), reaching the Vardar River at the village of Nogaevci and following the river south until the village of Ulanci. From here it continues NE through Cucule, Rajnički Rid and Bunarče, then turns north to Kara Tepe. By following small ridges and ravines, it reaches the valley of the rivulet Kuri Dere, from where it continues NE till the Bregalnica River. It follows the river north to Dobrošani village, where it meets the boundary of the Ovče Pole site (MK019), following it at first NW (till Bogoslovec village), then SW to Kišino village, and west to Veles.

Dominant reliefs are the hills and gorges of the Babuna, Topolka and Bregalnica Rivers and their highly typical meanders (Figure 33). Mesozoic 
Table 50: List of triggering and other important bird species in the IBA Topolka- Babuna-Bregalnica Rivers

Tabela 50: Seznam kvalifikacijskih in drugih pomembnih vrst v IBA Reke Topolka- Babuna-Bregalnica

\begin{tabular}{|c|c|c|c|c|c|}
\hline $\begin{array}{l}\text { Species/ } \\
\text { Vrsta }\end{array}$ & $\begin{array}{l}\text { Season/ } \\
\text { Sezona }\end{array}$ & $\begin{array}{l}\text { Year/ } \\
\text { Leto }\end{array}$ & $\begin{array}{l}\text { Population/ } \\
\text { Populacija }\end{array}$ & $\begin{array}{l}\text { Acc./ } \\
\text { Zan. }\end{array}$ & $\begin{array}{l}\text { Criteria/ } \\
\text { Kriteriji }\end{array}$ \\
\hline Neophron percnopterus & B & 2010 & 4 & A & A1, B2 \\
\hline Aquila beliaca & $\mathbf{R}$ & 2010 & $3-5$ & B & A1, B2 \\
\hline Coracias garrulus & B & 2009 & $20-40$ & C & A1, B2 \\
\hline Alectoris graeca & $\mathbf{R}$ & 2010 & $30-100$ & $\mathrm{C}$ & A3, B2 \\
\hline Lanius nubicus & B & 2010 & $50-150$ & B & A3, B2 \\
\hline Oenanthe hispanica & B & & Abundant & & A3 \\
\hline Hippolais olivetorum & B & & Frequent & & A3 \\
\hline Sylvia cantillans & B & & Abundant & & A3 \\
\hline Sitta neumayer & $\mathbf{R}$ & & Frequent & & A3 \\
\hline Emberiza melanocephala & B & & Abundant & & A3 \\
\hline Circaetus gallicus & B & 2009 & $5-10$ & B & B2 \\
\hline Buteo rufinus & $\mathbf{R}$ & 2009 & $7-10$ & B & B2 \\
\hline Falco biarmicus & B & 2009 & $3-4$ & A & B2 \\
\hline Burbinus oedicnemus & B & 2009 & $20-50$ & C & B2 \\
\hline Bubo bubo & $\mathbf{R}$ & 2009 & 6-10 & C & B2 \\
\hline Monticola solitarius & B & 2003-2010 & $20-50$ & C & B2 \\
\hline Ciconia nigra & $\mathrm{B}$ & 2009 & I & A & $\mathrm{N}$ \\
\hline Gyps fulvus & $\mathrm{N}$ & 2009 & $5-20$ ind. & A & $\mathrm{N}$ \\
\hline Aquila chrysaetos & $\mathrm{R}$ & 2009 & 3 & A & $\mathrm{N}$ \\
\hline Accipiter brevipes & B & & Rare & & $\mathrm{N}$ \\
\hline Falco naumanni & B & 2002 & IO & B & $\mathrm{N}$ \\
\hline Falco peregrinus & $\mathrm{R}$ & 2009 & 3 & A & $\mathrm{N}$ \\
\hline
\end{tabular}

formations prevail in the geological composition Triassic, Jurassic and Cretaceous metamorphites, carbonates and magmatic rocks. West of the Vardar River, Eocene marine sediments are found.

\section{Species}

Parts of the site significantly differ in the level of knowledge about their bird fauna. Although the gorges of the Babuna River have been well known, attracting many ornithologists in the past (e.g. Stresemann i920, Makatsch i950, Bodenstein \& KroymanN 1967-1969), who thus provided a number of data on the nearby gorge of the Topolka River, the valley and the gorge of the Bregalnica River have been completely unknown (and hardly accessible) till recently (ŚKORPíKOVÁ et al. 2006 \& 2007), with the exception of studies of vultures in the 1980-1991 period (GRUBAČ 1997), resulting in its identification as an IBA in the first inventory (GRIMMETT \& JoNES I989).

The site holds a large number of species triggering the IBA criteria, including three species of global conservation concern and several raptor species in good
Table 51: The main CORINE land cover types (Level 3) in the IBA Topolka- Babuna-Bregalnica Rivers

Tabela 51: Glavni tipi pokrovnosti in rabe tal (po CORINE land cover, 3. nivo) v IBA Reke Topolka - Babuna - Bregalnica

\begin{tabular}{llc}
\hline $\begin{array}{l}\text { Code/ } \\
\text { Koda }\end{array}$ & $\begin{array}{l}\text { CORINE land cover type/ } \\
\text { tip pokrovnosti in rabe tal }\end{array}$ & $\begin{array}{c}\text { Coverage/ } \\
\text { Pokrovnost (\%) }\end{array}$ \\
\hline $2 \mathrm{II}$ & Non-irrigated arable land & $\mathrm{I} 2.9$ \\
242 & Complex cultivation patterns & 6.3 \\
243 & Land principally occupied by & 4.5 \\
& agriculture, with significant & \\
& areas of natural vegetation & \\
$23 \mathrm{I}$ & Pastures & 32.9 \\
333 & Sparsely vegetated areas & $\mathrm{I} .7$ \\
$32 \mathrm{I}$ & Natural grasslands & $\mathrm{I} 2.9$ \\
324 & Transitional woodland-shrub & 23.7 \\
& Other & 5.2 \\
\hline
\end{tabular}

numbers. In the past, several Griffon Vulture breeding sites were known in gorges of all three main rivers (VAsIć et al. 1985). Historically, the gorge of the Babuna River 
M. Velevski, B. Hallmann, B. Grubač, T. Lisičanec, E. Stoynov, E. Lisičanec, V. Avukatov, L. Božič \& B. Stumberger: Important Bird Areas in Macedonia: Sites of Global and European Importance

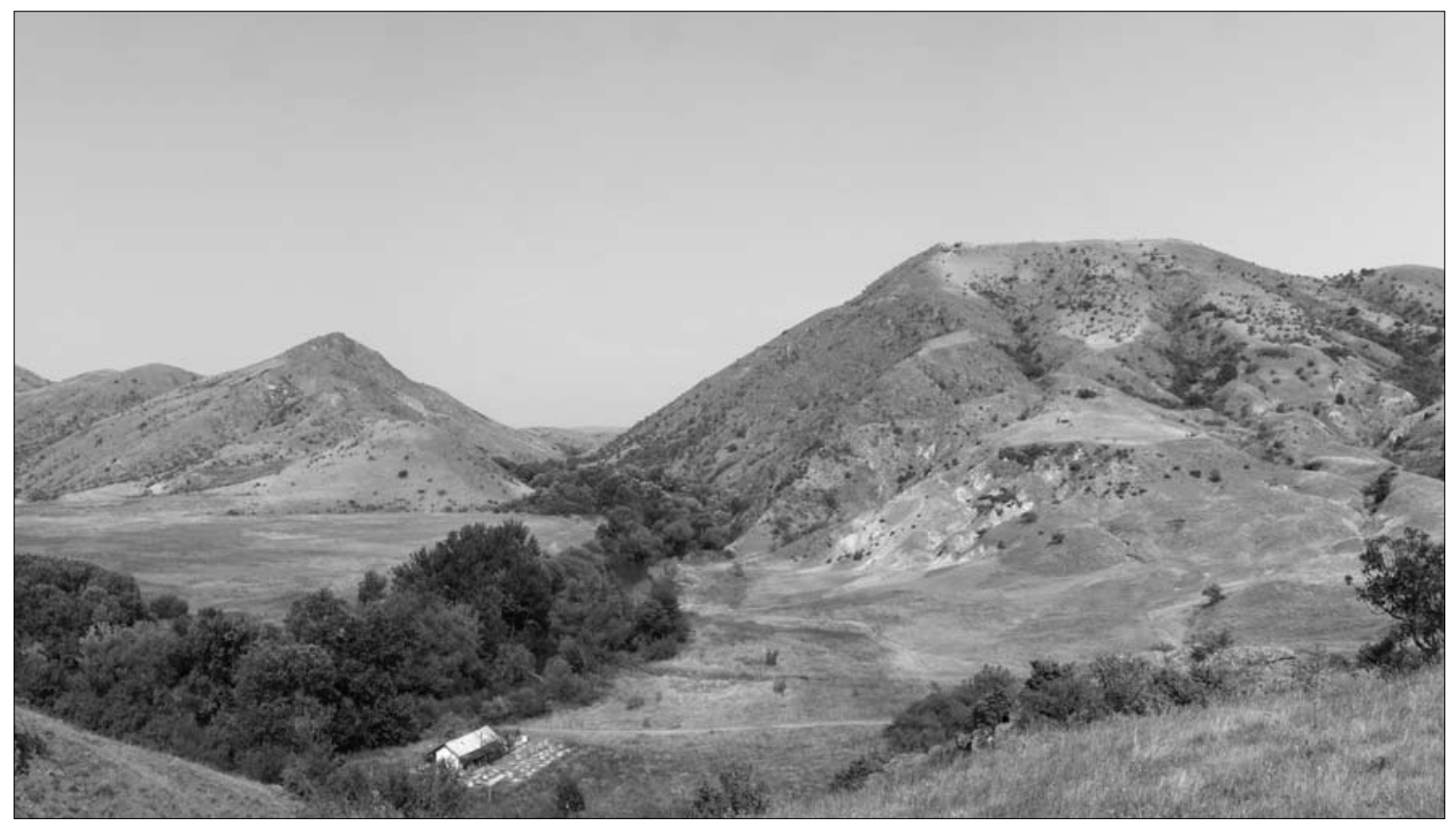

Figure 34: Characteristic landscape of the IBA Topolka - Babuna - Bregalnica Rivers (photo: M. Velevski)

Slika 34: Značina krajina IBA Reke Topolka - Babuna - Bregalnica (foto: M. Velevski)

was a breeding site of Lammergeier Gypaetus barbatus (MaKaTsCH 1950). The Mediterranean bird assemblage is characterized by the exceptionally numerous populations of Black-eared Wheatear and Blackheaded Bunting, while the Masked Shrike's population here is the largest in the country. Only one small colony (about 10 pairs) of Lesser Kestrels was found at the village of Orizari near Veles in 2002, although the species is numerous on both adjacent sites (MK019 \& MK021). Other important species include the Black
Stork, Levant Sparrowhawk and Golden Eagle (Table 50). Single historical data for Sardinian Warbler Sylvia melanocephala also exist, being the northernmost in the country (RUCNER I962-I964).

\section{Habitats and land use}

Large portion of the site is dominated by dry, steppelike pastures in different stages of succession towards oak forest, or planted with conifers. Two gorges (of the Babuna and Topolka Rivers) are found in

Table 52: The main threats to birds and their importance in the IBA Topolka - Babuna - Bregalnica Rivers

Tabela 52: Najpomembnejši dejavniki ogrožanja ptic in njihov vpliv v IBA Reke Topolka - Babuna - Bregalnica

\begin{tabular}{llll}
\hline $\begin{array}{l}\text { Code/ } \\
\text { Koda }\end{array}$ & \multicolumn{1}{c}{$\begin{array}{c}\text { Threat/ } \\
\text { Dejavnik ogrožanja }\end{array}$} & $\begin{array}{c}\text { Threat impact/ } \\
\text { Vpliv }\end{array}$ & \multicolumn{1}{c}{$\begin{array}{c}\text { Most affected species/ } \\
\text { Najbolj prizadete vrste }\end{array}$} \\
\hline I4I & Abandonment of pastoral systems & high & G. fulvus, $N$. percnopterus \\
243 & Trapping, poisoning, poaching & high & G. fulvus, $N$. percnopterus, A. heliaca \\
960 & Interspecific faunal relations & high & A. chrysaetos, B. bubo, A. heliaca \\
I00 & Cultivation & medium & B. oedicnemus, C. garrulus \\
I62 & Artificial planting & medium & B. oedicnemus \\
230 & Hunting & medium & A. graeca \\
403 & Dispersed habitation & medium & C. nigra, A. heliaca \\
624 & Mountaineering, rock climbing, speleology & medium & N. percnopterus, C. nigra \\
301 & Quarries & medium & A. graeca, M. solitarius \\
\hline
\end{tabular}


the western part, the first of which is particularly suitable for breeding of birds of prey due to large number of rock shelters and caves. The gorge of the Bregalnica River consists of sandstone, which is also full of suitable niches. Extensive agricultural fields are found especially in the surroundings of the village of Nogaevci. Riparian forest belts are dominated by Oriental Plane Platanus orientalis along the Babuna and Topolka, and poplar and willow trees along the Vardar and Bregalnica (Table 51, Figure 34).

\section{Threats}

The Topolka Gorge is threatened by the stone quarry planned to be expanded in near future, while opening of new quarries could badly impact the Babuna Gorge. Weekend cottages are becoming increasingly numerous in the Babuna Gorge; speleological and cliff-climbing activities are regular. Intensive robbery of Griffon Vulture nests has been recorded in the past (VAsić et al. 1985). The Vardar Valley and the Bregalnica River's surroundings are planted with allochthonous tree species, losing the steppe-like character. Intensive agriculture is taking place in and around the site. Along the Bregalnica, some traditional activities (capturing wild bees) cause problems to cliff-breeding raptors. Hunting, poaching and poison use still take place, resulting in direct losses (at least 10 Griffon Vultures poisoned in 2008, M. Velevski unpubl.) or prey base reduction. As elsewhere in Macedonia, livestock numbers have decreased a great deal (Table 52).

\section{Conservation}

Only a small paleontological locality (Karaslari) is under protection. Both Babuna Gorges and the Topolka Gorge have been proposed for protection. The Babuna - Topolka Gorges (MK0000023) and the Bregalnica Gorge (MK0000031) have also been proposed as Emerald Sites.

\subsubsection{Gradsko - Rosoman - Negotino}

\section{General information}

Name in English: Gradsko - Rosoman - Negotino

Name in Macedonian: Gradsko - Rosoman - Negotino (Градско - Росоман - Неготино)

IBA code: $\mathrm{MK} 021$

Criteria: A1, A3, B2

Area: 27,692 ha

Central coordinates: $21^{\circ} 58^{\prime} 40.95^{\prime \prime E}, 41^{\circ} 32^{\prime} 29.04 ” \mathrm{~N}$

Altitude: $130-898 \mathrm{~m}$ a.s.l.

Administrative region(s): Gradsko, Rosoman,

Kavadarci, Negotino

\section{Site description}

This is another site in central Macedonia that surrounds parts of the Vardar and Crna Reka Valleys. Starting from the village of Nogaevci to the west it shares the boundary with the Topolka - Babuna Bregalnica site (MK020) to the pass between the hills of Cucula and Golo Brdo (529 m a.s.l.). Then it turns

Table 53: List of triggering and other important bird species in the IBA Gradsko - Rosoman - Negotino

Tabela 53: Seznam kvalifikacijskih in drugih pomembnih vrst ptic v IBA Gradsko - Rosoman - Negotino

\begin{tabular}{|c|c|c|c|c|c|}
\hline $\begin{array}{l}\text { Species/ } \\
\text { Vrsta }\end{array}$ & $\begin{array}{l}\text { Season/ } \\
\text { Sezona }\end{array}$ & $\begin{array}{l}\text { Year/ } \\
\text { Leto }\end{array}$ & $\begin{array}{l}\text { Population/ } \\
\text { Populacija }\end{array}$ & $\begin{array}{l}\text { Acc./ } \\
\text { Zan. }\end{array}$ & $\begin{array}{l}\text { Criteria/ } \\
\text { Kriteriji }\end{array}$ \\
\hline Aquila beliaca & $\mathbf{R}$ & 2007 & $6-8$ & $\mathbf{A}$ & A1, B2 \\
\hline Coracias garrulus & B & 2007 & $20-40$ & $\mathrm{C}$ & A1, B2 \\
\hline Neophron percnopterus & $\mathbf{N}$ & 2010 & 6 ind. & B & A1 \\
\hline Alectoris graeca & $\mathbf{R}$ & & Frequent & & A3 \\
\hline Oenanthe bispanica & B & & Common & & A3 \\
\hline Hippolais olivetorum & B & & Rare & & A3 \\
\hline Lanius nubicus & B & & Rare & & A3 \\
\hline Emberiza melanocephala & B & & Common & & A3 \\
\hline Accipiter brevipes & B & 2007 & I-5 & C & B2 \\
\hline Falco naumanni & B & 2003 & $200-250$ & B & B2 \\
\hline Falco biarmicus & B & 2011 & $2-3$ & B & B2 \\
\hline Falco vespertinus & $\mathrm{P}$ & 2010 & IO-5O ind. & $\mathrm{C}$ & A1? \\
\hline Circaetus gallicus & $\mathrm{B}$ & 2007 & $3-5$ & $\mathrm{~B}$ & $\mathrm{~N}$ \\
\hline Buteo rufinus & $\mathrm{R}$ & 2007 & $2-3$ & $\mathrm{~B}$ & $\mathrm{~N}$ \\
\hline Falco peregrinus & $\mathrm{R}$ & 2006 & $\mathrm{I}-2$ & B & $\mathrm{N}$ \\
\hline
\end{tabular}


M. Velevski, B. Hallmann, B. Grubač, T. Lisičanec, E. Stoynov, E. Lisičanec, V. Avukatov, L. Božič \& B. Stumberger: Important Bird Areas in Macedonia: Sites of Global and European Importance

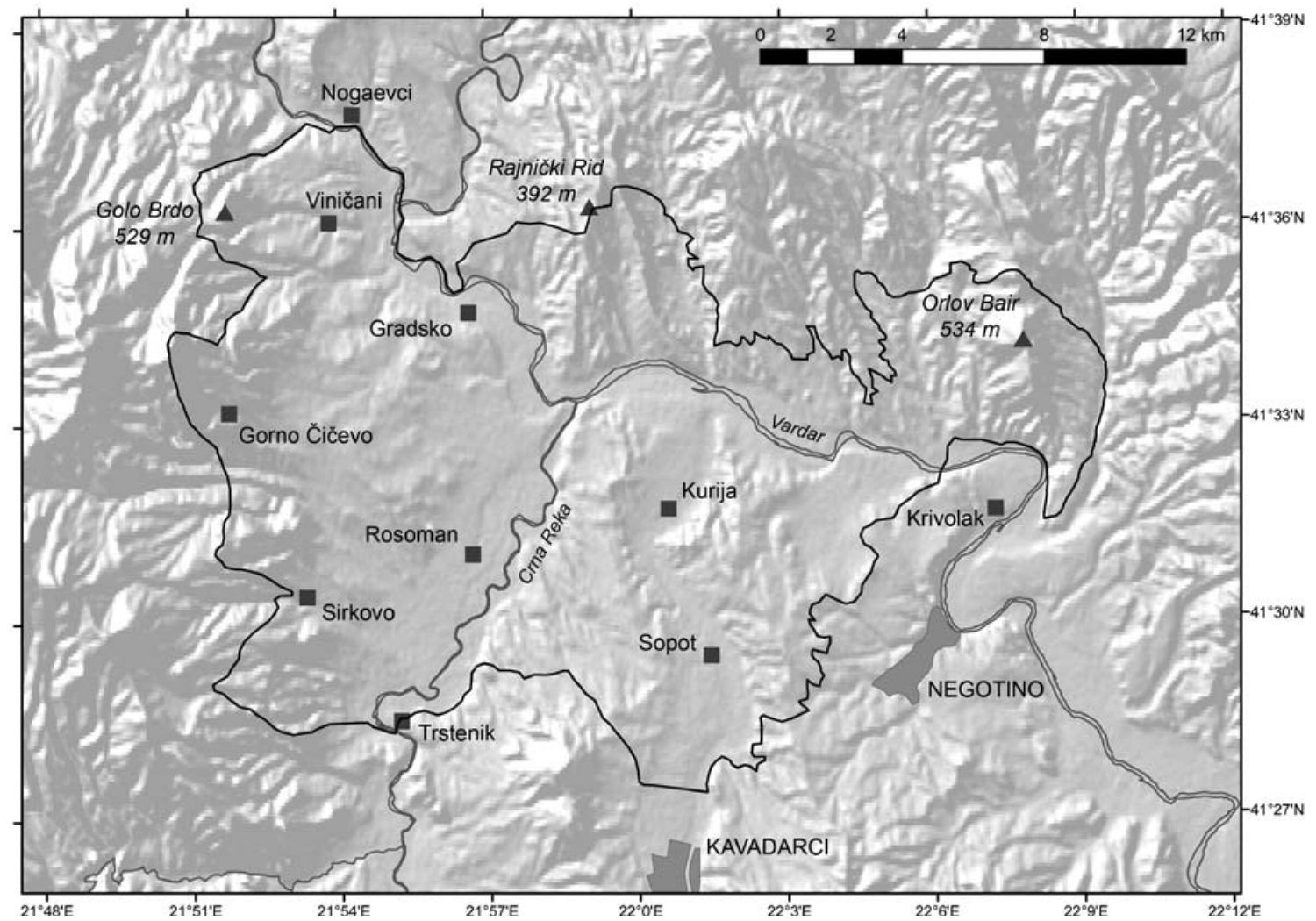

Figure 35: Map of the IBA Gradsko - Rosoman - Negotino with its main features depicted

Slika 35: Zemljevid IBA Gradsko - Rosoman - Negotino z glavnimi značilnostmi območja

south to the village of Svekjani, SE to above the village Vodovrati, and SW to above the villages of Gorno Čičevo, Sirkovo and Mrzen Oraovec. From here, the boundary turns east to Trstenik village, crosses the Crna Reka River, then following the road to this village turns SE to the village of Glišić, then turns NE, crossing the Vardar River north of Krivolak village. From here it follows the road and the left banks of the Vardar SE till north of the village of Pepelište, then turns north, passing through Štipsko Ramnište, follows the valley of the Vestinja intermittent stream to Krstata. From here it continues NW to include the peak of Jokuš (300 m a.s.l.), continues west to Kara Odžali, and passes the Slana intermittent stream. After embracing the valley of the Belkamenski Potok, it continues south to Loza and Gjubrišta. Then it turns $\mathrm{NW}$, following the $200 \mathrm{~m}$ isohypse till it meets the boundary of the Topolka - Babuna - Bregalnica Rivers site again at Rajnički Rid (392 m a.s.l.) (Figure 35).

Parts of the site belong to the Tikveš tectonic depression, intersected by the Vardar and Crna Reka Valleys. The relief is hilly, with abrasive terraces of
Table 54: The main CORINE land cover types (Level 3) in the IBA Gradsko - Rosoman - Negotino

Tabela 54: Glavni tipi pokrovnosti in rabe tal (po CORINE land cover, 3. nivo) v IBA Gradsko - Rosoman - Negotino

\begin{tabular}{llc}
\hline $\begin{array}{l}\text { Code/ } \\
\text { Koda }\end{array}$ & $\begin{array}{l}\text { CORINE land cover type/ } \\
\text { tip pokrovnosti in rabe tal }\end{array}$ & $\begin{array}{c}\text { Coverage/ } \\
\text { Pokrovnost (\%) }\end{array}$ \\
\hline 2 II & Non-irrigated arable land & 27.8 \\
242 & Complex cultivation patterns & $\mathrm{I} 4.4$ \\
243 & Land principally occupied by & 5.3 \\
& agriculture, with significant & \\
& areas of natural vegetation & \\
$23 \mathrm{I}$ & Pastures & $\mathrm{I0.3}$ \\
$22 \mathrm{I}$ & Vineyards & $\mathrm{I} 6.6$ \\
$32 \mathrm{I}$ & Natural grasslands & $\mathrm{I} 5.7$ \\
324 & Transitional woodland-shrub & 6.8 \\
& Other & 2.9 \\
\hline
\end{tabular}

fossil lake and recent fluvial terraces. Pliocene lake sediments and recent alluvial deposits are dominant. 


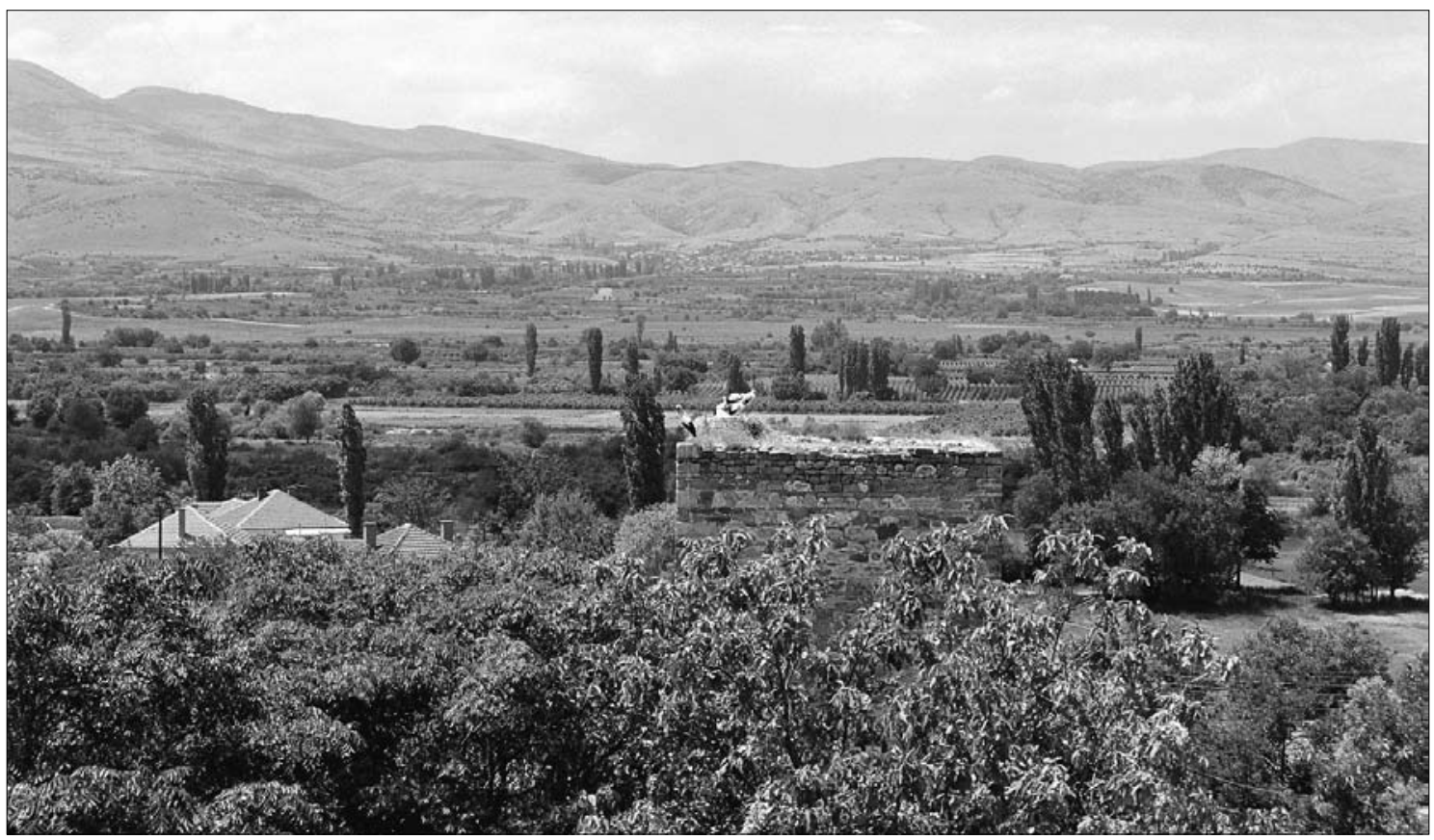

Figure 36: Characteristic landscape of the IBA Gradsko - Rosoman - Negotino (photo: E. Lisičanec)

Slika 36: Značina krajina IBA Gradsko - Rosoman - Negotino (foto: E. Lisičanec)

Table 55: The main threats to birds and their importance in the IBA Gradsko - Rosoman - Negotino

Tabela 55: Najpomembnejši dejavniki ogrožanja ptic in njihov vpliv v IBA Gradsko - Rosoman - Negotino

\begin{tabular}{llll}
\hline $\begin{array}{l}\text { Code/ } \\
\text { Koda }\end{array}$ & \multicolumn{1}{c}{$\begin{array}{c}\text { Threat/ } \\
\text { Dejavnik ogrožanja }\end{array}$} & $\begin{array}{c}\text { Threat impact/ } \\
\text { Vpliv }\end{array}$ & \multicolumn{1}{c}{$\begin{array}{c}\text { Most affected species/ } \\
\text { Najbolj prizadete vrste }\end{array}$} \\
\hline IIO & Use of pesticides & high & F. naumanni, C. garrulus \\
243 & Trapping, poisoning, poaching & high & A. heliaca, A. chrysaetos, B. rufinus \\
5II & Electricity lines & high & A. heliaca, F. naumanni, C. garrulus \\
I0O & Cultivation & medium & F. naumanni, C. garrulus \\
I6I & Forest planting & medium & F. naumanni \\
730 & Military manoeuvres & medium & A. heliaca, B. rufinus \\
\hline
\end{tabular}

\section{Species}

No comprehensive study of the bird fauna of this part of Macedonia has been carried out, although the checklist is quite complete, comprising about 130 species. Most significant species are the Imperial Eagle (6-8 pairs), breeding along the Vardar River, Lesser Kestrel (200-250 pairs), breeding in villages as well as in sand cliffs, which has been rare in the last few decades in Macedonia, Roller (20-40 pairs), Lanner Falcon (2-3 pairs), and a number of Red-footed Falcons during their spring migration. Up to six adult and subadult Egyptian Vultures have been observed in the region, foraging or gathering at predictable food sources, but no recent breeding pair is known. Five species characteristic of the Mediterranean biome regularly breed in good numbers, but with unknown population sizes. Among other important species found below the threshold numbers set, are the Longlegged Buzzard and the Short-toed Eagle (Table 53).

\section{Habitats and land use}

The site is dominated by agricultural land (mostly arable fields, but also many vineyards and some orchards), but at the periphery, dry and sometimes steppe-like 
M. Velevski, B. Hallmann, B. Grubač, T. Lisičanec, E. Stoynov, E. Lisičanec, V. Avukatov, L. Božič \& B. Stumberger: Important Bird Areas in Macedonia: Sites of Global and European Importance

pastures are present. The banks of the Vardar are overgrown with riparian vegetation, mostly consisting of poplar and willow trees (Table 54, Figure 36).

\section{Threats}

Intensive agriculture, especially vineyard plantations, still expanding in some parts of the site, have converted large portions of the site into inappropriate habitat for triggering species. Pesticide use both in vineyards and cereal crops is intensive. Some parts of the site have been afforested with allochthonous tree species. Hunting and poaching are present; direct killing of important species, like Imperial and Golden Eagles, has been documented. Along the eastern bank of the Vardar, there is most probably some disturbance present due to military manoeuvres. Mediumtension electricity poles likely cause some mortality in important species (Table 55).

\section{Conservation}

SE parts of the site (Orlovo Brdo) are protected as Nature Monuments (1,981 ha) due to their botanical values. There are no conservation plans for the rest of the territory, nor do any particular bird conservation measures exist.

\subsubsection{Lake Mantovo and Kriva Lakavica River}

\section{General information}

Name in English: Lake Mantovo and Kriva Lakavica River

Name in Macedonian: Ezero Mantovo i reka Kriva

Lakavica (Езеро Мантово и река Крива Лакавица)

IBA code: $\mathrm{MK} 022$

Criteria: A1, B2

Area: 6,920 ha

Central coordinates: $22^{\circ} 18^{\prime} 35.69^{\prime \prime} \mathrm{E}, 41^{\circ} 35^{\prime} 41.38^{\prime \prime} \mathrm{N}$

Altitude: $350-697 \mathrm{~m}$ a.s.l.

Administrative region(s): Štip, Konče, Radoviš

Table 56: List of triggering and other important bird species in the IBA Lake Mantovo and Kriva Lakavica River

Tabela 56: Seznam kvalifikacijskih in drugih pomembnih vrst v IBA Jezero Mantovo in reka Kriva Lakavica

\begin{tabular}{lccccc}
\hline $\begin{array}{l}\text { Species/ } \\
\text { Vrsta }\end{array}$ & $\begin{array}{c}\text { Season/ } \\
\text { Sezona }\end{array}$ & $\begin{array}{c}\text { Year/ } \\
\text { Leto }\end{array}$ & $\begin{array}{c}\text { Population/ } \\
\text { Populacija }\end{array}$ & $\begin{array}{c}\text { Acc./ } \\
\text { Zan. }\end{array}$ & $\begin{array}{c}\text { Criteria/ } \\
\text { Kriteriji }\end{array}$ \\
\hline Coracias garrulus & $\mathbf{B}$ & $\mathbf{2 0 0 7}$ & $\mathbf{5 - 1 5}$ & $\mathbf{C}$ & $\mathbf{A 1}$ \\
Lanius nubicus & $\mathbf{B}$ & $\mathbf{2 0 0 7}$ & $\mathbf{1 0 - 3 0}$ & $\mathbf{C}$ & $\mathbf{B 2}$ \\
Ciconia nigra & $\mathrm{B}$ & 2008 & $\mathrm{I}$ & $\mathrm{B}$ & $\mathrm{N}$ \\
Aquila chrysaetos & $\mathrm{R}$ & 2005 & $\mathrm{I}$ & $\mathrm{A}$ & $\mathrm{N}$ \\
Falco biarmicus & $\mathrm{B}$ & 2008 & $\mathrm{I}$ & $\mathrm{A}$ & $\mathrm{N}$ \\
Bubo bubo & $\mathrm{R}$ & 2008 & $2-3$ & $\mathrm{C}$ & $\mathrm{N}$ \\
\hline
\end{tabular}




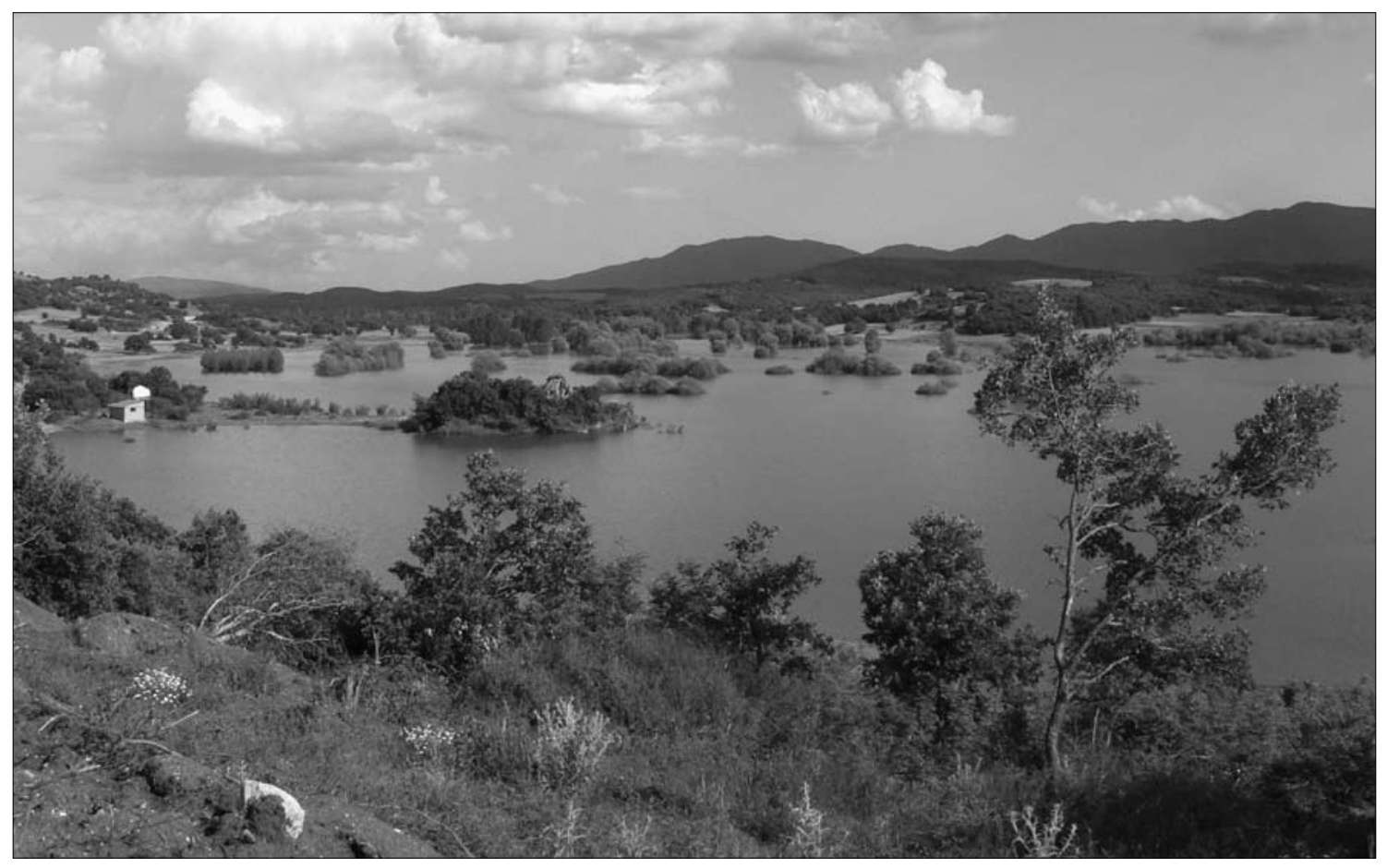

Figure 38: Characteristic landscape of the IBA Lake Mantovo and Kriva Lakavica River (photo: M. Velevski)

Slika 38: Značilna krajina v IBA Jezero Mantovo in reka Kriva Lakavica (foto: M. Velevski)

m. It follows it till east of Leskovica village, where it ascends to $500 \mathrm{~m}$, following it until east of Garvan village. From here it continues south to the village of Zagorci, east to the village of Skoruša and the Radeški

Table 57: The main CORINE land cover types (Level 3) in the IBA Lake Mantovo and the Kriva Lakavica River

Tabela 57: Glavni tipi pokrovnosti in rabe tal (po CORINE land cover, 3. nivo) v IBA Jezero Mantovo in reka Kriva Lakavica

\begin{tabular}{llc}
\hline $\begin{array}{l}\text { Code/ } \\
\text { Koda }\end{array}$ & $\begin{array}{l}\text { CORINE land cover type/ } \\
\text { tip pokrovnosti in rabe tal }\end{array}$ & $\begin{array}{c}\text { Coverage/ } \\
\text { Pokrovnost (\%) }\end{array}$ \\
\hline 2 II & Non-irrigated arable land & 9.8 \\
242 & Complex cultivation patterns & I8.5 \\
243 & Land principally occupied by & I0.2 \\
& agriculture, with significant & \\
& areas of natural vegetation & \\
23I & Pastures & 7.7 \\
3II & Broad-leaved forest & II.4 \\
324 & Transitional woodland-shrub & 36.0 \\
5I2 & Water bodies & 3.4 \\
& Other & 3.4 \\
\hline
\end{tabular}

Rid locality, and by following the Radeška Reka rivulet reaches the eastern shore of Lake Mantovo. Then it runs along the lake shore until reaching the Golinite ridge, and continues north to Golema Niva and Samardžica. Here it ascends NW to Golema Čuka (675 m a.s.l.) and then descends east of Pilav Tepe (Figure 37).

The site is comprised of the Kriva Lakavica River. In the northern parts dominant are volcanogenic rocks with paleovolcanic relief (volcanic cones) are dominant, while in the southern parts Paleozoic metamorphic rocks prevail.

\section{Species}

The only triggering species for the site are the Roller (5-15 pairs) and the Masked Shrike (10-30 pairs), although several other important species breed in low numbers there: Lanner Falcon, Black Stork, Golden Eagle, Eagle Owl, and possibly Egyptian Vulture (Š́KORPíKOVÁ et al. 2006). The importance of the lake for waterbirds is unknown, although it is possibly high during migration (Table 56).

\section{Habitats and land use}

The artificial reservoir blends with the landscape, which is composed of volcanic stones and cliffs, 
M. Velevski, B. Hallmann, B. Grubač, T. Lisičanec, E. Stoynov, E. Lisičanec, V. Avukatov, L. Božič \& B. Stumberger: Important Bird Areas in Macedonia: Sites of Global and European Importance

Table 58: The main threats to birds and their importance in the IBA Lake Mantovo and Kriva Lakavica River

Table 58: Najpomembnejši dejavniki ogrožanja ptic in njihov vpliv v IBA Jezero Mantovo in reka Kriva Lakavica

\begin{tabular}{llll}
\hline $\begin{array}{l}\text { Code/ } \\
\text { Koda }\end{array}$ & \multicolumn{1}{c}{$\begin{array}{c}\text { Threat/ } \\
\text { Dejavnik ogrožanja }\end{array}$} & $\begin{array}{c}\text { Threat impact/ } \\
\text { Vpliv }\end{array}$ & $\begin{array}{c}\text { Most affected species/ } \\
\text { Najbolj prizadete vrste }\end{array}$ \\
\hline 242 & Taking from nest (falcons) & medium & F. biarmicus \\
243 & Trapping, poisoning, poaching & medium & F. biarmicus \\
$33 \mathrm{I}$ & Open cast mining & medium & L. nubicus \\
$70 \mathrm{I}$ & Water pollution & medium & C. nigra \\
\hline
\end{tabular}

overgrown with oak scrubland and forms forest stands in places. Part of the site is used for agriculture. The Kriva Lakavica River Valley is densely overgrown with mostly Willow, but also Poplar trees that form wellpreserved riparian belts (Table 57, Figure 38).

\section{Threats}

Highest threat comes from the possible expansion of "Damjan" and "Bučim" surface copper mines. Both mines severely pollute the Medenska Reka River, a tributary to the Kriva Lakavica. Nest robbery has been noted. Hunting and poaching probably take place (Table 58).

\section{Conservation}

No specific conservation activities have been planned.

\subsubsection{Raec River Valley}

\section{General information}

Name in English: Raec River Valley

Name in Macedonian: Dolina na reka Raec (Долина на река Раец)

IBA code: $\mathrm{MK} 023$

Criteria: A1, A3, B2

Area: 19,805 ha

Central coordinates: $21^{\circ} 47^{\prime} 41.52^{\prime \prime} \mathrm{E}, 41^{\circ} 23^{\prime} 43.90^{\prime \prime} \mathrm{N}$

Altitude: $170-1,745 \mathrm{~m}$ a.s.l.

Administrative region(s): Kavadarci, Prilep, Rosoman

\section{Site description}

The site is situated west of Kavadarci town in southern-central Macedonia. Starting from the village

Table 59: List of triggering and other important bird species in the IBA Raec River Valley

Tabela 59: Seznam kvalifikacijskih in drugih pomembnih vrst ptic v IBA Dolina reke Raec

\begin{tabular}{|c|c|c|c|c|c|}
\hline $\begin{array}{l}\text { Species/ } \\
\text { Vrsta }\end{array}$ & $\begin{array}{l}\text { Season/ } \\
\text { Sezona }\end{array}$ & $\begin{array}{l}\text { Year/ } \\
\text { Leto }\end{array}$ & $\begin{array}{l}\text { Population/ } \\
\text { Populacija }\end{array}$ & $\begin{array}{l}\text { Acc./ } \\
\text { Zan. }\end{array}$ & $\begin{array}{l}\text { Criteria/ } \\
\text { Kriteriji }\end{array}$ \\
\hline Neophron percnopterus & B & 2008-2010 & $2-5$ & B & A1, B2 \\
\hline Alectoris graeca & $\mathbf{R}$ & & Frequent & & A3 \\
\hline Oenanthe bispanica & B & & Common & & A3 \\
\hline Sylvia cantillans & B & & Common & & A3 \\
\hline Sitta neumayer & $\mathbf{R}$ & & Common & & A3 \\
\hline Emberiza melanocephala & B & & Common & & A3 \\
\hline Ciconia nigra & B & 2007 & $2-3$ & B & B2 \\
\hline Falco naumanni & B & 2003 & $15-25$ & B & B2 \\
\hline Milvus migrans & $\mathrm{B}$ & 2009 & $\mathrm{O}-\mathrm{I}$ & $\mathrm{B}$ & \\
\hline Circaetus gallicus & $\mathrm{B}$ & 2010 & $\mathrm{I}-2$ & $\mathrm{~B}$ & $\mathrm{~N}$ \\
\hline Accipiter brevipes & $\mathrm{B}$ & 2004 & $I-2$ & $\mathrm{C}$ & $\mathrm{N}$ \\
\hline Buteo rufinus & $\mathrm{R}$ & 2009 & $\mathrm{I}-2$ & $\mathrm{~B}$ & $\mathrm{~N}$ \\
\hline Aquila chrysaetos & $\mathrm{R}$ & 2009 & $2-3$ & $\mathrm{~B}$ & $\mathrm{~N}$ \\
\hline Falco peregrinus & $\mathrm{R}$ & 2010 & $2-3$ & $\mathrm{~B}$ & $\mathrm{~N}$ \\
\hline Bubo bubo & $\mathrm{R}$ & 2008 & $3-4$ & B & $\mathrm{N}$ \\
\hline
\end{tabular}




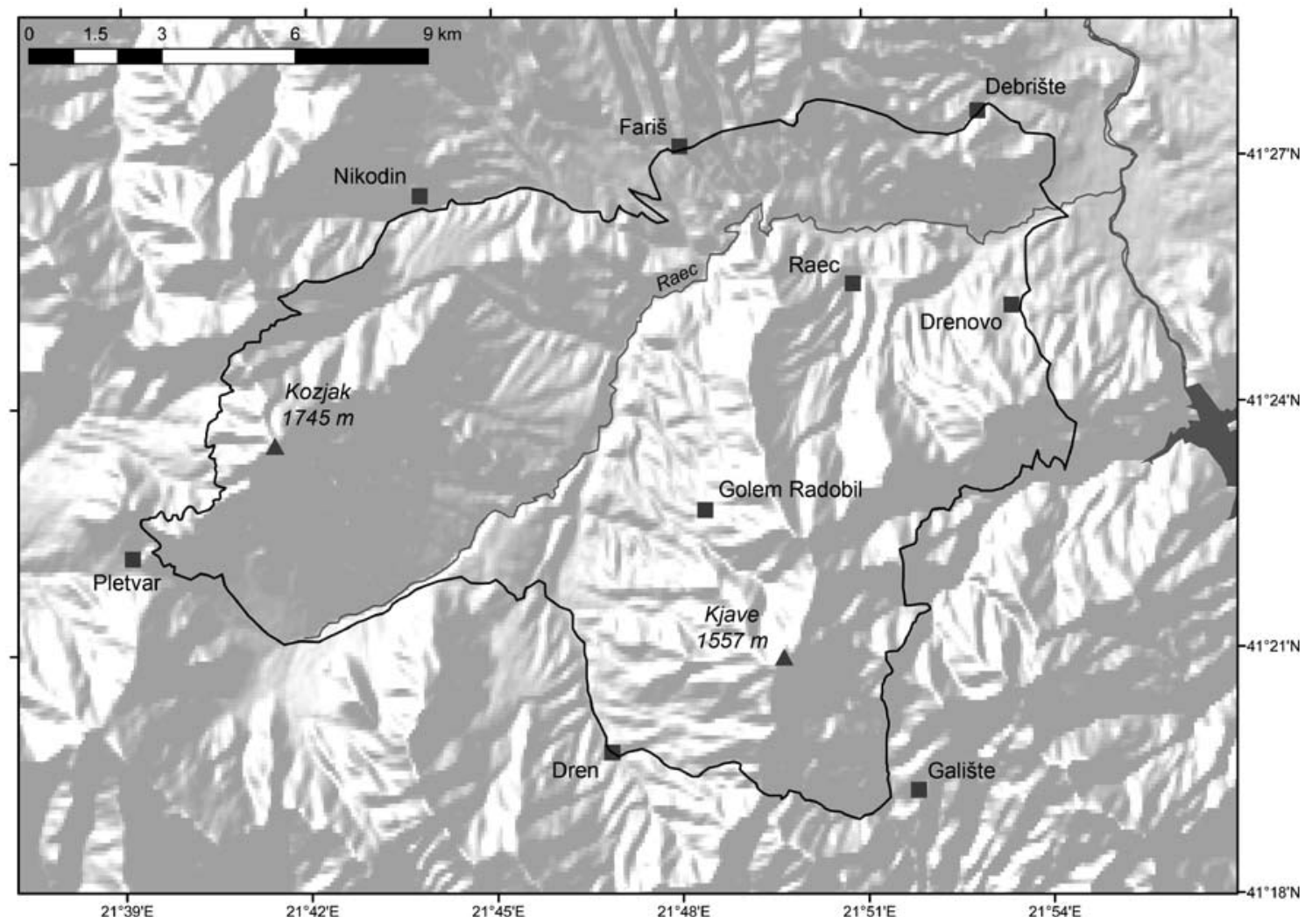

Figure 39: Map of the IBA Raec River Valley with its main features depicted

Slika 39: Zemljevid IBA Dolina reke Raec z glavnimi značilnostmi območja

of Debrešte, the boundary runs west to the villages of Faris and Nikodin, and then turns SW to the villages Krstec and Pletvar. Here, it turns east to the village

Table 60: The main CORINE land cover types (Level 3) in the IBA Raec River Valley

Tabela 60: Glavni tipi pokrovnosti in rabe tal (po CORINE land cover, 3. nivo) v IBA Dolina reke Raec

\begin{tabular}{|c|c|c|}
\hline $\begin{array}{l}\text { Code/ } \\
\text { Koda }\end{array}$ & $\begin{array}{l}\text { CORINE land cover type/ } \\
\text { tip pokrovnosti in rabe tal }\end{array}$ & $\begin{array}{c}\text { Coverage/ } \\
\text { Pokrovnost }(\%)\end{array}$ \\
\hline 242 & Complex cultivation patterns & $4 . \mathrm{I}$ \\
\hline 243 & $\begin{array}{l}\text { Land principally occupied by } \\
\text { agriculture, with significant } \\
\text { areas of natural vegetation }\end{array}$ & 5.7 \\
\hline $23 \mathrm{I}$ & Pastures & 6.3 \\
\hline $3 \mathrm{II}$ & Broad-leaved forest & $34 \cdot 9$ \\
\hline 321 & Natural grasslands & IO.4 \\
\hline \multirow[t]{2}{*}{324} & Transitional woodland-shrub & 34.0 \\
\hline & Other & 4,6 \\
\hline
\end{tabular}

of Carevik, south to Dren village and east to the village of Galište, then continues north to the villages of Grbovec, Dradnja and Drenovo, before reaching Debrešte again. Smaller part of the site (the lower gorge of the Raec River, known as Drenovo Gorge) was formerly part of the IBA "Crna River Gorge" (MK007, Heath \& Evans 2000).

North and NW of the Raec River, Mt Babuna with its peak Kozjak (1,745 m a.s.l.) is situated, while south of the river the mountain Dren is located. Geologically, Precambrian metamorphic and magmatic rocks are present in Mt Babuna and Mesozoic formations on Mt Dren. The Drenovo and Fariš Gorges are located in the eastern part of the Raec Valley (Figure 39).

\section{Species}

Some sporadic data on few species have been published for Drenovo Gorge (Kalaber i970, Danko \& Szilárd I97I), but no detailed survey exists. Besides significant populations of Egyptian Vultures that declined from 4-5 pairs in 2008 to only two pairs in 2010 (the reasons for this large decline are not known) and Lesser 


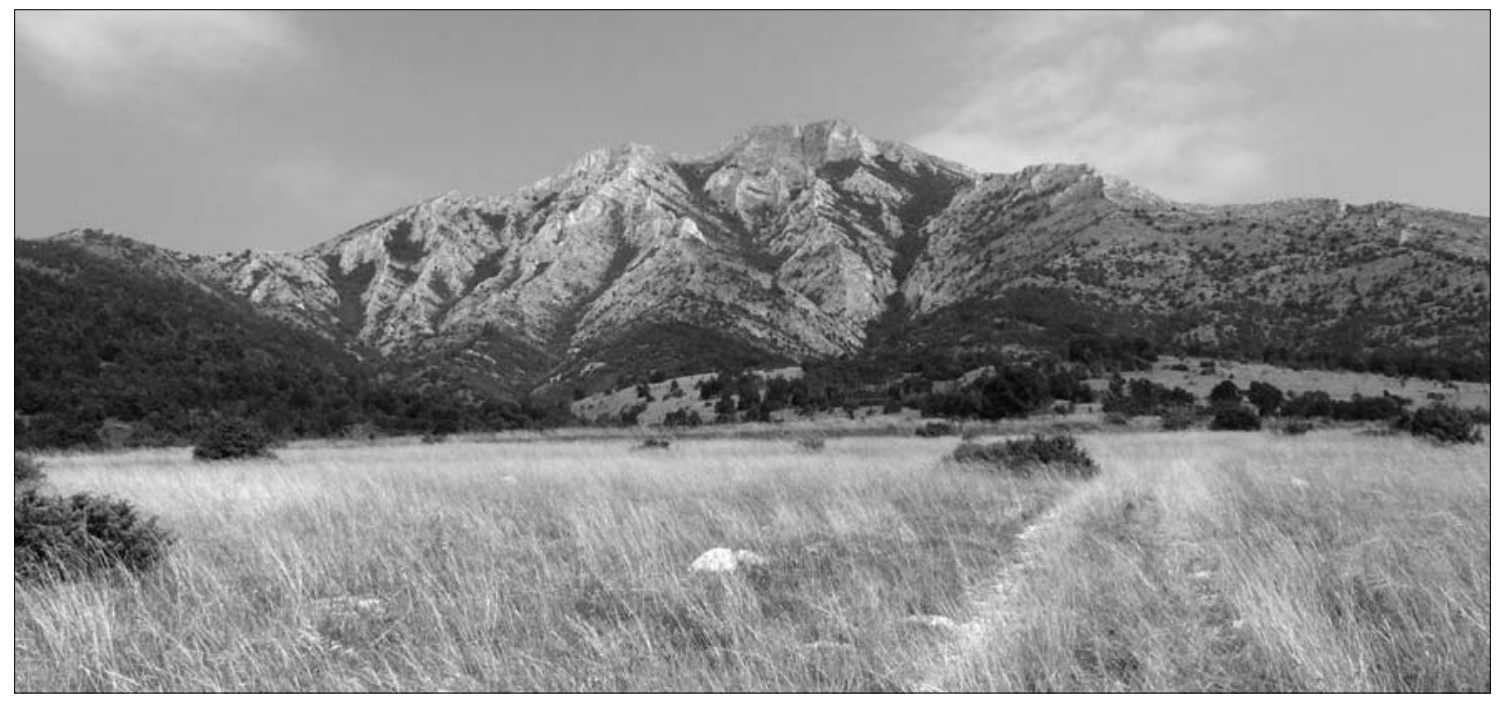

Figure 40: Characteristic landscape of the IBA Raec River Valley (photo: M. Velevski)

Slika 40: Značilna krajina IBA Dolina reke Raec (foto: M. Velevski)

Kestrels that breed mostly in villages (although a small colony was found in the cliffs as well), the site holds 3-4 pairs of Eagle Owl, 2-3 pairs of Golden Eagle, 2-3 pairs of Black Stork, at least two pairs of Peregrine Falcon, possibly one pair of Black Kite, and several species characteristic of the Mediterranean biome in good numbers (Table 59).

\section{Habitats and land use}

Oak and to a much smaller degree Beech Fagus sylvatica forests are found in the higher parts of the site, but as the altitude decreases forests are replaced by dry pastures and grasslands through different degradation stages. Two small limestone gorges are of highest importance in the site's eastern part, while one large limestone cliff and several smaller silicate cliffs are most important in the western part of the site (Table 60, Figure 40).

\section{Threats}

Private weekend-houses are being built on some key locations. Hunting and poaching probably take place. Livestock numbers have decreased, probably indirectly influencing a number of vultures in the region. Recent forest fires have probably depleted prey base for the birds of prey. Hunting and poaching have also very likely resulted in reduction of prey base, especially for Golden Eagles and Eagle Owls (Table 61).

\section{Conservation}

A small portion of the site (Drenovo Gorge, 9 ha) has been protected. Parts of the site are proposed as "Raec" Emerald Site (MK0000028).

Table 61: The main threats to birds and their importance in the IBA Raec River Valley

Tabela 61: Najpomembnejši dejavniki ogrožanja ptic in njihov vpliv v IBA Dolina reke Raec

\begin{tabular}{llll}
\hline $\begin{array}{l}\text { Code/ } \\
\text { Koda }\end{array}$ & \multicolumn{1}{c}{$\begin{array}{c}\text { Threat/ } \\
\text { Dejavnik ogrožanja }\end{array}$} & $\begin{array}{c}\text { Threat impact/ } \\
\text { Vpliv }\end{array}$ & \multicolumn{1}{c}{$\begin{array}{c}\text { Most affected species/ } \\
\text { Najbolj prizadete vrste }\end{array}$} \\
\hline 960 & Interspecific faunal relations & high & A. chrysaetos, B. bubo \\
I4I & Abandonment of pastoral systems & medium & N. percnopterus, F. naumanni \\
301 & Quarries & medium & N. percnopterus, B. bubo, B. rufinus \\
403 & Dispersed habitation & medium & C. nigra \\
243 & Trapping, poisoning, poaching & medium & N. percnopterus \\
\hline
\end{tabular}




\subsubsection{Pelagonia}

\section{General information}

Name in English: Pelagonia

Name in Macedonian: Pelagonija (Пелагонија)

IBA code: $\mathrm{MK} 024$

Criteria: A1, A4ii, B1iii, B2, B3

Area: 113,584 ha

Central coordinates: $21^{\circ} 27^{\prime} 42.20^{\prime \prime} \mathrm{E}, 41^{\circ} 11^{\prime} 59.19^{\prime \prime} \mathrm{N}$

Altitude: $590-1,538 \mathrm{~m}$ a.s.l.

Administrative region(s): Bitola, Novaci, Mogila, Prilep, Krivogaštani, Dolneni, Kruševo

\section{Site description}

Situated in southern Macedonia and shared with Greece, this tectonic depression has north-south direction, covering ca. $1,200 \mathrm{~km}^{2}$ in total. Starting west of Prilep town, the boundary runs north to the village of Mažučište, follows the ridge with the peaks Ridot (794 $\mathrm{m}$ a.s.l.) and Negrea (988 $\mathrm{m}$ a.s.l.), reaches the village Zabrčani, turns NE to the village Dupjacani, then WNW to Desovo, follows the mountain slopes around the village of Brailovo, passes through Slepče village, then west to the village of Kostinci, follows the road WSW to the village Slavej, continues along the road to Rilevo village, and then to the village of Žabjani. Here it turns NW to the village Debrešte (locality Gradište), then south through Slatina and Lozina localities, bypassing the village of Lažani, continues SW to Žitoše village, and then follows the road south to the villages of Lokveni, Godivje and Korenica. The boundary continues west of the village Krivogaštani and east of the village Vrboec, passes through the village of Sveto Mitrani and continues south through Mileševo and Presil villages, till it reaches the Crna Reka River. It embraces the locality Loj in the Crna Reka Valley west of the village Bučin, and from here continues SSW to the village Trnovci, passes east of the village Sveto Todori, reaches the village Ivanjevci and continues SE to Vašarejca. Running parallel with it and then following the road, it reaches western part of the village of Mogila, then follows the channel towards Karamani village and continues south, avoiding the villages of Logovardi and Poeševo, to the village Kravari. From here it follows the road to the south, embraces the village Žabjani, passes through the villages of Porodin and Lažec to the border with Greece. Then it follows the national border towards the east until it reaches southern part of the village Živojno, and turns north through Živojno, Dobroveni and west of Skočivir. From here it follows the mountain ridge of Selečka Planina and continues through the village of Gnileš. Here it

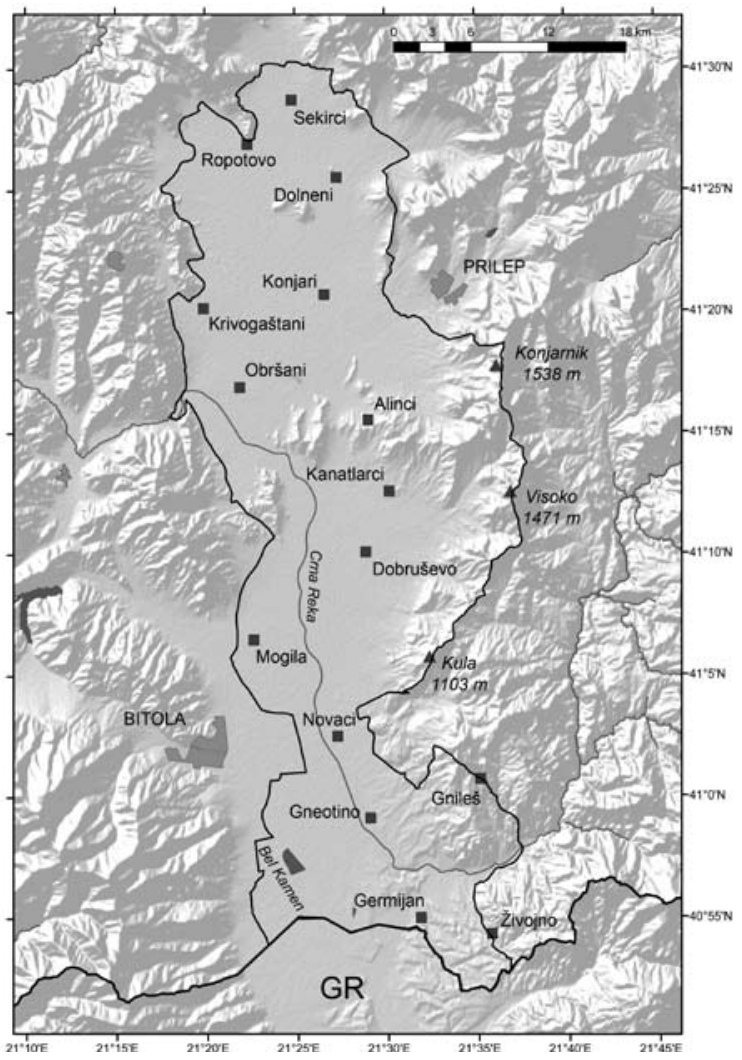

Figure 41: Map of the IBA Pelagonia with its main features depicted

Slika 41: Zemljevid IBA Pelagonija z glavnimi značilnostmi območja

turns NW, continues south of the village Paralovo and through the village Baldovenci, when reaching the Tepovska Reka stream. Then it follows the road in NW direction to the south of Biljanik village, embraces the coal mine "Suvodol" and reaches the village Meglenci, from where it runs NW and after ascending to the Selečka Planina again reaches, after passing through the localities Kula (1,103 m a.s.l.), Kalugjer (1,022 m a.s.l.) and Lisičarnik (1,025 $\mathrm{m}$ a.s.l.), the main ridge of Golema Gramada Mt (1,050 m a.s.l.). Then it continues north through the peaks of Kozjak (983 m a.s.l.), Liljak (999 m a.s.l.), Bobište (1,266 m a.s.l.), Murgova Niva (1,177 m a.s.l.), Visoko (1,471 m a.s.l.), Skala (1,177 m a.s.l.), Dve Steni (1,473 m a.s.l.) and Konjarnik (1,538 m a.s.l.), where it turns west through Šuti Vrv (1,277 m a.s.l.), descends to the plain again, and passes Prilep at its southern side.

The site constitutes the bottom of the Pelagonia Valley and, in the eastern part, the edge (western parts) of Selečka Planina Mt. Geologically, it is dominated 
M. Velevski, B. Hallmann, B. Grubač, T. Lisičanec, E. Stoynov, E. Lisičanec, V. Avukatov, L. Božič \& B. Stumberger: Important Bird Areas in Macedonia: Sites of Global and European Importance

Table 62: List of triggering and other important bird species in the IBA Pelagonia

Tabela 62: Seznam kvalifikacijskih in drugih pomembnih vrst ptic v IBA Pelagonija

\begin{tabular}{lccccc}
\hline $\begin{array}{l}\text { Species/ } \\
\text { Vrsta }\end{array}$ & $\begin{array}{c}\text { Season/ } \\
\text { Sezona }\end{array}$ & $\begin{array}{c}\text { Year/ } \\
\text { Leto }\end{array}$ & $\begin{array}{c}\text { Population/ } \\
\text { Populacija }\end{array}$ & $\begin{array}{c}\text { Acc./ } \\
\text { Zan. }\end{array}$ & $\begin{array}{c}\text { Criteria/ } \\
\text { Kriteriji }\end{array}$ \\
\hline Falco naumanni & $\mathbf{B}$ & $\mathbf{2 0 0 2}$ & $\mathbf{7 6 0 - 8 5 0}$ & $\mathbf{A}$ & A4ii, B1iii, B2 \\
Coracias garrulus & $\mathbf{B}$ & $\mathbf{2 0 0 2}$ & $\mathbf{I 0 - 3 0}$ & $\mathbf{C}$ & A1, B2 \\
Ciconia ciconia & $\mathbf{B}$ & $\mathbf{2 0 0 2}$ & $\mathbf{2 2 0 - 2 3 0}$ & $\mathbf{A}$ & $\mathbf{B 2}$ \\
Aythya nyroca & $\mathbf{B}$ & $\mathbf{2 0 0 2}$ & $\mathbf{I 0 - 1 5}$ & $\mathbf{A}$ & $\mathbf{B 2}$ \\
Burbinus oedicnemus & $\mathbf{B}$ & $\mathbf{2 0 0 2}$ & $\mathbf{I 0 - 3 0}$ & $\mathbf{C}$ & $\mathbf{B 2}$ \\
Lanius minor & $\mathbf{B}$ & $\mathbf{2 0 0 2}$ & $\mathbf{3 0 - 1 0 0}$ & $\mathbf{C}$ & $\mathbf{B 2}$ \\
Circus pygargus & $\mathbf{B}$ & $\mathbf{2 0 0 2}$ & $\mathbf{6 0 - 8 0}$ & $\mathbf{A}$ & $\mathbf{B 3}$ \\
Falco vespertinus & $\mathrm{P}$ & 2002 & $50-150$ ind. & $\mathrm{C}$ & $\mathrm{A} 1$ ? \\
Pelecanus crispus & $\mathrm{N}$ & 2007 & $10-30$ ind. & $\mathrm{C}$ & $\mathrm{N}$ \\
Anas strepera & $\mathrm{B}$ & 2002 & $2-5$ & $\mathrm{C}$ & $\mathrm{N}$ \\
Circaetus gallicus & $\mathrm{B}$ & 2008 & $2-3$ & $\mathrm{~B}$ & $\mathrm{~N}$ \\
Buteo rufinus & $\mathrm{R}$ & 2010 & $3-4$ & $\mathrm{~B}$ & $\mathrm{~N}$ \\
Falco biarmicus & $\mathrm{B}$ & 2005 & $\mathrm{I}$ & $\mathrm{A}$ & $\mathrm{N}$ \\
\hline
\end{tabular}

by Pliocene lake sediments, Precambrian magmatites and metamorphytes in Selečka Planina Mt. The largest river is the Crna Reka in the southern part of the site (Figure 41).

\section{Species}

No thorough information on the site's bird community has been published recently, although numerous

Table 63: The main CORINE land cover types (Level 3) in the IBA Pelagonia

Tabela 63: Glavni tipi pokrovnosti in rabe tal (po CORINE land cover, 3. nivo) v IBA Pelagonija

\begin{tabular}{llc}
\hline $\begin{array}{l}\text { Code/ } \\
\text { Koda }\end{array}$ & $\begin{array}{l}\text { CORINE land cover type/ } \\
\text { tip pokrovnosti in rabe tal }\end{array}$ & $\begin{array}{c}\text { Coverage/ } \\
\text { Pokrovnost (\%) }\end{array}$ \\
\hline II2 & Discontinuous urban fabric & I.5 \\
2II & Non-irrigated arable land & 47.9 \\
2I2 & Permanently irrigated land & $2 \mathrm{I} .4$ \\
242 & Complex cultivation patterns & 7.3 \\
243 & Land principally occupied by & I.2 \\
& agriculture, with significant & \\
& areas of natural vegetation & \\
23I & Pastures & I2.9 \\
3II & Broad-leaved forest & I.5 \\
32I & Natural grasslands & 0.6 \\
324 & Transitional woodland-shrub & 4.5 \\
5I2 & Water bodies & 0.4 \\
4II & Inland marshes & $0 . \mathrm{I}$ \\
& Other & 0.5 \\
\hline
\end{tabular}

data were collected during the Lesser Kestrel and White Stork censuses in 2002 (B. ŠTUMBERGER \& M. VelevsKi unpubl.). Ample information, however, is available from earlier periods (1940-1970) (e.g. MaKatsch I950, Terrasse \& Terrasse I96ia \& I96IB, GANSO 1962). The currently drained floodplain of the Crna Reka held numerous breeding colonial waterbirds in the 1930s, the most interesting being up to 100 breeding pairs of Dalmatian Pelican, 60+ pairs of Spoonbill Platalea leucorodia, tens of breeding Glossy Ibises Plegadis falcinellus and ca. 300 pairs of Black Tern Chlidonias niger (MAKATSCH 1950, THÖNEN 2006); none of these species breed in the territory of Macedonia at present.

In 2002, an important population (largest in the country) of White Stork was confirmed, breeding solitarily or in small colonies of up to 20 pairs (ŠTUMBerger \& VelevsKi 2002). Lesser Kestrel population was estimated at $760-850$ pairs, entirely confined to villages and man-made structures in the central and northern parts of the plain, but using mountain slopes (especially those of Mt Seleckka Planina) for foraging. At least two pairs of Longlegged Buzzards breed on cliffs of these slopes, and one more on a small hill in the plain. Several other species reach the threshold for populations of European importance, including the Montagu's Harrier with the largest breeding population in the country $(60-80$ pairs). The three fishponds (Bel Kamen and Bukri in the south and Belo Pole in the north) attract nonbreeding Dalmatian Pelicans, and are important for the breeding Ferruginous Duck and few pairs of 


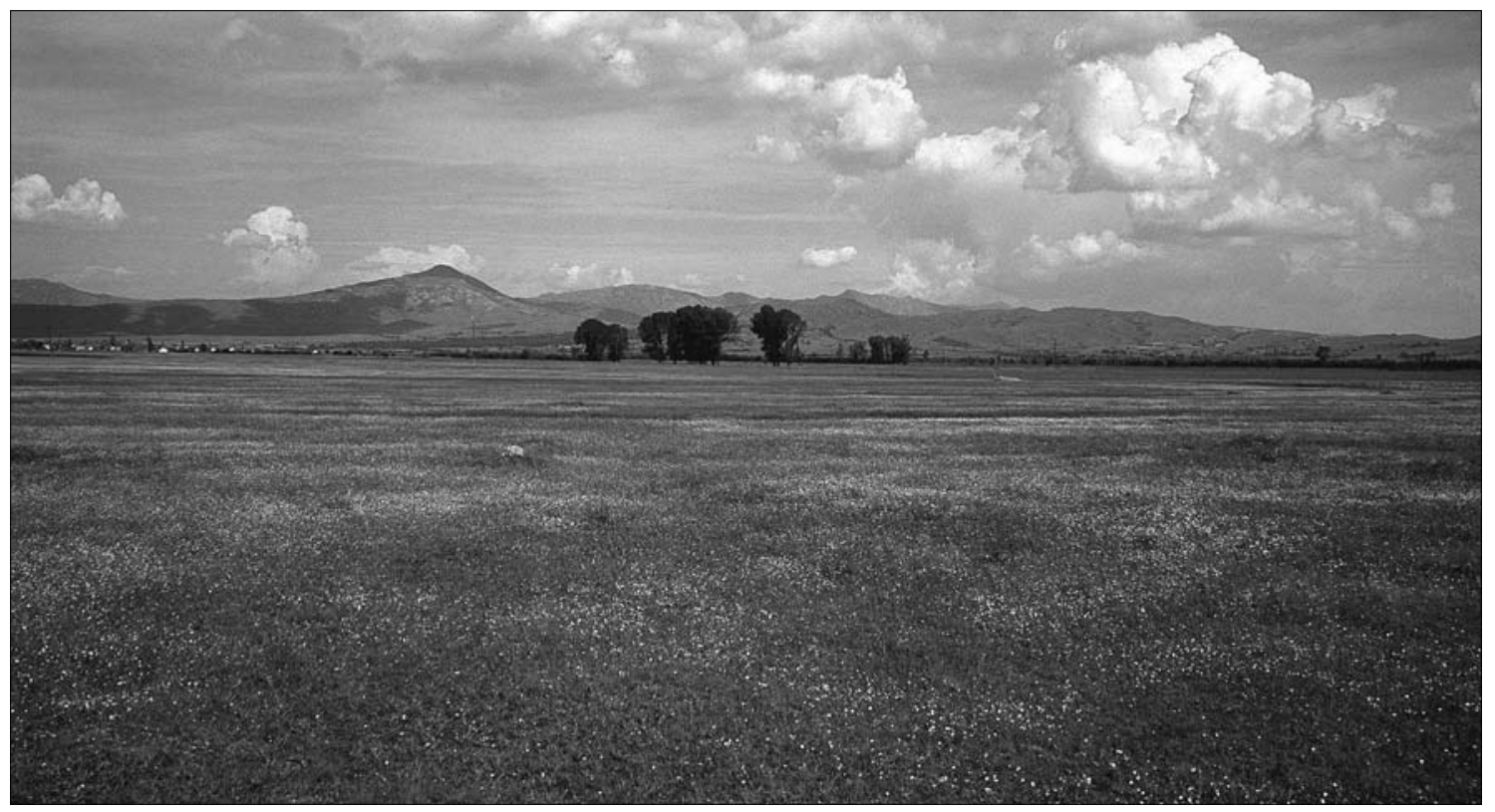

Figure 42: Characteristic landscape of the IBA Pelagonia (photo: B. Stumberger)

Slika 42: Značilna krajina IBA Pelagonija (foto: B. Stumberger)

Gadwalls (Table 62). Importance of the fishponds for migrating and wintering species is still insufficiently known, although it is presumably high.

\section{Habitats and land use}

The bottom of the Pelagonian depression is used for agricultural purposes, more intensively in the south than in the central and northern parts, where dry and wet meadows and pastures remain. Several poplar tree stands are scattered throughout the landscape, and some remains of the former wetlands can be found. Three fishponds are located within the site. On the eastern edge of the site, the slopes of $\mathrm{Mt}$ Selečka are dominated by dry pastures and remains of thermophyllous oak forests, among which silicate cliffs protrude (Table 63, Figure 42).

\section{Threats}

Formerly, the drainage of marshlands of the Crna Reka River caused significant changes in the composition of the site's bird fauna, although presently this process is considered finished. Due to the intensive agriculture in southern parts of the site, use of fertilizers and pesticides is presumably high. Parts of the site are monocultures with low diversity of birds, and their expansion in the plain's northern and central parts might have devastating effects on the populations of the triggering species.

Table 64: The main threats to birds and their importance in the IBA Pelagonia

Tabela 64: Najpomembnejši dejavniki ogrožanja ptic in njihov vpliv v IBA Pelagonija

\begin{tabular}{|c|c|c|c|}
\hline $\begin{array}{l}\text { Code/ } \\
\text { Koda }\end{array}$ & $\begin{array}{c}\text { Threat/ } \\
\text { Dejavnik ogrožanja }\end{array}$ & $\begin{array}{l}\text { Threat impact/ } \\
\text { Vpliv }\end{array}$ & $\begin{array}{l}\text { Most affected species/ } \\
\text { Najbolj prizadete vrste }\end{array}$ \\
\hline 100 & Cultivation & high & C. ciconia, F. naumanni, C. garrulus, L. minor \\
\hline IIo & Use of pesticides & high & C. ciconia, F. naumanni, C. garrulus, L. minor \\
\hline I4I & Abandonment of pastoral systems & high & F. naumanni \\
\hline SII & Electricity lines & high & C. ciconia, F. naumanni, C. garrulus \\
\hline 803 & $\begin{array}{l}\text { Infilling of ditches, dykes, ponds, } \\
\text { marshes or pits }\end{array}$ & high & C. ciconia \\
\hline
\end{tabular}


M. Velevski, B. Hallmann, B. Grubač, T. Lisičanec, E. Stoynov, E. Lisičanec, V. Avukatov, L. Božič \& B. Stumberger: Important Bird Areas in Macedonia: Sites of Global and European Importance

Livestock numbers have decreased, causing changes in the pastures (overgrowing). Hunting is present, but poaching seems rare. Electrocution causes some mortality, especially in White Storks (Table 64).

\section{Conservation}

The site includes a very small strictly protected area (Lokvi), and parts of the Markovi Kuli Nature Monument. Establishment of protected area has not been formally planned, although most important parts of the site are included in the Emerald Network (“Gorna Pelagonija”, MK0000034). Most important for Pelagonian birds are programs preserving and developing different temperate grassland types. Implementation of autochthonous breeds of domestic animals like water buffalo, sheep, shorthorned cattle (Busha) and horses in landscape management is essential to preserve the Pelagonian large scale pasture systems.

\subsubsection{Mariovo}

\begin{tabular}{l}
\hline General information \\
Name in English: Mariovo \\
Name in Macedonian: Mariovo (Мариово) \\
IBA code: MK025 \\
Criteria: A1, A3, B2 \\
Area: 63,272 ha \\
Central coordinates: $21^{\circ} 42^{\prime} 34.41^{\prime} \mathrm{E}, 41^{\circ} 09^{\prime} 46.93^{\prime} \mathrm{N}$ \\
Altitude: $302-1,643 \mathrm{~m}$ a.s.l. \\
Administrative region(s): Novaci, Prilep, Kavadarci, \\
Mogila
\end{tabular}

\section{Site description}

Situated in southern Macedonia, this site includes SW part of the former site "Crna River Gorge" (MK007, Heath \& Evans 2000). Starting from the peak Kalusovec (1,446 m a.s.l.) on Selečka Planina Mt SE of Prilep to the south, it shares the boundary with the Pelagonia site (MK024) to the locality Lisičarnik (1,025 $\mathrm{m}$ a.s.l.) and the passes at Preslop, Smeč (1,303 m a.s.l.) and Gola Čuka (1,338 $\mathrm{m}$ a.s.l.). The boundary continues through the villages of Grumazi and Gnileš, where it again joins the common boundary with Pelagonia running south to the Crna Reka River. Here it turns NE, follows first the river and then the road to the village of Budimirci. Then it follows the Bela Reka River for a short while, turns NE and crosses the hill of Kameni Vrv (1,151 $\mathrm{m}$ a.s.l.), the Lešnica and Gradešnička Reka Rivers east of Gradešnica village, turns NW, follows the Porenica River, then runs through Sekulova Tumba $(1,057 \mathrm{~m}$

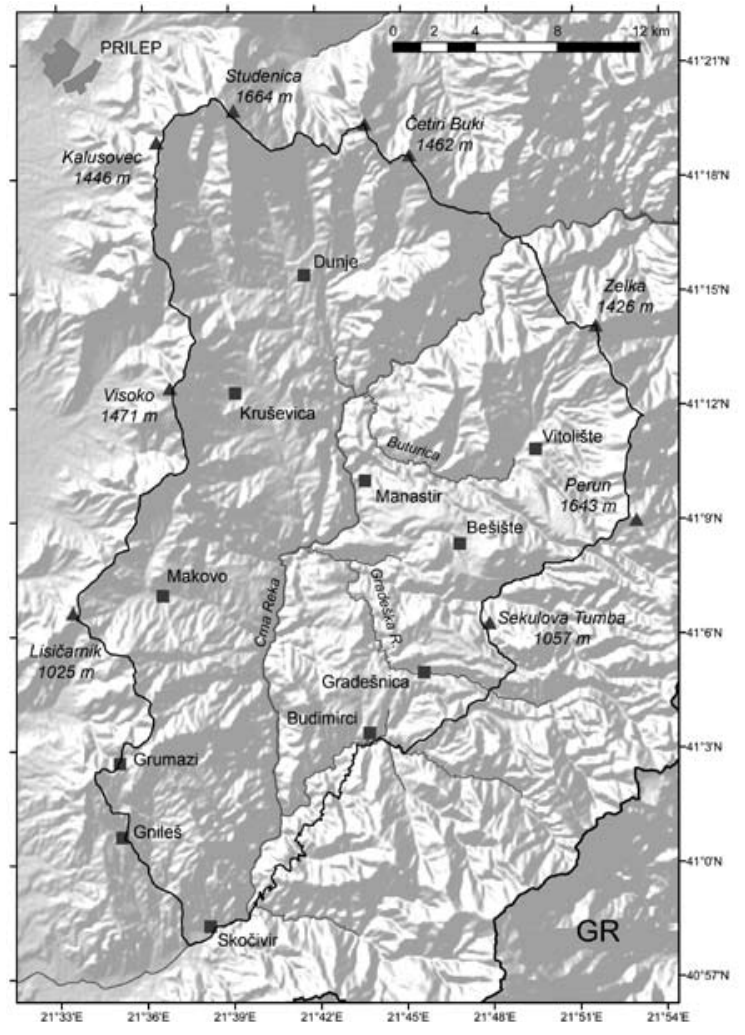

Figure 43: Map of the IBA Mariovo with its main features depicted

Slika 43: Zemljevid IBA Mariovo z glavnimi značilnostmi območja

a.s.l.), crosses the Potokot River and continues NE to the peak of Perun (1,643 $\mathrm{m}$ a.s.l.). From here it follows the mountain ridge north to the peaks of Zelka $(1,426$ $\mathrm{m}$ a.s.l.) and Vragovec (1,107 $\mathrm{m}$ a.s.l.), from where it descends to the Crna Reka River again, crosses it below the village of Gudjakovo, continues through this village in NW direction to the peaks of Trite Stragi $(1,476 \mathrm{~m}$ a.s.l.), Četiri Buki (1,462 m a.s.l.) and Markovi Kuli (1,510 $\mathrm{m}$ a.s.l.), turns west to the Golina and Ligurasa passes, and again NW to the peak Studenica $(1,664 \mathrm{~m}$ a.s.l.). Still following the ridge, the boundary turns SW to the peak Kalusovec again.

The site is constituted of the Mariovo Valley, which does not have a flat bottom, as it is broken by the valleys of the Crna Reka River and its tributaries Bela Reka, Buturica, Lisička Reka, etc. It embraces several mountains-Selečka, Nidže, Kozjak and Dren. Pliocene and Miocene lake sediments are found in the site's lowest parts, while the rest is formed by Precambrian metamorphic and magmatic rocks. The Crna Reka Valley includes the remarkable Skočivir Gorge, with 
Table 65: List of triggering and other important bird species in the IBA Mariovo

Tabela 65: Seznam kvalifikacijskih in drugih pomembnih vrst ptic v IBA Mariovo

\begin{tabular}{|c|c|c|c|c|c|}
\hline $\begin{array}{l}\text { Species/ } \\
\text { Vrsta }\end{array}$ & $\begin{array}{l}\text { Season/ } \\
\text { Sezona }\end{array}$ & $\begin{array}{l}\text { Year/ } \\
\text { Leto }\end{array}$ & $\begin{array}{c}\text { Population/ } \\
\text { Populacija }\end{array}$ & $\begin{array}{l}\text { Acc./ } \\
\text { Zan. }\end{array}$ & $\begin{array}{l}\text { Criteria/ } \\
\text { Kriteriji }\end{array}$ \\
\hline Neophron percnopterus & B & 2009 & 4 & A & A1, B2 \\
\hline Alectoris graeca & $\mathbf{R}$ & & Frequent & & A3 \\
\hline Oenanthe hispanica & B & & Common & & A3 \\
\hline Sylvia cantillans & B & & Frequent & & A3 \\
\hline Sitta neumayer & $\mathbf{R}$ & & Abundant & & A3 \\
\hline Lanius nubicus & B & & Rare & & A3 \\
\hline Emberiza melanocephala & B & & Common & & A3 \\
\hline Ciconia nigra & B & 2009 & $2-3$ & B & B2 \\
\hline Circaetus gallicus & B & 2007 & $8-1 I$ & B & B2 \\
\hline Buteo rufinus & $\mathbf{R}$ & 2009 & $8-12$ & B & B2 \\
\hline Aquila chrysaetos & $\mathbf{R}$ & 2009 & $4-6$ & B & B2 \\
\hline Falco naumanni & B & 2003 & $120-150$ & B & B2 \\
\hline Falco biarmicus & B & 2006 & $\mathbf{I}-\mathbf{2}$ & B & B2 \\
\hline Bubo bubo & $\mathbf{R}$ & 2009 & $5-7$ & C & B2 \\
\hline Monticola saxatilis & B & 2002-2010 & $30-50$ & C & $\mathbf{B 2}$ \\
\hline Falco tinnunculus & $\mathrm{R}$ & & Common & & B2? \\
\hline Gyps fulvus & $\mathrm{R}$ & 2010 & $8-9$ & A & $\mathrm{N}$ \\
\hline Accipiter brevipes & B & 2006 & $\mathrm{I}-3$ & $\mathrm{C}$ & $\mathrm{N}$ \\
\hline Aquila pennata & B & 2006 & O-I & $\mathrm{C}$ & \\
\hline Aquila heliaca & $\mathrm{R}$ & 2006 & O-I & $\mathrm{C}$ & \\
\hline Falco peregrinus & $\mathrm{R}$ & 2009 & $\mathrm{I}-3$ & $\mathrm{C}$ & $\mathrm{N}$ \\
\hline
\end{tabular}

Table 66: The main CORINE land cover types (Level 3) in the IBA Mariovo

Tabela 66: Glavni tipi pokrovnosti in rabe tal (po CORINE land cover, 3. nivo) v IBA Mariovo

\begin{tabular}{llc}
\hline $\begin{array}{l}\text { Code/ } \\
\text { Koda }\end{array}$ & $\begin{array}{l}\text { CORINE land cover type/ } \\
\text { tip pokrovnosti in rabe tal }\end{array}$ & $\begin{array}{c}\text { Coverage/ } \\
\text { Pokrovnost (\%) }\end{array}$ \\
\hline 242 & Complex cultivation patterns & 4.7 \\
$23 \mathrm{I}$ & Pastures & 24.6 \\
$3 \mathrm{II}$ & Broad-leaved forest & $\mathrm{I} 6.4$ \\
$32 \mathrm{I}$ & Natural grasslands & $\mathrm{I} 2.9$ \\
323 & Sclerophyllous vegetation & 0.6 \\
324 & Transitional woodland-shrub & 36.6 \\
& Other & $4 . \mathrm{I}$ \\
\hline
\end{tabular}

some of the Crna Reka's tributaries forming gorges in the lower sections as well (e.g. Gradešnička Gorge, Buturica Gorge) (Figure 43).

\section{Species}

There are relatively few published data (e.g. Grubač 1989, I997 \& 1999) on the bird fauna of Mariovo, although the region has been quite well studied, with about 140 species recorded. It is of great significance for the populations of Griffon (8-9 pairs) and Egyptian Vultures (4 pairs), which are at present the only stable populations in the country. Other birds of prey, especially Golden Eagle (4-6 pairs), Lesser Kestrel (120-150 pairs), Long-legged Buzzard (8-12 pairs), Lanner Falcon (1-2 pairs) and Short-toed Eagle (8-11 pairs), breed here in good numbers, too. The site probably holds populations of some other species that meet B2 thresholds, i.e. Common Kestrel. Species characteristic of the Mediterranean biome include large populations of Black-headed Bunting, Subalpine Warbler, Rock Nuthatch, and a few pairs of Masked Shrike. Furthermore, 2-3 pairs of Black Stork breed here, and possibly a single pair of Imperial Eagle (Table 65). The first record of the Steppe Eagle Aquila nipalensis for Macedonia (one ind. on I5 Jul 2002 near the village of Rapeš, B. Hallmann unpubl.) comes from this region.

\section{Habitats and land use}

The landscape is dominated by large silicate rocks and cliffs in the gorge of Crna Reka River. Formerly 
M. Velevski, B. Hallmann, B. Grubač, T. Lisičanec, E. Stoynov, E. Lisičanec, V. Avukatov, L. Božıč \& B. Stumberger: Important Bird Areas in Macedonia: Sites of Global and European Importance

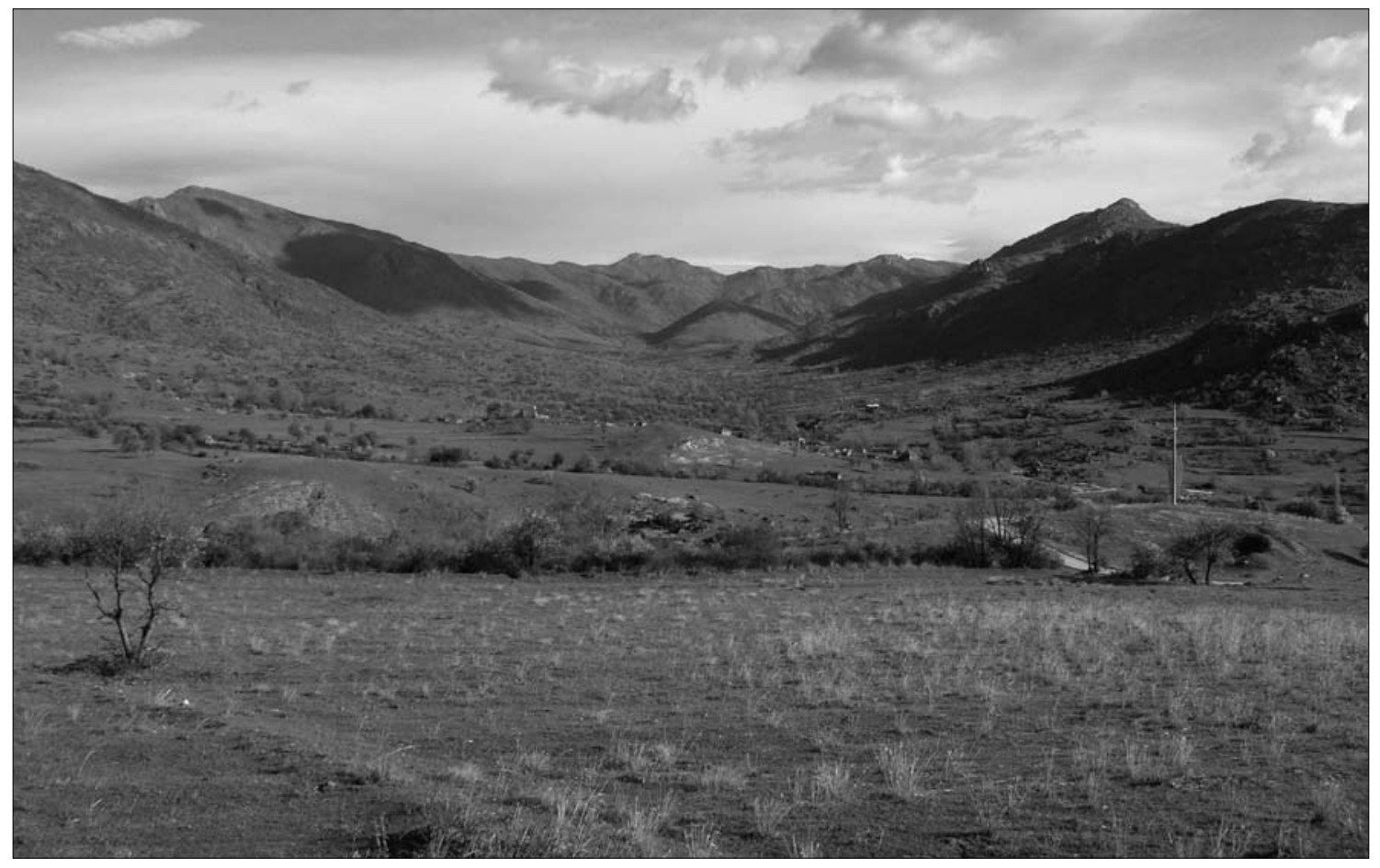

Figure 44: Characteristic landscape of the IBA Mariovo (photo: M. Velevski)

Slika 44: Značilna krajina IBA Mariovo (foto: M. Velevski)

extensively used for agriculture and livestock breeding, this region is now slowly returning to the climax oak forests, while part of the agricultural fields has been converted into dry pastures. The riparian vegetation along the Crna Reka River is composed of poplar and willow. Some pine plantations can also be found (Table 66, Figure 44).

\section{Threats}

Two large hydro-power plants are foreseen to be constructed on the Crna Reka River in the near future, which would submerge part of the cliffs suitable for breeding of Griffon and Egyptian Vultures and increase accessibility to other locations. Stone-mining is widespread, although so far practiced at appropriate

Table 67: The main threats to birds and their importance in the IBA Mariovo

Tabela 67: Najpomembnejši dejavniki ogrožanja ptic in njihov vpliv v IBA Mariovo

\begin{tabular}{|c|c|c|c|}
\hline $\begin{array}{l}\text { Code/ } \\
\text { Koda }\end{array}$ & $\begin{array}{c}\text { Threat/ } \\
\text { Dejavnik ogrožanja }\end{array}$ & $\begin{array}{l}\text { Threat impact/ } \\
\text { Vpliv }\end{array}$ & $\begin{array}{l}\text { Most affected species/ } \\
\text { Najbolj prizadete vrste }\end{array}$ \\
\hline I4I & Abandonment of pastoral systems & high & G. fulvus, $N$. percnopterus, $A$. heliaca \\
\hline 243 & Trapping, poisoning, poaching & high & G. fulvus, $N$. percnopterus, $A$. heliaca \\
\hline 960 & Interspecific faunal relations & high & A. chrysaetos, A. heliaca \\
\hline 230 & Hunting & high & G. fulvus, A. graeca \\
\hline 3OI & Quarries & medium & A. graeca \\
\hline $4 \mathrm{IO}$ & Industrial or commercial areas & medium & $\begin{array}{l}\text { G. fulvus, } N \text {. percnopterus, } \\
\text { A. chrysaetos, B. rufinus, A. graeca }\end{array}$ \\
\hline 530 & Improved access to site & medium & A. graeca \\
\hline 624 & $\begin{array}{l}\text { Mountaineering, rock climbing, } \\
\text { speleology }\end{array}$ & low & G. fulvus \\
\hline
\end{tabular}


distances from the area's key localities. Depopulation of villages has been intensive in the past, resulting in decrease in livestock numbers and overgrowing of pastures. Hunting and poaching are common, and poison use, aimed at carnivore control, has been recorded regularly, in turn leading to the death of 19 Griffon Vultures in 2007. Plans exist for the opening of new coal mine, and even for the construction of a nuclear power plant. Hunting causes, besides direct killing of Rock Partridges, disturbance at the breeding sites of Griffon Vultures and decrease in the prey base of other important species (Table 67).

\section{Conservation}

Surprisingly, besides all development plans and exploitation activities in the region, parts of the region are foreseen to be given the status of protected area. Presently, the canyon of Gradešnička Reka River is under protection as a Nature Monument, along with another very small paleontological locality (Manastir). The IBA largely overlaps the proposed Emerald Site (MK0000032).

\subsubsection{Lake Tikveš}

\section{General information}

Name in English: Lake Tikveš

Name in Macedonian: Tikveško Ezero (Тиквешко Езеро)

IBA code: $\mathrm{MK} 026$

Criteria: A1, A3, B2

Area: 26,688 ha

Central coordinates: $21^{\circ} 57^{\prime} 28.87^{\prime \prime} \mathrm{E}, 41^{\circ} 18^{\prime} 36.30^{\prime \prime} \mathrm{N}$

Altitude: $260-1,480 \mathrm{~m}$ a.s.l.

Administrative region(s): Kavadarci, Prilep

\section{Site description}

This is another site in southern Macedonia, located SW of the town of Kavadarci. It occupies the northern part of the former "Crna River Gorge" site (MK007, Heath \& Evans 2000). Starting at the artificial Lake Tikveš shore near the island of Gradište on the northern end of the lake, the boundary runs west following the Drenovica River to Dradnja village and leaving part of the lake outside the site, from where it shares the boundary with the Raec River Valley site (MK023), going SW and south to the ridge west of the village of Galište. From here, following the same ridge south, it crosses Lake Tikveš to the influx of the Crna Reka River, reaching the peak of Nedelka (843 $\mathrm{m}$ a.s.l.) and turning east at the ridge Varelova Tumba (769 $\mathrm{m}$ a.s.l.). Thereupon it continues south,

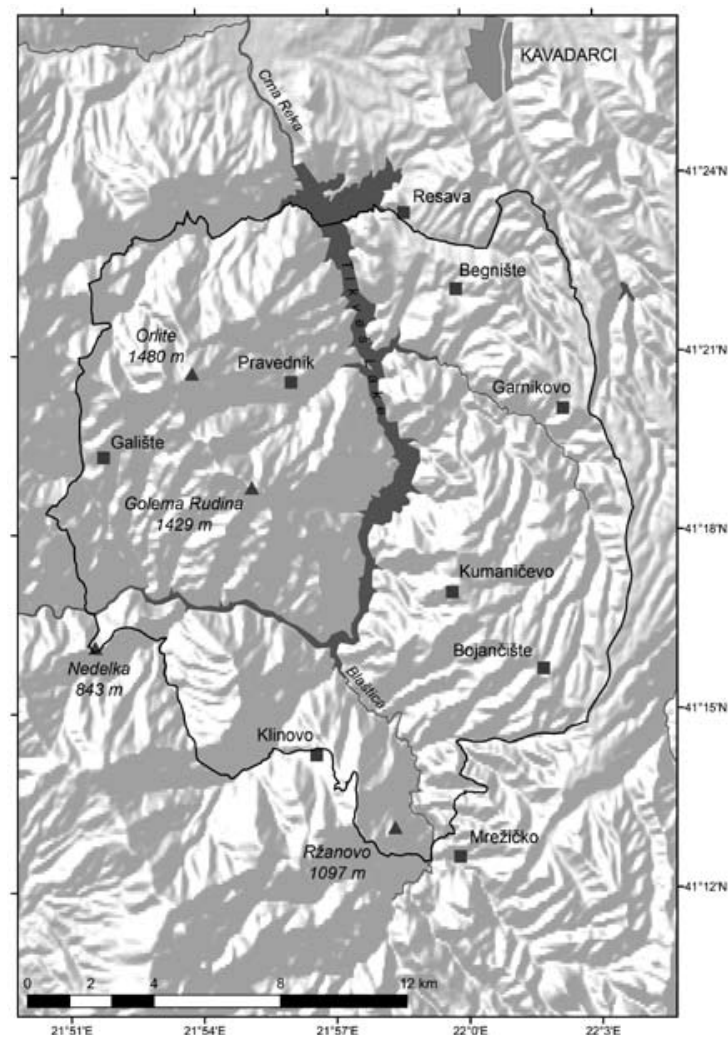

Figure 45: Map of the IBA Lake Tikveš with its main features depicted

Slika 45: Zemljevid IBA Tikveško jezero z glavnimi značilnostmi območja

following the rivulet that springs under the ridge of Golem Draguj, passes the saddle and after a short while follows the Došnica River NE to the locality Grkovite Nivi. Here it turns east, avoiding Klinovo village, and continues south to the peak of Ržanovo $(1,097$ $\mathrm{m}$ a.s.l.). Then it follows the ridge of Čatino, turns east and crosses the Blašnica River west of Mrežičko village. From here it continues NE and through the localities Ramnište and Elata, when it reaches the Parnapeš rivulet, following it upstream and east to the road on the Vitačevo plateau. This road, running north, shares the boundary with the Bošavija site (MK027), to the crossroads at Stragovo village. The IBA Lake Tikveš boundary continues north following the same road until it reaches the locality Kozarinov Kamen (in this section, the boundary is shared with the Tikveš Region site, MK013), from where it turns west to the villages of Dabnište and Resava, reaching the shores of Lake Tikveš again.

Mt Orlite occupies the western parts, Mt Kožuf 
M. Velevski, B. Hallmann, B. Grubač, T. Lisičanec, E. Stoynov, E. Lisičanec, V. Avukatov, L. Božič \& B. Stumberger: Important Bird Areas in Macedonia: Sites of Global and European Importance

Table 68: List of triggering and other important bird species in the IBA Lake Tikveš

Tabela 68: Seznam kvalifikacijskih in drugih pomembnih vrst v IBA Tikveško jezero

\begin{tabular}{|c|c|c|c|c|c|}
\hline $\begin{array}{l}\text { Species/ } \\
\text { Vrsta }\end{array}$ & $\begin{array}{l}\text { Season/ } \\
\text { Sezona }\end{array}$ & $\begin{array}{l}\text { Year/ } \\
\text { Leto }\end{array}$ & $\begin{array}{c}\text { Population/ } \\
\text { Populacija }\end{array}$ & $\begin{array}{l}\text { Acc./ } \\
\text { Zan. }\end{array}$ & $\begin{array}{l}\text { Criteria/ } \\
\text { Kriteriji }\end{array}$ \\
\hline Neophron percnopterus & B & 2010 & 3 & A & A1, B2 \\
\hline Alectoris graeca & $\mathbf{R}$ & 2009 & $20-50$ & C & A3 \\
\hline Oenanthe hispanica & B & & Common & & A3 \\
\hline Sylvia cantillans & B & & Abundant & & A3 \\
\hline Sitta neumayer & $\mathbf{R}$ & & Frequent & & A3 \\
\hline Emberiza melanocephala & B & & Frequent & & A3 \\
\hline Ciconia nigra & B & 2010 & $2-3$ & B & B2 \\
\hline Circaetus gallicus & B & 2009 & $5-8$ & B & B2 \\
\hline Buteo rufinus & $\mathbf{R}$ & 2009 & $4-5$ & B & B2 \\
\hline Aquila chrysaetos & $\mathbf{R}$ & 2009 & $3-4$ & B & B2 \\
\hline Falco naumanni & B & 2003 & $70-100$ & $\mathbf{A}$ & B2 \\
\hline Monticola solitarius & B & 2003-2010 & $20-50$ & C & B2 \\
\hline Gyps fulvus & $\mathrm{R}$ & 2007-2010 & $5-9$ & A & $\mathrm{N}$ \\
\hline Aquila pomarina & B & 2010 & $0-2$ & $\mathrm{C}$ & \\
\hline Milvus migrans & B & 2007 & I & A & $\mathrm{N}$ \\
\hline Accipiter brevipes & B & 2008 & $0-2$ & $\mathrm{C}$ & \\
\hline Falco peregrinus & $\mathrm{R}$ & 2009 & $3-4$ & $\mathrm{~B}$ & $\mathrm{~N}$ \\
\hline Bubo bubo & $\mathrm{R}$ & 2009 & $4-8$ & B & $\mathrm{N}$ \\
\hline
\end{tabular}

the southern parts and Vitačevo plateau the eastern parts of the site. Geologically, Mesozoic formations are dominant, i.e. Triassic, Jurassic and Cretaceous metamorphic and magmatic rocks with significant presence of Mesozoic carbonates. Vitačevo is composed of volcanic tuffs. The Crna Reka River forms the main gorge, its major tributary being the Blašnica River (Figure 45).

\section{Species}

The area of Lake Tikveš has been well studied, with the total number of observed species reaching 176 . The number of vagrant species on the Lake is large (VAsIć 2009B), but the carried out winter censuses have shown that it is not of international nor national importance for wintering waterbirds (up to 670 ind. in 2009 and 280 in 20IO, VAsić 2009B, Farmahem 20IO). However, its surrounding has long been recognized as a place of great importance for the raptors - it has been the last known breeding place of the Lammergeier Gypaetus barbatus in Macedonia (GRUBAČ I990), breeding until 1984 and the surviving male being present there until 2005-2006. The Griffon Vulture colony decreased from nine to five pairs in the last few years, although still probably numbering around 20 pairs in the late 1990s (B. GrubaČ unpubl.). Currently, the only three breeding pairs of Egyptian Vulture signify a decrease from 10 pairs in 1991 (B. Grubač unpubl.). Other raptor species include Lesser Kestrel (70-100 pairs), Golden Eagle (3-4 pairs), Short-toed Eagle (5-8 pairs), Long-legged Buzzard (4-5 pairs), Peregrine Falcon and Eagle Owl. Large populations of five species characteristic of the Mediterranean biome are found here. A small colony of Alpine Choughs (2030 pairs) inhabits the highest peaks (Orlite $1,480 \mathrm{~m}$ a.s.l.). Other important or rare species include Black Stork, Black Kite and, until 2006, a single individual

Table 69: The main CORINE land cover types (Level 3) in the IBA Lake Tikveš

Tabela 69: Glavni tipi pokrovnosti in rabe tal (po CORINE land cover, 3. nivo) v IBA Tikveško jezero

\begin{tabular}{llc}
\hline $\begin{array}{l}\text { Code/ } \\
\text { Koda }\end{array}$ & $\begin{array}{l}\text { CORINE land cover type/ } \\
\text { tip pokrovnosti in rabe tal }\end{array}$ & $\begin{array}{c}\text { Coverage/ } \\
\text { Pokrovnost (\%) }\end{array}$ \\
\hline $23 \mathrm{I}$ & Pastures & 5.0 \\
$3 \mathrm{II}$ & Broad-leaved forest & 45.9 \\
$32 \mathrm{I}$ & Natural grasslands & 4.0 \\
323 & Sclerophyllous vegetation & 9.2 \\
324 & Transitional woodland-shrub & 22.2 \\
$5 \mathrm{I} 2$ & Water bodies & 3.4 \\
& Other & I0.2 \\
\hline
\end{tabular}




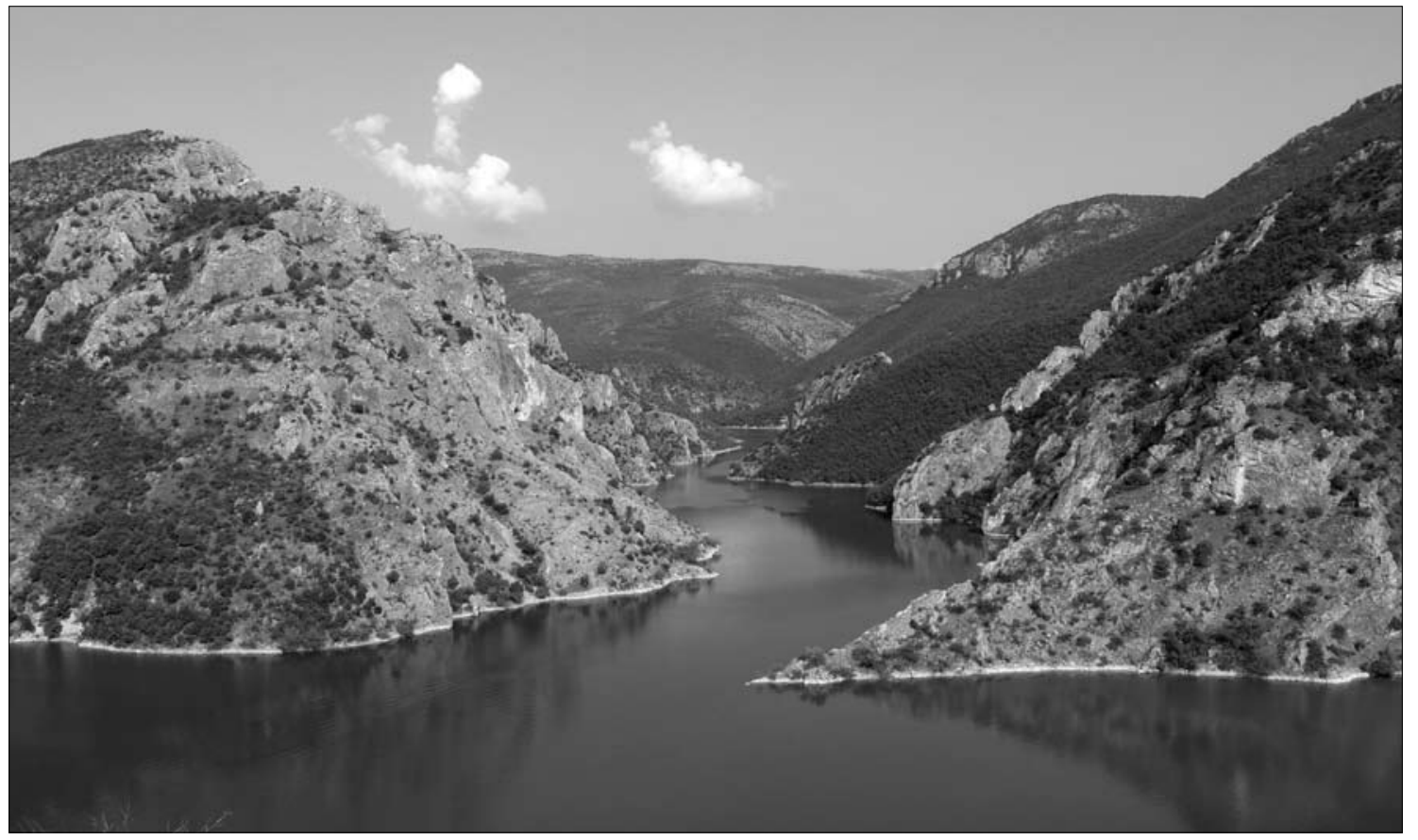

Figure 46: Characteristic landscape of the IBA Lake Tikveš (photo: M. Velevski)

Slika 46: Značilna krajina IBA Tikveško jezero (foto: M. Velevski)

of Black Vulture Aegypius monachus, being the last known individual present in the country. Also, two pairs of Lesser-spotted Eagles breed in or in the near surroundings of the site (Table 68). Imperial Eagles are observed outside the breeding season, and a record of Steppe Eagle Aquila nipalensis exists (two ind. on 14 Jun 2004 on the vulture feeding site at Vitačevo, B. Hallmann unpubl.).

\section{Habitats and land use}

The lowest parts of the site embrace Tikveš reservoir, a long and narrow water body between the slopes overgrown with sub-Mediterranean scrub (Greek Juniper Juniperus excelsa, Downy Oak Quercus pubescens, Mock Privet Phyllirea media). In some parts, well preserved remains of Macedonian Oak Quercus trojana forests exist, while in the southern parts, Black Pine Pinus nigra forests are present. Limestone cliffs are scattered throughout the landscape in the valleys of the Crna Reka, Blašnica and Kamenica Rivers, forming a huge complex together with the peaks of Orlite and Galčin in the centre of the site. Some pastures in different stages of succession have remained on the Vitačevo plateau (Table 69, Figure 46).

Table 70: The main threats to birds and their importance in the IBA Lake Tikveš

Tabela 70: Najpomembnejši dejavniki ogrožanja ptic in njihov vpliv v IBA Tikveško jezero

\begin{tabular}{llll}
\hline $\begin{array}{l}\text { Code/ } \\
\text { Koda }\end{array}$ & \multicolumn{1}{c}{$\begin{array}{c}\text { Threat/ } \\
\text { Dejavnik ogrožanja }\end{array}$} & $\begin{array}{c}\text { Threat impact/ } \\
\text { Vpliv }\end{array}$ & \multicolumn{1}{c}{$\begin{array}{c}\text { Most affected species/ } \\
\text { Najbolj prizadete vrste }\end{array}$} \\
\hline 243 & Trapping, poisoning, poaching & high & G. fulvus, N. percnopterus \\
403 & Dispersed habitation & high & G. fulvus, C. nigra, C. gallicus \\
I4I & Abandonment of pastoral systems & medium & G. fulvus, N. percnopterus \\
I60 & General forestry management & medium & C. nigra, C. gallicus, A. pomarina \\
5II & Electricity lines & medium & G. fulvus, N. percnopterus, F. naumanni \\
\hline
\end{tabular}


M. Velevski, B. Hallmann, B. Grubač, T. Lisičanec, E. Stoynov, E. Lisičanec, V. Avukatov, L. Božič \& B. Stumberger: Important Bird Areas in Macedonia: Sites of Global and European Importance

\section{Threats}

The lake shore is built up by weekend cottages, which are frequently used as bases for illegal fishing and hunting. Intensive forestry activities, including clearcuts, take place. Use of poisonous baits is still common. The Vitačevo plateau is intersected by many power lines, although direct mortality of birds of prey has not been noted (Table 70).

\section{Conservation}

Although parts of the site have been under legal protection as a strict nature reserve since 1997, no management activities have taken place. The new valorization study suggests the site will need to change its protection category into a lower one (i.e. Nature Monument), as it has lost many of its natural assets it used to have. A new management plan was recently prepared by the Ministry of Environment and Physical Planning and UNDP - United Nations Development Programme, but the site does not have a management body. Parts of the IBA are proposed as "Tikvesh" Emerald Site (MK0000006). Supplementary feeding for vultures has been regularly taking place for almost two decades, undertaken by the Aquila Nature Conservation.

\subsubsection{Bošavija}

\section{General information}

Name in English: Bošavija

Name in Macedonian: Bošavija (Бошавија)

IBA code: $\mathrm{MK} 027$

Criteria: A1

Area: 9,286 ha

Central coordinates: $22^{\circ} 06^{\prime} 53.53^{\prime \prime} \mathrm{E}, 41^{\circ} 16^{\prime} 16.92^{\prime \prime} \mathrm{N}$

Altitude: $377-1,280 \mathrm{~m}$ a.s.l.

Administrative region(s): Kavadarci, Demir Kapija

\section{Site description}

Starting at Stragovo village, the boundary of the site runs SW following the village road, until reaching the main road on the Vitačevo plateau (common border with the Tikveš Region site, MK013). It follows the road southwards (common border with the site Lake Tikveš, MK026) to the Čaškite locality, where it turns eastwards and runs through Prodanovec, crosses the Lisač River, the peak of Kumanova Glava (1,066 m a.s.l.) and the Bošava River, and by following the ravine north of Vasiljova Padina reaches the isohypse of 1,100 $\mathrm{m}$ at the Popranca locality. Then it follows the same isohypse to the Madžarsko Borče locality, crossing it and descending into the valley of the Dobošnica River. From here it follows the river downstream and north to the Dina locality, where it ascends to the Jurkov Rid locality and follows the ridge Gatenovo north to its peak (990 $\mathrm{m}$ a.s.l.). Here it turns west, descends through a ravine to the Bohulska Reka, following it to its confluence with the Bošava River. Then it turns SW following the Bošava to Krnjevo village, from where it follows the ridge NW to the village of Stragovo (Figure 47).

The valley of the Bošava River is dominant at the site, with the Vitačevo plateau in the western parts and slopes of Mt Kožuf in the south and east. Denudation forms are characteristic of the site, with different sand pillars and sand cliffs.

\section{Species}

This site was formerly part of the larger "Kožuf Mt and Bošava River” site (MK009, Heath \& Evans 2000), but the boundaries have been changed a great deal, as the importance of the rest of this site has not been confirmed with the surveys carried out in 2003 and 2004. The site has been relatively poorly studied; its importance was identified solely due to the presence of three breeding pairs of Egyptian Vultures in 2007 and at least three more before 1990 (B. GrubaČ

Table 71: List of triggering and other important bird species in the IBA Bošavija

Tabela 71: Seznam kvalifikacijskih in drugih pomembnih ptic IBA Bošavija

\begin{tabular}{lccccc}
\hline $\begin{array}{l}\text { Species/ } \\
\text { Vrsta }\end{array}$ & $\begin{array}{c}\text { Season/ } \\
\text { Sezona }\end{array}$ & $\begin{array}{c}\text { Year/ } \\
\text { Leto }\end{array}$ & $\begin{array}{c}\text { Population/ } \\
\text { Populacija }\end{array}$ & $\begin{array}{c}\text { Acc./ } \\
\text { Zan. }\end{array}$ & $\begin{array}{c}\text { Criteria/ } \\
\text { Kriteriji }\end{array}$ \\
\hline Neophron percnopterus & B & $\mathbf{2 0 0 7 - 2 0 1 0}$ & $\mathbf{I}-\mathbf{3}$ & A & A1 \\
Circaetus gallicus & $\mathrm{B}$ & 2007 & $2-3$ & $\mathrm{~B}$ & $\mathrm{~N}$ \\
Buteo rufinus & $\mathrm{R}$ & 2005 & 2 & $\mathrm{~B}$ & $\mathrm{~N}$ \\
Aquila chrysaetos & $\mathrm{R}$ & 2010 & $\mathrm{I}$ & $\mathrm{B}$ & $\mathrm{N}$ \\
Aquila pomarina & $\mathrm{B}$ & 2010 & $\mathrm{O}-\mathrm{I}$ & $\mathrm{B}$ & \\
\hline
\end{tabular}




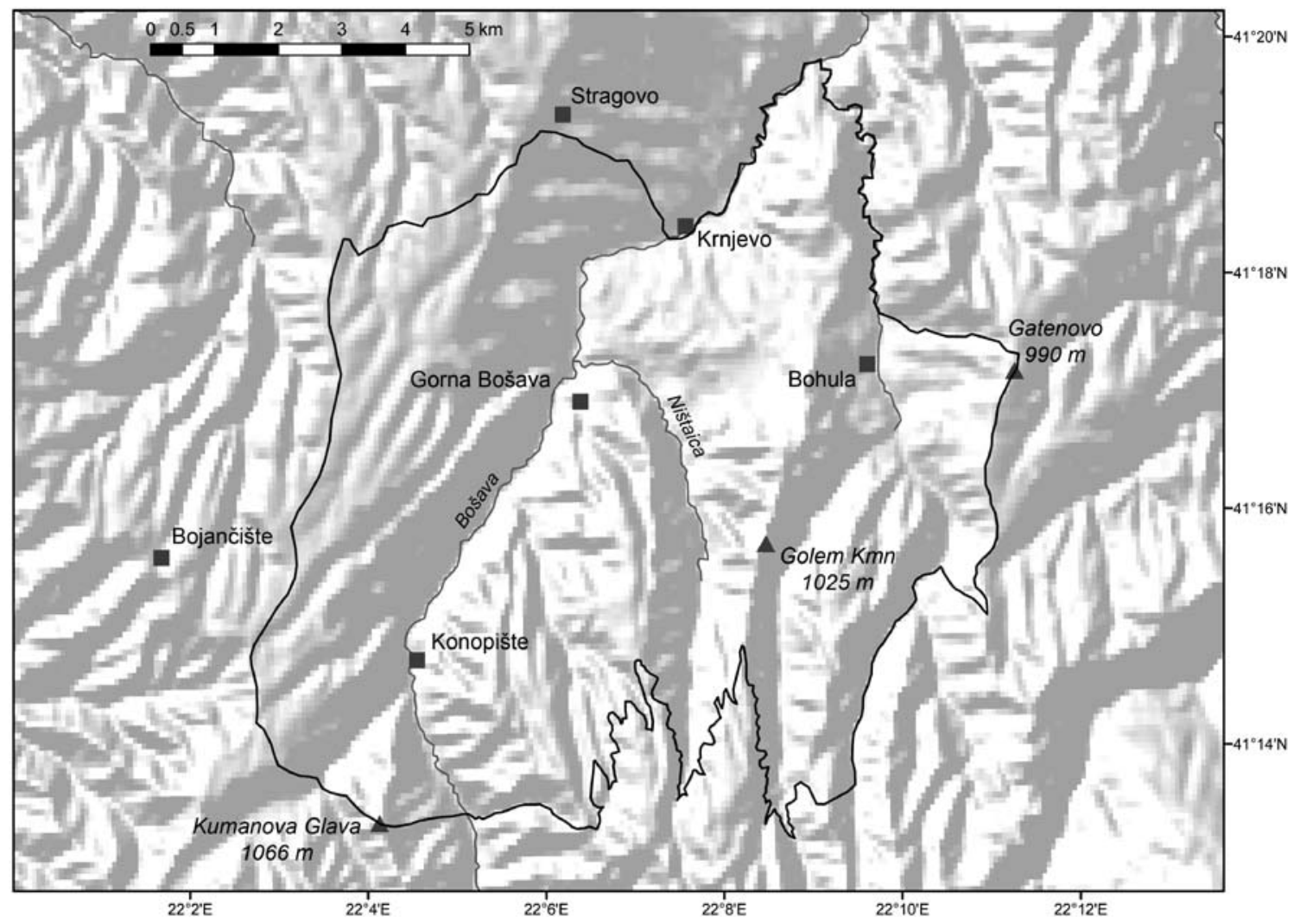

Figure 47: Map of the IBA Bošavija with its main features depicted

Slika 47: Zemljevid IBA Bošavija z glavnimi značinostmi območja

unpubl.). However, two of the pairs have been lost in the 2007-2008 period. Also, two pairs of Long-legged Buzzard and single pairs of Golden Eagle, Short-toed

Table 72: The main CORINE land cover types (Level 3) in the IBA Bošavija

Tabela 72: Glavni tipi pokrovnosti in rabe tal (po CORINE land cover, 3. nivo) v IBA Bošavija

\begin{tabular}{llc}
\hline $\begin{array}{l}\text { Code/ } \\
\text { Koda }\end{array}$ & $\begin{array}{l}\text { CORINE land cover type/ } \\
\text { tip pokrovnosti in rabe tal }\end{array}$ & $\begin{array}{c}\text { Coverage/ } \\
\text { Pokrovnost (\%) }\end{array}$ \\
\hline $2 \mathrm{II}$ & Non-irrigated arable land & 5.0 \\
$23 \mathrm{I}$ & Pastures & IO.9 \\
242 & Complex cultivation patterns & 4.5 \\
243 & Land principally occupied by & IO.4 \\
& $\begin{array}{l}\text { agriculture, with significant } \\
\text { areas of natural vegetation }\end{array}$ & \\
$3 \mathrm{II}$ & Broad-leaved forest & 36.0 \\
$32 \mathrm{I}$ & Natural grasslands & IO.8 \\
324 & Transitional woodland-shrub & 22.4 \\
\hline
\end{tabular}

Eagle and possibly Lesser Spotted Eagle have been confirmed breeding there (Table 71).

\section{Habitats and land use}

Oak and Beech Fagus sylvatica forests are dominant in the SE part of the site, while dry pastures prevail on the Vitačevo plateau. Agriculture is mosaic, mostly with small vineyards and gardens. Small sand cliffs are found along the Bošava River, forming suitable places for breeding of raptors (Table 72, Figure 48).

\section{Threats}

Poisoning in the wider surroundings, outside the IBA, has caused the loss of one, possibly both Egyptian Vulture pairs breeding at this site. Forestry activities impact the insufficiently studied oak and Beech forests, and hunting, possibly even poaching, takes place. New dangerous electricity poles have been recently erected. The area is being increasingly urbanized with weekend cottages, although permanent population is decreasing (Table 73). 
M. Velevski, B. Hallmann, B. Grubač, T. Lisičanec, E. Stoynov, E. Lisičanec, V. Avukatov, L. Božič \& B. Stumberger: Important Bird Areas in Macedonia: Sites of Global and European Importance

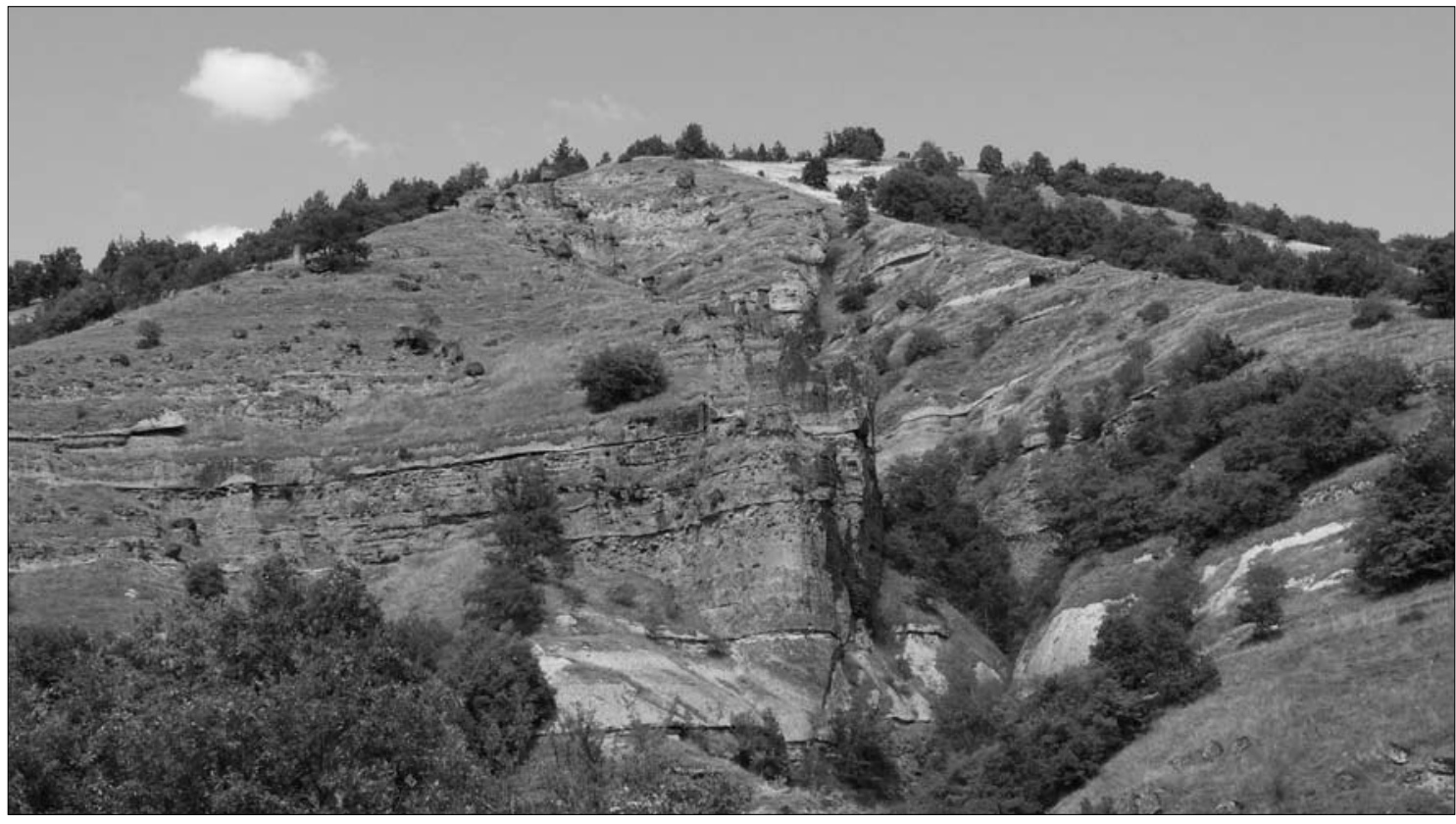

Figure 48: Characteristic landscape of the IBA Bošavija (photo: M. Velevski)

Slika 48: Značilna krajina IBA Bošavija (foto: M. Velevski)

Table 73: The main threats to birds and their importance in the IBA Bošavija

Tabela 73: Najpomembnejši dejavniki ogrožanja ptic in njihov vpliv v IBA Bošavija

\begin{tabular}{llll}
\hline $\begin{array}{l}\text { Code/ } \\
\text { Koda }\end{array}$ & \multicolumn{1}{c}{$\begin{array}{c}\text { Threat/ } \\
\text { Dejavnik ogrožanja }\end{array}$} & $\begin{array}{c}\text { Threat impact/ } \\
\text { Vpliv }\end{array}$ & \multicolumn{1}{c}{$\begin{array}{c}\text { Most affected species/ } \\
\text { Najbolj prizadete vrste }\end{array}$} \\
\hline I4I & Abandonment of pastoral systems & high & N.percnopterus \\
243 & Trapping, poisoning, poaching & high & N.percnopterus, A. chrysaetos \\
I60 & General forestry management & medium & A.pomarina \\
$5 \mathrm{II}$ & Electricity lines & medium & N.percnopterus \\
400 & Urbanised areas, human habitation & medium & A. chrysaetos \\
\hline
\end{tabular}

\section{Conservation}

A small protected area (Konopište) aimed at conserving the geomorphologic structures was designated. No active conservation measures are ongoing, and the rest of the site is not foreseen for any form of legal protection.

\subsubsection{Kočani Rice Fields}

\section{General information}

Name in English: Kočani Rice Fields

Name in Macedonian: Kočanski orizovi polinja (Кочански оризови полиња)

IBA code: $\mathrm{MK} 028$

\section{Criteria: B2}

Area: 11,192 ha

Central coordinates: 22¹9'39.76”E, 4152'38.18”N

Altitude: $280-400 \mathrm{~m}$ a.s.l.

Administrative region(s): Češinovo-Obleševo, Karbinci, Kočani, Probištip, Vinica, Zrnovci 


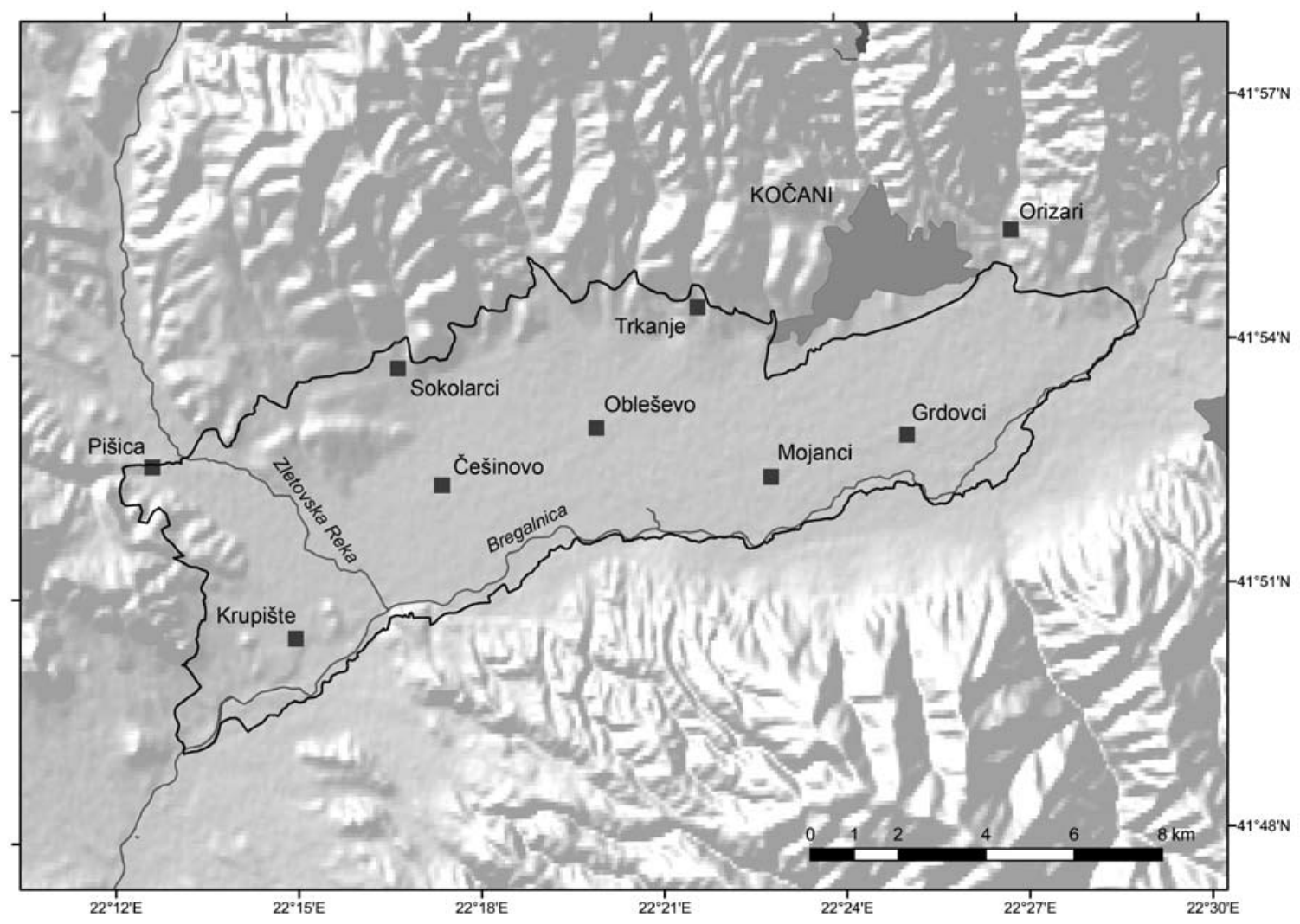

Figure 49: Map of the IBA Kočani Rice Fields with its main features depicted

Slika 49: Zemljevid IBA Kočanska riževa polja z glavnimi značilnostmi območja

\section{Site description}

Starting from the Bregalnica River west of Karbinci village, the site's boundary runs north for a short while following the railway, and then reaches the irrigation channel under the Rid locality (443 m a.s.l.). From here the site shares the boundary first with the IBA Ovče Pole (MK019) and then with the IBA Zletovska River Valley (MK012) right to the east of Sokolarci village. From here it continues eastwards to the village of Banja, follows the irrigation channel and via Preslop locality (393 m a.s.l.) reaches the village of Trkanje. Then it continues east along the channel to the stream of Belski Dol, follows it southwards to the Kočanska Reka River, and from here runs eastwards, first following the river, and then the road south of Kočani town, until reaching the Kočanska Reka again. From here it continues eastwards, following the local road to Toplički Rid, where it turns south and crosses

Table 74: List of triggering and other important bird species in the IBA Kočani Rice Fields

Tabela 74: Seznam kvalifikacijskih in drugih pomembnih vrst ptic v IBA Kočanska riževa polja

\begin{tabular}{lccccc}
\hline $\begin{array}{l}\text { Species/ } \\
\text { Vrsta }\end{array}$ & $\begin{array}{c}\text { Season/ } \\
\text { Sezona }\end{array}$ & $\begin{array}{c}\text { Year/ } \\
\text { Leto }\end{array}$ & $\begin{array}{c}\text { Population/ } \\
\text { Populacija }\end{array}$ & $\begin{array}{c}\text { Acc./ } \\
\text { Zan. }\end{array}$ & $\begin{array}{c}\text { Criteria/ } \\
\text { Kriteriji }\end{array}$ \\
\hline Ciconia ciconia & B & $\mathbf{2 0 1 I}$ & $\mathbf{1 5 0 - 1 8 0}$ & A & B2 \\
Ardea cinerea & B & 2009 & $50-70$ & B & N \\
Egretta garzetta & B & 2009 & IO-30 & C & N \\
Nycticorax nycticorax & B & 2009 & I0-30 & C & N \\
\hline
\end{tabular}


M. Velevski, B. Hallmann, B. Grubač, T. Lisičanec, E. Stoynov, E. Lisičanec, V. Avukatov, L. Božič \& B. Stumberger: Important Bird Areas in Macedonia: Sites of Global and European Importance

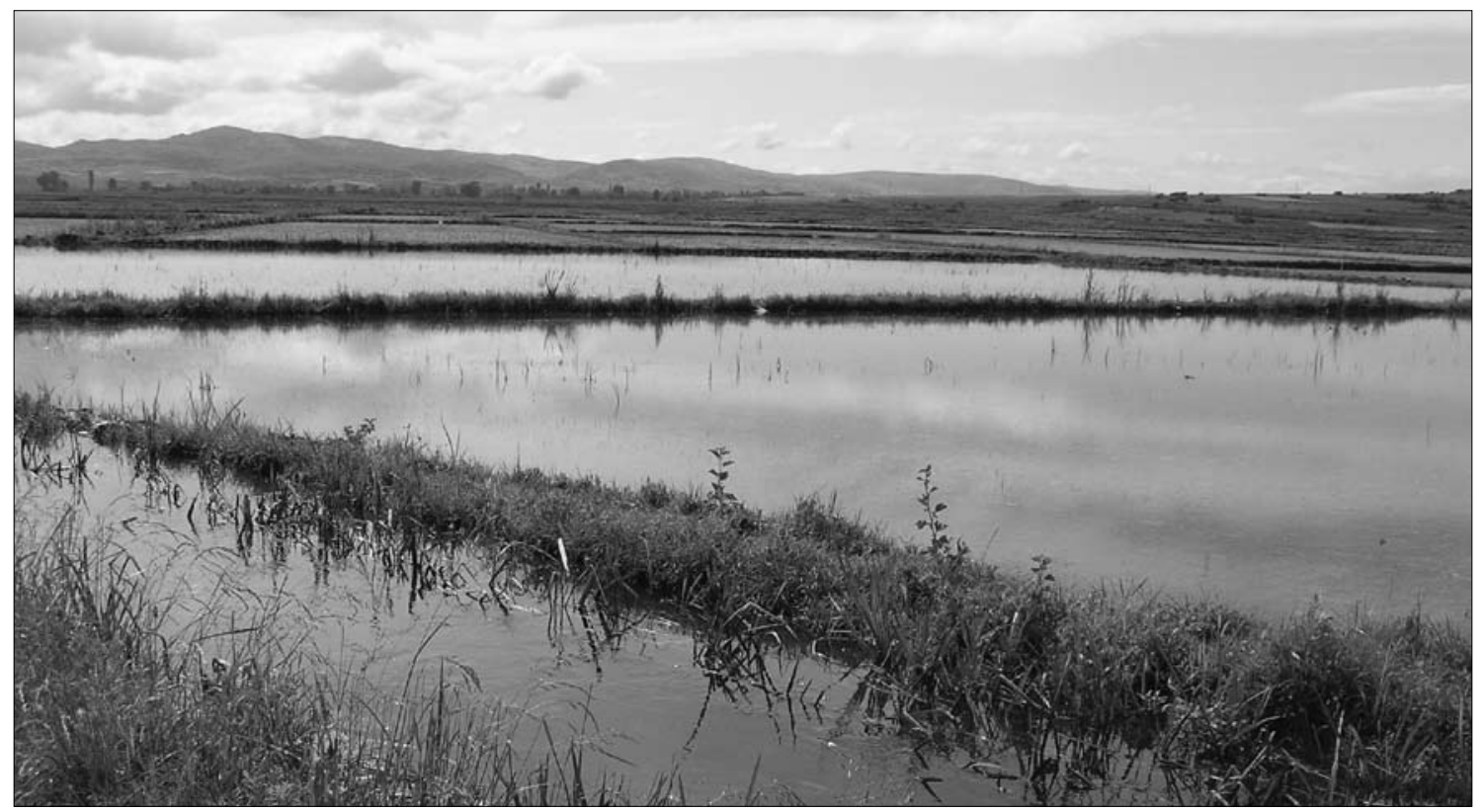

Figure 50: Characteristic landscape of the IBA Kočani Rice Fields (photo: G. Čamlík)

Slika 50: Značilna krajina IBA Kočanska riževa polja (foto: G. Čamlík)

Table 75: The main CORINE land cover types (Level 3) in the IBA Kočani rice fields

Tabela 75: Glavni tipi pokrovnosti in rabe tal (po CORINE land cover, 3. nivo) v IBA Kočanska riževa polja

\begin{tabular}{llc}
\hline $\begin{array}{l}\text { Code/ } \\
\text { Koda }\end{array}$ & $\begin{array}{l}\text { CORINE land cover type/ } \\
\text { tip pokrovnosti in rabe tal }\end{array}$ & $\begin{array}{c}\text { Coverage/ } \\
\text { Pokrovnost (\%) }\end{array}$ \\
\hline $2 \mathrm{II}$ & Non-irrigated arable land & 44.2 \\
$2 \mathrm{I} 3$ & Rice fields & 36.2 \\
242 & Complex cultivation patterns & IO.3 \\
243 & Land principally occupied by & $6 . \mathrm{I}$ \\
& agriculture, with significant & \\
& areas of natural vegetation & \\
324 & Transitional woodland-shrub & 34.0 \\
& Other & 3.2 \\
\hline
\end{tabular}

the Bregalnica River. Then it continues parallel to the river in SW and W directions, along small dirt roads or the riverbed, until reaching the starting point west of Karbinci village again.

The plain is a tectonic depression, with soils of alluvial origin, while on its northern edge delluvial soils are also found. Main rivers are the Bregalnica and its right tributary Zletovska Reka River (Figure 49).

\section{Species}

The bird fauna of this IBA is virtually unknown, without any published information.

Very large numbers of White Stork pairs (150-180) breed in the villages of this region (HECKENROTH \& HeINs in prep.), using its rice fields for foraging. Its breeding density is substantially larger than at Pelagonia

Table 76: The main threats to birds and their importance in the IBA Kočani Rice Fields

Tabela 76: Najpomembnejši dejavniki ogrožanja ptic in njihov vpliv v IBA Kočanska riževa polja

\begin{tabular}{llll}
\hline $\begin{array}{l}\text { Code/ } \\
\text { Koda }\end{array}$ & \multicolumn{1}{c}{$\begin{array}{c}\text { Threat/ } \\
\text { Dejavnik ogrožanja }\end{array}$} & $\begin{array}{c}\text { Threat impact/ } \\
\text { Vpliv }\end{array}$ & \multicolumn{1}{c}{$\begin{array}{c}\text { Most affected species/ } \\
\text { Najbolj prizadete vrste }\end{array}$} \\
\hline IIO & Use of pesticides & high & C. ciconia, E. garzetta, N. nycticorax, A. cinerea \\
IOI & Modification of cultivation practices & medium & $\begin{array}{l}\text { C. ciconia, E. garzetta, N. nycticorax, A. cinerea } \\
\text { SII }\end{array}$ \\
\hline
\end{tabular}


(the largest population in Macedonia), making the site of special importance for the conservation of the species. This site also holds the only known mixed colony of herons in Macedonia, consisting of Grey Herons, Night Herons and Little Egrets - for the latter, this is at present the only known breeding locality in Macedonia. Two more Grey Heron colonies are known within this site (Table 74). The importance of rice fields for breeding and migrating waterbirds is unknown, although presumably high.

\section{Habitats and land use}

The extensive rice fields give this site its characteristic image. They are usually flooded in May, and the water is retained there till August. Some of them periodically turn into other arable plots of land, thus creating mosaic landscape. Small patches of reedbeds are also found. The riparian forests with poplar and willow along the Bregalnica River are preserved in a narrow belt, presumably maintaining high biodiversity value (Table 75, Figure 50).

\section{Threats}

The threats are not sufficiently documented. Pesticide use is common during rice cultivation. Also, the number of ponds dried for the purpose of growing other crops (notably maize) seems to have been on increase in the last few years. Dangerous power poles are common in the region, very likely causing significant mortality of the storks (Table 76).

\section{Conservation}

No active conservation measures are ongoing, and the site is not foreseen for any legal protection.

\subsubsection{Lower Vardar}

\section{General information}

Name in English: Lower Vardar

Name in Macedonian: Dolen tek na reka Vardar (долен тек на река Вардар)

IBA code: MK029

Criteria: $\mathrm{B} 2$

Area: 5,357 ha

Central coordinates: $22^{\circ} 31^{\prime} 58.42^{\prime \prime} \mathrm{E}, 41^{\circ} 11^{\prime} 28.71^{\prime \prime} \mathrm{N}$

Altitude: $40-192 \mathrm{~m}$ a.s.l.

Administrative region(s): Bogdanci, Gevgelija, Valandovo

\section{Site description}

Starting from the right bank of the Vardar River along the Macedonian - Greek border, the site boundary

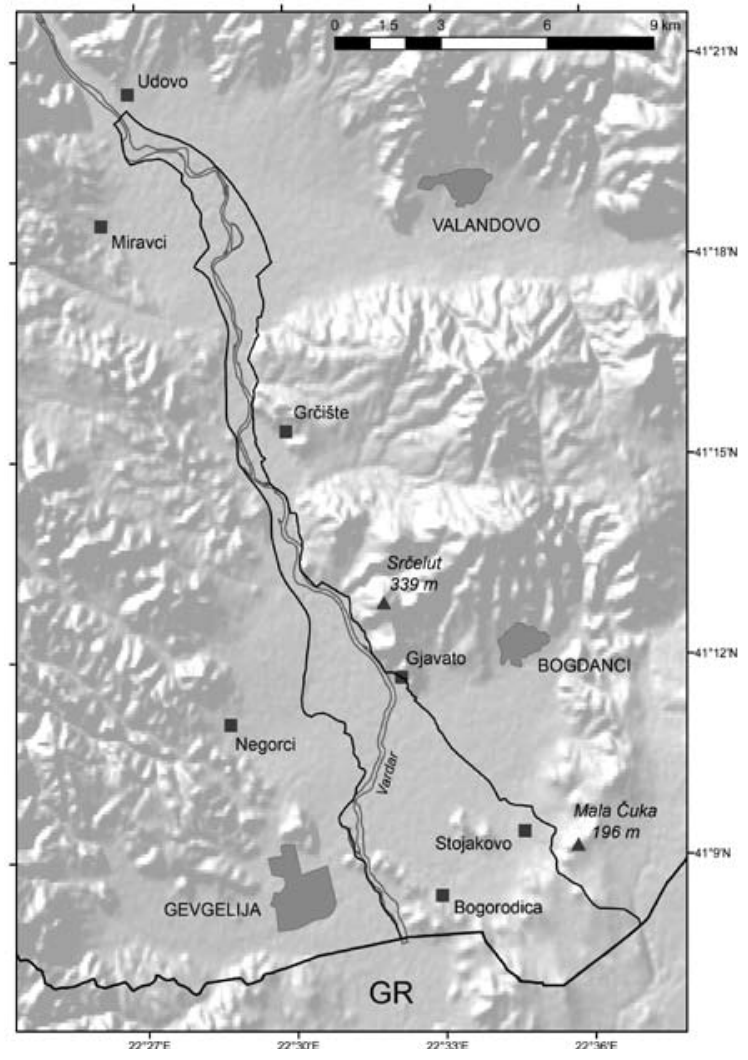

Figure 51: Map of the IBA Lower Vardar with its main features depicted

Slika 51: Zemljevid IBA Spodnji Vardar z glavnimi značilnostmi območja

follows the state border eastwards to 1 the Selemilska Reka stream, from where it turns NW and via Mala Čuka (196 m a.s.l.) descends towards the village of Stojakovo, including it into the site, and along a dirt road continues NW to include the village of Gjavato. From there it continues north, passing close to the left bank of the Vardar, leaving the greenhouses at Grčište village outside the site. Then it continues north along the local road till it reaches the E-75 Demir KapijaGevgelija motorway, passes through the Šopka and Lagovo localities until reaching the Anska Reka River, follows it east to the motorway, and then runs along it north to just south of Udovo village. The boundary crosses the Vardar at its confluence with the Selisste stream and turns south towards the railway station at Miravci village, passes through the Vrežot locality (66 $\mathrm{m}$ a.s.l.) along a dirt road and close to the Vardar River, continues south, crosses the Petruška Reka and reaches the railway. Then it follows the railway to the east of Negorci village, when it turns eastwards and 
M. Velevski, B. Hallmann, B. Grubač, T. Lisičanec, E. Stoynov, E. Lisičanec, V. Avukatov, L. Božič \& B. Stumberger: Important Bird Areas in Macedonia: Sites of Global and European Importance

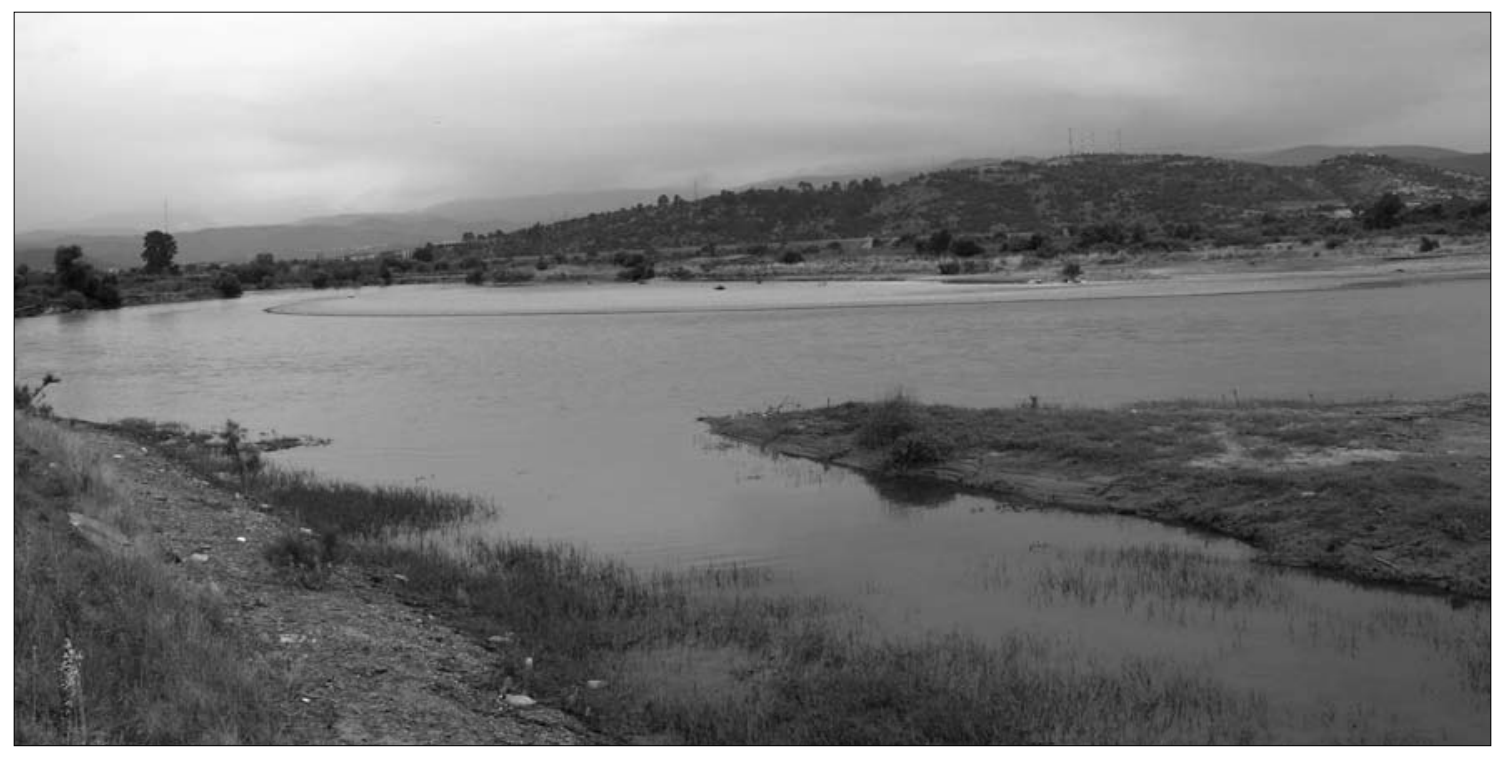

Figure 52: Characteristic landscape of the IBA Lower Vardar (photo: M. Velevski)

Slika 52: Značilna krajina IBA Spodnji Vardar (foto: M. Velevski)

Table 77: List of triggering and other important bird species in the IBA Lower Vardar

Tabela 77: Seznam kvalifikacijskih in drugih pomembnih vrst ptic v IBA Spodnji Vardar

\begin{tabular}{lccccc}
\hline $\begin{array}{l}\text { Species/ } \\
\text { Vrsta }\end{array}$ & Season/ & Year/ & Population/ & Acc./ & Criteria/ \\
Sezona & Leto & Populacija & Zan. & Kriteriji \\
\hline Ciconia ciconia & $\mathbf{B}$ & $\mathbf{2 0 I I}$ & $\mathbf{5 0 - 6 0}$ & $\mathbf{A}$ & $\mathbf{B 2}$ \\
Sternula albifrons & $\mathbf{B}$ & $\mathbf{2 0 0 9}$ & $\mathbf{1 5 - 3 0}$ & $\mathbf{B}$ & $\mathbf{B 2}$ \\
Riparia riparia & $\mathbf{B}$ & $\mathbf{2 0 1 0}$ & $\mathbf{8 0 0 - \mathbf { I } , \mathbf { 2 0 0 }}$ & $\mathbf{B}$ & $\mathbf{B 2}$ \\
Sterna hirundo & $\mathrm{B}$ & 2009 & $15-30$ & $\mathrm{~B}$ & $\mathrm{~N}$ \\
\hline
\end{tabular}

Table 78: The main CORINE land cover types (Level 3) in the IBA Lower Vardar

Tabela 78: Glavni tipi pokrovnosti in rabe tal (po CORINE land cover, 3. nivo) v IBA Spodnji Vardar

\begin{tabular}{llc}
\hline $\begin{array}{l}\text { Code/ } \\
\text { Koda }\end{array}$ & $\begin{array}{c}\text { CORINE land cover type/ } \\
\text { tip pokrovnosti in rabe tal }\end{array}$ & $\begin{array}{c}\text { Coverage/ } \\
\text { Pokrovnost (\%) }\end{array}$ \\
\hline 2 II & Non-irrigated arable land & I5.I \\
242 & Complex cultivation patterns & 46.7 \\
243 & Land principally occupied by & 4.3 \\
& agriculture, with significant & \\
& areas of natural vegetation & \\
$23 \mathrm{I}$ & Pastures & $\mathrm{I} 6.2$ \\
22I & Vineyards & 5.9 \\
$5 \mathrm{II}$ & Water courses & 5.7 \\
& Other & 6.0 \\
\hline
\end{tabular}

approaches the Vardar again. Close to its right bank, it reaches the state border again (Figure 51).

The Vardar riverbed between Udovo and Gevgelija is morphologically characterized by the monochannel's transition into a braided river type. This is the area with best-preserved natural river dynamics in Macedonia. The entire site is part of the Gevgelija-Valandovo valley, of tectonic origin. Alluvial deposits are found on both sides of the Vardar, but are most characteristic in western parts of the valley (the Miravci field). Aeolian sands are found in the vicinity of Gjavato village.

\section{Species}

The segment of the Vardar River near Gevgelija is important for a mixed colony ofCommon Sterna hirundo and Little Terns Sternula albifrons with at least 15 pairs of both species (ŠKORPíKOVÁ et al. 2009A) breeding on large 
Table 79: The main threats to birds and their importance in the IBA Lower Vardar

Table 79: Najpomembnejši dejavniki ogrožanja ptic in njhov vpliv v IBA Spodnji Vardar

\begin{tabular}{llll}
\hline $\begin{array}{l}\text { Code/ } \\
\text { Koda }\end{array}$ & \multicolumn{1}{c}{$\begin{array}{c}\text { Threat/ } \\
\text { Dejavnik ogrožanja }\end{array}$} & $\begin{array}{c}\text { Threat impact/ } \\
\text { Vpliv }\end{array}$ & \multicolumn{1}{c}{$\begin{array}{c}\text { Most affected species/ } \\
\text { Najbolj prizadete vrste }\end{array}$} \\
\hline 8IO & Drainage & high & C. ciconia \\
300 & Sand and gravel extraction & high & S. albifrons, S. hirundo, R. riparia \\
4IO & Industrial or commercial areas & high & $\begin{array}{l}\text { C. ciconia, S. albifrons, S. hirundo, R. riparia } \\
\text { 5II }\end{array}$ \\
\hline
\end{tabular}

gravel islets in the riverbed. Furthermore, at least two colonies (one of which is very large with $>800$ pairs) of Sand Martins Riparia riparia were found (M. VELEVSKI unpubl.). Truly spectacular passerine congregations during the migration period were also recorded (e.g. up to 2 million Barn Swallows Hirundo rustica in autumn along the Vardar River in September 1990, B. Stumberger unpubl.). Migration of soaring birds (raptors, storks) has not been studied, but is expected to be important, probably as a bottleneck site. Nearly $10 \%$ of the country's White Stork population breed within the IBA Lower Vardar. The large stork colonies in Stojakovo and Bogorodica villages held 28 and 21 breeding pairs in 2010, respectively (HECKENROTH \& Heins in prep.) (Table 77).

\section{Habitat and land use}

Remains of alluvial forests (e.g. willows, Oriental Plain Platanus orientalis), numerous gravel bars and sand river banks, reedbeds, and predominant mosaic agriculture in the lowlands on river deposits are the main features of this floodplain area. Tamarisk belts and shrublands are also well-preserved. Small hills are dominated by pastures, while some areas have been afforested with allochthonous tree species (Table 78, Figure 52).

\section{Threats}

A windfarm near the village of Miravci has already been approved. Gravel extraction takes place at several locations along the Vardar River. A large field near Bogorodica village was drained by channels. The existing dangerous power poles very likely cause mortalities in the White Stork population. The planned construction of a dam on the Vardar River just north of the site (at the village of Gradec) will probably change the entire water-regime downstream, altering sandbanks, gravel deposition and riparian vegetation. A pipeline is planned to pass through this region, and appropriate mitigation measures to conserve the floodplain will be needed (Table 79).

\section{Conservation}

No active conservation measures are ongoing, and the site is not foreseen for any legal protection.

\section{Discussion}

Three of the identified IBAs occupy the highest parts of the large mountain massifs, while three other IBAs embrace the large natural lakes. The rest are mostly located in the lower mountainous or hilly and especially lowland parts of the country, including breeding areas of species of global conservation concern. The percentage of territory covered by the IBAs in the country is relatively high, although less than Croatia with $40 \%$ of the land territory (RADović et al. 2005) and Spain with ca. 32\%, almost identical to Slovenia with 27\% (Denac et al. 20II), Greece with 26\% (Heath \& Evans 2000), and just slightly above Bulgaria with 23\%, (Kostadinova \& Gramatikov 2007). The fact that Macedonia has a much lower number of sites compared to these countries (Table 80), indicates their relatively large size. Indeed, almost the entire Pčinja - Vardar Valley, starting from the Serbian border in the north to Demir Kapija to the south, adjoined by Mariovo and Pelagonia, may be actually considered as one territory of clear importance for the conservation of species of the global conservation concern. This is largely due to the fact that IBA identification was possible primarily on the basis of occurrence of large raptors due to the precise quantitative data. As many of them have large home-ranges and some pairs even frequently change their breeding sites in consecutive breeding seasons, particularly the Imperial Eagle, inclusion of large areas in the network is justified. Compared to the other IBAs designated for the birds of prey in the Southern European region, the number of breeding pairs per area unit in Macedonia is well within the range.

This IBA network includes significant portion of the national population of the species of global conservation concern. Specifically, about $80-90 \%$ of 
M. Velevski, B. Hallmann, B. Grubač, T. Lisičanec, E. Stoynov, E. Lisičanec, V. Avukatov, L. Božič \& B. Stumberger: Important Bird Areas in Macedonia: Sites of Global and European Importance

Table 80: Comparison of number of IBAs and their total coverage among countries of Southern Europe and its surroundings

Tabela 80: Primerjava med števili IBA-jev v državah južne Evrope z okolico in skupna površina IBA-jev v posameznih državah

\begin{tabular}{|c|c|c|c|c|}
\hline $\begin{array}{l}\text { Country/ } \\
\text { Država }\end{array}$ & $\begin{array}{c}\text { Country size/ } \\
\text { Velikost države }\left(\mathrm{km}^{2}\right)\end{array}$ & $\begin{array}{l}\text { Total IBA coverage/ } \\
\text { Skupna površina } \\
\text { IBA-jev }\left(\mathrm{km}^{2}\right)\end{array}$ & $\begin{array}{c}\text { Percentage of territory } \\
\text { under IBA/ } \\
\text { Odstotek ozemlja v } \\
\text { okviru IBA (\%) }\end{array}$ & $\begin{array}{l}\text { Total no. of IBAs/ } \\
\text { Skupno št. IBA-jev }\end{array}$ \\
\hline Albania & 28,750 & 903 & 3 & Is \\
\hline Armenia & 29,800 & $\mathrm{I}, 820$ & 6 & 5 \\
\hline Azerbaijan & 86,600 & 6,I6I & 7 & 52 \\
\hline Bosnia & $5 \mathrm{I}, \mathrm{I} 30$ & 68 & $<\mathrm{I}$ & 3 \\
\hline Bulgaria & IIо,994 & 26,021 & 23 & II 4 \\
\hline Croatia & 56,540 & $22,654^{*}$ & $40^{*}$ & 40 \\
\hline Cyprus & 9,250 & $\mathrm{I}, 305$ & I4 & I6 \\
\hline France & 551,600 & 47,248 & 9 & 277 \\
\hline Greece & 132,000 & 34,332 & 26 & 196 \\
\hline Hungary & 93,032 & 14,662 & 16 & 43 \\
\hline Italy & 301,302 & 46,270 & 15 & 192 \\
\hline Macedonia & 25,713 & 6,907 & 27 & 24 \\
\hline Moldova & 33,700 & 509 & 2 & $\mathrm{I} 2$ \\
\hline Portugal & 89,000 & $9,42 \mathrm{I}$ & II & 34 \\
\hline Romania & 237,500 & 6,557 & 3 & 44 \\
\hline Serbia & $88,36 \mathrm{I}$ & I2,596 & I4 & 35 \\
\hline Slovenia & 20,272 & 5,538 & 27 & 35 \\
\hline Spain & 492,463 & 157,689 & 32 & $39 \mathrm{I}$ \\
\hline Turkey & 779,452 & 29,978 & 4 & 97 \\
\hline Ukraine & 603,700 & 20,323 & 3 & IO2 \\
\hline
\end{tabular}

Croatia after Radović et al. (2005), Bulgaria after Kostadinova \& Gramatikov (2007), Serbia after Puzović et al. (2009), and Slovenia after Denac et al. (20II), all other countries after HEATH \& EVANS (2000)

* only land IBAs (marine sites excluded)

the national Imperial Eagle breeding population, all but one known pair ( $95 \%$ of the national population) of Egyptian Vultures, all known possibly breeding pairs of the Saker Falcon, all non-breeding and wintering individuals of Dalmatian Pelican, $40-75 \%$ of the Ferruginous Duck population and at least $40-50 \%$ of the Roller population are included in the IBA network. With regard to the species of European importance, $80-100 \%$ of all Lesser Kestrel pairs, $50-60 \%$ of the Long-legged Buzzard, ca. $50 \%$ of the Lanner Falcon breeding population, $45-55 \%$ of the Short-toed Eagle, $40-50 \%$ of the Golden Eagle, 30$50 \%$ of the Eagle Owl, 35-45\% of the Black Stork, $25-50 \%$ of the Peregrine Falcon and ca. $20-25 \%$ of the Levant Sparrowhawk populations of are included. Furthermore, all known breeding pairs and main foraging areas of the Griffon Vultures are also covered by the network. The network is also representative of the species characteristic of the Eurasian high-montane biome and the Mediterranean biome (except for the
Sardinian Warbles Sylvia melanocephala) (Appendix 5).

A large gap exists in the knowledge regarding the population sizes of many species, especially passerines, and priority for further research should be placed on the species that presumably meet the $0.5 \%$ threshold of the European populations, for which there is not enough information available at the moment to support site-based conservation approach (Appendix 1). These are mainly species occupying a variety of habitats and widely distributed throughout the country. Also, for a few species for which site-based conservation approach is considered suitable, lack of quantitative data prevented us from identifying the best sites. Of highest importance are efforts to precisely estimate the breeding population of the globally Near Threatened Semicollared Flycatcher, as breeding records exists from the northernmost (ŠKORPíKOVÁ et al. 2009B) to the southernmost (HöLzINGer 1987) parts of the country. 
There are still gaps in knowledge on the distribution and population estimates for several important species, and improving of this situation may result in identification of additional IBAs. The Sardinian Warbler (triggering species under the $\mathrm{A} 3$ criterion as a part of the Mediterranean biome species assemblage) is evidently underrepresented in the network, although no less than eight sites were identified that hold significant numbers of different species characteristic of the Mediterranean biome. This species, opposite to other species of this assemblage, is found in Macedonia almost exclusively in the pseudomaquis in the southernmost part of the country (roughly the triangle between Demir Kapija, Gevgelija and Lake Dojran), and some part of the population may be included in the Demir Kapija Gorge site (MK008), although no firm data exist. However, further survey of this region aimed at this species is needed to delineate additional IBA, which would ideally also include potentially important populations of some other more or less underrepresented species, e.g. Levant Sparrowhawk, Booted Eagle, Lesser Spotted Eagle and some other Mediterranean species. Parts of the Skopje Valley might hold important White Stork numbers (the population has increased since the work published by MicevsKi et al. 1992), and also possibly important population of the Roller, as at some places along the Vardar River its density of 1.5 pairs $/ \mathrm{km}^{2}$ has been noted (M. VeleVsKI unpubl.). The surroundings of Monospitovo Marsh near Strumica also hold important population of White Stork (ca. 60 pairs, Heckenroth \& Heins in prep.), but at present no other species that might support IBA identification in this area are known.

Some of the mountains in western Macedonia, notably Mt Stogovo, may also meet A3 criterion for the species characteristic of the Eurasian high-montane biome. So far, only the Alpine Chough and the Snow Finch have been recorded, although the presence of Wallcreeper and Alpine Accentor is very likely. However, if relative abundance or population sizes are proved to be lower than at the other three sites already identified, we consider identification of additional IBA for this species assemblage not justified. The Matka Canyon near Skopje holds one pair of Egyptian Vultures and several other species characteristic of the Mediterranean biome (A3 criterion), while one species, the Eagle Owl, possibly meets B2 criterion, even though the site has not been proposed as an IBA (VeleVsKi 2008).

Abandonment of pastoral system, resulting in decrease of the livestock numbers (overview in VELEVSKI et al. 2003), and overgrowing of the pastures have been identified as one of the most serious threats at 11 sites. It most negatively impacts the vultures (most notably Griffon Vulture at the national level) and other facultative necrophagous species such as the Imperial and Golden Eagles. Habitat loss due to overgrowing of the pastures negatively affects species that use this habitat for foraging (notably Lesser Kestrel in the lowlands and Alpine Chough in the mountains) or breeding (Stone Curlew). Equally important threat, also with estimated high impact at 11 sites, are direct losses from poaching and poisoning resulting in dramatic decrease in the number of vultures and, very likely, Imperial Eagles.

Interspecific faunal relationships, particularly reduction of the natural prey base due to habitat changes, overhunting and poaching (notably the European Hare Lepus europeus, Roe Deer Capreolus capreolus and Alpine Chamois Rupicapra rupicapra), but since recently also overharvesting of tortoises (Testudo hermanni and T. graeca) are likely having a negative impact on raptors and possibly scavengers that are exposed to the additional risk of secondary lead poisoning.

About $21 \%$ of the identified IBAs overlap the national protected area network (Melovski et al. in prep.). Notably underrepresented are regions in the lower parts of the country, which means that the populations of Imperial Eagle, Lesser Kestrel, Roller and to some degree Egyptian Vulture inhabit the areas outside the boundaries of the existing protected areas. The situation is somewhat better with the mountainous IBAs and particularly the natural lakes. However, management measures oriented towards bird conservation are rarely a practice. High coverage of agricultural areas on the IBAs (totalling almost half of the entire surface area) suggests that promotion of new protected areas is likely to be difficult, and conservation measures will be highly dependent on suitable implementation of agri-environmental schemes in the country.

Acknowledgements: Most of the data on the birds of prey used in this work were collected in the 20032010 period, during field work carried out within the framework of the Vulture Conservation Project in Macedonia, financed by the Frankfurt Zoological Society (FZS) (Germany), Black Vulture Conservation Foundation (BVCF) and Vulture Conservation Foundation (VCF). Significant contribution during the field work was provided by Bobi Delov, Mladen Pop Trajkov, Jovan Andevski, Elizabeta Dimitrovska, Marjan Manoilov and Kostadin Kočov. Vlasta Škorpíková and Václav Prášek (Czech Ornithological Society) also made available their field data from 
M. Velevski, B. Hallmann, B. Grubač, T. Lisičanec, E. Stoynov, E. Lisičanec, V. Avukatov, L. Božič \& B. Stumberger: Important Bird Areas in Macedonia: Sites of Global and European Importance

Macedonia, some of them having been used for more precise estimation of the populations of certain species. Hartmut Heckenroth and Jens-Uwe Heins (The Stork Foundation) kindly made available their unpublished data from the White Stork census. Macedonian Ecological Society (MES) allocated significant resources to support the work on the data collection, analyses and presentation. Aleksandar Sarov (MES) provided valuable help with the GIS software. Biology Students' Research Society made possible for the first author surveys in several mountains in Macedonia. Dr Dragan Kolčakovski offered assistance during description of the geology, geomorphology and hydrography of the sites. Ministry of Environment and Physical Planning of Republic of Macedonia made available the Emerald database to the MES, from where the threat codes and digital boundaries of the Emerald sites became available. Dr Ian Burfield (BirdLife International) made available the original fact sheets (with boundaries) of the first pan-European IBA inventory that were used as a foundation for the identification of the new IBAs, provided valuable guidance and suggestions during the entire process of identification of the IBAs. Wetlands International made available to the MES all historical data for the mid-winter counts in Macedonia. The Ministry of Agriculture, Nature Management and Fisheries of the Netherlands supported the Imperial Eagle work of Ben Hallmann. Club 300 Foundation, Sweden, supported FWFF - Bulgaria and "Aquila" NCA work on the Lesser Kestrel and Imperial Eagle, while the Fund for Wild Flora and Fauna - Bulgaria supported the Imperial Eagle, Lesser Kestrel and vultures censuses in the 2000-2003 period. Parts of the expenses for the fieldwork, carried out by the MES during 2010 and 2011, and the time dedicated to this work by the first author were made possible within the project "Wings Across the Balkans: Preparing countries in the Western Balkans for implementing the EU Birds Directive", led by BirdLife International (European Division) and financed by the assistance of the European Union, from the pre-accession funds - Instrument of Preaccession (IPA), as part of the "Partner activities" programme IPA Civil Society Facility. Earlier draft of the manuscript was kindly improved by Vlasta Škorpíková and Dr Slavčo Hristovski. Photographs were kindly provided by: Žarko Brajanoski, Gašpar Čamlík, Dr Slavčo Hristovski, Dr Ljupco Melovski and Borut Rubinić.

\section{Povzetek (SI) / Резиме (MK)}

Opredeljevanje Mednarodno pomembnih območij za ptice (IBA) je pobuda, ki jo organizacija BirdLife International izvaja na svetovni ravni, njen glavni namen pa je zavarovati mrežo območij, ki so še posebej pomembna za ohranitev ptic. $S$ spremenjenim naravovarstvenim statusom nekaterih ptic in $\mathrm{z}$ naraščajočim številom podatkov o razširjenosti in velikosti ptičjih populacij v Makedoniji na splošno je bila potrebna temeljita revizija omrežja IBA za posodobitev popisov, objavljenih v letih 1989 in 2000. Glede na dejstvo, da je ptičja favna Republike Makedonije med najslabše poznanimi v Evropi in še vedno ni na voljo podatkov o mnogih pticah, predvsem pevcih, je popis slonel predvsem na nekaterih ogroženih ali redkih ujedah in še nekaterih večjih pticah, značilnih za makedonsko krajino. Uporabljeni podatki so bili zbrani v obdobju različnih poglobljenih študij in projektov, opravljenih po letu 2000. Od 314 vrst, doslej zabeleženih $\mathrm{v}$ Makedoniji, 114 redno pojavljajočih se vrst trenutno obravnavamo kot vrste $\mathrm{z}$ neugodnim varstvenim statusom $\mathrm{v}$ Evropi, 84 od katerih gnezdi ali domnevno gnezdi v Makedoniji. Za izbor globalno (kriterij A) in evropsko pomembnih (kriterij B) IBA-jev je bilo uporabljenih več kriterijev, ki jih je razvil BirdLife International, pri čemer so bile upoštevane vrste globalne varstvene pozornosti (A1), vrste, strogo vezane ne različne biome (A3), pomembne zgostitve ptic (A4, B1), vrste z neugodnim varstvenim statusom (B2) in vrste, koncentrirane v Evropi (B3). Vrste globalne varstvene pozornosti, uporabljene za določitev območij, vključujejo egiptovskega jastreba Neophron percnopterus, ki je glede na najnovejši Rdeči seznam ogroženih vrst (kategorizacija IUCN Svetovne zveze za varstvo narave) ogrožen (mednarodna oznaka EN) na svetovni ravni, kodrastega pelikana Pelecanus crispus in kraljevega orla Aquila heliaca (oba ranljiva - VU) ter zlatovranko Coracias garrulus in balkanskega muharja Ficedula semitorquata (oba blizu ogroženosti - NT). Poleg tega so bile v Makedoniji zabeležene skupine vrst, za katere je značilno, da se pojavljajo večinoma ali v celoti znotraj evrazijskega visokogorskega ali mediteranskega bioma. Pomembne zgostitve negnezdečih vodnih ptic z najmanj $1 \%$ globalnih ali biogeografskih populacij posameznih vrst se pojavljajo na vseh treh velikih makedonskih jezerih, nekatere izmed njih (kot na primer kodrasti pelikan in tatarska žvižgavka Netta rufina) celo v zelo velikem številu, tako da presegajo 1-odstotno raven za več kot desetkrat. Za izbor evropsko pomembnih območij je bilo skupaj uporabljenih 25 vrst, ki se tu redno pojavljajo $v$ gnezditveni sezoni in za katere je območno 
varstvo v Makedoniji ustrezno. Meje posameznih območij so bile zarisane glede na izrazite fizične značilnosti območja ali izohipse, da so lahko zaobjele gnezdišča in prehranjevališča kvalifikacijskih vrst, kar zadeva kraljevega orla in egiptovskega jastreba, pa tudi njuna nekdanja gnezdišča do leta 1991, pri čemer so bila upoštevane habitatne zahteve ptic, raba tal in različne upravljalske potrebe. Seznam IBA-jev, ki je nastal na tej osnovi, vsebuje 24 območij, ki pokrivajo $6.907 \mathrm{~km}^{2}$ ali 26,9 \% celotnega makedonskega ozemlja: (1) Šar Planina, (2) Povodje reke Radike, (3) Ohridsko jezero, (4) Prespansko jezero, (5) Soteska Demir Kapija, (6) Dojransko jezero, (7) Dolina Zletovske reke, (8) Tikveško okrožje, (9) Reke Pčinja - Petrošnica - Kriva reka, (10) Preod - Gjugjance, (11) Osogovsko gorovje, (12) Gora Jakupica, (13) Soteska Taor, (14) Ovče Pole, (15) Reke Topolka - Babuna - Bregalnica, (16) Gradsko - Rosoman - Negotino, (17) Jezero Mantovo in reka Kriva Lakavica, (18) Dolina reke Raec, (19) Pelagonija, (20) Mariovo, (21) Tikveško jezero, (22) Bošavija, (23) Kočanska riževa polja, in (24) Spodnji Vardar. Z izjemo treh območij, ki pokrivajo najvišje vrhove velikih gorskih masivov $\mathrm{v}$ SZ in osrednjih delih Makedonije, kot tudi Ohridskega in Prespansko jezera so območja koncentrirana predvsem $\mathrm{v}$ osrednjih hribovskih in nižinskih delih Makedonije in zaobjemajo gnezditvena območja vrst globalne varstvene pozornosti. Odstotek ozemlja, ki ga pokrivajo IBA-ji v Makedoniji, je razmeroma visok $\mathrm{v}$ primerjavi s celotnim evropskim povprečjem, vendar primerljiv z več državami v JV delu Evrope. Velikost posameznih IBA-jev je med $25 \mathrm{~km}^{2}$ (Soteska Taor) in $1.136 \mathrm{~km}^{2}$ (Pelagonija), število kvalifikacijskih vrst na območje pa med ena (Bošavija, Kočanska riževa polja) in 17 (Reke Pčinja - Petrošnica - Kriva reka). 22 območij ustreza nekaterim kriterijem za globalno pomembne IBA-je - tri območja (Ohridsko, Prespansko in Dojransko jezero) kriteriju A4, v osmih gnezdijo pomembne populacije vrst, značilnih za mediteranski biom, medtem ko na treh območjih prebivajo pomembne populacije vrst, značilnih za evrazijski visokogorski biom. Vrste globalne varstvene pozornosti se pojavljajo $v$ različnem številu območij, in sicer: egiptovski jastreb $\mathrm{v}$ trinajstih, kraljevi orel $\mathrm{v}$ sedmih, kodrasti pelikan in sokol plenilec Falco cherrug $\mathrm{v}$ dveh, kostanjevka Aythya nyroca v treh, zlatovranka v desetih, rdečenoga postovka Falco vespertinus v treh in balkanski muhar v enem. Posamezne kvalifikacijske vrste za evropsko pomembna območja so zastopane v 2-15 območjih. Omrežje IBA-jev vključuje 80-100 $\%$ nacionalnih populacij globalno ogroženih vrst, medtem ko se zastopanost drugih vrst giblje med 5 in $100 \%$, vendar prek $40 \%$ za veliko večino vrst.
Opuščanje tradicionalnega pastirstva, ki se kaže v zmanjševanju živinskih čred in posledično zaraščanju ter lov s pastmi, zastrupljanje in divji lov sta med najpomembnejšimi dejavniki ogrožanja kvalifikacijskih vrst, še posebno za egiptovskega jastreba in kraljevega orla, saj je bil njun vpliv opredeljen kot velik na nič manj kot enajstih območjih. Nacionalna pravna zaščita območij je vse prej kot popolna, saj je bodisi samo delna ali $\mathrm{z}$ neustreznimi varstvenimi ukrepi, ali pa $\mathrm{v}$ mnogih območjih kakršne koli pravne zaščite sploh ni. Glede na dejstvo, da se samo $21 \%$ zavarovanih območij prekriva z IBA-ji, je obstoječi sistem torej neustrezen za varovanje večine prednostnih vrst. To še posebno velja za območja $v$ nižje ležečih delih države $z$ največjim številom vrst globalne varstvene pozornosti.

\section{$* * *$}

Идентификацијата на Значајните подрачја за птици (ЗПП) (Important Bird Areas, IBAs) е иницијатива спроведувана од BirdLife International на глобално ниво, со цел да се заштити мрежа на подрачја кои се од особено значење за зачувување на птиците. Со промената на конзервацискиот статус на некои видови, и воопшто со новите податоци за распространувањето и големините на популациите на птиците во Македонија, беше потребна ревизија на мрежата на ЗПП за да се ажурираат постојните информации за подрачјата во земјата, објавени во 1989 и 2000 година. Бидејќи фауната на птиците во Република Македонија е меѓу најмалку проучените во Европа, и бидејќи сѐ уште во голема мера недостигаат податоци за многу видови, посебно птици-пејачки, инвентаризацијата главно е направена врз основа на податоците за некои засегнати или ретки грабливи птици и неколку други покрупни видови, карактеристични за македонските предели. Користените податоци беа собирани во текот на различни студии и проекти, реализирани по 2000 година. Од 314 видови птици регистрирани во Македонија до денес, 114 редовно присутни видови во моментов имаат неповолен конзервациски статус во Европа, а од нив 84 гнездат или веројатно гнездат во Македонија. При селекцијата на подрачјата беа користени неколку критериуми развиени од BirdLife International за избор на ЗПП од глобално (критериум А) и европско (критериум В) значење, земајќи ги предвид видовите од глобален интерес за зачувување (A1), видовите ограничени на посебни биоми (А3), значајните собиралишта (A4, B1) и видови со неповолен конзервациски статус (В2) или концентрирани во Европа (B3). Видовите од глобален интерес за зачувување ги вклучуваат египетскиот мршојадец (Neophron percnopterus), кој се смета за загрозен (EN) на глобално ниво според најновата црвена листа на IUCN на засегнати видови, кадроглавиот пеликан (Pelecanus crispus) и царскиот орел (Aquila heliaca) (двата чувствителни - VU) и модровраната (Coracias garrulus) и шареното муварче (Ficedula semitorquata) (близу засегнати - NT). Понатаму, во Македонија 
M. Velevski, B. Hallmann, B. Grubač, T. Lisičanec, E. Stoynov, E. Lisičanec, V. Avukatov, L. Božıč \& B. Stumberger: Important Bird Areas in Macedonia: Sites of Global and European Importance

се среќаваат и групи на видови карактеристични за европскиот високопланински или медитеранскиот биом. Трите големи природни езера се значајни собиралишта на негнездечки водни видови птици, кои сочинуваат најмалку $1 \%$ од биогеографската популација на одделниот вид, од кои некои (на пр., кадроглавиот пеликан, патката превез (Netta rufina)) во многу голем број, повеќе од десеткратно надминувајќи го прагот од $1 \%$. За селекција на подрачјата од европско значење беа користени вкупно 25 видови кои редовно се присутни во Македонија, а за кои пристапот на зачувување преку заштита на подрачја се смета за соодветен. Границите на подрачјата беа нацртани следејќи изразени географски карактеристики или изохипси, за да ги вклучуваат местата на гнездење и исхрана на видовите кои ги исполнуваат критериумите, за царскиот орел и египетскиот мршојадец и поранешните места на гнездење (по 1991), земајќи ги предвид нивните потреби од живеалишта, користење на земјиштето и потребите од управување. Резултатот вклучува 24 ЗПП, покривајќи $6907 \mathrm{~km}^{2}$ или 26,9\% од површината на Македонија: (1) Шар Планина, (2) Сливот на реката Радика, (3) Охридско Езеро, (4) Преспанско Езеро, (5) Демиркаписка Клисура, (6) Дојранско Езеро, (7) Долината на Злетовска Река, (8) Тиквешкиот регион, (9) Реката Пчиња - реката Петрошница - Крива Река, (10) Преод - Ѓуѓанце, (11) Осоговски Планини, (12) Јакупица, (13) Таорска Клисура, (14) Овче Поле, (15) Реката Тополка - реката Бабуна - реката Брегалница, (16) Градско - Росоман - Неготино, (17) Мантовскот Езерто и реката Крива Лакавица, (18) Долината на реката Раец, (19) Пелагонија, (20) Мариово, (21) Тиквешко Езеро, (22) Бошавија, (23) Кочански оризови полиња и (24) Долниот тек на реката Вардар. Со исклучок на трите подрачја кои ги зафаќаат планинските масиви во северозападните и централните делови на Македонија, и Охридското и Преспанското Езеро, подрачјата се концентрирани главно во централните ридести и низински делови на земјата, опфаќајќи подрачја со гнезда на глобално засегнати видови. Процентот на територија покриена со ЗПП во Македонија е релативно висок споредено со вкупниот европски просек, но е споредлив со неколку земји во југоисточна Европа. Површината на поодделни ЗПП се движи од $25 \mathrm{~km}^{2}$ (Таорска Клисура) до $1136 \mathrm{~km}^{2}$ (Пелагонија), а бројот на видови кои ги исполнуваат критериумите од еден (Бошавија, Кочански оризови полиња) до 17 (Река Пчиња - река Петрошница - Крива Река). 22 подрачја исполнуваат некои од критериумите за подрачја од глобално значење, три подрачја (Охридското, Преспанското и Дојранското Езеро) го исполнуваат критериумот А4, осум подрачја поддржуваат значаен дел од популациите на видови карактеристични за медитеранскиот биом, а три други подрачја поддржуваат значаен дел од популациите на видови карактеристични за европскиот високопланински биом. Видовите од глобален интерес за зачувување се вклучени во мрежата на ЗПП на следниот начин: египетскиот мршојадец на 13 подрачја, царскиот орел на седум, кадроглавиот пеликан и ловџискиот сокол (Falco cherrug) на две, црниот кожувар (Aythya nyroca) на три, модровраната на
10, црвеноногата ветрушка (Falco vespertinus) на три и шареното муварче на едно подрачје. Поединечни видови кои ги исполнуваат критериумите за подрачја од европско значење се присутни на од 2 до 15 подрачја. Мрежата на ЗПП вклучува 80-100\% од националните популации на глобално засегнатите видови, а вклученоста на останатите видови варира од 5 до 100\%, при што за голем дел од видовите е над $40 \%$. Ненаводнуваните обработливи површини и преодните шумски честаци се доминантни типови на покровност на земјиштето, заедно покривајќи $32 \%$ од вкупната површина на ЗПП. Напуштањето на традиционалниот сточарски систем што резултира со намалување на бројот на сточниот фонд и зараснување на пасиштата, како и поставувањето стапици, труењето и криволовот, се сметаат за најсериозни закани за видовите кои ги исполнуваат критериумите, особено за египетскиот мршојадец и царскиот орел, и се класифицирани како „високи“ на не помалку од 11 подрачја. Националната заштита на подрачјата е недоволна, реализирајќи се или делумно, или без соодветни мерки на заштита кои ce во сила, а многу подрачја сѐ уште немаат никаква форма на законска заштита. Со $21 \%$ од националната мрежа на заштитени подрачја која се преклопува со ЗПП, постојниот систем на заштитени подрачја е недоволен за зачувување на најприоритетните видови. Особено постои празнина кај регионите во ниските делови на земјата, кои се со највисок број на видови од глобален интерес за зачувување.

\section{References}

Apostolski, K. \& Matvejev, S. (I955): Lov riba u ogradama pomoću ptca na Dojranskom jezeru. - Izdanija Zavod za ribarstvo na NR Makedonija 1 (3): 29-65.

Birdlife InTERnATIONAL (2004): Birds in Europe: population estimates, trends and conservation status. BirdLife Conservation Series No. 12. - BirdLife International, Cambridge.

Birdife International (20II): Species factsheet: Lesser Kestrel Falco naumanni. - [http://www.birdlife.org/ datazone/speciesfactsheet.php?id=3589], 06/10/2011.

Bodenstein, G. \& Kroymann, B. (1967): Die Ergebnisse der Mazedonien-Exkursion der Ornithologischen Gesellschaft in Bayern im Mai/Juni 1966. - Anzeiger der Ornithologischen Gesellschaft in Bayern 8 (2): 134 157.

Danko, S. \& SzIlard, P. (I97I): Ornithologische Beobachtungen in Mazedonien, mit besonderer Berücksichttigung der Greifvögel. - Ornithologische Mitteilungen 23 (1): 9-18.

Denac, K., Mihelič, T., Božıč, L., Kmecl, P., Jančar, T., Figelu, J. \& Rubinić, B. (2OII): Strokovni predlog za revizijo posebnih območij varstva (SPA) z uporabo najnovejših kriterijev za določitev mednarodno pomembnih območij za ptice (IBA). Končno poročilo (dopolnjena verzija) za Ministrstvo za okolje in prostor. DOPPS - BirdLife Slovenia, Ljubljana.

Dimovski, A.S. (I967): Biogeografska i ekološka 
karakteristika na Skopska kotlina. - Godišen Zbornik na Prirodno-matematički fakultet na Univerzitetot vo Skopje 20: 5-70.

Dimovski, A.S. (I97IA): Zoocenološki istražuvanja na stepskite predeli vo Makedonija. - Godišen zbornik na Institutot za biologija 23: 25-43.

Dimovski, A.S. (I97IB): Sezonski izmeni na ornitofaunata vo sostoinata na prnar (Quercus coccifera) vo Makedonija. - Godišen zbornik na Institutot za biologija 23: 45-54.

EEA (2006): CORINE Land Cover 2006 (CLC2006). European Environment Agency, Copenhagen.

ESRI (2005): ArcGIS, Version 9.1. - ESRI inc., Redlands, CA.

FARMAHEM (20IO): Study for revalorization of natural values of protected area "Tikves" Strict Nature Reserve. Report to UNDP and Ministry of Environment and Physical Planning of Republic of Macedonia. - Farmahem, Skopje.

Fremuth, W., Bino, T., Bego, F., Jorgo, G., Micevski, B., Anastasovski, V., Tzvetkov, T., Hristov, I., Schneider-Jacoby, M. \& Shumka, S. (2000): Four years of simultaneous wintering waterbird census at the Ohrid and Prespa Lakes 1997-2000. pp. 30-39 In: Proceedings of the International Symposium "Sustainable development of Prespa Region«, 23-25 Jun 2000, Oteševo. - Macedonian Ecological Society and Society "Prespa", Skopje.

Ganso, M. (1962): Beobachtungen aus Jugoslawien und Nordgriechenland. - Egretta 5 (2): 60-64.

GAŠEVsKI, M. (I978): Basic hydrographic characteristics of the river network of Macedonia. - Geogarfski razgledi 15/16: 29-38.

Gengler, J. (I920): Balkanvögel. Ein ornithologisches Tagebuch. - Verlagsbuchhandlung Pierer, Altenburg \& Leipzig.

Georgiev, K. \& Iankov, P. (20Io): Species Action Plan for the Semi-collared Flycatcher Ficedula semitorquata in the European Union. - BirdLife International \& European Commission, Brussels. [http://ec.europa.eu/ environment/nature/conservation/wildbirds/action_ plans/docs/ficedula_semitorquata.pdf], 4/10/2011.

GrimmetT, R.F.A \& Jones, T.A. (I989): Important Bird Areas in Europe. Technical Publication No. 9. - International Council for Bird Preservation, Cambridge.

Grubac, B. (1994): Status of the Lanner Falcon Falco biarmicus in the Mediterranean region with particular reference to the Central Balkans. pp. 127-134 In: Muntaner, J. \& Mayol, J. (eds.). Raptors Biology and conservation of mediterranean raptors. Proceedings of the $6^{\text {th }}$ Congress on Biology and Conservation of Mediterranean Raptors, Palma de Mallorca, 22-25 Sep 1994 - SEO/BirdLife, Madrid. (in French)

Grubac, B. (1997): The present status of vultures Aegypiinae in Central Balkans. pp. 93-103. In: Actas del II congreso internacional sobre Aves Carroñeras. - Cañizares-Solán de Cabras, Cuenca.

Grubač, B. (I990): Bradan Gypaëtus barbatus L. - Sarajevo, SP »Svjetlost", Izdavačko preduzeče, Zavod za udžbenike i nastavna sredstva, Sarajevo.

GrubaČ, B.R. (1998): Population status and conservation of the Black Vulture (Aegypius monachus) in the Former
Yugoslavian Republic of Macedonia (FYR Macedonia). pp 63-68 In: Tewes, E. Sanchez, J.J., Heredia, B. \& Bijlveld van Lexmond, M. (eds.): The Black Vulture in South Eastern Europe. Proceedings of the International Symposium on the Black Vulture in South Eastern Europe and adjacent regions, 15-16 Sep 1993, Dadia, Greece. - Black Vulture Conservation Foundation \& Frankfurt Zoological Society, Palma de Mallorca.

Grubač, B. (200I): Puzgavac Tichodoroma muraria (LINNAEUS, 1866) u Srbiji i Makedoniji. - Zaštita prirode 52 (2): 65-78.

Grubač, B. (2002): Status of the Bearded Vulture (Gypaetus barbatus) in Yugoslavia and Macedonia. pp. 53-60 In: LPO FIR (ed.): Actes du colloque international "Conservation des populations de Gypaete barbu«. LPO, Paris. (in French)

Grubač, B.R. (1986/1987): The Golden Eagle (Aquila chrysaetos chrysaetos) in South-eastern Yugoslavia. - Larus 38/39: 95-135.

Grubač, B.R. (1989): The Egyptian Vulture Neophron percnopterus in Macedonia. pp 331-333. In: Meyburg, B.-U. \& Chancellor, R.D. (eds.): Raptors in the Modern World. Proceedings of the III World Conference on Birds of Prey and Owls. - WWGBP, Berlin, London and Paris.

Grubač, B.R. (I999): Distribution and Ecology of the Longlegged Buzzard (Buteo rufinus Cretzschmar, 1827) in the Central Balkans. - Contributions to the Zoogeography and Ecology of the Eastern Mediterranean Region 1: 125-130.

Grubač, B. \& Velevski, M. (20Io): The Lanner Falcon Falco biarmicus in Macedonia. - Falco 35: 9-12.

Hagemeijer, W.J.M. \& Blair, M.J. (I997): The EBCC Atlas of European Breeding Birds: Their Distribution and Abundance. - T \& A D Poyser, London.

HanžEL, J. (2OIO): Cattle Egret Bubulcus ibis. - Acrocephalus 31 (144): 57-71.

Heckenroth, H. \& Heins, J.-U. (in prep.): Weißstorch (Ciconia ciconia) Brutbestand im östlichen Makedonien im Jahr 2010. - The Stork Foundation, Berlin.

Heath, M.F. \& Evans, M.I. (eds.) (2000): Important Bird Areas in Europe: Priority sites for conservation. Vol. 2. Southern Europe. BirdLife Conservation Series No. 8. BirdLife International, Cambridge.

HölzINGER, J. (1987): Die Wacholderdrossel (Turdus pilaris) neuer Brutvogel für Makedonija (Jugoslawien). - Ökologie der Vögel 9 (2): 163-164.

Iñigo, A., \& Barov, B. (20IO): Action plan for the lesser kestrel Falco naumanni in the European Union. - BirdLife International \& European Commission, Brussels. [http://ec.europa.eu/environment/nature/conservation/ wildbirds/action_plans/docs/falco_naumanni.pdf], 4/10/2011.

Iñigo, A., Barov, B., Orhun, C. \& Gallo-Orsi, U. (2008): Action plan for the Egyptian Vulture Neophron percnopterus in the European Union. - BirdLife International \& European Commission, Brussels. [http://ec.europa.eu/environment/nature/conservation/ wildbirds/action_plans/docs/neophron_percnopterus. pdf], 4/10/2011.

IUCN (20II): The IUCN Red List of Threatened Species. 
M. Velevssi, B. Hallmann, B. Grubač, T. Lisičanec, E. Stoynov, E. Lisičanec, V. Avukatov, L. Božič \& B. Stumberger: Important Bird Areas in Macedonia: Sites of Global and European Importance

Version 2011.1 - [www.iucnredlist.org], 4/10/2011.

Kajevska, A., Ilić, D. \& Velevski, M. (I996): Rezultati od ornitološkite istražuvanja na Šar Planina '95. - Bilten na Istražuvačkoto društvo na studenti biolozi 1: 63-66.

KALABER, L. (1970): Ornithological observations in Macedonia (S.F.R. Yugoslavia). - Museum Bruckenthal (Hermannstadt, Rumänien): 315-333. (in Romanian)

Karaman, S. (1929): Ptice okoline Skoplja. - Glasnik Skopskog naučnog društva 6: 177-211. (C)

KolČAKOVSKI, D. (2004): Geotectonic characteristics of the relief in the Republic of Macedonia. - Bulletin of the Department of Physical Geography 1: 7-23. (in Macedonian)

KolČAKOvski, D. (2008): Morphological characteristics of the graben structures (depressions) in Republic of Macedonia. - Geographical Reviews (41/42): 19-42. (in Macedonian)

Kostadinova, I. \& Gramatikov, M. (eds.) (2007): Important Bird Areas in Bulgaria and Natura 2000. Conservation Series No. 11. - Bulgarian Society for the Protection of Birds, Sofia.

Kovacs, A., Barov, B., Orhun, C. \& Gallo-Orsi, U. (2008): International Species Action Plan for the European Roller Coracias garrulus garrulus. - BirdLife International \& European Commission, Brussels. [http://ec.europa.eu/environment/nature/conservation/ wildbirds/action_plans/docs/coracias_garrulus_garrulus. pdf], 4/10/2011.

LAZAREvSKI, A. (1993): The climate in Macedonia. - Kultura, Skopje. (in Macedonian)

Levkov, Z., Krstic, S., Metzeltin, D \& Nakov, T. (2007): Diatoms of Lakes Prespa and Ohrid. pp. 1-613 In: LANGe-Bertalot, H. (ed.): Iconographia Diatomologica. Annotated Diatom Micrographs. Vol. 16. Biogeography, Ecology, Taxonomy. - A.R.G. Gantner Verlag K.G., Liechtenstein.

Lisichanets, T., Stoynov, E. \& Ivanov, H. (2004): The First National Census of Lesser Kestrel (Falco naumanni) in Macedonia 2002 and FWFF Macedonia's Activities for its Conservation. pp. 90-91 In: Proceedings of the International congress "Rural ecosystems and biological richness: main threats and conservation measures". - Liga para a Protecção da Natureza, Castro Verde, Portugal.

MaKatsch, W. (1950): Die Vogelwelt Macedoniens. Akademische Verlagsgesellschaft Geest \& Portig K.-G., Leipzig.

Matvejev, S.D. (1957): Tetrebska divljač (fam. Tetraonidae) u Istočnoj Jugoslaviji. - Godišnjak Instituta za naučna istrazivanja u lovstvu 3: 5-92.

Matvejev, S.D. (1976): Pregled faune ptica Balkanskog poluostrva. Conspectus avifaunae Balcanicae. I. deo. Detlići i ptice pevačice Piciformes et Passeriformes. SANU, posebna izdanja, knjiga 46, Beograd.

Matvejev, S.D. \& VAsić, V.F. (1973): Catalogus faunae Jugoslaviae IV/3. Aves. - Slovenska akademija znanosti in umetnosti, Ljubljana.

Melovski, L., Hristovski, S., Melovski, D., KolČakovski, D., Velevski, M., Angelova, N., Levkov, Z. \& Karadelev, M. (20IO): The natural values of Šar Planina Mt. Special Issue No. 10 - Macedonian Ecological Society, Skopje.
Melovski, L., Velevski, M., Matevski, V., Avukatov, V. \& SARov, A. (in prep.): Using Important Plant Areas and Important Bird Areas to identify Key Biodiversity Areas in the Republic of Macedonia.

Micevski B. (1990): Sporedbeni populacioni istražuvanja na pticite vo dominantnite šumski zaednici na planinata Galičica. - Prirodno-matematički fakultet, Univerzitet "Sv. Kiril i Metodij), Skopje.

Micevski, B. (I99I): Analiza na faunističkiot sostav i struktura na zimskata ornitofauna na Dojranskoto Ezero. - Godišen zbornik na Institutot za biologija 43/44: 6573.

MicevsKi, B. (I996): Ohrid Lake winter ornitofauna (Faunistical and Structural Characteristics). - Godišen zbornik na Institutot za biologija 49: 85-93.

Micevski, B. (1998): Ornitofauna na Prespanskoto Ezero. - Vest, Skopje.

Micevski, B. (2000): Ornitofauna na trite prirodni ezera vo Makedonija (Prespansko, Ohridsko, Dojransko). Final report to the Ministry of Education and Science of Republic of Macedonia. - Institute of Biology, Faculty of Naturtal Sciences and Mathematics, Skopje.

MicevsKI, B. (2002/2003): Novi vidovi ptici za ornitofaunata na Republika Makedonija. - Godišen zbornik na Institutot za Biologija 55/56: 55-73.

MicevsKi, B. (2003): Avifauna of Ohrid Lake. - Bird Study and Protection Society of Macedonia, Special edition No. 5, Skopje.

Micevski, B. (20IO): Ornitofauna na NP Mavrovo. Unpublished report of the project "Protection of the Environment, Economical Development and Promotion of Sustainable Ecotourism in "Mavrovo « National Park." - Unity and Cooperation for Development of Peoples (UCODEP).

Micevski, B. \& Schneider, M. (1997): Winter census of waterfowl in Macedonian part of Prespa Lake in January 1997 (with structural, dietary and evaluation analyses). pp. 160-164 In: Proceedings of the International Symposium Towards Integrated Conservation and Sustainable Development of Transboundary Macro and Micro Prespa Lakes, 24-26 Oct 1997, Korcha.

Micevski, B., Stojanovski, L. \& Šterjova, B. (1992): Drastično opadanje gustine populacije bele rode, Ciconia ciconia u Makedoniji. - Ciconia 4: 43-49.

Puzović, S., Sekulić, G., Stojnić, N., Grubač, B. \& Tucakov, M. (2009): Important Bird Areas in Serbia. - Ministry of Environment and Spatial Planning, Institute for Nature Protection of Serbia \& Provincial Secretariat of Environmental Protection and Sustainable Development, Belgrade.

Radović, D., Kralj, J., Tutiš, V., Radović, J. And Topić, R. (2005): National Ecological Netwok - areas important for birds in Croatia. - Državni zavod za zaštitu prirode, Zagreb.

Rolevski, D., Rizovski, R., Micevski, B., Grubač, B., Ivanovski, T., Lisičanec, T., KuinČarov, S., Nastov, A., Velevski, M., \& Delov, B. (2003): Elaborate for valorization of the natural values of the ornitological locality Demir Kapija. - Ministry of Environment and Physical Planning of Republic of Macedonia, Skopje.

RuCNER, R. (1962/I964): Odnos mediteranske vegetacije i 
mediteranskih elemenata ornitofaune na Balkanskom poluotoku. - Larus 16/18: 79-105.

ŠKorpikova, V., PrašeK, V. \& VALÁŠEK, M. (2006): Ornithological notes from Macedonia in 2006. - Ciconia 15: 30-45.

Šmorpikova, V., Prašek, V., Beran, V., Dostál, M., VAlášeK, M., Thelenová, J., Polednik, L. \& PolednikovÁ, K. (2007): Birds of prey in Macedonia: notes from an ornithological expedition in 2007. Ciconia 16: 19-25.

Šnorpíková, V., Čamlík, G., Prášek, V. \& Dostál, M. (2009A): Little Tern Sterna albifrons - a new breeding species for Macedonia. - Ciconia 18: 223-224.

ŠKorpí́Ková, V., ČAmlík, G., PrášEK, V. \& Dostál, M. (2009B): Semi-collared Flycatcher Ficedula semitorquata and Red-brested Flycatcher Ficedula parva found in northern Macedonia. - Ciconia 18: 228-230.

Society for Protection of Prespa (20II): Habitats \& Threatened Species: Dalmatian Pelican. - [http:// www.spp.gr/spp/pelicantrends-table09082011.pdf], $4 / 10 / 2011$

State Statistical Office of the Republic of Macedonia (20II): Statistical Yearbook of the Republic of Macedonia 2011. - State Statistical Office of the Republic of Macedonia, Skopje.

Stresemann, E. (1920): Avifauna Macedonica. Die ornithologischen Ergebnisse der Forschungsreisen, unternommen nach Mazedonien durch Prof. Dr. Doflein und Prof. L. Müller-Mainz in den Jahren 1917 und 1918. - Dultz \& Co., München.

Štumberger, B. \& Velevski, M. (2002): White Stork Ciconia ciconia survey in Pelagonia indicates a decrease in its breeding population and colony disintegration. Acrocephalus 23 (112): 67-74.

Terrasse, J.F. \& Terrasse, M. (I96I): Ornithological impressions from Yugoslavia (1959). - L'Oiseau et R.F.O. 31 (1): 53-69. (in French)

Terrasse, J.F. \& Terrasse, M. (I96I): Ornithological impressions from Yugoslavia (1959) (continuation and end). - L'Oiseau et R.F.O. 31 (2): 111-129. (in French)

Thönen W. (2006): Pelagonien (Mazedonien) einst und heute (1). - Ornis 3: 10-11.

Trpkov, B., Dončev, I. \& Drozdovski, I. (I978): Lovečki priračnik. - Sojuz na lovečkite organizacii na Makedonija, Skopje.

VAsIĆ, V. (2009A): Study for the natural values of the Ezerani Nature Reserve: Birds. - Unpublished report to United Nations Development Programme (UNDP).

VAsić, V. (2009B): Winter census of waterbirds of the pilot protected area "Tikvesh«. Report for the project "Strengthening the ecological, institutional and financial sustainability of Macedonia's national protected areas system. Management plan of the protected area "Tikveš». - Ministry of Environment and Physical Planning of Republic of Macedonia \& United Nations Development Programme (UNDP).

VAsıć, V. (2OIO): List of Birds of the National Park Galičica. Report for the management plan of the NP Galičica. Public enterprise National park "Galičica”, Ohrid.

Vasić, V., Grubač, B., Su'ić, G. \& Marinković, S. (I985): The Status of Birds of Prey in Yugoslavia, with Particular
Reference to Macedonia. pp. 45-53 In: Newton, I. \& Chancellor, R.D. (eds.): Conservation Studies on Raptors, ICBP Technical Publication Series No. 5. Princeton University Press, Cambridge.

Vasıć, V., Popović, Z., Radaković, M. \& RuŽıć, M. (2009): Siva čiopa Apus pallidus u Srbiji i Makedoniji. - Ciconia 18: $132-142$.

VelevsKi, M. (2008): Evaluation of bird fauna at Matka Canyon, Macedonia. - Natura Montenegrina 7 (2): 369-380.

Velevski, M. (20II): Non-critical checklist of birds of Macedonia. - [http://www.mes.org.mk/PDFs/Other/ Checklist\%20of\%20birds\%20of\%20Macedonia.pdf], $12 / 09 / 2011$

Velevski, M. \& Grubač, B. (2008): Distribution and estimation of the population size of the Short-toed Snake-eagle Circaetus gallicus in Macedonia. pp. 22-24 In: Proceedings of the $3^{\text {rd }}$ Congress of Ecologists of the Republic of Macedonia with International Participation, 6-9 Sep 2007, Struga. - Special Issues of the Macedonian Ecological Society, Vol. 8, Skopje.

Velevski, M. \& Saveljić, D. (20IO): Great Black-headed Gull Larus ichthyaetus. - Acrocephalus 31 (144): 57-71.

Velevski, M. \& Stumberger, B. (20IIA): List of ornithological references on Macedonia. - [http:// www.mes.org.mk/PDFs/Other/References\%20on\%20 birds\%20of\%20Macedonia\%.pdf], 12/09/2011.

Velevski, M. \& Stumberger, B. (20IiB): Review of the references on birds of Macedonia. - Acrocephalus 31 (147): 283-291.

Velevski, M., Dimitrovska, E. \& Karčicki V. (2002A): Prilog kon ornitofaunata na Šar Planina. - Bilten na Istražuvačkoto društvo na studenti biolozi 2: 153-160.

Velevski, M., Dimitrovska, E., Božıč, L., Karčicki, V. \& Pop-Trajkov, M. (2002B): Prilog kon ornitofaunata na masivot Jakupica. - Bilten na Istražuvačkoto društvo na studenti biolozi 2: 161-169.

Velevski, M., Melovski, L., Maletik, V., Dzabirski, V. \& Hristovski, S. (2003): Food availability for vultures (Aegypiinae) in Macedonia. Report for Black Vulture Conservation Foundation \& Frankfurt Zoological Society. - Macedonian Ecological Society, Skopje.

Velevski, M., Grubač, B. \& Hallmann, B. (2008): Distribution and estimation of the population size of the Black Stork Ciconia nigra in Macedonia. - Ciconia 17: 14-19.

Velevski, M., Pop-Trajkov, M,. Andevski, J. \& Dimitrovska, E. (2003A): Istražuvanja na letniot aspekt na ornitofaunata na planinata Pelister. - Bilten na Istražuvačkoto društvo na studenti biolozi 3: 71-75.

Velevski, M., Pop-Trajkov, M. \& Andevski, J. (2003B): Podatoci za ornitofaunata na planinata Bistra. - Bilten na Istražuvačkoto društvo na studenti biolozi 3: 77-86.

Wetlands InTERnATIONAL (2006): Waterbird Population Estimates. Fourth Edition. - Wetlands International, Wageningen.

Arrived / Prispelo: 27.6.2011

Accepted / Sprejeto: 20.12.2011 
M. Velevski, B. Hallmann, B. Grubač, T. Lisičanec, E. Stoynov, E. Lisičanec, V. Avukatov, L. Božič \& B. Stumberger: Important Bird Areas in Macedonia: Sites of Global and European Importance

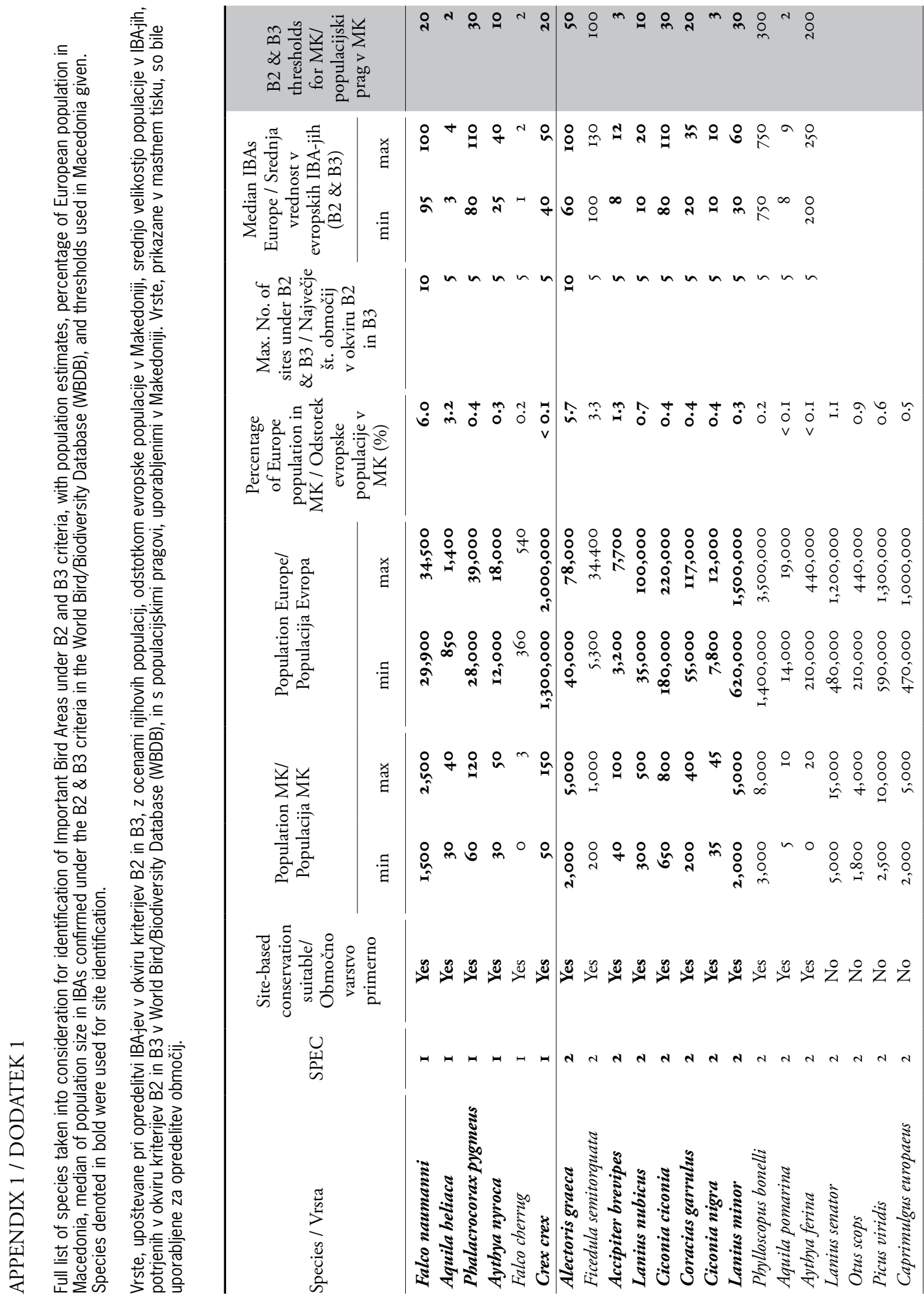




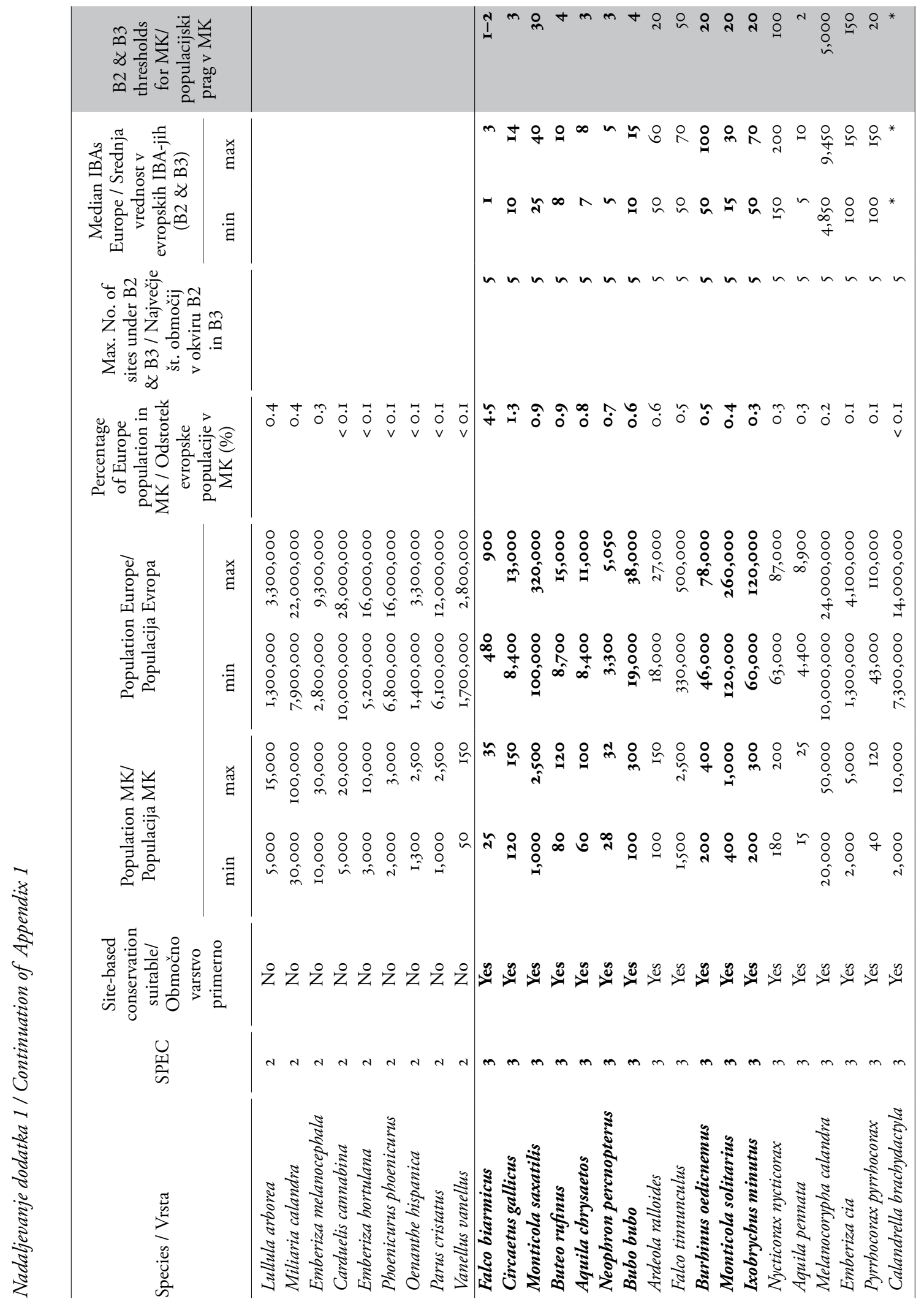


M. Velevski, B. Hallmann, B. Grubač, T. Lisičanec, E. Stoynov, E. Lisičanec, V. Avukatov, L. Božič \& B. Stumberger: Important Bird Areas in Macedonia: Sites of Global and European Importance

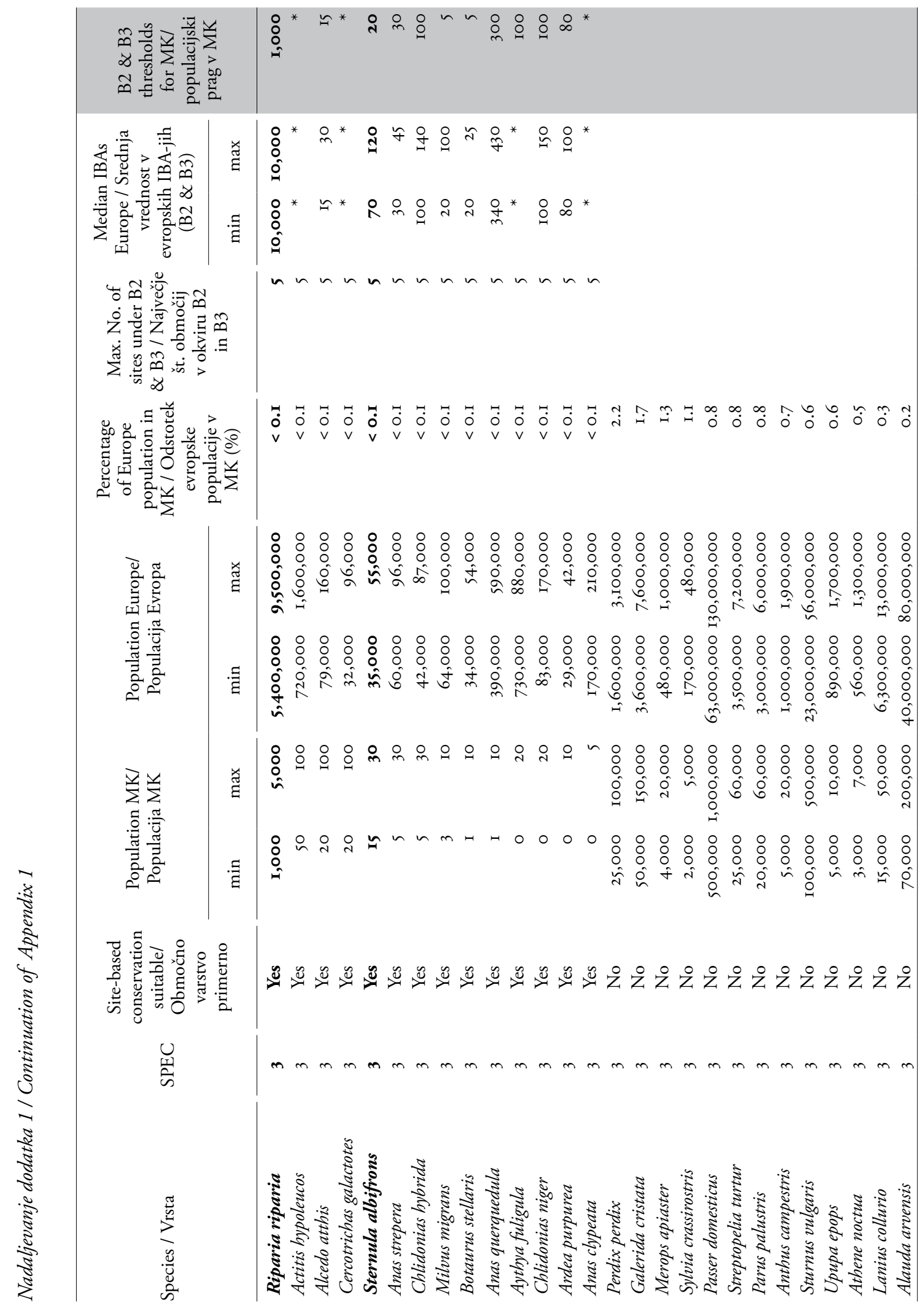




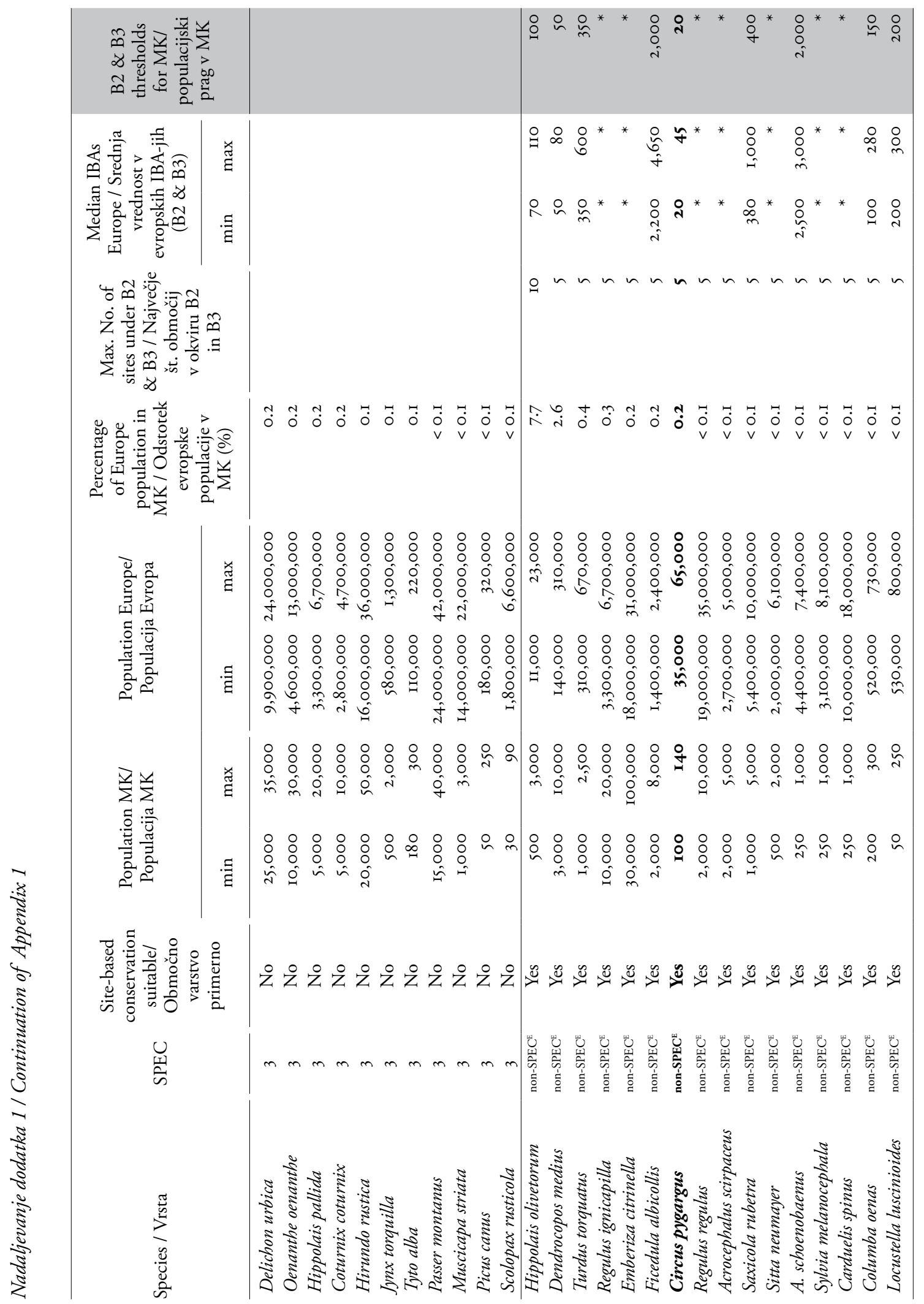


M. Velevski, B. Hallmann, B. Grubač, T. Lisičanec, E. Stoynov, E. Lisičanec, V. Avukatov, L. Božič \& B. Stumberger: Important Bird Areas in Macedonia: Sites of Global and European Importance

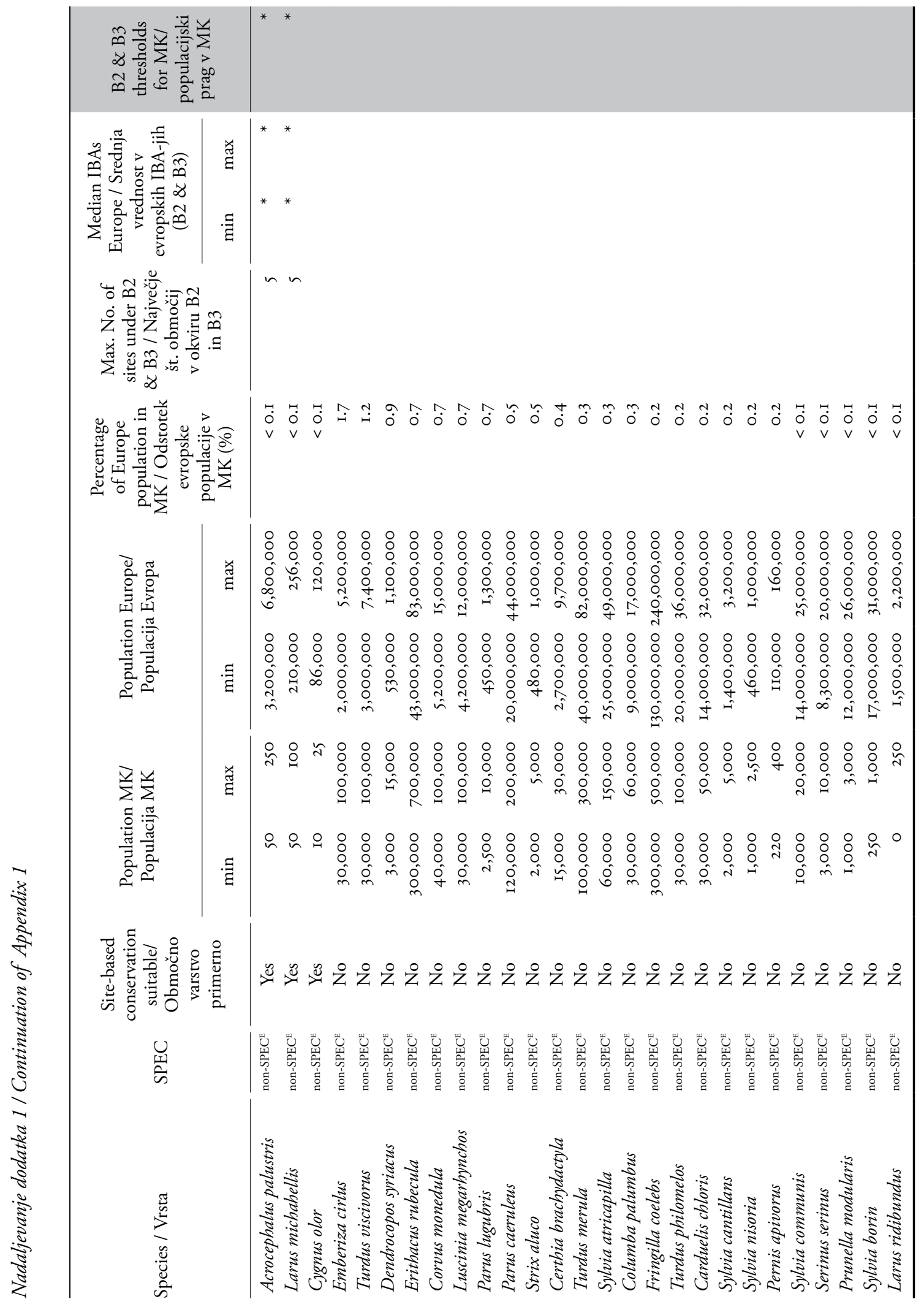




\section{Nadaljevanje dodatka 1 / Continuation of Appendix 1}

* Few or no IBAs identified for the species under the B2 \& B3 criteria in the World Bird/Biodiversity Database (WBDB)

Population estimates refer to breeding pairs after BirdLife International (2004), except Falco naumanni, Coracias garrulus, Neophron percnopterus and Ficedula semitorquata, where data from the action plans were used (INIGO et al. 2008, KovaCs et al. 2008, GeOrgiev \& IANKov 20IO, INIGI \& Barov 20IO) SPEC - species of European conservation concern (SPEC 1 - European species of global conservation concern in Europe, i.e. classified as Critically Endangered, Endangered, Vulnerable, Near Threatened or Data Deficient under the IUCN Red List Criteria at a global level; SPEC 2 - species whose global populations are concentrated in Europe, and which have an Unfavourable conservation status in Europe; SPEC 3 - species whose global populations are not concentrated in Europe, but which have an Unfavourable conservation status in Europe; non-SPEC ${ }^{\mathrm{E}}$ - species whose global populations are concentrated in Europe but which have a Favourable conservation status in Europe) (BIrDLife InTERNATIONAL 2004) 
M. Velevski, B. Hallmann, B. Grubač, T. Lisičanec, E. Stoynov, E. Lisičanec, V. Avukatov, L. Božič \& B. Stumberger: Important Bird Areas in Macedonia: Sites of Global and European Importance

\section{APPENDIX 2 / DODATEK 2}

The overall classification of the major CORINE land cover types found within IBA boundaries in Macedonia

Celotna razvrstitev glavnih tipov pokrovnosti in rabe tal (po CORINE land cover) znotraj meja IBA-jev v Makedoniji

\begin{tabular}{|c|c|c|}
\hline Level $1 / 1$. nivo & Level 2 / 2. nivo & Level 3 / 3. nivo \\
\hline \multirow[t]{5}{*}{ 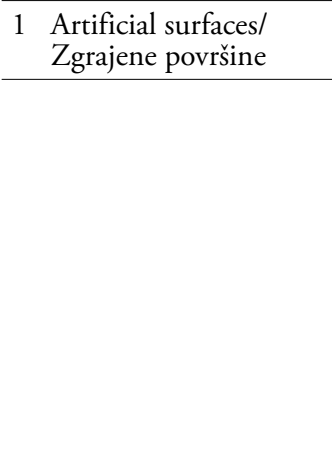 } & 11 Urban fabric / Urbane površine & $112 \begin{array}{l}\text { Discontinuous urban fabricl } \\
\text { Nesklenjene urbane površine }\end{array}$ \\
\hline & $\begin{array}{l}12 \text { Industrial, commercial and } \\
\text { transport units / Industrijske, } \\
\text { trgovinske, transportne površine }\end{array}$ & $\begin{array}{l}121 \text { Industrial or commercial units/ } \\
\text { Industrija, trgovina } \\
122 \text { Road and rail networks and associated } \\
\text { land / Cestno in železniško omrežje in } \\
\text { pridružene površine }\end{array}$ \\
\hline & $\begin{array}{l}13 \text { Mine, dump and construction sites/ } \\
\text { Rudniki, odlagališča, gradbišča }\end{array}$ & $\begin{array}{l}131 \text { Mineral extraction sites/ } \\
\text { Dnevni kopi, kamnolomi }\end{array}$ \\
\hline & & 132 Dump sites / Odlagališča \\
\hline & $\begin{array}{l}14 \text { Artificial, non-agricultural } \\
\text { vegetated areas / Umetno } \\
\text { ozelenjene nekmetijske površine }\end{array}$ & $\begin{array}{l}142 \text { Sport and leisure facilities/ } \\
\text { Površine za šport in prosti čas }\end{array}$ \\
\hline \multirow[t]{8}{*}{ 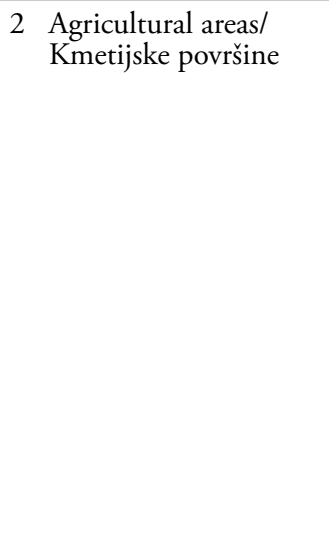 } & 21 Arable land / Njivske površine & 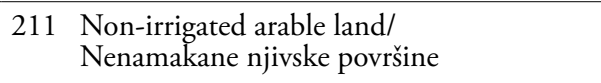 \\
\hline & & $\begin{array}{l}212 \text { Permanently irrigated land/ } \\
\text { Namakane njivske površine }\end{array}$ \\
\hline & & 213 Rice fields / Riževa polja \\
\hline & 22 Permanent crops / Trajni nasadi & 221 Vineyards / Vinogradi \\
\hline & & $\begin{array}{l}222 \text { Fruit trees and berry plantations/ } \\
\text { Sadovnjaki in nasadi jagodičja }\end{array}$ \\
\hline & 23 Pastures / Pašniki & 231 Pastures / Pašniki \\
\hline & $\begin{array}{l}24 \text { Heterogeneous agricultural areas/ } \\
\text { Mešane kmetijske površine }\end{array}$ & $\begin{array}{l}242 \text { Complex cultivation patterns / Kmetijske } \\
\text { površine drobnoposestniške strukture }\end{array}$ \\
\hline & & $\begin{array}{l}243 \text { Land principally occupied by agriculture, } \\
\text { with significant areas of natural vegetation/ } \\
\text { Pretežno kmetijske površine z večjimi } \\
\text { območji naravne vegetacije }\end{array}$ \\
\hline \multirow{10}{*}{$\begin{array}{l}\text { Forest and semi } \\
\text { natural areas / Go } \\
\text { in deloma ohranje } \\
\text { naravne površine }\end{array}$} & 31 Forests / Gozdovi & 311 Broad-leaved forest / Listnati gozd \\
\hline & & 312 Coniferous forest / Iglasti gozd \\
\hline & & 313 Mixed forest / Mešani gozd \\
\hline & 32 Scrub and/or herbaceous & 321 Natural grasslands / Naravni travniki \\
\hline & $\begin{array}{l}\text { vegetation associations/ } \\
\text { Grmovje in/ali zeliščno rastlinstvo }\end{array}$ & 322 Moors and heathland / Barja in resave \\
\hline & & $\begin{array}{l}323 \text { Sclerophyllous vegetation/ } \\
\text { Sklerofilno rastlinstvo }\end{array}$ \\
\hline & & $\begin{array}{l}324 \text { Transitional woodland-shrub/ } \\
\text { Grmičast gozd }\end{array}$ \\
\hline & $\begin{array}{l}33 \text { Open spaces with little or no } \\
\text { vegetation / Neporasle površine }\end{array}$ & $\begin{array}{l}331 \text { Beaches, dunes, sands/ } \\
\text { Plaže, sipine in peščene površine }\end{array}$ \\
\hline & z malo ali brez vegetacije & 332 Bare rocks / Golo skalovje \\
\hline & & $\begin{array}{l}333 \text { Sparsely vegetated areas/ } \\
\text { Redko porasle površine }\end{array}$ \\
\hline $\begin{array}{l}4 \text { Wetlands/ } \\
\text { Močvirnate površine }\end{array}$ & 41 Inland wetlands / Celinska močvirja & 411 Inland marshes / Celinska barja \\
\hline \multirow{2}{*}{$\begin{array}{l}5 \text { Water bodies/ } \\
\text { Vodne površine }\end{array}$} & 51 Inland waters / Celinske vode & 511 Water courses / Vodotoki in kanali \\
\hline & & 512 Water bodies / Mirujoča voda \\
\hline
\end{tabular}




\section{APPENDIX 3 / DODATEK 3}

List from the national Emerald Database, used for identification of the main threats to birds and their importance in Macedonian IBAs

Seznam iz nacionalne baze podatkov Emerald, uporabljen za opredelitev najpomembnejših dejavnikov ogrožanja ptic in njihovega vpliva v makedonskih IBA-jih

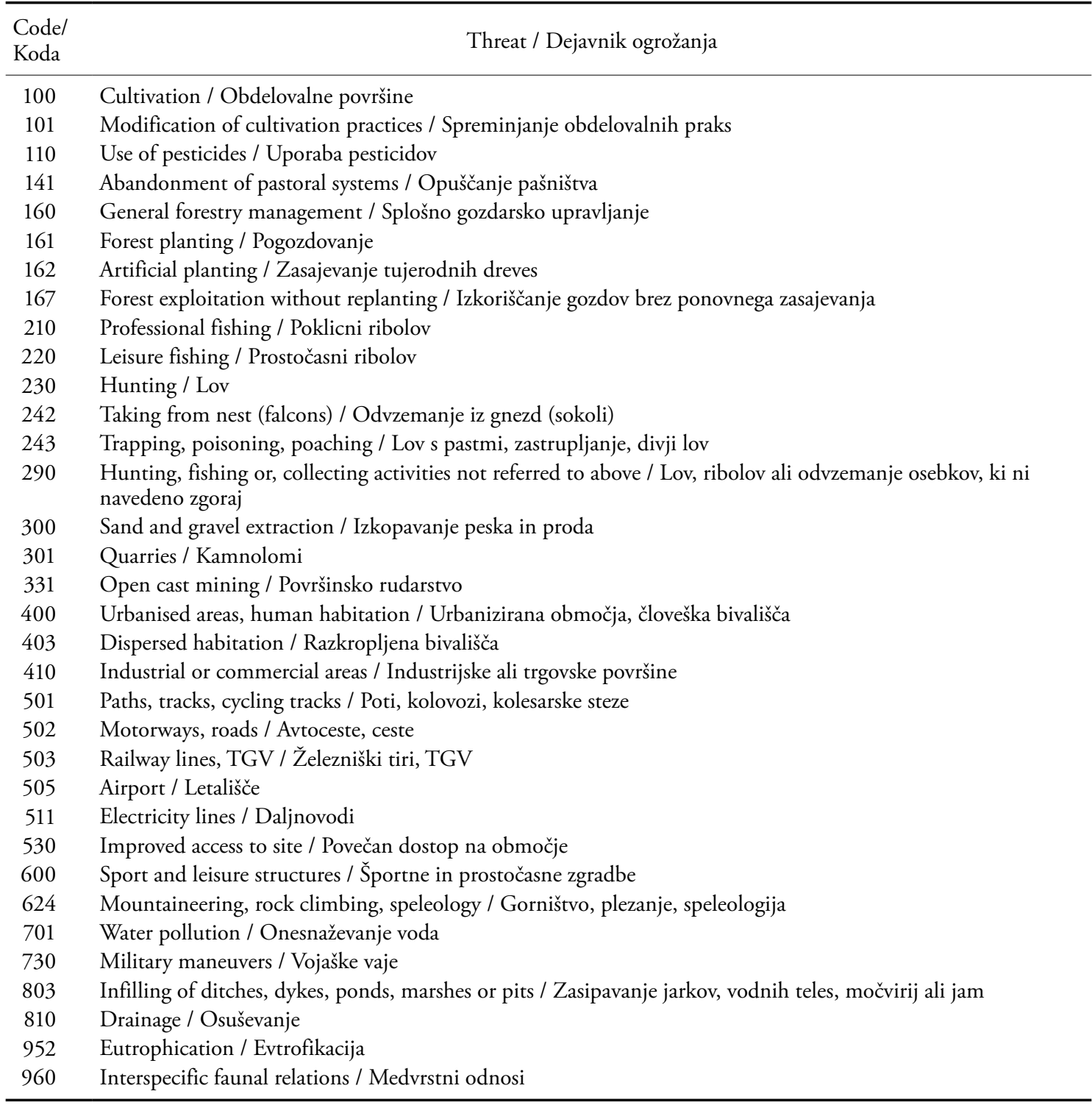


M. Velevski, B. Hallmann, B. Grubač, T. Lisičanec, E. Stoynov, E. Lisičanec, V. Avukatov, L. Božič \& B. Stumberger: Important Bird Areas in Macedonia: Sites of Global and European Importance

\section{APPENDIX 4 / DODATEK 4}

Detailed calculation of threat scores for seperate IBAs.

Podroben izračun dejavnikov ogrožanja za posamezne IBA-je.

\begin{tabular}{|c|c|c|c|c|c|c|c|}
\hline Site / Območje & $\begin{array}{l}\text { Code/ } \\
\text { Koda }\end{array}$ & $\begin{array}{c}\text { Effect } \\
\text { habitat/ } \\
\text { Učinek } \\
\text { habitat }\end{array}$ & $\begin{array}{l}\text { Effect } \\
\text { species/ } \\
\text { Učinek } \\
\text { vrsta }\end{array}$ & $\begin{array}{l}\text { Spatial } \\
\text { scale/ } \\
\text { Obseg }\end{array}$ & $\begin{array}{c}\text { Realization/ } \\
\text { Časovni } \\
\text { okvir }\end{array}$ & $\begin{array}{l}\text { Score/ } \\
\text { Vsota }\end{array}$ & $\begin{array}{l}\text { Threat } \\
\text { impact/ } \\
\text { Vpliv }\end{array}$ \\
\hline \multirow[t]{10}{*}{ Šar Planina Mountain } & $\mathrm{I} 4 \mathrm{I}$ & I & 2 & 3 & 3 & 8 & high \\
\hline & 160 & 2 & I & 3 & 3 & 8 & high \\
\hline & 960 & & 2 & 3 & 3 & 8 & high \\
\hline & 230 & & I & 3 & 3 & 7 & medium \\
\hline & 243 & & 2 & 2 & 3 & 7 & medium \\
\hline & 501 & 2 & 2 & 2 & 3 & 7 & medium \\
\hline & 530 & I & 2 & 2 & 3 & 7 & medium \\
\hline & 167 & 2 & I & 2 & 3 & 6 & medium \\
\hline & 624 & & 2 & I & 3 & 6 & medium \\
\hline & 600 & 2 & 2 & I & 2 & 5 & low \\
\hline \multirow[t]{8}{*}{ Radika River Catchment } & 960 & & 2 & 3 & 3 & 8 & high \\
\hline & I4I & I & 2 & 2 & 3 & 7 & medium \\
\hline & 160 & I & I & 2 & 3 & 6 & medium \\
\hline & 243 & & 2 & I & 3 & 6 & medium \\
\hline & 410 & I & 2 & 2 & 2 & 6 & medium \\
\hline & 501 & I & I & I & 3 & 5 & low \\
\hline & 624 & & I & I & 3 & 5 & low \\
\hline & 530 & I & I & I & 2 & 4 & low \\
\hline \multirow[t]{2}{*}{ Lake Ohrid } & 600 & 3 & 2 & 2 & 3 & 8 & high \\
\hline & 803 & 3 & 2 & 2 & 3 & 8 & high \\
\hline \multirow[t]{6}{*}{ Lake Prespa } & IOO & 3 & I & 2 & 3 & 8 & high \\
\hline & 701 & 2 & 2 & 3 & 3 & 8 & high \\
\hline & 952 & 2 & 2 & 3 & 3 & 8 & high \\
\hline & 243 & & 2 & 2 & 3 & 7 & medium \\
\hline & 600 & I & I & 2 & 3 & 6 & medium \\
\hline & 803 & 2 & 2 & I & 3 & 6 & medium \\
\hline \multirow[t]{10}{*}{ Demir Kapija Gorge } & 243 & & 3 & 3 & 3 & 9 & high \\
\hline & I4I & 2 & 2 & 3 & 3 & 8 & high \\
\hline & 230 & & 2 & 3 & 3 & 8 & high \\
\hline & 160 & 2 & 2 & 2 & 3 & 7 & medium \\
\hline & 502 & 3 & 2 & 2 & 2 & 7 & medium \\
\hline & 624 & & 2 & 2 & 3 & 7 & medium \\
\hline & 301 & I & 2 & I & 3 & 6 & medium \\
\hline & 410 & & 2 & 3 & I & 6 & medium \\
\hline & 730 & & 2 & I & 3 & 6 & medium \\
\hline & 400 & I & I & I & 3 & 5 & low \\
\hline \multirow[t]{3}{*}{ Lake Dojran } & 410 & & 3 & 3 & 3 & 9 & high \\
\hline & 210 & & 3 & 3 & 2 & 8 & high \\
\hline & 600 & 2 & 3 & 2 & 3 & 8 & high \\
\hline \multirow[t]{3}{*}{ Zletovska River Valley } & $\mathrm{I} 4 \mathrm{I}$ & I & 3 & 3 & 3 & 9 & high \\
\hline & 243 & & 3 & 3 & 3 & 9 & high \\
\hline & IOI & I & 2 & I & 3 & 6 & medium \\
\hline
\end{tabular}


Nadaljevanje dodatka 4 / Continuation of Appendix 4

\begin{tabular}{|c|c|c|c|c|c|c|c|}
\hline Site / Območje & $\begin{array}{l}\text { Codel } \\
\text { Koda }\end{array}$ & $\begin{array}{l}\text { Effect } \\
\text { habitat/ } \\
\text { Učinek } \\
\text { habitat }\end{array}$ & $\begin{array}{c}\text { Effect } \\
\text { species/ } \\
\text { Ǔ́inek } \\
\text { vrsta }\end{array}$ & $\begin{array}{c}\text { Spatial } \\
\text { scale/ } \\
\text { Obseg }\end{array}$ & $\begin{array}{c}\text { Realization/ } \\
\text { Časovni } \\
\text { okvir }\end{array}$ & $\begin{array}{l}\text { Score/ } \\
\text { Vsota }\end{array}$ & $\begin{array}{c}\text { Threat } \\
\text { impact/ } \\
\text { Vpliv }\end{array}$ \\
\hline & $4 \mathrm{IO}$ & $\mathrm{I}$ & 2 & 2 & 2 & 6 & medium \\
\hline \multirow[t]{5}{*}{ Tikveš Region } & IIO & & 3 & 3 & 3 & 9 & high \\
\hline & 243 & & 2 & 3 & 3 & 8 & high \\
\hline & $\mathrm{I} 4 \mathrm{I}$ & 2 & 2 & 2 & 3 & 7 & medium \\
\hline & $5 \mathrm{II}$ & 2 & 2 & 2 & 3 & 7 & medium \\
\hline & 502 & 2 & 2 & I & 3 & 6 & medium \\
\hline \multirow{9}{*}{$\begin{array}{l}\text { Pčinja - Petrošnica - Kriva } \\
\text { Reka Rivers }\end{array}$} & $\mathrm{I} 4 \mathrm{I}$ & I & 2 & 3 & 3 & 8 & high \\
\hline & 243 & & 2 & 3 & 3 & 8 & high \\
\hline & 230 & & I & 3 & 3 & 7 & medium \\
\hline & 160 & 2 & 2 & I & 3 & 6 & medium \\
\hline & 242 & & 2 & I & 3 & 6 & medium \\
\hline & $4 \mathrm{IO}$ & 2 & 2 & 2 & 2 & 6 & medium \\
\hline & 502 & 2 & 2 & 2 & 2 & 6 & medium \\
\hline & 503 & 2 & 2 & 2 & 2 & 6 & medium \\
\hline & 701 & I & I & 2 & 3 & 6 & medium \\
\hline \multirow[t]{5}{*}{ Preod - Gjugjance } & $\mathrm{I} 4 \mathrm{I}$ & 2 & 3 & 3 & 3 & 9 & high \\
\hline & SII & 2 & 3 & 3 & 3 & 9 & high \\
\hline & $4 \mathrm{IO}$ & 2 & 3 & 2 & 2 & 7 & medium \\
\hline & 502 & 2 & 3 & 2 & 2 & 7 & medium \\
\hline & 505 & 3 & 3 & 2 & 2 & 7 & medium \\
\hline \multirow[t]{5}{*}{ Osogovo Mountains } & 160 & 2 & 2 & 3 & 3 & 8 & high \\
\hline & 242 & & 2 & 3 & 3 & 8 & high \\
\hline & 403 & I & 2 & 2 & 3 & 7 & medium \\
\hline & 502 & 2 & 2 & 2 & 3 & 7 & medium \\
\hline & 301 & 2 & 2 & I & 3 & 6 & medium \\
\hline \multirow[t]{4}{*}{ Jakupica Mountain } & $\mathrm{I} 4 \mathrm{I}$ & 2 & 2 & 3 & 3 & 8 & high \\
\hline & 243 & & 2 & 3 & 3 & 8 & high \\
\hline & 960 & & 2 & 3 & 3 & 8 & high \\
\hline & 230 & & I & 2 & 3 & 6 & medium \\
\hline \multirow[t]{11}{*}{ Taor Gorge } & 960 & & 3 & 3 & 3 & 9 & high \\
\hline & 410 & 3 & 3 & 3 & 2 & 8 & high \\
\hline & 502 & 2 & 2 & 3 & 3 & 8 & high \\
\hline & 162 & 2 & 2 & 2 & 3 & 7 & medium \\
\hline & 230 & & 2 & 2 & 3 & 7 & medium \\
\hline & 301 & 2 & 3 & 2 & 2 & 7 & medium \\
\hline & 501 & I & 2 & 2 & 3 & 7 & medium \\
\hline & 503 & 2 & 2 & 2 & 3 & 7 & medium \\
\hline & 530 & 2 & 2 & 2 & 3 & 7 & medium \\
\hline & 701 & I & I & 3 & 3 & 7 & medium \\
\hline & 220 & & I & 2 & 3 & 6 & medium \\
\hline \multirow[t]{4}{*}{ Ovče Pole } & IIO & & 3 & 3 & 3 & 9 & high \\
\hline & I4I & 2 & 3 & 3 & 3 & 9 & high \\
\hline & SII & 2 & 3 & 3 & 3 & 9 & high \\
\hline & 243 & & 2 & 3 & 3 & 8 & high \\
\hline
\end{tabular}


M. Velevski, B. Hallmann, B. Grubač, T. Lisičanec, E. Stoynov, E. Lisičanec, V. Avukatov, L. Božič \& B. Stumberger: Important Bird Areas in Macedonia: Sites of Global and European Importance

Nadaljevanje dodatka 4 / Continuation of Appendix 4

\begin{tabular}{|c|c|c|c|c|c|c|c|}
\hline Site / Območje & $\begin{array}{l}\text { Codel } \\
\text { Koda }\end{array}$ & $\begin{array}{l}\text { Effect } \\
\text { habitat/ } \\
\text { Učinek } \\
\text { habitat }\end{array}$ & $\begin{array}{c}\text { Effect } \\
\text { species/ } \\
\text { Učinek } \\
\text { vrsta }\end{array}$ & $\begin{array}{l}\text { Spatial } \\
\text { scale/ } \\
\text { Obseg }\end{array}$ & $\begin{array}{c}\text { Realization/ } \\
\text { Časovni } \\
\text { okvir }\end{array}$ & $\begin{array}{l}\text { Score/ } \\
\text { Vsota }\end{array}$ & $\begin{array}{c}\text { Threat } \\
\text { impact/ } \\
\text { Vpliv }\end{array}$ \\
\hline & I6I & 2 & 2 & 2 & 3 & 7 & medium \\
\hline & 230 & & I & 3 & 3 & 7 & medium \\
\hline & 290 & & 2 & 2 & 3 & 7 & medium \\
\hline & $4 \mathrm{IO}$ & I & 2 & 2 & 2 & 6 & medium \\
\hline \multirow{9}{*}{$\begin{array}{l}\text { Topolka - Babuna - } \\
\text { Bregalnica Rivers }\end{array}$} & I4I & I & 2 & 3 & 3 & 8 & high \\
\hline & 243 & & 2 & 3 & 3 & 8 & high \\
\hline & 960 & & 2 & 3 & 3 & 8 & high \\
\hline & IOO & I & 2 & 2 & 3 & 7 & medium \\
\hline & 162 & 2 & 2 & 2 & 3 & 7 & medium \\
\hline & 230 & & I & 3 & 3 & 7 & medium \\
\hline & 403 & 2 & 2 & 2 & 3 & 7 & medium \\
\hline & 624 & & 2 & 2 & 3 & 7 & medium \\
\hline & $30 \mathrm{I}$ & 2 & 2 & $\mathrm{I}$ & 3 & 6 & medium \\
\hline \multirow{6}{*}{$\begin{array}{l}\text { Gradsko - Rosoman - } \\
\text { Negotino }\end{array}$} & IIO & & 2 & 3 & 3 & 8 & high \\
\hline & 243 & & 2 & 3 & 3 & 8 & high \\
\hline & SII & 2 & 2 & 3 & 3 & 8 & high \\
\hline & IOO & I & 2 & 2 & 3 & 7 & medium \\
\hline & I6I & 2 & 2 & 2 & 3 & 7 & medium \\
\hline & 730 & & 2 & I & 3 & 6 & medium \\
\hline \multirow{4}{*}{$\begin{array}{l}\text { Lake Mantovo and Kriva } \\
\text { Lakavica River }\end{array}$} & 242 & & 2 & 2 & 3 & 7 & medium \\
\hline & 243 & & I & 3 & 3 & 7 & medium \\
\hline & $33 \mathrm{I}$ & 3 & 2 & I & 3 & 7 & medium \\
\hline & $7 \mathrm{OI}$ & 2 & 2 & 2 & 3 & 7 & medium \\
\hline \multirow[t]{5}{*}{ Raec River valley } & 960 & & 2 & 3 & 3 & 8 & high \\
\hline & $\mathrm{I} 4 \mathrm{I}$ & 2 & 2 & 2 & 3 & 7 & medium \\
\hline & 301 & I & 3 & I & 3 & 7 & medium \\
\hline & 403 & 2 & 2 & 2 & 3 & 7 & medium \\
\hline & 243 & & 2 & I & 3 & 6 & medium \\
\hline \multirow[t]{5}{*}{ Pelagonia } & IOO & 2 & 3 & 3 & 3 & 9 & high \\
\hline & IIO & & 3 & 3 & 3 & 9 & high \\
\hline & I4I & 2 & 3 & 3 & 3 & 9 & high \\
\hline & $5 \mathrm{II}$ & 2 & 3 & 3 & 2 & 8 & high \\
\hline & 803 & $\mathrm{I}$ & 2 & 3 & 3 & 8 & high \\
\hline \multirow[t]{8}{*}{ Mariovo } & $\mathrm{I} 4 \mathrm{I}$ & 2 & 3 & 3 & 3 & 9 & high \\
\hline & 243 & & 3 & 3 & 3 & 9 & high \\
\hline & 960 & & 3 & 3 & 3 & 9 & high \\
\hline & 230 & & 2 & 3 & 3 & 8 & high \\
\hline & $3 \mathrm{OI}$ & 2 & 2 & 2 & 3 & 7 & medium \\
\hline & $4 \mathrm{IO}$ & 3 & 3 & 3 & I & 7 & medium \\
\hline & 530 & 2 & 2 & 2 & 3 & 7 & medium \\
\hline & 624 & & I & I & 3 & 5 & low \\
\hline \multirow[t]{3}{*}{ Lake Tikveš } & 243 & & 3 & 3 & 3 & 9 & high \\
\hline & 403 & 2 & 2 & 3 & 3 & 8 & high \\
\hline & I4I & 2 & 2 & 2 & 3 & 7 & medium \\
\hline
\end{tabular}


Nadaljevanje dodatka 4 / Continuation of Appendix 4

\begin{tabular}{|c|c|c|c|c|c|c|c|}
\hline Site / Območje & $\begin{array}{c}\text { Code/ } \\
\text { Koda }\end{array}$ & $\begin{array}{l}\text { Effect } \\
\text { habitat/ } \\
\text { Učinek } \\
\text { habitat }\end{array}$ & $\begin{array}{l}\text { Effect } \\
\text { species/ } \\
\text { Učinek } \\
\text { vrsta }\end{array}$ & $\begin{array}{l}\text { Spatial } \\
\text { scale/ } \\
\text { Obseg }\end{array}$ & $\begin{array}{c}\text { Realization/ } \\
\text { Časovni } \\
\text { okvir }\end{array}$ & $\begin{array}{l}\text { Score/ } \\
\text { Vsota }\end{array}$ & $\begin{array}{l}\text { Threat } \\
\text { impact/ } \\
\text { Vpliv }\end{array}$ \\
\hline & 160 & 2 & 2 & 2 & 3 & 7 & medium \\
\hline & $5 \mathrm{II}$ & & 2 & 2 & 3 & 7 & medium \\
\hline \multirow[t]{5}{*}{ Bošavija } & I4I & 2 & 3 & 3 & 3 & 9 & high \\
\hline & 243 & & 3 & 3 & 3 & 9 & high \\
\hline & 160 & 2 & 2 & 2 & 3 & 7 & medium \\
\hline & $5 \mathrm{II}$ & 2 & I & 2 & 3 & 7 & medium \\
\hline & 400 & I & $\mathrm{I}$ & 2 & 3 & 6 & medium \\
\hline \multirow[t]{3}{*}{ Kočani Rice Fields } & IIO & I & 2 & 3 & 3 & 8 & high \\
\hline & $5 \mathrm{II}$ & I & 2 & 2 & 3 & 7 & medium \\
\hline & IOI & 2 & 2 & 2 & 2 & 6 & medium \\
\hline \multirow[t]{4}{*}{ Lower Vardar } & 300 & 3 & 3 & 2 & 3 & 8 & high \\
\hline & $4 \mathrm{IO}$ & 3 & 2 & 3 & 2 & 8 & high \\
\hline & $8 \mathrm{IO}$ & 3 & 2 & 2 & 3 & 8 & high \\
\hline & $5 \mathrm{II}$ & I & 2 & 2 & 3 & 7 & medium \\
\hline
\end{tabular}

* The combined level of the threat is calculated by summing up the (1) Effect habitat / Effect species, (2) Spatial scale and (3) Realization values. Under the (1) the highest value of both is taken into consideration in calculation of the score. 
M. Velevski, B. Hallmann, B. Grubač, T. Lisičanec, E. Stoynov, E. Lisičanec, V. Avukatov, L. Božič \& B. Stumberger: Important Bird Areas in Macedonia: Sites of Global and European Importance

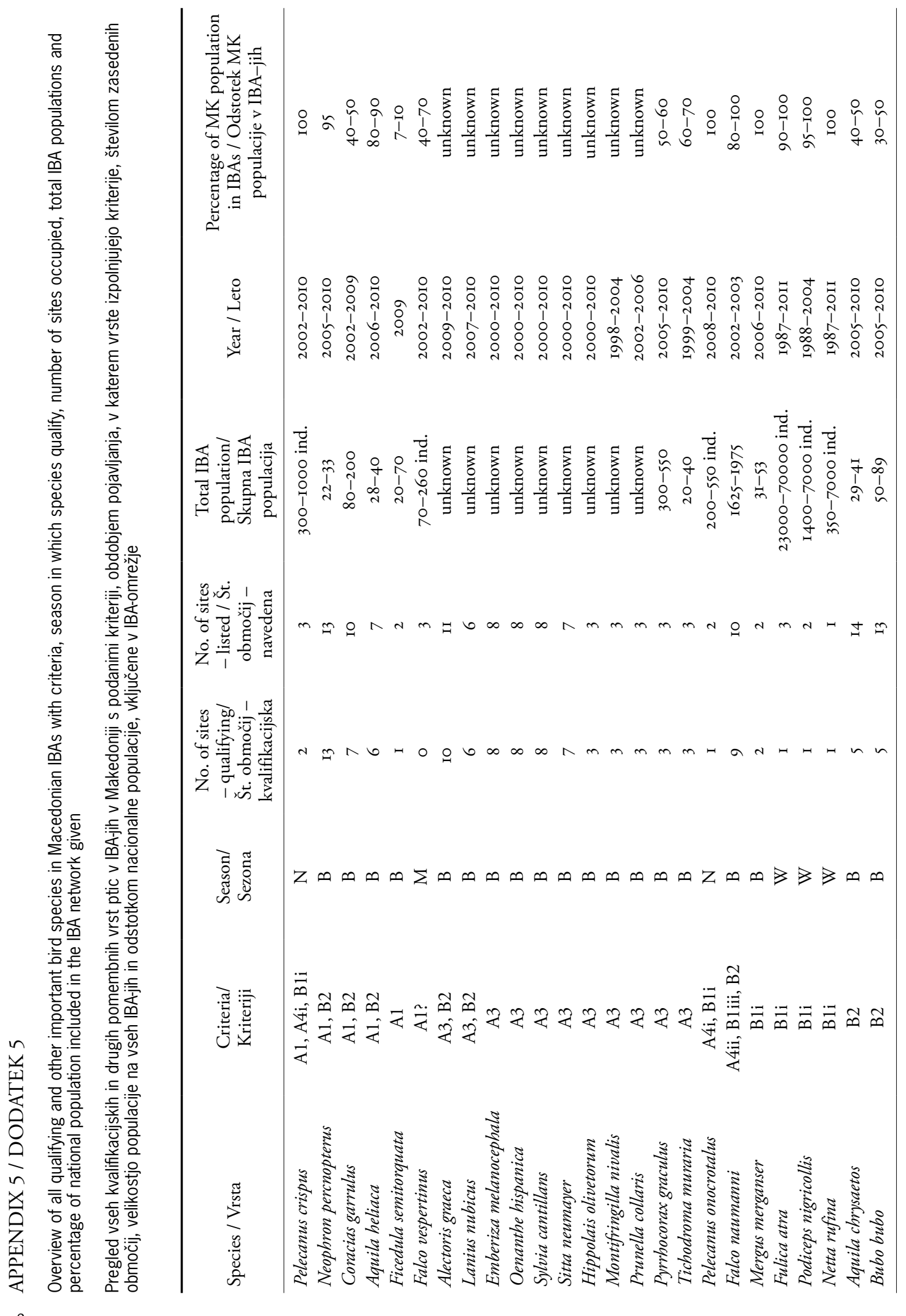




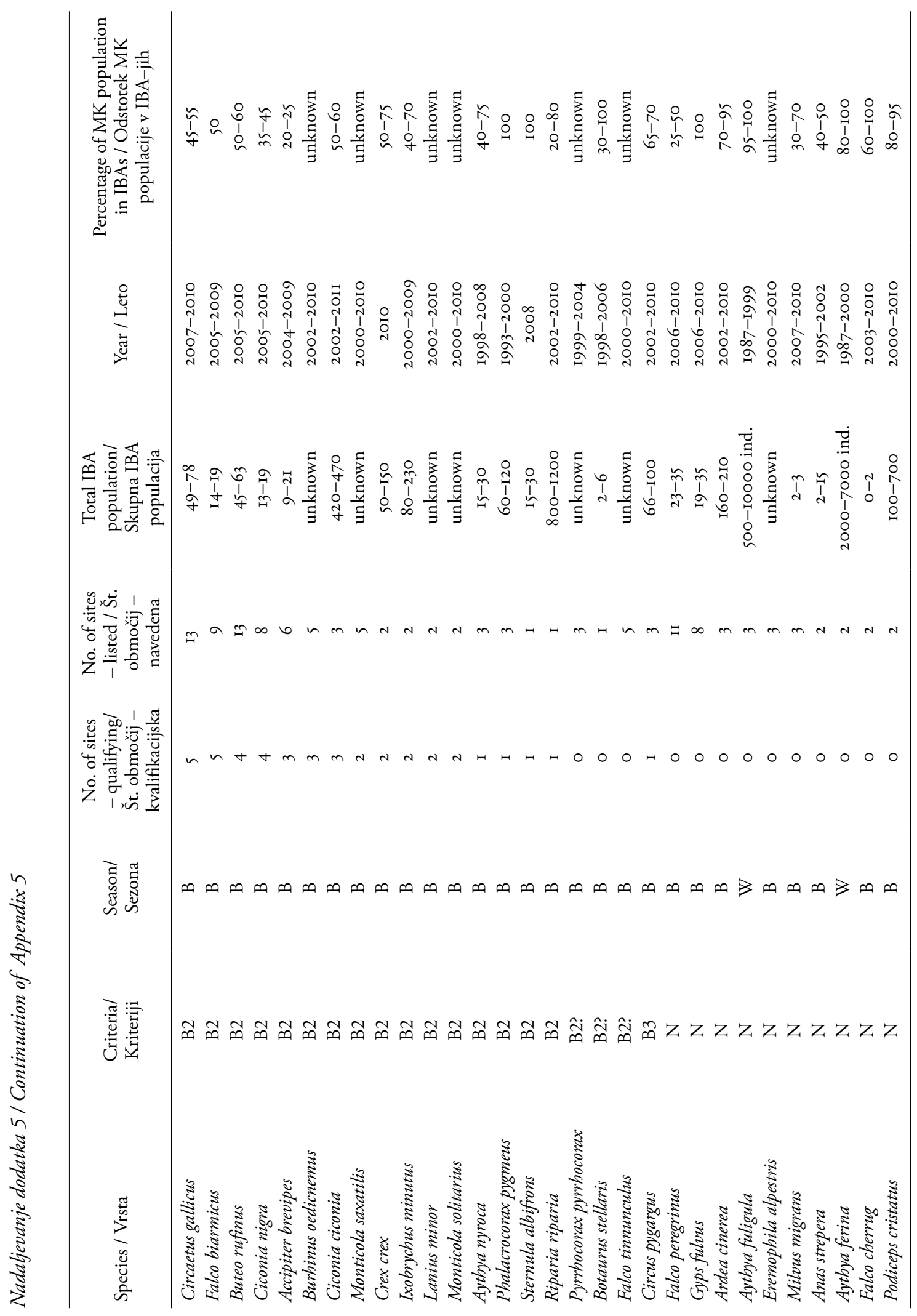


M. Velevski, B. Hallmann, B. Grubač, T. Lisičanec, E. Stoynov, E. Lisičanec, V. Avukatov, L. Božič \& B. Stumberger: Important Bird Areas in Macedonia: Sites of Global and European Importance

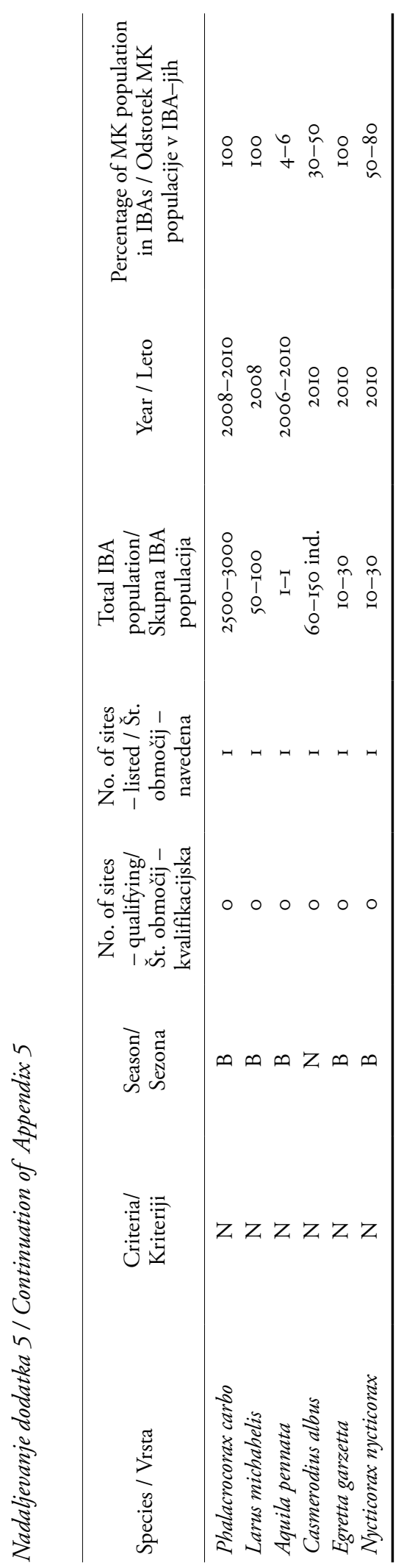

